\title{
Membership in international organizations: inequality among equals
}

Citation for published version (APA):

Memeti, A. (2013). Membership in international organizations: inequality among equals. [Doctoral Thesis, Maastricht University]. Datawyse / Universitaire Pers Maastricht. https://doi.org/10.26481/dis.20131113am

Document status and date:

Published: 01/01/2013

DOI:

10.26481/dis.20131113am

Document Version:

Publisher's PDF, also known as Version of record

\section{Please check the document version of this publication:}

- A submitted manuscript is the version of the article upon submission and before peer-review. There can be important differences between the submitted version and the official published version of record.

People interested in the research are advised to contact the author for the final version of the publication, or visit the DOI to the publisher's website.

- The final author version and the galley proof are versions of the publication after peer review.

- The final published version features the final layout of the paper including the volume, issue and page numbers.

Link to publication

\footnotetext{
General rights rights.

- You may freely distribute the URL identifying the publication in the public portal. please follow below link for the End User Agreement:

www.umlib.nl/taverne-license

Take down policy

If you believe that this document breaches copyright please contact us at:

repository@maastrichtuniversity.nl

providing details and we will investigate your claim.
}

Copyright and moral rights for the publications made accessible in the public portal are retained by the authors and/or other copyright owners and it is a condition of accessing publications that users recognise and abide by the legal requirements associated with these

- Users may download and print one copy of any publication from the public portal for the purpose of private study or research.

- You may not further distribute the material or use it for any profit-making activity or commercial gain

If the publication is distributed under the terms of Article $25 \mathrm{fa}$ of the Dutch Copyright Act, indicated by the "Taverne" license above, 
MEMBERSHIP IN INTERNATIONAL ORGANIZATIONS:

INEQUALITY AMONG EQUALS 
(C) Copyright Ardit Memeti, Maastricht 2013

Production: Datawyse | Universitaire Pers Maastricht

ISBN 9789461592750 


\title{
MEMBERSHIP IN INTERNATIONAL ORGANIZATIONS: INEQUALITY AMONG EQUALS
}

\author{
DISSERTATION \\ to obtain the degree of Doctor at Maastricht University, \\ on the authority of the Rector Magnificus, Prof. dr. L.L.G Soete \\ in accordance with the decision of the Board of Deans, \\ to be defended in public on Wednesday, 13 November 2013, at 12:00 hours \\ by \\ Ardit Memeti
}




\section{Supervisor}

Prof. dr. Peter L.H. Van den Bossche

\section{Assessment Committee}

Prof. dr. Menno Kamminga (Chairman)

Assoc. Prof. dr. Denise Prevost

Prof. dr. Elena Andreevska (South East European University, Tetovo, R. Macedonia)

This doctoral research benefited from the financial assistance of the Netherlands Fellowship Programme of NUFFIC. 
This book is dedicated to my wife Nora and to my son Gent. Maastricht, October 2013 


\section{ACKNOWLEDGMENTS}

First and foremost I would like to thank my thesis supervisor Prof. dr. Peter L.H. Van den Bossche to whom I am eternally grateful for his guidance, support and time. For the five and a half years I have spent writing this book, he has provided continuous intellectual support for a topic which has proved to be interesting and dynamic as well as complex and simple at the same time. I also thank the members of the doctoral assessment committee, Prof. dr. Menno Kamminga (Chairman), Assoc. Prof. dr. Denise Prevost and Prof. dr. Elena Andreevska for reading and commenting on the manuscript. I have benefited from their insightful comments from which I have drawn important intellectual inspiration.

This book would have not been possible without the financial support of NUFFIC, which through the Netherlands Fellowship Programme of the Ministry of Foreign Affairs has covered all the costs related to my PhD studies at the Faculty of Law of Maastricht University, for which I'm very grateful. In particular, I would like to thank Diana Schabregs, the Financial \& (Contract) Research Manager of the Faculty of Law of Maastricht University for her kind assistance and the management of the NUFFIC grant through the years.

For his time spent proofreading this book and for his valuable support through the years I thank Prof. Andrew Goodspeed, SEEU Provost, professor of the Faculty of Languages, Cultures and Communication. I also thank Doc. Dr. Agron Rustemi from the SEEU Faculty of Public Administration for his generous assistance in developing around thirty tables and charts throughout book.

Finally, I would like to thank my family for being by my side during these challenging and yet fruitful years. I'm grateful to my parents, Sait and Rabije, who have raised me with unconditional love for knowledge and education and my brother Memet for his continuous inspiration and support for the successful completion of this book.

Most of all, I thank my wife Nora and my son Gent. Their love and patience have been the energy that has kept me going during all the challenges I have faced while writing this book. They have eased the burden of writing this book by their sheer existence in my life. 


\section{SUMMARY}

The principle of equality of states originated from the municipal law ideal and legal principle of equality of men which, by analogy, transformed into the legal principle of equality of states in international law. As a principle of international law, the principle of equality of states applies to the law of international organizations, as the latter is a branch of international law. In international organizations, the principle of equality of states evolved through international conferences which adopted unanimity decisionmaking and the principle of one-state one-vote. Over time, the principle became part of the constitutions of international organizations. Before World War II, the principle of equality of states was present through the unanimity rule in the Covenant of the League of Nations and the equality of voting powers and representation in the Assembly. After World War II, the principle of equality of states became part of the UN Charter.

The aim of this book is to explore the meaning, the role, and the application of the principle of equality of states in international organizations (IGOs). The question of whether or not the principle of equality of states is applied in international organizations is important. The (non)application of the principle of equality of states influences state behavior, inclusiveness, effectiveness and the will of states to participate fully in the efficient functioning of any international organization.

According to the principle of equality of states, regardless of their differences, all states are considered to be equal in international law. The fact that there are overwhelming differences between states does not make the application of the principle of equality of states in international organizations easy, or at times, viable and realistic. Therefore, the application of the principle of equality of states in international organizations is, and will most probably remain, a continuous challenge for states and international organizations. As Kooijmans noted, equality is a mathematical notion which when drawn into the legal sphere results in a doctrine at odds with reality which by necessity involves opposition.

While it is clear that the principle of equality of states in IGOs requires equality in rights and obligations of states, the difficulty in reviewing the application of the principle of equality of states in IGOs is to find out how much states are equal in their rights and duties in international organizations. Due to the fact that the principle of equality of states is an "umbrella" type of principle, it covers a wide range of matters. Therefore, the review of its application in international organizations requires a comprehensive approach that would include a number of important aspects. The discussion on the application of the principle of equality of states in international organizations includes 
the following sets of questions: 1. acquisition of membership; 2. the rights and duties of members; and 3. the processes limiting or terminating membership rights (suspension, expulsion and withdrawal of membership).

Having in mind that there are hundreds of international organizations with various membership policies, any endeavor of this nature cannot possibly cover all of them as, even if research is limited to the most important international organizations, no scholar can cover on his own the field of law. In such a variety of hundreds of international organizations, there can always be reasons for including or excluding certain international organizations.

The selection criteria of the international organizations discussed in this book are based, first, on the relevance of the international organizations in question, and second, more importantly, whether they represent an important model of the application of the principle of equality of states. Having said this, due to the reasons explained in this section, and throughout this book, the application of the principle of equality of states will be reviewed in the following three international organizations: the United Nations, the World Trade Organization, and the International Monetary Fund. Each of these international organizations is important and relevant and, as such, represents a principle model of how the principle of equality of states is applied in international organizations.

In terms of the structure of the book, the evolution and the meaning of the principle of equality of states from municipal law to international law will be discussed in Chapter I; the evolution and the meaning of the principle of equality of states in international organizations will be discussed in Chapter II; and the relevant aspects for review of the principle of equality of states in international organizations are discussed in Chapter III. The application of the principle of equality of states in the United Nations is discussed in Chapter IV; the application of the principle of equality of states in the World Trade Organization is discussed in Chapter V; and the application of the principle of equality of states in the International Monetary Fund is discussed in Chapter VI. Finally, Chapter VII provides for general conclusions on the principle of equality of states in international organizations as well as specific conclusions applicable to the UN, WTO and the IMF. 


\section{LIST OF ABBREVIATIONS}

\begin{tabular}{|c|c|}
\hline $\mathrm{AB}$ & Appellate Body (WTO) \\
\hline ACWL & Advisory Centre on WTO Law \\
\hline Am. Econ. Rev. & American Economic Review \\
\hline Am. J. Int'l. L. & American Journal of International Law \\
\hline Am. Pol. Sci. Rev. & American Political Science Review \\
\hline ASEAN & Association of Southeast Asian Nations \\
\hline AU & African Union \\
\hline Aust. YBIL & Australian Yearbook of International Law \\
\hline BRIC & Brazil, Russia, India and China \\
\hline Brit. Y. B. Int'l. L. & British Yearbook of International Law \\
\hline Brook. J. Int’l. L. & Brooklyn Journal of International Law \\
\hline Chi. J. Int'l. L. & Chicago Journal of International Law \\
\hline China L. Rev. & China Law Review \\
\hline $\mathrm{CoE}$ & Council of Europe \\
\hline Colum. L. Rev. & Columbia Law Review \\
\hline Cornell Int’l. L. J. & Cornell International Law Journal \\
\hline CSCE & Conference on Security and Cooperation in Europe \\
\hline DSB & Dispute Settlement Body (WTO) \\
\hline ECOSOC & Economic and Social Council (UN) \\
\hline EDC & European Defense Community \\
\hline EFTA & European Free Trade Association \\
\hline ESA & European Space Agency \\
\hline EU & European Union \\
\hline Eur. J. Int. L. & European Journal of International Law \\
\hline FAO & Food and Agriculture Organization \\
\hline GA & General Assembly (UN) \\
\hline GATS & General Agreement on Trade in Services \\
\hline GATT & General Agreement on Trade and Tariffs \\
\hline GDP & Gross Domestic Product \\
\hline GNP & Gross National Product \\
\hline Harv. Int’l. L. J. & Harvard International Law Journal \\
\hline Harv. L. Rev. & Harvard Law Review \\
\hline Howard L. J. & Howard Law Journal \\
\hline IBIP & International Bureau of Industrial Property \\
\hline
\end{tabular}


International Bank for Reconstruction and Development

ICC International Criminal Court

ICJ International Court of Justice

IDA International Development Association

IFC International Finance Corporation

IGO International Governmental Organization

IGOs International Governmental Organizations

IIA International Institute of Agriculture

ILC International Law Commission

ILO International Labor Organization

IMF International Monetary Fund

Int'l. Comp. L. Quart. International and Comparative Law Quarterly Int'l. L. Quart. International Law Quarterly Int'l. Org. L. Rev. International Organisations Law Review Int'l. Org. International Organization $\mathrm{IO}$ International Organization

IOM

ITO International Organization for Migration

International Trade Organization

J. Int'l. Econ. L. Journal of International Economic Law

J. Legal. Stud. Journal of Legal Studies

LDC Least-Developed Country (WTO)

LN League of Nations

MFN Most Favoured Nation Treatment (WTO)

Mich. L. Rev. Michigan Law Review

MIGA Multilateral Investment Guarantee Agency

NAFTA North American Free Trade Area

NATO North Atlantic Treaty Organization

Neth. YBIL Netherlands Yearbook of International Law

NGO Non Governmental Organization

Nordic J. Int'l. L. Nordic Journal of International Law

NT

OAPEX

National Treatment (WTO)

OAS

Organization of Arab Petroleum Exporting Countries

OAU

Organization of American States

OECD

Organization of African Unity

OPEC

Organization for Economic Co-operation and Development

OSCE

Organization for Petroleum Exporting Countries

PCIJ

Organization for Security and Co-operation in Europe

Polit. Sci. Quart. Permanent Court of International Justice

Popul. Dev. Rev. Political Science Quarterly

QUAD Population and Development Review US, Japan, Canada, EU 


\begin{tabular}{|c|c|}
\hline Rev. Int'l. Stud. & Review of International Studies \\
\hline SC & Security Council (UN) \\
\hline SG & Secretary-General (UN) \\
\hline Stan. L. Rev. & Stanford Law Review \\
\hline T. Jefferson L. Rev. & Thomas Jefferson Law Review \\
\hline TPRM & Trade Policy Review Mechanism (WTO) \\
\hline TRIPS & Trade Related Aspects of Intellectual Property (WTO) \\
\hline UK & United Kingdom \\
\hline UN & United Nations \\
\hline UNCTAD & United Nations Conference on Trade and Employment \\
\hline UNCTAD & United Nations Conference on Trade and Development \\
\hline UNDP & United Nations Development Programme \\
\hline UNESCO & United Nations Educational Scientific and Cultural Organization \\
\hline UNIDO & United Nations Industrial Development Organization \\
\hline UPU & Universal Postal Union \\
\hline US & United States \\
\hline USSR & Union of Soviet Socialist Republics \\
\hline Va. J. Int'l. L. & Virginia Journal of International Law \\
\hline Va. L. Rev. & Virginia Law Review \\
\hline VCLT & Vienna Convention on the Law of Treaties \\
\hline WB & World Bank \\
\hline WHO & World Health Organization \\
\hline WMO & World Meteorological Organization \\
\hline WP & Working Party (WTO) \\
\hline WTO & World Tourism Organization \\
\hline WTO & World Trade Organization \\
\hline WW & World War \\
\hline Yale L. J. & Yale Law Journal \\
\hline YBILC & Yearbook of the International Law Commission \\
\hline
\end{tabular}




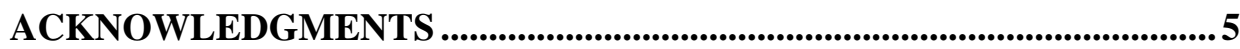

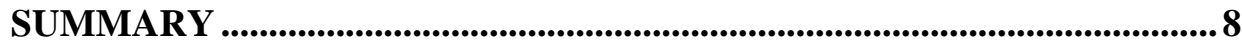

LIST OF ABBREVIATIONS ........................................................................... 10



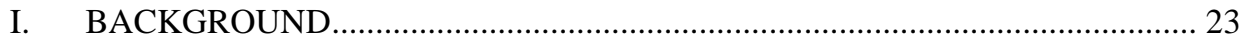

II. RESEARCH QUESTIONS AND METHODOLOGY …………………............. 25

III. SOCIETAL AND SCIENTIFIC RELEVANCE …………………..................... 28

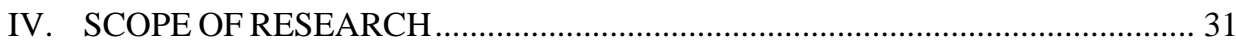

\section{CHAPTER I THE EVOLUTION OF THE PRINCIPLE OF} EQUALITY OF STATES IN INTERNATIONAL LAW .............................33

I. INTRODUCTION.......................................................................................... 33

II. THE MUNICIPAL LAW ORIGINS OF THE PRINCIPLE OF EQUALITY OF

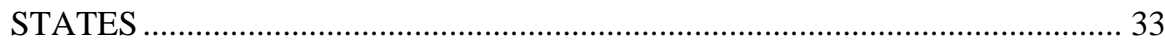

III. THE TRANSFORMATION OF THE PRINCIPLE OF EQUALITY OF MEN INTO THE PRINCIPLE OF EQUALITY OF STATES ....................................... 36

IV. THE PRINCIPLE OF EQUALITY OF STATES IN INTERNATIONAL LAW .. 38

V. THE PRINCIPLE OF EQUALITY OF STATES, A JUS COGENS NORM OF



VI. THE PRINCIPLE OF EQUALITY OF STATES: NON-DISCRIMINATION

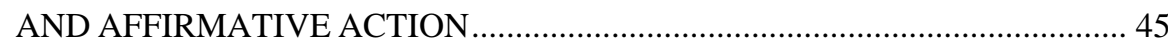

VII. THE MEANING OF THE PRINCIPLE OF EQUALITY OF STATES IN

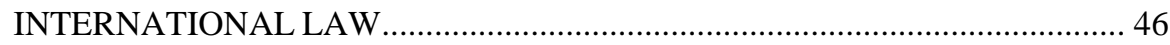

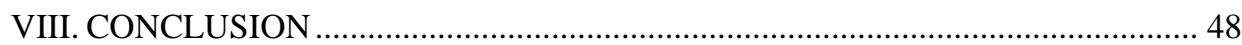

CHAPTER II THE PRINCIPLE OF EQUALITY OF STATES IN INTERNATIONAL ORGANIZATIONS ...............................................50

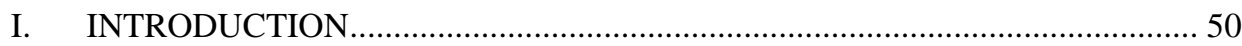


II. INTERNATIONAL ORGANIZATIONS AND THE PRINCIPLE OF EQUALITY OF STATES

III. MEMBER STATES AND INTERNATIONAL ORGANIZATIONS.

IV. THE EVOLUTION OF THE PRINCIPLE OF EQUALITY OF STATES: FROM INTERNATIONAL CONFERENCES TO THE LEAGUE OF NATIONS

V. THE PRINCIPLE OF EQUALITY OF STATES BEYOND THE LEAGUE OF NATIONS

VI. THE PRINCIPLE OF EQUALITY OF STATES IN INTERNATIONAL ORGANIZATIONS: A CONSTITUTIONAL OBLIGATION FOR STATES ..... 62

VII. THE MEANING OF THE PRINCIPLE OF EQUALITY OF STATES IN INTERNATIONAL ORGANIZATIONS

VIII. CRITICISM TO THE PRINCIPLE OF EQUALITY OF STATES IN INTERNATIONAL LAW AND INTERNATIONAL ORGANIZATIONS ......... 65

IX. CONCLUSION.... 68

\section{CHAPTER III THE REVIEW OF THE PRINCIPLE OF EQUALITY OF STATES IN INTERNATIONAL} ORGANIZATIONS 71

I. INTRODUCTION 71

II. THE FOUNDING TREATIES OF INTERNATIONAL ORGANIZATIONS AND THE PRINCIPLE OF EQUALITY OF STATES. .73

III. ACQUISITION OF MEMBERSHIP IN INTERNATIONAL ORGANIZATIONS AND THE PRINCIPLE OF EQUALITY OF STATES........ 73

1. THE NEGOTIATIONS FOR THE ESTABLISHMENT OF INTERNATIONAL ORGANIZATIONS AND ORIGINAL MEMBERSHIP ..... 74

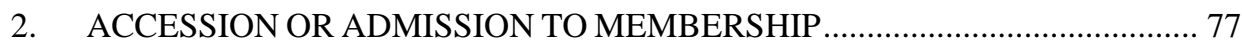

IV. THE PRINCIPLE OF EQUALITY OF STATES IN THE DECISIONMAKING OF INTERNATIONAL ORGANIZATIONS .................................... 79

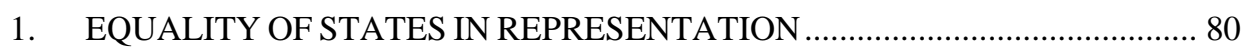

2. EQUALITY OF STATES IN DECISION-MAKING PROCESSES: UNANIMITY, MAJORITY AND CONSENSUAL DECISION-MAKING ........ 82

3. VOTING POWERS AND EQUALITY OF STATES ........................................ 87

V. THE PRINCIPLE OF EQUALITY OF STATES IN FINANCING INTERNATIONAL ORGANIZATIONS ........................................................ 98

VI. THE PRINCIPLE OF EQUALITY OF STATES IN SUSPENSION, EXPULSION AND WITHDRAWAL OF MEMBERSHIP

VII. CONCLUSION 


\section{CHAPTER IV THE PRINCIPLE OF EQUALITY OF STATES IN}

THE UNITED NATIONS

I. INTRODUCTION 104

II. THE PRINCIPLE OF EQUALITY OF STATES IN THE UNITED NATIONS CHARTER 106

III. ACQUISITION OF MEMBERSHIP IN THE UNITED NATIONS ......................109

1. THE PRINCIPLE OF EQUALITY OF STATES IN THE NEGOTIATIONS FOR THE ESTABLISHMENT OF THE UNITED NATIONS.............................111

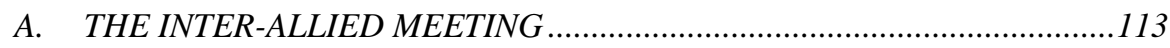

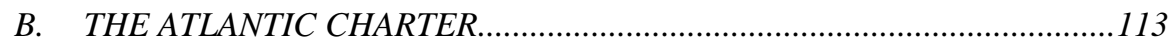

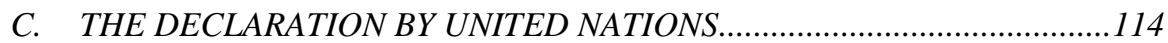

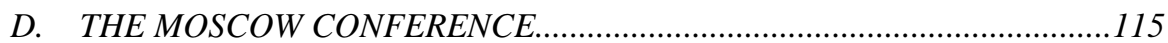

E. THE TEHERAN CONFERENCE ……………....................................116

F. THE DUMBARTON OAKS CONFERENCE............................................117

G. THE YALTA CONFERENCE …………………………...........................118

H. THE SAN FRANCISCO CONFERENCE ....................................................119

2. ORIGINAL MEMBERS AND THE APPLICATION OF THE PRINCIPLE OF

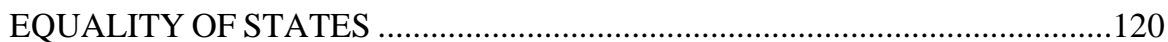

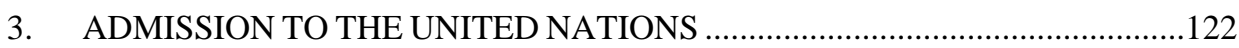

3.1 SUBSTANTIVE LAW ON ADMISSION …………………………………....123

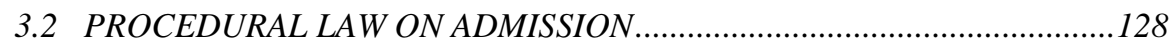

4. ACQUISITION OF MEMBERSHIP IN THE UNITED NATIONS AND THE PRINCIPLE OF EQUALITY OF STATES.....................................................131

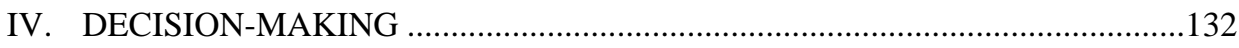

1. THE SECURITY COUNCIL ........................................................................132

1.1 LIMITED MEMBERSHIP RESULTING IN LIMITED EQUALITY ..............133

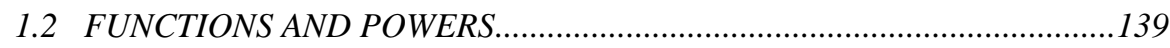

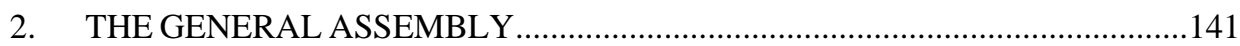

3. EQUALITY OF STATES AND THE DUALISM BETWEEN THE GENERAL ASSEMBLY AND THE SECURITY COUNCIL .............................................144

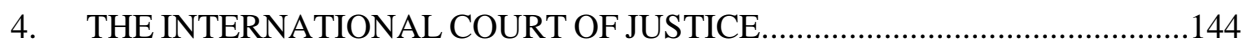

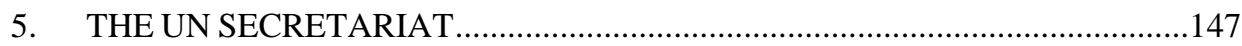

6. UN REFORM AND THE PRINCIPLE OF EQUALITY OF STATES .................151

7. DECISION-MAKING AND THE PRINCIPLE OF EQUALITY OF STATES

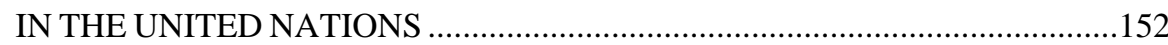

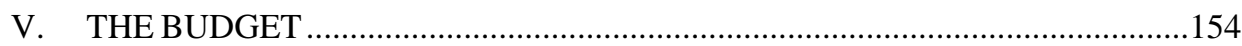

VI. SUSPENSION, EXPULSION OR WITHDRAWAL OF MEMBERS IN THE

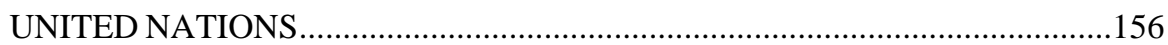

1. SUSPENSION OF MEMBERSHIP ………………………...............................157

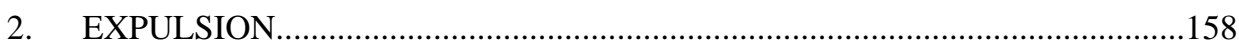


3. IS THERE A RIGHT TO WITHDRAW FROM THE UNITED NATIONS? .......158

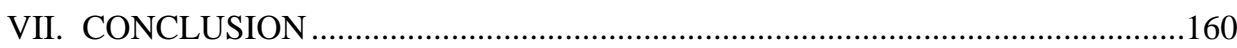

\section{CHAPTER V THE PRINCIPLE OF EQUALITY OF STATES IN} THE WORLD TRADE ORGANIZATION ...................................................... 162

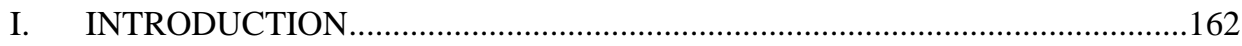

II. THE PRINCIPLE OF EQUALITY OF STATES IN THE WTO AGREEMENT.165

III. ACQUISITION OF MEMBERSHIP IN THE WTO …………………………......168

1. THE PRINCIPLE OF EQUALITY OF STATES IN THE NEGOTIATIONS FOR THE ESTABLISHMENT OF THE WTO....................................................169

A. THE BRETTON WOODS CONFERENCE ………..................................171

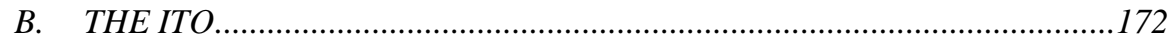

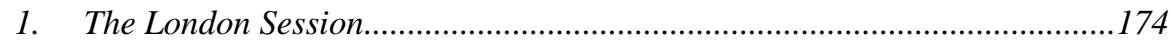

2. The New York Lake Success Meeting ..........................................................174

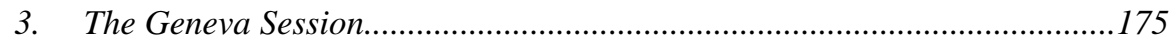

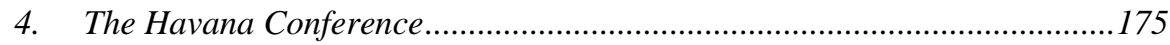

5. The principle of equality of states and the Havana Charter ..........................176

C. THE GATT 1947 ..................................................................................

2. ORIGINAL MEMBERS AND THE APPLICATION OF THE PRINCIPLE OF

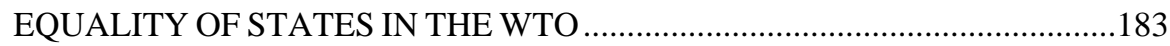

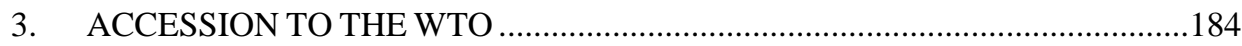

3.1 SUBSTANTIVE LAW ON ACCESSION ……………………………........185

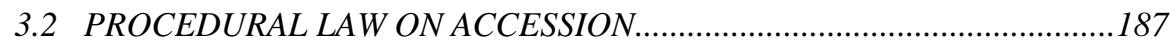

3.3 ACCESSION OF LEAST DEVELOPED COUNTRIES TO THE WTO.........188

4. ACQUISITION OF MEMBERSHIP IN THE WTO AND THE PRINCIPLE OF

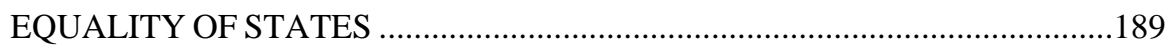

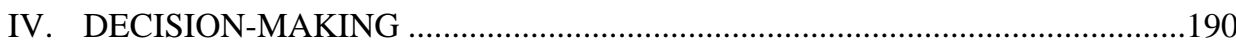

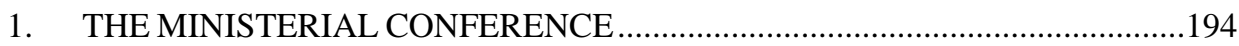

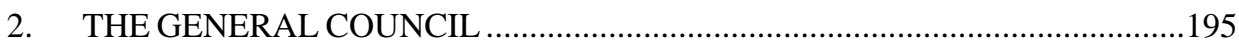

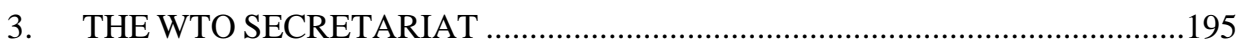

4. THE WTO DISPUTE SETTLEMENT SYSTEM ……...........................................198

5. WTO REFORM AND THE PRINCIPLE OF EQUALITY OF STATES..............201

6. DECISION-MAKING AND THE PRINICPLE OF EQUALITY OF STATES

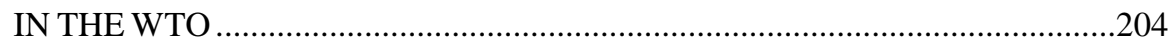

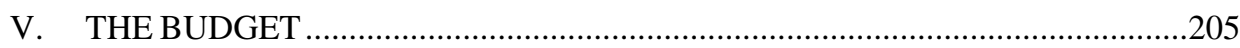

VI. SUSPENSION, EXPULSION, AND WITHDRAWAL OF MEMBERS IN THE

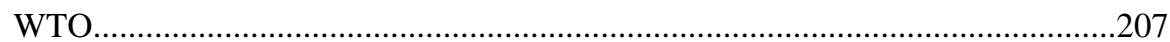

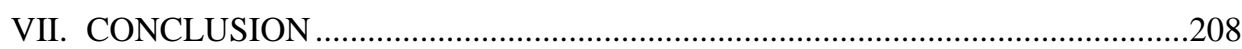




\section{CHAPTER VI THE PRINCIPLE OF EQUALITY OF STATES IN}

THE INTERNATIONAL MONETARY FUND

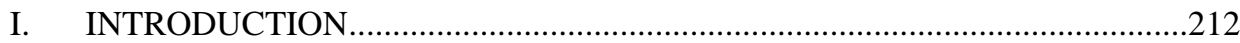

II. THE IMF ARTICLES OF AGREEMENT AND THE PRINCIPLE OF EQUALITY OF STATES

III. ACQUISITION OF MEMBERSHIP IN THE IMF ………….............................217

1. THE PRINCIPLE OF EQUALITY OF STATES IN THE NEGOTIATIONS FOR THE ESTABLISHMENT OF THE IMF...................................................218

A. PRE BRETTON WOODS NEGOTIATIONS ….......................................219

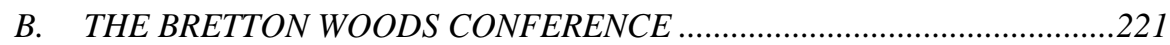

2. ORIGINAL MEMBERS OF THE IMF AND THE PRINCIPLE OF

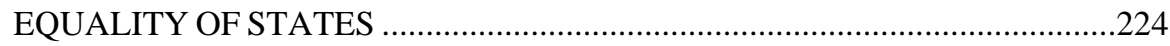

3. ADMISSION OF NEW MEMBERS TO THE IMF ..............................................226

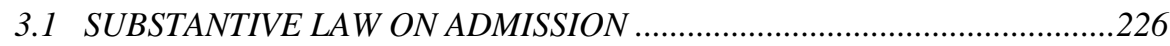

3.2 PROCEDURAL LAW ON ADMISSION ........................................................228

4. ACQUISITION OF MEMBERSHIP IN THE IMF AND THE PRINCIPLE OF

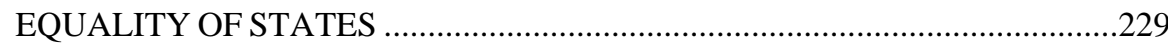

IV. DECISION-MAKING IN THE IMF …………………........................................231

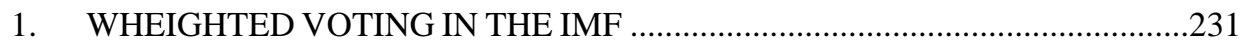

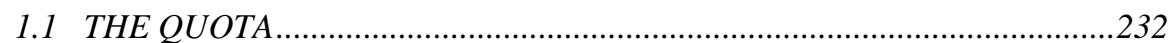

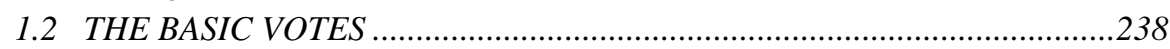

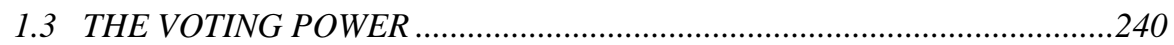

2. MAJORITY AND CONSENSUS DECISION-MAKING IN THE IMF ...............247

2.1 MAJORITY DECISION-MAKING IN THE IMF ……..................................247

2.2 CONSENSUS DECISION-MAKING IN THE IMF …..................................249

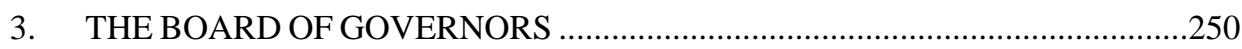

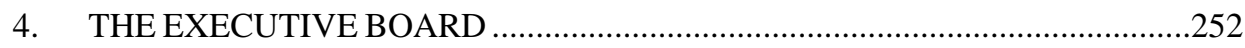

5. THE MANAGING DIRECTOR AND THE STAFF ..............................................25

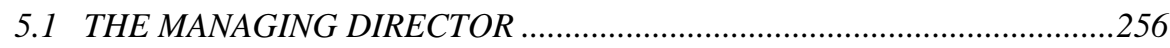

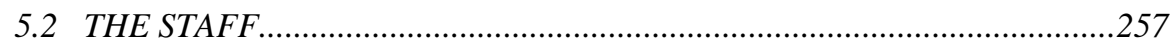

6. IMF REFORM AND THE PRINCIPLE OF EQUALITY OF STATES................260

7. DECISION-MAKING AND THE PRINCIPLE OF EQUALITY OF STATES

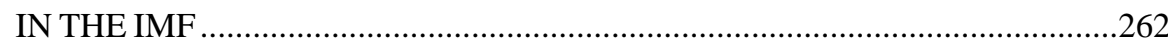



VI. SUSPENSION, EXPULSION AND WITHDRAWAL OF MEMBERS IN THE

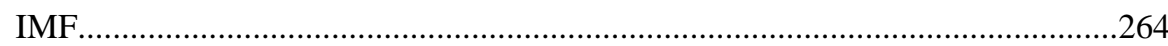

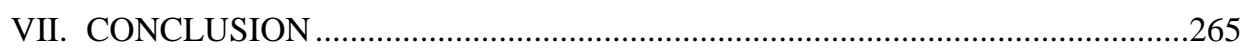

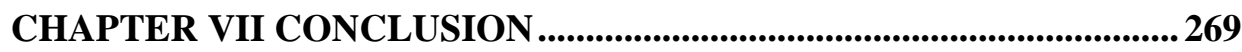




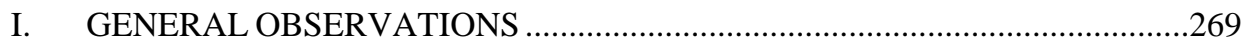

II. THE REVIEW OF THE PRINCIPLE OF EQUALITY OF STATES IN



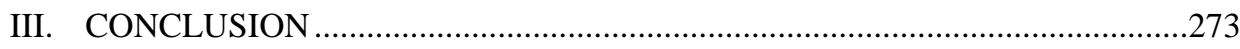

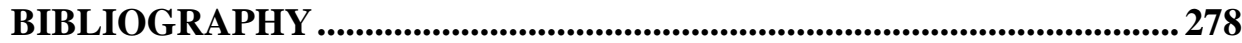

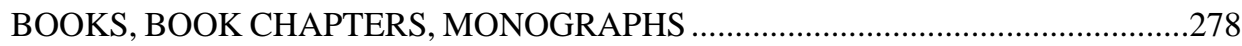

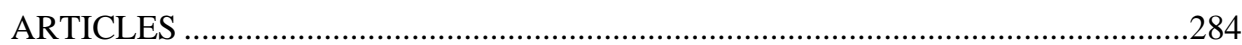

INTERNATIONAL AND MUNICIPAL LEGAL INSTRUMENTS, REPORTS,

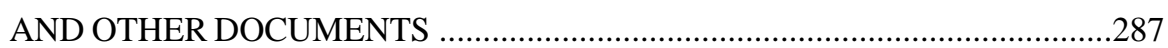

TABLE OF CASES- INTERNATIONAL AND NATIONAL .......................291

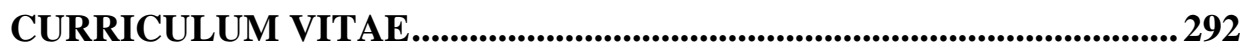




\section{LIST OF TABLES AND CHARTS}

Table 1: The 20 most populous states of the world................................................... 90

Table 2: The 20 states of the world with the highest GDP........................................ 93

Table 3: The 20 largest states of the world by territory …………………………..... 95

Table 4: The 20 states representing the world largest share of GDP, population, and size of territory ................................................................. 97

Table 5: Share of quota according to the Schedule A of the Articles of Agreement.............................................................................................223

Table 6: Quota share and voting power of the 10 largest and the remaining 34 IMF members in 1947 ..........................................................................232

Table 7: The changes of the total quota shares in the IMF.....................................234

Table 8: Quota share of IMF members in \% ......................................................235

Table 9: Quota shares of EU member states in the IMF .........................................237

Table 10: The $\%$ of votes of individual IMF members ...............................................242

Table 11: The number and \% of votes of EU member states in the IMF ....................246

Table 12: The 24 executive directors of the executive board and their voting powers ................................................................................................253

Table 13: IMF staff nationality by region, country and total staff (excluding the office of executive directors) as of April 30, 2012.....................................258

Chart 1: Share of world population between the 20 most populous states and the remaining 173 states

Chart 2: Share of world GDP between the 20 states representing the largest economies of the world and the remaining 173 states.

Chart 3: Size of territory between the 20 largest states and the remaining 173

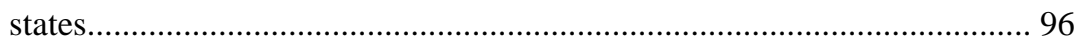

Chart 4: Increase in UN membership through the years ..........................................111

Chart 5: The representation of UN Members in the Security Council as nonpermanent members

Chart 6: United Nations Secretary-Generals by nationalityError! Bookmark not defined.

Chart 7: The share of the 10 largest UN contributors and the remaining 183 UN Members.

Chart 8: The evolution from GATT Contracting Parties to WTO Members ............169

Chart 9: Overview of WTO Secretariat by nationality ...............................................197

Chart 10: Share of WTO Members participation in the WTO budget .........................207

Chart 11: Increase of IMF membership through the years..........................................217

Chart 12: A comparison in quota shares and voting power between the 10 largest members and the remaining 34 in \% .233 
Chart 13: The \% of basic votes in the total votes of the IMF.

Chart 14: IMF Managing Directors by nationality....

Chart 15: Staff representation and quota share difference between developing and industrial countries

Chart 16: Changes in the quota shares..... 


\section{INTRODUCTION}

\section{BACKGROUND}

There are around seven billion people living in almost 200 states in the world today. ${ }^{1}$ The most populous states such as China and India combined have a population of around 2.5 billion people, and the least populous states such as Tuvalu and Nauru combined have a population of around twenty thousand people. Population size is not the only disparity between states. States are also different with regard to their GDP, the size of their territory, economic and military power, technology and education and many other parameters. ${ }^{2}$ To make things even more unpredictable, many (if not all) of these differences between states are not static; on the contrary, they are rather dynamic and tend to change over time.

According to the principle of equality of states, regardless of their differences, all states are considered to be equal in international law.

The principle of equality of states originated from the municipal law ideal and legal principle of equality of men which, by analogy, transformed into the legal principle of equality of states in international law. In legal doctrine authors such as Oppenheim, Brownlie, Cassese, and Shaw consider the principle of equality of states as one of the most important principles of international law. For Oppenheim the principle of equality of states represents the "indispensable foundation of international society"3, to Brownlie this principle represents the "basic constitutional doctrine of the law of nations", Cassese considers it "the linchpin of the whole body of international legal standards, the fundamental premise on which all international relations rest" ${ }^{\text {, }}$, and Shaw considers it to

\footnotetext{
${ }^{1}$ For example, the United Nations has 193 Member States. For data on world population see United Nations Population Division, Department of Economic and Social Affairs, World Population Prospects: The 2010 Revision, POP/DB/WPP/Rev.2010/02/F01, New York, 2011.

${ }^{2}$ If for example, a distinction is made between the 20 UN Members that have the largest \% of the world population, GDP and territory and the remaining 173 out of the 193 UN Members, estimates show that a majority of 173 UN Members having 173 votes or $89.63 \%$ of the total votes (out of the 193 in total), represent "only" $29 \%$ of the world population, $19.1 \%$ of world GDP and $32.71 \%$ of the territory of states per sq. km. The remaining $20 \mathrm{UN}$ Members having 20 votes or $10.36 \%$ of the total votes represent: $71 \%$ of the world population, $80.9 \%$ of world GDP and $67.29 \%$ of the territory of states per sq. $\mathrm{km}$. For a more detailed discussion on the disparities between states with regard to population size, GDP and territory see below, Chapter III, pg. 101-114.

${ }^{3}$ L. Oppenheim, The Future of International Law, Carnegie Endowment for International Peace, Pamphlet No. 39, 1921, pg. 20.

${ }^{4}$ Ian Brownlie, Principles of International Law, Fourth Edition, Oxford University Press, 1990, pg. 287.

${ }^{5}$ Antonio Cassese, International Law, Second Edition, Oxford University Press, 2005, pg. 46.
} 
be a "crucial principle" ${ }^{\prime 6}$ of international law. The principle of equality of states as a principle of international law applies to the law of international organizations, as the latter is a branch of international law.

The aim of this book is to explore the meaning, the role, and the application of the principle of equality of states in international organizations (IGOs). ${ }^{7}$ The question whether or not the principle of equality of states is applied in international organizations is important. The (non)application of the principle of equality of states influences state behavior, inclusiveness, effectiveness and the will of states to participate fully in the efficient functioning of any international organization.

The evolution of the principle of equality of states and its application in international organizations was accompanied by the constant increase in the numbers of states and international organizations to whom the principle applies. There were around 50 acknowledged states at the beginning of the XX century, around 75 before World War II, and now at the beginning of the XXI century, almost $200{ }^{8}$ This means that the number of states has increased by around 300\% since the beginning of the XX century. On the other hand, the number of international organizations has also increased immensely during the last century. According to the Yearbook of International Organizations, in 1909 there were 37 international organizations, in 1964 there were 174 international organizations, and by 2011 the number of international organizations has increased to around $1536 .^{9}$

States are independent, and yet interdependent units of power. ${ }^{10}$ Their interdependency is perhaps best reflected in the need to establish international organizations and transfer some of their sovereignty to them. International organizations represent separate legal entities that are established, function, and may be terminated by their members. They are established by at least three members to make sure that in case one

\footnotetext{
${ }^{6}$ Malcolm N. Shaw, International Law, Sixth Edition, Cambridge University Press, 2008, pg. 214.

${ }^{7}$ The term "international organization" for the purpose of this book refers only to international governmental organizations and excludes nongovernmental international organizations. This is in line with the Vienna Convention on the Law of Treaties of 1969, Article 2, paragraph 1, (i), and the Vienna Convention on the Representation of States in their Relations with International Organizations of a Universal Character, 1975, Article 1, paragraph 1, (1), both stating that by "international organization” they mean an "intergovernmental organization.

${ }^{8}$ James R. Crawford, The Creation of States in International Law, Second Edition, Oxford University Press, 2007, pg. 4.

9 Jeffrey L. Dunoff, Is Sovereign Equality Obsolete? Understanding Twenty-First Century International Organizations, 43 Neth. YBIL 99 (2013), pg. 107. It should be noted that there is no clear understanding on the exact number of IGOs. According to Amerashinghe, there are 7080 IGOs, out of these 232 are 'conventional' organizations (35 universal and 197 regional), see C. F. Amerasinghe, Principles of the Institutional Law of International Organizations, Second Edition, Cambridge University Press, 2005, pg. 6, footnote 10. According to another study, there were 263 international organizations in 1994 and 247 in 2008, see Alison Duxbury, The Participation of States in International Organizations, the Role of Human Rights and Democracy, Cambridge University Press, 2011, pg. 15. On the other hand, the 2009 edition of Bowett's Law of International Institutions notes that there are 1,839 intergovernmental organizations, see Philippe Sands and Pierre Klein, Bowett's Law of International Institutions, Sixth Edition, Sweet \& Maxwell, 2009, pg. 4, footnote 16. Regardless of the existing differences in the exact number of international organizations, there is no doubt that the number of IGOs has increased immensely over the last century.

${ }^{10}$ Inis L. Claude, Jr., The Management of Power in the Changing United Nations, 15 Int'l. Org. 219 (1961), pg. 219.
} 
member would withdraw from it, the international organization would not vanish. ${ }^{11}$ Without their members, they would not exist, and without international organizations membership to such IGO's would not exist. ${ }^{12}$ Member states, after establishing an international organization, strive to maintain control and remain masters of their own creation. ${ }^{13}$ The relationship between international organizations and their members often "takes the form of an inquiry between sovereign equality on the one hand, and membership of an organization on the other". ${ }^{14}$ As stated by Blokker: "international organizations belong to all members and to none". ${ }^{15}$ Therefore it does not come as a surprise that membership policies of international organizations and the principle of equality of states constitute a central part of the law on international organizations. The fact that there are overwhelming differences between states does not make the application of the principle of equality of states in international organizations easy, or at times, viable and realistic. Therefore, the application of the principle of equality of states in international organizations is and will most probably remain a continuous challenge for states and international organizations. As Kooijmans noted, equality is a mathematical notion which when drawn into the legal sphere results in a "doctrine completely at odds with reality, which, of necessity, will involve opposition since reality cannot be forced into a certain conception”. ${ }^{16}$ However, he continues, "it is entirely wrong to pass by and reject a principle so strongly related to legal conviction as is equality because it is said not to conform to reality". 17

\section{RESEARCH QUESTIONS AND METHODOLOGY}

In order to review the application of the principle of equality of states in international organizations, first, a theoretical basis on the evolution and the meaning of the principle of equality of states in international law and in international organizations should be established. Based on this theoretical basis, the application of the principle of equality of states in international organizations will be discussed.

The theoretical basis will discuss the origins and the meaning of the principle of equality of states from its foundations in history until its application in current international organizations. Any discussion on inequality of states in international organiza-

\footnotetext{
${ }^{11}$ Konstantinos D. Magliveras, 'Membership in international organizations’ in Jan Klabbers and Åsa Wallendahl Editors, Research Handbook on the Law of International Organizations, Edward Elgar Publishing Limited, 2011, pg. 84. However, this would mean that even two members out of the three are sufficient for an organization to exist, so it is actually two and not three members, the minimum.

${ }^{12}$ Niels Blokker, International Organizations and Their Members, 1 Int'l. Org. L. Rev. 139 (2004), pg. 161.

${ }^{13}$ Henry G. Schermers \& Niels M. Blokker, International Institutional Law, Fifth Revised Edition, Martinus Nijhoff Publishers, 2011, pg. 23, 1210.

14 Jan Klabbers, Life and Times of the Law of International Organizations, 70 Nordic J. Int'l. L. 287 (2001), pg. 293 and footnote 19.

${ }^{15}$ Niels Blokker, International Organizations and Their Members, 1 Int'l. Org. L. Rev. 139 (2004), subtitle, pg. 139.

${ }^{16}$ Peter H. Kooijmans, The Doctrine of Legal Equality of States: An Inquiry Into the Foundations of International Law, A. W. Sythoff, 1964, pg. 2.

${ }^{17}$ Ibid., pg. 3.
} 
tions should start by analyzing the legal meaning of the notion of equality of states in international organizations. This is so for a simple reason: there is a legal principle of equality which, when is not upheld, determines inequality and not the other way around.

Due to the differences in the meaning and the scope of the principle of equality of states in international law and in international organizations, they will be discussed separately. Moreover, with regard to the principle of equality of states in international organizations, it is important to clarify the scope of review of this principle undertaken in this book. This represents one of the most innovative issues of this book.

In terms of the structure of the theoretical part, the evolution and the meaning of the principle of equality of states from municipal law to international law will be discussed in Chapter $\mathrm{I} ;{ }^{18}$ the evolution and the meaning of the principle of equality of states in international organizations will be discussed in Chapter $\mathrm{II}^{19}{ }^{19}$ and the relevant aspects for review of the principle of equality of states in international organizations are discussed in Chapter $\mathrm{III}^{20}$. This theoretical structure will serve as a basis for the second part of this book dealing with the application of the principle in specific international organizations.

International organizations have similar but not identical institutional frameworks and membership policies due to their empirical evolution. Therefore, the application of the principle of equality of states should be reviewed separately in each and every IGO. This determines the path of inquiry to be not of general theory alone, but also one of a practical review of the application of the principle of equality of states in specific organizations. As such, besides the theoretical bases, by its nature this research is empirical as well. Therefore, the review of the application of the principle of equality of states in international organizations will deal with real, functioning international organizations that decide on the rights and duties of their present but also of their potential members as well. Having in mind that there are hundreds of international organizations with various membership policies, any endeavor of this nature cannot possibly cover all of them. Even if research is limited to the most important international organizations, no scholar can cover on his own the field of law. ${ }^{21}$ In such a variety of hundreds of international organizations, there can always be reasons for including or excluding certain international organizations. The selection criteria of the international organizations discussed in this book are based, first, on the relevance of the international organizations in question, and second, more importantly, whether they represent an important model of the application of the principle of equality of states. Having said this, due to the reasons explained in this section, and throughout this book, the application of the

\footnotetext{
${ }^{18}$ On the evolution and the meaning of the principle of equality of states in international law, see below, Chapter I, pg. 39-58.

${ }^{19}$ On the evolution and the meaning of the principle of equality of states in international organizations, see below, Chapter II, pg. 59-82.

${ }^{20}$ On the review of the principle of equality of states in international organizations, see below, Chapter III, pg. 83-120.

${ }^{21}$ Henry G. Schermers \& Niels M. Blokker, International Institutional Law, Fifth Revised Edition, Martinus Nijhoff Publishers, 2011, pg. 8.
} 
principle of equality of states will be reviewed in the following three international organizations: the United Nations, the World Trade Organization, and the International Monetary Fund. Each of these international organizations is important and relevant and as such represents a principle model of how the principle of equality of states is applied in international organizations.

Briefly, any discussion on international organizations, regardless of the focus, is destined to include the United Nations for at least two reasons. The first reason is that the UN represents arguably the most important international organization of a universal character. $^{22}$ The second reason is that the UN Charter (having the principle of sovereign equality of its members as its first principle) prevails in events of conflict between the obligations of Members with other international agreements placing the UN and its founding treaty in a position of a higher legal norm that prevails in case of collision. ${ }^{23}$ Furthermore, there are views that the UN Charter is not only the Constitution of the UN, but also of the International Community. ${ }^{24}$ As stated by the United Nations Secretary General Dag Hammarskjöld:

"The principles of the Charter are, by far, greater than the organization, in which they are embodied, and the aims which they are to safeguard, are holier than the policies of any single nation or people."25

And finally, the veto powers of the permanent five members of the Security Council are arguably the most cited deviation from the principle of equality of states in international law and international organizations as well. The application of the principle of equality of states in the United Nations is discussed in Chapter IV. ${ }^{26}$

The second organization to be reviewed is the World Trade Organization. The WTO is the most important universal organization dealing with trade. In addition, the WTO is considered to be "the most intricate and profound legal component of international economic law" ${ }^{27}$ The review of the WTO, from the perspective of the principle of equality of states, is important due to its consensual decision-making and the heterogeneous membership including besides states, separate customs territories and an international organization. Consensual decision-making in an organization that has as

\footnotetext{
${ }^{22}$ Note that the term "universal" is criticized by some authors as there is no universal organization that includes all the states of the world. Rather, the terms "universalist” (suggested by Schwarzenberger) or "of potentially universal character” (suggested by Oppenheim) should be used. See C. F. Amerasinghe, Principles of the Institutional Law of International Organizations, Second Edition, Cambridge University Press, 2005, pg. 11.

${ }^{23}$ UN Charter, Article 103, which reads: "In the event of a conflict between the obligations of the Members of the United Nations under the present Charter and their obligations under any other international agreement, their obligations under the present Charter shall prevail.”

${ }^{24}$ Henry G. Schermers \& Niels M. Blokker, International Institutional Law, Fifth Revised Edition, Martinus Nijhoff Publishers, 2011, pg. 11.

${ }^{25}$ Ibid., pg. 1212.

${ }^{26}$ On the application of the principle of equality of states in the United Nations, see below, Chapter IV, pg. 121-186.

27 John H. Jackson, Sovereignty, the WTO and Changing Fundamentals of International Law, Cambridge University Press, 2006, pg. 4.
} 
members other subjects besides states reveals other important ramifications to the application of the principle of equality of states in an international organization. In addition, the WTO is also an interesting organization to review due to the special and differential treatment it provides to its members (states and other) which in reality relates to affirmative action aiming, among other goals, to achieve greater equality among members. The application of the principle of equality of states in the World Trade Organization is discussed in Chapter V. ${ }^{28}$

The third organization to be reviewed is the International Monetary Fund. The IMF is especially interesting for the application of the principle of equality of states as it represents an economic international organization which from its establishment has introduced a decision-making system based on weighted voting primarily dependent on the financial quotas of its Members. Weighted voting is generally considered to represent a deviation from the principle of equality of states. Furthermore, there is an added value in reviewing the IMF, as its model of application of the principle of equality of states in general terms also applies to the World Bank as well. It represents an antithesis of the one-member one-vote rule of the principle of equality of states. The latest reforms of the IMF aiming to improve voice and representation of its members are in line with improving the application of the principle of equality of states and also this represents an additional interest for discussion. The application of the principle of equality of states in the International Monetary Fund is discussed in Chapter VI. ${ }^{29}$

Finally, Chapter VII provides general conclusions on the principle of equality of states in international organizations as well as specific conclusions applicable to the UN, WTO and the IMF. ${ }^{30}$

\section{SOCIETAL AND SCIENTIFIC RELEVANCE}

The application of the principle of equality of states in international organizations has a significant societal and scientific relevance.

With regard to the societal significance, it goes without saying that the societal role and impact of international organizations is of the outmost importance. In today's world, international (IGOs), such as the United Nations (UN), the World Trade Organization (WTO), the International Monetary Fund (IMF), the World Bank (WB) and moreover regional ones such as the Organization for Economic Cooperation and Development (OECD), the African Union (AU), the Association of Southeast Asian Nations (ASEAN), or the Organization of Petroleum Exporting Countries (OPEC) influence the destiny of billions of people. For example, the United Nations strives to maintain

\footnotetext{
${ }^{28}$ On the application of the principle of equality of states in the World Trade Organization, see below, Chapter V, pg. 187-243.

${ }^{29}$ On the application of the principle of equality of states in the International Monetary Fund, see below, Chapter VI, pg. 245-306.

${ }^{30}$ On conclusions for the application of the principle of equality of states in international organizations, see below, Chapter VII, pg. 307-315.
} 
international peace and security, the WTO plays a key role in trade and development, the IMF in monetary cooperation and financial stability and the World Bank in the reduction of poverty. Moreover, regional organizations such as OECD play an important role in promoting policies to improve the economic and social well being of people, the African Union in promoting a peaceful and prosperous Africa, ASEAN in promoting economic, political and security ties among its members, and OPEC influences the price of oil affecting consumers globally. There is no part of the globe or hardly any human activity which is to some extent not governed by an international organization. ${ }^{31}$ Having this in mind, a study of any aspect of international organizations is of great societal relevance. The application of the principle of equality of states is important for existing as well as for future international organizations and their development. Even within existing legal frameworks, international organizations are dynamic and develop their legal and institutional framework among others through the implied powers doctrine, by-laws and practice, and interpretation. Also, at times international organizations do broaden their powers and competencies. In such cases as well, one should have also in mind the principle of equality of states in international organizations.

While there is room for behavioral change within the existing organizations when it comes to the principle of equality of states, there is an undiscovered potential for its application in new, future organizations to be established. The number of states and the number of international organizations has continuously and systematically increased over time. States are finding international organizations to be a more efficient way to solve the problems of the modern world which no state alone, no matter how powerful, can. The question of whether or not there is application of the principle of equality of states in international organizations and whether deviations from the principle of equality of states create situations of inequality is at the heart of state behavior and the will to fully participate in the efficient functioning of any international organization.

With regard to the scientific relevance, it is important to note that the principle of equality of states in international law and in international organizations has not been reviewed sufficiently. ${ }^{32}$ It should be noted, however, that the principle of equality of states in international law has received more attention by scholars compared to the principle of equality of states in the law of international organizations. ${ }^{33}$

\footnotetext{
31 Jan Klabbers, An Introduction to International Institutional Law, Second Edition, Cambridge University Press, 2009, pg. 21.

${ }^{32}$ As stated by Efraim: "there are but a handful of publications dedicated to the study of Sovereign Equality and fewer still examine seriously the observance of breach of this principle, while standard manuals of international law and international organizations usually mention the matter only briefly and often superficially.” See Athena Debbie Efraim, Sovereign (In)equality in International Organizations, Martinus Nijhoff, 2000, pg. 19. Also others give similar references: "Quite surprisingly, the role of power inequality in the international legal system has rarely been studied systematically”. See Nico Krisch, International Law in Times of Hegemony: Unequal Powers and the Shaping of the International Legal Order, 16 Eur. J. Int'l. L. 369 (2005) pg. 372.

${ }_{33}$ Perhaps the difference may be justified and reasonable having in mind the time difference of around 300 years between the establishment of international law and the law of international organizations. While the
} 
In international law, the principle of equality of states during the first half of the XX century was primarily addressed in books by Dickinson ${ }^{34}$ and Goebel ${ }^{35}$ and in the second half of the XX century by Kooijmans ${ }^{36}$, Klein ${ }^{37}$, Anand ${ }^{38}$, and more recently by Roth $^{39}$. In addition there were several book chapters ${ }^{40}$ and articles ${ }^{41}$ dealing with the issue as well.

On the other hand, the application of the principle of equality of states in international organizations was the focus of only a few major scholarly publications. ${ }^{42}$ Chrono-

foundations of the current international legal system were established with the Peace of Westphalia in the XVII century, one can only speak of the development of the first political international organizations in the XX century with the establishment of the League of Nations and the International Labor Organization.

${ }^{34}$ See Edwin DeWitt Dickinson, The Equality of States in International Law, Harvard University Press, 1920.

35 Julius Goebel, Jr. The Equality of States: A Study in the History of Law. Columbia University Press, New York, 1923 based on the following three journal articles: Julius Goebel, Jr., The Equality of States, 23 Colum. L. Rev. 1 (1923); Julius Goebel, Jr., The Equality of States II, 23 Colum. L. Rev. 113 (1923); Julius Goebel, Jr., The Equality of States, 23 Colum. L. Rev. 247 (1923).

${ }^{36}$ Peter H. Kooijmans, The Doctrine of Legal Equality of States: An Inquiry Into the Foundations of International Law, A. W. Sythoff, 1964.

${ }^{37}$ Robert A. Klein, Sovereign Equality Among States: The History of an Idea, University of Toronto Press, 1974.

${ }^{38}$ R. P. Anand, Sovereign Equality of States and International Law, Hope India Publications, 2008. Though this book has been recently published, in fact it contains the lectures delivered by the author at the Hague Academy of International Law in 1986.

${ }^{39}$ Brad R. Roth, Sovereign Equality and Moral Disagreement: Premises of a Pluralist International Legal Order, Oxford University Press, 2011.

${ }^{40}$ See Colin Warbrick, 'The principle of sovereign equality' in Colin Warbrick and Vaughan Lowe, Editors, The United Nations and the Principles of International Law, Essays in Memory of Michael Akehurst, Routledge, 1994; Benedict Kingsbury, 'Sovereignty and Inequality' in Andrew Hurrell and Ngaire Woods, Editors, Inequality, Globalization, and World Politics, Oxford University Press, 1999.

${ }^{41}$ See for example (in chronological order): Philip Marshall Brown, The Theory of the Independence and Equality of States, 9 Amer. J. Int'l. L. 305 (1915); S. W. Armstrong, The Doctrine of the Equality of Nations in International Law and the Relation of the Doctrine to the Treaty of Versailles, 14 Am. J. Int'l. L. 540 (1920); Talcott Williams, The Misleading Myth of the Equality of Nations, 96 Annals of the American Academy of Political and Social Science, The Place of the United States in a World Organization for Maintenance of Peace, 124 (1921); Arnold D. McNair, Equality in International Law, 26 Mich. L. Rev. 131 (19271928); P. J. Baker, The Doctrine of Legal Equality of States, 4 Brit. Y. B. Int'l. L. 1 (1923-1924); William Timothy Kao, The Equality of States, 3 China L. Rev. 112 (1926-1929); Herbert Weinsohel, The Doctrine of the Equality of States and its Recent Modifications, 45 Am. J. Int'l. L. 417 (1951); Quincy Wright, Equality of States, 3 Cornell Int'l. L. J. 1 (1970); Alan James, The Equality of States: Contemporary Manifestations of an Ancient Doctrine, 18 Rev. Int'l. Stud. 377 (1992); Ulrich K. Preuß, Equality of States-Its Meaning in a Constitutionalized Global Order, 9 Chi. J. Int'l. L. 17 (2008-2009); Juliane Kokott, States, Sovereign Equality, Max Planck Encyclopedia of Public International Law, para. 57-58; Janne E. Nijman and Wouter G. Werner, Legal Equality and the International Rule of Law, 43 Neth. YBIL 3 (2013); Brad R. Roth, Sovereign Equality and Non-Liberal Regimes, 43 Neth. YBIL 25 (2013).

${ }^{42}$ According to Klabbers, the question of sovereign equality and membership in international organizations has been reviewed by Dickinson in the 1920s, by Broms in the 1950s and "re-discovered in all its confusing aspects" by Martinez and Efraim in 1996 and 2000. See Jan Klabbers, Life and Times of the Law of International Organizations, 70 Nordic J. Int'l. L. 287 (2001), pg. 293. Here, it should be noted that the book of Edwin DeWitt Dickinson, The Equality of States in International Law, Harvard University Press, 1920, primarily deals with the principle of equality of states in international law and not international organizations, while the book of Bengt Broms, The Doctrine of Equality of States as Applied in International Organizations, Vammala Kirjapaino, 1959, specifically deals with the principle of equality of states and its application in a number of organizations. The book of Magdalena M. Martin Martinez, National Sovereignty and International Organizations, Kluwer Law International, 1996, is focusing on the transfer of sovereignty from states to international organizations and not on the principle of equality of states in international organizations. The book of Athena Debbie Efraim, Sovereign (In)equality in International Organizations, Martinus Nijhoff, 2000, 
logically, around seven decades ago, Kelsen ${ }^{43}$ in a journal article discussed the application of the principle of equality of states in the United Nations while Simpson ${ }^{44}$ reviewed the application of the principle of equality in the making of the UN Charter. More recently, Dunoff discussed the principle of sovereign equality in international organizations. ${ }^{45}$

Seemingly the most detailed account so far on the application of the principle of equality of states in international organizations is offered by the $\mathrm{PhD}$ thesis written by Bengt Broms more than five decades ago. ${ }^{46}$ Broms reviews the principle of equality of states and its application in a number of organizations such as the League of Nations, the United Nations, international administrative organizations, Inter-American international organizations, the League of Arab States, the Council of Europe, the Northern Council and international judicial organizations.

The most recent publication on the application of the principle of equality of states in international organizations is the 2000 book by Athena Debbie Efraim on "Sovereign (In) equality in International Organizations". This book reviews the application of the principle of equality of states from the perspective of decision-making processes in the following six international organizations: the UN, the International Labor Organization (ILO), the IMF, the Multilateral Investment Guarantee Agency (MIGA), the European Union (EU), and the OECD. The main proposition of the book is in favor of the preservation of the principle of equality of states in international law and its abolition in the law of international organizations.

\section{SCOPE OF RESEARCH}

The area of law to be covered by this book is obviously vast, making this research very ambitious indeed. In order to achieve its goal, it will focus only on issues of immediate relevance of the core research question.

First, concerning the theoretical part, the principle of equality of states will encompass the review of the legal principle in municipal law, international law and in international organizations law by focusing on the most important sources of law and the opinions of well-known scholars. It will not include the revision of the principle of equality of states to other aspects of international law and international organizations such as, for example, equality and immunity from jurisdiction or diplomatic protection.

argues against the application of the principle of equality of states in international organizations and at the same time reviews its application in a number of international organizations limiting its focus primarily to decision-making processes.

${ }^{43}$ Hans Kelsen, The Principle of Sovereign Equality of States as a Basis for International Organization, 53 Yale L. J. 207 (1943-1944).

${ }^{44}$ See Gerry Simpson, The Great Powers, Sovereign Equality and the Making of the United Nations Charter, 21 Aust. YBIL 133 (2000).

45 Jeffrey L. Dunoff, Is Sovereign Equality Obsolete? Understanding Twenty-First Century International Organizations, 43 Neth. YBIL 99 (2013).

${ }^{46}$ Bengt Broms, The Doctrine of Equality of States as Applied in International Organizations, Vammala Kirjapaino, 1959. 
Second, under the heading "international organizations" it is understood only governmental international organizations and, therefore, nongovernmental ones will be excluded. Moreover, the review will not cover all governmental international organizations but will limit itself to the UN, the WTO, and the IMF.

Third, the application of the principle of equality of states in international organizations will cover only full members of organizations thus excluding other forms of membership (such as associate members or observers).

Fourth, it is needless to say that it is not possible to review all and every possible situation of the application of the principle of equality in membership in international organizations. This is not possible, and neither is it possible in municipal law in regard to the application of the principle of equality of natural persons. The goal is to review the application of the principle through the basic legal sources of international organizations as well as through relevant case studies.

Fifth, the review of the principle of equality of states will focus only on the institutional aspects of international organizations and not on their substantive law. However, it should be noted that it is not possible to rule out completely substantive law references as they are at times fundamentally linked to the institutional law of international organizations. Therefore, some relevant references to substantive law may be provided as well.

Sixth, the review of the principle of equality of states in IGOs will focus only in the formal equality of states and not on the substantive (in) equality of states. For example, in the decision-making processes the focus will be to review whether the principle of equality of states is applied in the formal decision-making processes envisaged by the law applicable in a particular IGO and not on the various informal decisionmaking practices. However, at times there may be references to substantive inequality of states or informal decision-making processes to illustrate the difficulties that exist in the application of the principle of equality of states in IGOs. 


\section{CHAPTER I \\ THE EVOLUTION OF THE PRINCIPLE OF EQUALI- TY OF STATES IN INTERNATIONAL LAW}

\section{INTRODUCTION}

The principle of equality of states as a principle of international law is the cornerstone of the application of the principle of equality of states in international organizations. Therefore, before reviewing the principle of equality of states in international organizations, the principle of equality of states in international law will be discussed.

As is usually the case with the development of legal principles of international law, there is a pattern and a specific chronological order of development. The principle of equality of states is not an exception in this regard. Historically, it evolved through the writings of various publicists on the ideal of equality of men. The ideal of equality of men further developed into a legal principle of equality of men in municipal law. From the principle of equality of men in municipal law, by analogy, the principle of equality of states developed in international law. In simple terms, if men by law are equal, states should also by law be equal. Therefore, if there is equality between men in municipal law, there should also be equality between states in international law. This is how the principle of equality of states became a principle of international law.

However, this development was far from simple and short in history. Having this in mind, this chapter will start by discussing the principle of equality of men from its origin in municipal law up to the consequent development of the principle of equality of states in international law. The application and the meaning of the principle of equality of states in international organizations will be reviewed separately in the next chapter and will not be introduced here.

\section{THE MUNICIPAL LAW ORIGINS OF THE PRINCIPLE OF EQUALITY OF STATES}

As is the case with most legal principles of international law, the origins of the principle of equality of states can be traced to municipal law. The evolution of legal principles from municipal to international law is not unusual. In this regard, it is important to have in mind the general principles of law recognized by civilized nations according to the Statute of the International Court of Justice as one of the main sources of international 
law. ${ }^{47}$ For example, international tribunals as well as legal scholars have often looked into the possibility of reviewing the basic principles of international law from municipal law as was the case with principles such as pacta sund servanda or the principle of good faith. This seems to have been the case also with the principle of equality of men in municipal law and its transformation to the principle of equality of states in international law.

Municipal law references to equality primarily focused on the ideal of equality of men. Inequality between men existed in human society and it was not easy to move beyond the ideal of equality of men and establish the legal principle of equality of men. ${ }^{48}$ According to Rousseau the origins of inequality between men lie in the origins of private property. In his work: "A Discourse Upon the Origin and the Foundation of the Inequality Among Mankind” he states:

"the first man, who, after enclosing a piece of ground, took it into his head to say: 'this is mine,' and found people simple enough to believe him, was the true founder of civil society... Be sure not to listen to this imposter; you are lost, if you forget that the fruits of the earth belong equally to us all, and the earth itself to nobody!" ${ }^{49}$

There are two types of inequality among men: first are natural, second are moral or political inequalities. ${ }^{50}$ The natural or physical inequality relates to differences of age, health, bodily strength, qualities of the mind, or of the soul. On the other hand, the moral or political inequality consists in the privileges, which some enjoy to the prejudice of others of being richer, more honored, more powerful.

Regardless of the origins of inequality, severe forms of inequality between men such as slavery and other forms of discrimination (racial, ethnic, gender) were quite common and at times not even sanctioned by law. The ideal of equality of men existed, but without being legally sanctioned it was not enforceable. Therefore, it was a necessity to establish the principle of equality of men which would be sanctioned by municipal law. This process of development of the ideal and legal principle of equality of men is considered to have lasted for a relatively long time in human history. Dickinson attributes the birth of the rudimentary forms of the origins of the principle of equality of men to the philosophy of ancient Greece, with philosophers whose ideas were further carried by Roman lawyers and medieval thinking to be received by classical publicists. Other authors give more merit to religion as a basis for the development of the principle of

${ }^{47}$ See the Statute of the International Court of Justice, Article 38 (1) (c).

${ }^{48}$ According to Kooijmans, equality as a notion finds its origins in mathematics, as only in mathematics (as an abstract science) it can be stated that two units are equal, see Peter H. Kooijmans, The Doctrine of Legal Equality of States: An Inquiry Into the Foundations of International Law, A. W. Sythoff, 1964, pg. 7.

${ }_{49}$ See Jean-Jacques Rousseau, A Discourse Upon the Origin and the Foundation of the Inequality Among Mankind, 1755, published by Echo Library, 2007, pg. 38.

${ }^{50}$ Ibid., pg. 5. 
equality based on religious sources and tradition. ${ }^{51}$ An important shift in the promotion of equality of men and perhaps a cornerstone in its development, was made in the XVIII century with two important historical developments in the US and France. They provided for an important momentum to the development of the principle of equality of men in municipal law and subsequently, by analogy, to the development of the principle of equality of states in international law. In a relatively short period of time, on two continents, North America and Europe, the US declared independence and France had a revolution. Both events had a remarkable influence on human history. The first, in 1776, gave birth to the greatest power of today, and the second, in 1789 started a revolution that had an immense influence in Europe and beyond. And in both of these events the ideal of equality of men and the principle of equality had a significant role to play.

In the United States, the US Declaration of Independence states that:

"We hold these truths to be self-evident, that all men are created equal, that they are endowed by their Creator with certain unalienable rights that among these are Life, Liberty and the pursuit of Happiness. "\$2

Similarly, in France the revolution of 1789 had the idea of equality besides the ones of liberty and fraternity as its main basis. ${ }^{53}$ On these lines the French Declaration of the Rights of Man and of the Citizen was drafted. Article 1 of the Declaration stated that "men are born and remain free and equal in rights". Article 6 stated that:

"all citizens, being equal in the eyes of the law, are equally eligible to all dignities and to all public positions and occupations, according to their abilities, and without distinction except that of their virtues and talents. ${ }^{\text {}} 54$

These events had an enormous impact on human history influencing among others the promotion and establishment of the ideal and legal principle of equality of men. Gaining support in different parts of the world the ideal of equality of men was transformed into a principle of law which served as a legal basis as well as an inspiration. ${ }^{55}$ Today, it

\footnotetext{
${ }^{51}$ For further reference see George P. Fletcher, In God's Image: The Religious Imperative of Equality under Law, 99 Colum. L. Rev. 1608 (1999), pg. 1608-1629. The assertion is that western thought was influenced by religion and this is overlooked according to the author. Also Dickinson considers the law of nature as a body of principles "grounded in the being of God, ascertained by reason and distinct from the jus gentium and all positive law”, see Edwin DeWitt Dickinson, The Equality of States in International Law, Harvard University Press, 1920, pg. 31.

52 The Declaration of Independence, by Thomas Jefferson, US Congress, July 4, 1776.

${ }^{53}$ Liberty, Equality, Fraternity, is the maxim of the French Republic today as well, see Article 2 of the Constitution of France.

${ }^{54}$ The Declaration of the Rights of Man and of the Citizen, Approved by the National Assembly of France, August 26, 1789.

${ }^{55}$ See for example C. Wilfred Jenks, The Equality of Man in International Law, 13 Howard L. J. 321 (1967); Martha Albertson Fineman, Equality Across Legal Cultures: The Role for International Human Rights, 27 T. Jefferson L. Rev. 1 (2004-2005); Anja Seibert-Fohr, The Rise of Equality in International Law and its Pitfalls: Learning from Comparative Constitutional Law, 35 Brook. J. Int’l. L. 1 (2010).
} 
would be extremely hard to find any national legislation that at least formally does not provide for the equality of natural persons.

\section{THE TRANSFORMATION OF THE PRINCIPLE OF EQUALITY OF MEN INTO THE PRINCIPLE OF EQUALITY OF STATES}

The principle of equality of men, transformed to the principle of equality of states in international law. The transformation from municipal law to international law was made through the analogy between men or natural persons as primary subjects of municipal law, to states as primary subjects of international law. ${ }^{56}$ This is quite natural as the primary subjects of municipal law were natural persons and not states. In fact, even without the analogy between man and state, the result would have been the same because states as entities that do not recognize any superior authority can only be considered to have equal voices in all legal matters. ${ }^{57}$

The main proposition is that the transformation from municipal law was primarily influenced by the writings of various publicists. While there seem to exist some consensus on this fact in legal doctrine, there is no consensus between scholars about the author who was first to introduce the principle of equality of states. There is a debate about whether it was Hobbes, Puffendorf, Leibniz, Vattel or that in fact it was Grotius.

According to Dickinson and Baker, it was Puffendorf who inspired by Hobbes first introduced the principle of equality of states. Puffendorf stated:

"all persons in a state of nature are equal; the persons of international law are in a state of nature; therefore they are equal."

According to others, the principle of equality of states evolved through the influence of the writings not only of Thomas Hobbes but also Leibnitz in the XVII century ${ }^{59}$ According to Goebel, Dickinson was not correct in attributing to Puffendorf the creation of the principle of equality of states because it was Leibniz who was the first to draw the

\footnotetext{
${ }^{56}$ The analogy from equality of men to the equality of states was not a surprise because this tradition has found application in international law for quite some time. There has been a long history in making an analogy to compare every human organization to natural body. The example given by John of Salisbury is quite interesting as he described the "servants of religion as the soul of the state, the prince as the head, the senate as the heart, officers and judges as the eyes, ears and tongue, the executive as the unarmed and the army as the armed hand, the financial department as the belly and intestines, and land folk, handicraftsmen, and the like as the feet...”. See Edwin DeWitt Dickinson, The Equality of States in International Law, Harvard University Press, 1920, pg. 29-31.

${ }^{57}$ Herbert Weinsohel, The Doctrine of the Equality of States and its Recent Modifications, 45 Am. J. Int'l. L. 417 (1951), pg. 418.

${ }^{58}$ P. J. Baker, The Doctrine of Legal Equality of States, 4 Brit. Y. B. Int'l. L. 1 (1923-1924), pg. 6. Also see: Edwin DeWitt Dickinson, The Equality of States in International Law, Harvard University Press, 1920, pg. 334.

${ }^{59}$ Ann Van Wynen Thomas and A. J. Thomas, Jr., Equality of States in International Law, Fact or Fiction, 37 Va. L. Rev. 791 (1951), pg. 792.
} 
principle of equality of states. ${ }^{60}$ Shaw on the other hand is of the opinion that Vattel introduced the doctrine of equality of states into international law. ${ }^{61}$ In similar lines, according to Westlake, the doctrine of equality of states developed by Vattel was inspired by writings of Wolff in the "Jus Gentium". ${ }^{62}$ Vattel actually gave a clearer statement on equality than Puffendorf. Based on the premise that men are equal, Emer de Vattel considered states to be equal by nature as they are composed by men who were equal by nature. He stated:

"Since men are by nature equal, and their individual rights and obligations the same, as coming equally from nature, Nations, which are composed of men and may be regarded as so many free persons living together in a state of nature, are by nature equal and hold from nature the same obligation and the same rights. Strength or weakness, in this case, counts for nothing. A dwarf is as much a man as a giant is; a small Republic is no less a sovereign State than the most powerful Kingdom." ${ }^{63}$

This phrase that the "dwarf is as much a man as a giant is" has been repeated throughout the landscape of literature on equality of states without which the issue cannot be easily described.

As is usually the case with regard to the origins of international law, without a doubt not much can escape the shadow of Grotius. There is a debate among scholars about whether or not Grotius was also responsible for introducing the principle of equality of states in international law. According to Dickinson, Grotius did not develop the principle of equality of states as there is no proof of this in his work. He stated that an idea of a general principle of equality was "never developed by him (Grotius), either expressly, or by necessary implication" and that he "neither formulated a statement of the principle of state equality nor made it an essential element of his system" ${ }^{64}$ However in elaborating his position, Dickinson observed that in his work Grotius had the principle of equality of states as a fundamental principle, however equal capacity for rights as a meaning of the principle was never part of the Grotian system. ${ }^{65}$ This opinion is shared by other authors as well. ${ }^{66}$ Many scholars interpret the principle of equality of states as "equal capacity for rights" and this was not part of the writings by Grotius. ${ }^{67}$

${ }^{60}$ Goebel, Julius Jr., The Equality of States, 23 Colum. L. Rev. 247 (1923), pg. 276.

${ }^{61}$ Malcolm N, Shaw, International Law, Sixth Edition, Cambridge University Press, 2008, pg. 26.

${ }^{62}$ See John Westlake, Chapters on the Principles of International Law, Cambridge University Press, 1894, pg. 86-89.

${ }^{63}$ Ulrich K. Preuß, Equality of States-Its Meaning in a Constitutionalized Global Order, 9 Chi. J. Int'l. L. 17 (2008-2009), pg. 18-19.

${ }^{64}$ Edwin DeWitt Dickinson, The Equality of States in International Law, Harvard University Press, 1920, pg. 34, 40.

${ }^{65}$ Ibid., pg. 34-67.

${ }^{66}$ See Hidemi Suganami, 'Grotius and International Equality’ in Hedley Bull, Benedict Kingsbury, Adam Roberts, Editors, Hugo Grotius and International Relations, Oxford University Press, 1990, pg. 229-230.

${ }^{67}$ Baker and Dickinson have both come to this conclusion, see: Edwin DeWitt Dickinson, The Equality of States in International Law, Harvard University Press, 1920, pg. 34-67 and P. J. Baker, The Doctrine of Legal 
On the other hand, there are scholars who attribute the principle of equality of states to Grotius. $^{68}$ This is true in regard to the opinion that from Grotius one can easily draw the conclusion that states are equal before the law.

While the debate over who introduced the principle of equality in international law may continue, one thing is certain, it was introduced by naturalists who believed that if men were equal also states are equal.

\section{THE PRINCIPLE OF EQUALITY OF STATES IN INTERNATIONAL LAW}

Throughout history, the international community of states has made efforts to base its relations on a number of governing principles that over time evolved into the body of rules constituting what is known today as international law. Among these basic principles, the principle of equality of states is one of the main principles of international law. As early as 1825, Chief Justice Marshall in the Antelope case stated that:

"No principle of general law is more universally acknowledged than the perfect equality of nations. Russia and Geneva have equal rights. ${ }^{\prime 69}$

In similar terms, according to Brown in 1915, the right of a state to exist, independence, and equality are considered "the fundamental postulates of international law". ${ }^{70}$ Oppenheim in 1921 stated that equality of states is the "indispensable foundation of international society" ${ }^{71}$ A number of leading scholars of present international law such as Brownlie consider the principle of equality of states a general principle of international law. ${ }^{72}$ According to Brownlie, the sovereignty and equality of states:

"represent the basic constitutional doctrine of the law of nations, which governs a community consisting primarily of states having a uniform personality."73

\footnotetext{
Equality of States, 4 Brit. Y. B. Int'l. L. 1 (1923-1924), pg. 6. Also research on Grotius and his impact on international relations introduce a similar conclusion, see: Hidemi Suganami, 'Grotius and International Equality’ in Hedley Bull, Benedict Kingsbury, Adam Roberts, Editors, Hugo Grotius and International Relations, Oxford University Press, 1990, pg. 229-230.

${ }^{68}$ Talcott Williams, The Misleading Myth of the Equality of Nations, 96 Annals of the American Academy of Political and Social Science, The Place of the United States in a World Organization for Maintenance of Peace, 124 (1921), pg. 125.

69 The Antelope, 23 U.S. 66 (1825); Philip Marshall Brown, The Theory of the Independence and Equality of States, 9 Amer. J. Int'l. L. 305 (1915), pg. 327.

${ }^{70}$ See Philip Marshall Brown, The Theory of the Independence and Equality of States, 9 Amer. J. Int'l. L. 305 (1915), pg. 305-306, 321. According to the author these postulates of international law are also considered: "fundamental," "primordial," "inherent," or "absolute rights" of states.

${ }^{71}$ L. Oppenheim, The Future of International Law, Carnegie Endowment for International Peace, Pamphlet No. 39, 1921, pg. 20.

72 Ian Brownlie, Principles of Public International Law, Sixth Edition, Oxford University Press, 2003, pg. 18.

${ }^{73}$ Ian Brownlie, Principles of International Law, Oxford University Press, Fourth Edition, 1990, pg. 287,

reference by Colin Warbrick, 'The principle of sovereign equality' in Colin Warbrick and Vaughan Lowe,
} 
According to Cassese, in the founding stages of the present international community, one of the main postulates of states in their international affairs is the principle of equality (the other postulates being the principle of freedom and the principle of effectiveness). ${ }^{74}$ He continues:

"it is safe to conclude that sovereign equality constitutes the linchpin of the whole body of international legal standards, the fundamental premise on which all international relations rest." 75

Similarly, Shaw considers the principle of equality of states a crucial principle which entails equality of rights and duties irrespective of power and that the doctrine of the legal equality of states:

"Is an umbrella category for it includes within its scope the recognized rights and obligations which fall upon all states." 76

Shaw and Cassese consider the principle of equality of states as an umbrella type of a principle.

Beyond legal doctrine, the principle of equality found its way in a number of international conventions, resolutions and declarations. We refer to some of them in a chronological order. Article 4 of the Montevideo Convention on Rights and Duties of States reads the following:

"States are juridically equal, enjoy the same rights, and have equal capacity in their exercise. The rights of each one do not depend upon the power which it possesses to assure its exercise, but upon the simple fact of its existence as a person under international law. The fundamental rights of States are not susceptible of being affected in any manner.",77

The Montevideo Convention on Rights and Duties of States seems to draw in its wording both meanings of the principle of equality of states: the one of equality before the law and the one of equal capacity for rights and duties. ${ }^{78}$ The first sentence of Article 4 refers to equality before the law (though not directly in absolute terms) when stating that "states are juridically equal" and refers to equal capacity for rights when stating that states "have equal capacity in the exercise".

Editors, The United Nations and the Principles of International Law, Essays in Memory of Michael Akehurst, Routledge, 1994, pg. 205.

${ }^{74}$ Antonio Cassese, International Law, Second Edition, Oxford University Press, 2005, pg. 46.

${ }^{75}$ Ibid., pg. 47.

${ }^{76}$ Malcolm N. Shaw, International Law, Sixth Edition, Cambridge University Press, 2008, pg. 214.

${ }^{77}$ The Montevideo Convention on Rights and Duties of States, 1933, Article 4.

${ }^{78}$ For a discussion on the meaning of the principle of equality of states in international law, see Chapter I below, pg. 55-57. 
The principle of equality of states was also upheld by the Declaration on Principles of International Law concerning Friendly Relations and Co-operation among States in accordance with the Charter of the United Nations which states:

"All States enjoy sovereign equality. They have equal rights and duties and are equal members of the international community, notwithstanding difference of an economic, social, political or other nature. In particular, sovereign equality includes the following elements: $a$. States are juridically equal; $b$. Each State enjoys the rights inherent in full sovereignty; $c$. Each State has the duty to respect the personality of other States; $d$. The territorial integrity and political independence of the State are inviolable; e. Each State has the right freely to choose and develop its political, social, economic and cultural systems; f. Each State has the duty to comply fully and in good faith with its international obligations and to live in peace with other States."

This Declaration is quite important and deserves further analysis. According to Cassese the principles of the Declaration are "universal and fundamental" with the mere fact that they apply to all states in contrast to those of the UN Charter that applied only to UN Member States. ${ }^{80}$

The preparatory work on this Declaration also included the establishment of a special U.N. Committee on the Principles of International Law Concerning Friendly Relations and Co-operation among States which was able to reach a consensus on a number of points with regard to the principle of equality of states. ${ }^{81}$ In total four written proposals were submitted by Czechoslovakia, Yugoslavia, the United Kingdom of Great Britain and Northern Ireland, and jointly by Ghana, India, Mexico and Yugoslavia. Czechoslovakia among others stated that: states are equal among themselves, have equal rights and duties, and have the right to join international organizations and that no reason can restrict the capacity to act or assume obligations as equal members. Yugoslavia among others submitted that under the principle of sovereign equality, states have the right to:

"legal equality and to full and equal participation in the life of the community of nations and in the creation and modification of rules of international law." ${ }^{, 2}$

The United Kingdom among others took the position that states are juridically equal, which was explained in the commentary as being equal before the law. The joint proposal by Ghana, India, Mexico and Yugoslavia stated that every state enjoys rights

\footnotetext{
${ }^{79}$ GA Res 2625 (XXV) (1970). Declaration on Principles of International Law concerning Friendly Relations and Co-operation among States in accordance with the Charter of the United Nations.

${ }^{80}$ Antonio Cassese, International Law, Second Edition, Oxford University Press, 2005, pg. $46-47$.

${ }^{81}$ See Report of the Special Committee on Principles of International Law Concerning Friendly Relations and Co-operation among States, United Nations Document A/5746 (November 16, 1964), pg. 148-170.

${ }^{82}$ Ibid., pg. 148-149,
} 
inherent in sovereignty. The result of the submissions was that a consensus was reached on a number of points out of which the most important is that sovereign equality includes the following elements: states are juridically equal, enjoy rights inherent in full sovereignty, have a duty to respect the personality of other states, respect for the inviolability of their territorial integrity and independence, freedom to choose their system (political, social, economic and cultural), and to fully comply in good faith with international obligations and peace with other states. ${ }^{83}$

Whether states have a right to participate in the solution of issues, including the right to join international organizations and become party to multilateral treaties, according to the Committee, was an item on which there is no consensus but for which there is support. ${ }^{84}$

Beyond the Declaration on Friendly Relations among Nations, the Charter of Economic Rights and Duties of States also reaffirmed the principle of equality of states. ${ }^{85}$ In Chapter I, dealing with the fundamentals of international economic relations, the Charter gives a number of basic principles among which some make direct and others indirect references to the principle of equality of states. According to the Charter, the economic, political and other relations between states among others shall be governed by: sovereign equality of all states, mutual and equitable benefit, equal rights and selfdetermination of peoples, remedying injustices brought by force and which deprive nations of natural means necessary for normal development, no attempt to seek hegemony and spheres of influence, promotion of international social justice. ${ }^{86}$

The most representative statement concerning the principle of equality of states can be found in Article 10 which states that:

"All states are juridically equal and, as equal members of the international community, have the right to participate fully and effectively in the international decision-making process in the solution of world, economic, financial and monetary problems, inter alia, through the appropriate international organizations in accordance with their existing and evolving rules, and to share in the benefits resulting thereform." 87

\footnotetext{
${ }^{83}$ Ibid., pg. 163.

${ }^{84}$ On this, according to Annex B, paragraph 2 of the Report of the Special Committee, Czechoslovakia, Romania, Poland, USSR, and Ghana were in favor of such a right, while Mexico was of the opinion that it is difficult to speak of such a right and France that the Committee should not deal with the issue. The UK and Australia were of the opinion that there are difficulties in view of Article 4 of the Charter dealing with admission of members and its practice. See Report of the Special Committee on Principles of International Law Concerning Friendly Relations and Co-operation among States, United Nations Document A/5746 (November 16, 1964), pg. 167.

${ }^{85}$ GA Res 3281 (XXIX), (1974) Charter of Economic Rights and Duties of States.

${ }^{86}$ GA Res 3281 (XXIX), (1974) Charter of Economic Rights and Duties of States, Chapter I, principles.

${ }^{87}$ GA Res 3281 (XXIX), (1974) Charter of Economic Rights and Duties of States, Article 10.
} 
Also the Vienna Convention on the Representation of States in their Relations with International Organizations of a Universal Character refers to the principles of sovereign equality of states as a basic principle on which the convention was drafted. ${ }^{88}$

Finally, there are authors such as Efraim and Franck that consider the principle of equality of states to be a jus cogens norm of international law. ${ }^{89}$ This, in simple terms, means that the principle of equality of states belongs to the category of highest possible norms of international law. Therefore, the issue deserves some further attention.

\section{THE PRINCIPLE OF EQUALITY OF STATES, A JUS COGENS NORM OF INTERNATIONAL LAW?}

What are jus cogens norms, how are they established and what is their importance for the principle of equality of states? The widest accepted definition of peremptory norms is the one given by Article 53 of the Vienna Convention on the Law of Treaties (VCLT) ${ }^{90}$ It reads:

"A treaty is void if, at the time of its conclusion, it conflicts with a peremptory norm of general international law. For the purposes of the present Convention a peremptory norm of general international law is a norm accepted and recognized by the international community of States as a whole as a norm from which no derogation is permitted and which can be modified only by a subsequent norm of general international law having the same character." $" 1$

It is also important to note the fact that according to Article 64 of the VCLT, regardless of when a treaty was signed, if it conflicts with a peremptory norm (which either existed at the time or developed after the treaty), it will be void. This is an exception to the general legal rule that laws cannot have retroactive effect. This obviously is not applicable to jus cogens norms.

The VCLT was the outcome of the work of the International Law Commission (ILC) and two sessions of the United Nations Conference on the Law of Treaties held in 1968 and 1969. The ILC in the VCLT established a high requirement for any norm to be considered as peremptory with three tests which would establish in a concrete instance whether or not a rule is peremptory. Namely the peremptory norm must be: 1 . accepted

\footnotetext{
${ }^{88}$ Vienna Convention on the Representation of States in their Relations with International Organization of a Universal Character, 1975, Preamble, $2^{\text {nd }}$ paragraph.

${ }^{89}$ See Athena Debbie Efraim, Sovereign (In)equality in International Organizations, Martinus Nijhoff, 2000, pg. 84-90. In fact, Efraim considers sovereign equality to be “widely recognized as jus cogens”, see pg. 88. Efraim argues that the principle of equality of states is a peremptory norm of international law (or a jus cogens). However, the author is of the opinion that the principle of equality of states should preserve its position of a jus cogens norm in international law and that should be abolished from international organizations law. Also see Thomas M. Franck, Legitimacy in the International System, 82 Am. J. Int'l. L. 705 (1988), pg. 757-758, reference from Athena Debbie Efraim, Sovereign (In)equality in International Organizations, Martinus Nijhoff, 2000, pg. 88, footnote 352.

${ }^{90}$ Ian Brownlie, Principles of Public International Law, Sixth Edition, Oxford University Press, 2003, pg. 489.

${ }^{91}$ The Vienna Convention on the Law of Treaties of 1969, Article 53.
} 
and recognized by the international community as a whole; 2. a norm from which no derogation is permitted, and 3. a norm which can be modified only by a subsequent norm of general international law having the same character. ${ }^{92}$

The wording of the first test, namely the "acceptance and recognition by the international community as a whole" as stated by Yaseen (the Chairman of the Drafting Committee at the Vienna Conference) provided for full accordance with the wording of Article 38, 1, of the Statute of the ICJ using the terms "recognition" (for international conventions and general principles of law) and "acceptance" (for international custom).$^{93}$ Furthermore, the text contains the expression "international community as a whole". During the work of codification of the Convention, it was explained that the words "as a whole" were added in order not to allow "one state in isolation", or "a very small number of states" to preclude the acceptance and recognition of a norm as jus cogens.

The second test relates to the wording that "no derogation is permitted". This implies that derogations are not permitted either by unilateral means of individual state nor by bilateral, plurilateral or multilateral treaties.

The third test regarding the wording "modified only by a subsequent norm of general international law having the same character" means that a modification of an existing jus cogens norm can occur only when a norm is replaced by another norm which regulates the same subject in a different way.

The preferred solution by the International Law Commission when discussing the Vienna Convention on the Law of Treaties was not to enumerate any examples in the text of the VCLT. Therefore, in the Draft Articles on the Law of Treaties the Commission refrained from giving any examples of jus cogens norms. However, some examples were given in the commentaries of the Draft Articles on the Law of Treaties. The ILC made reference to the following suggested examples of treaties conflicting peremptory norms:

"(a) a treaty contemplating an unlawful use of force contrary to the principles of the Charter, (b) a treaty contemplating the performance of any other act criminal under international law, and (c) a treaty contemplating or conniving at the commission of acts, such as trade in slaves, piracy or genocide, in the suppression of which every State is called upon to co-operate."

In addition, some members also mentioned other possible examples such as:

${ }^{92}$ Maurizio Ragazzi, The Concept of International Obligations Erga Omnes, Oxford University Press, 2002, pg. 50.

${ }_{93}$ Ibid., pg. 50-53. Article 38, paragraph 1 of the ICJ Statute reads as follows: The court whose function, is to decide in accordance with international law such disputes as are submitted to it, shall apply: a) international conventions, whether general or particular, establishing rules expressly recognized by the contesting states; b) international custom, as evidence of general practice accepted as law; c) the general principles of law recognized by civilized nations; d) subject to the provision of Article 59, judicial decisions and teachings of the most highly qualified publicists of the various nations, as subsidiary means for the determination of rules of law. 
“acts which constitute crimes under international law; treaties violating human rights, the equality of States or the principle of self-determination were mentioned as other possible examples. "94

As was explained by Hubert, the representative of France during the United Nations Conference on the Law of Treaties, the ILC 'had shown extreme caution in its commentaries' by providing first for examples that were suggested (such as unlawful use of force, performance of acts considered criminal under international law, slavery, piracy or genocide) and examples 'mentioned' by 'some members' (including the equality of states) without specifically saying whether it had itself (the ILC) accepted the views expressed by some of its members. ${ }^{95}$ From the above, it is clear the principle of equality of states was only mentioned in the second line of examples that were "mentioned by some members". Whether or not the principle of equality of states could be regarded as an example of a jus cogens norm was resolved by the ILC when drafting the Articles on state responsibility in which the ILC did not include the principle of equality of states at all. The ILC stated that:

"those peremptory norms that are clearly accepted and recognized include the prohibitions of aggression, genocide, slavery, racial discrimination, crimes against humanity and torture, and the right to self-determination". ${ }^{96}$

Clearly there was no mention of the principle of equality of states in the examples of jus cogens norms enumerated above. This should not come as a surprise as it cannot be said that the principle of equality of states is a jus cogens norm of international law due to the fact that the principle of equality of states is an umbrella principle with a scope of application difficult to determine. In addition, if the principle of equality of states would had been recognized as a jus cogens norm, the legal implications resulting from that result would be serious for many IGOs. Namely, all the founding treaties of IGOs (as

\footnotetext{
${ }^{94}$ YBILC 1966, Draft Articles on the Law of Treaties with commentaries, pg. 248, par.3.

${ }^{95}$ United Nations Conference on the Law of Treaties, Second session, Vienna, 9 April-22 May 1969, Official Records, Summary records of the plenary meetings and of the meetings of the Committee of the Whole, A/CONF.39/1l/Add.l, pg. 93-94. It should be noted that also during the first session of the United Conference on the Law of Treaties there were also some references to the principle of equality of states as a peremptory norm by the representatives of Sierra Leone and Ghana. As stated by Cole, the representative of Sierra Leone, "article 50 of the draft (current article 53 of the VCLT) provided a golden opportunity to condemn imperialism, slavery, forced labour and all practices that violated the principle of the equality of all human beings and of the sovereign equality of States, by affirming the peremptory character of the rules of international law concerning fundamental human rights, the principle of self-determination and all the inviolable principles of the Charter, embodied, in particular, in Articles 2, 33, 51 and 103”. In similar lines, Dadzie, the representative of Ghana stated: "in the twentieth century, some of humanity's most bitter experiences had led it to recognize the peremptory character of an ever-increasing number of rules, such as the principles of self-determination and the sovereign equality of States, and the prohibition of genocide and slavery and its bastard son, racial discrimination”. See United Nations Conference on the Law of Treaties, First session, Vienna, 26 March-24 May 1968, Official Records, Summary records of the plenary meetings and of the meetings of the Committee of the Whole, A/CONF.39/11, pg. 301-302.

${ }^{96}$ YBILC 2001, Volume II, Part two, Draft articles on Responsibility of States for Internationally Wrongful Acts, with commentaries, pg. 85.
} 
IGOs are almost in absolute terms founded by treaties) that deviate from the principle of equality of states would be void. By this logic, this would have also included the UN Charter due to its deviation from the application of the principle of equality of states in the Security Council with the special position of the permanent five.

To sum up, although the principle of equality of states is an important principle of international law, it cannot be stated that it is a jus cogens norm. Such a conclusion is based in the fact that the principle of equality of states is not (as the wording of the VCLT notes) "accepted and recognized by the international community of States as a whole as a norm from which no derogation is permitted” as can be clearly seen by the deviations from the principle of equality of states in various IGOs.

\section{THE PRINCIPLE OF EQUALITY OF STATES: NON- DISCRIMINATION AND AFFIRMATIVE ACTION}

Another aspect of the principle of equality of states, again based on municipal law as well as international human rights conventions, is the principle of non-discrimination. This is logical, as any non-discrimination provision is related to the principles of equality and equal treatment which, if not upheld, result in discrimination.

The Oppenheim treatise under the chapter on equality of states has a special section on equality of states and non-discrimination. ${ }^{97}$ In that section it is stated that:

" $[D]$ iscrimination is widely regarded as undesirable, and in some particular respects a rule of non-discrimination may exist, within limits which are not clear. Thus a state party to a multilateral treaty may, as a reflection of its duty to perform treaties in good faith as well as of the equality of states parties to the treaty, be required to apply its terms equally to all other parties. In some circumstances particularly if there is a strong element of arbitrariness in the different levels of treatment accorded by one state to others, discrimination might constitute an abuse of rights. States also have the duty to co-operate with one another, irrespective of the differences in their political, economic... in order to promote...co-operation free from discrimination based on such differences. "98

Equality at its minimum relates to equal treatment and non-discrimination. There is no justification in granting the right to conduct that treats certain states less favorably in identical situations, resulting in inequality in rights and duties between states. In order to combat discrimination one of the measures available in municipal and international law is the measure of affirmative action. Affirmative action aims to ensure equality in situations where there is inequality or, if such affirmative action would not take place, inequality would most likely occur. One example of this in the field of international

${ }^{97}$ Jennings and Watts, Oppenheim's International Law, Ninth Edition, Volume I, Peace: Introduction and Part I, Published by Addison Wesley Longman, 1997, pg. 376-379.

${ }^{98}$ Ibid., pg. 377. 
organizations law is the "special and differential treatment" given to developing countries by WTO Agreements. The differential treatment, which is a type of affirmative action, can facilitate substantive equality and finds its uses in a range of levels: solidarity, convergence of interests, proportional response to problems based on capacity to respond (for example, environmental issues), and implementation of international law. ${ }^{99}$ Differential treatment, similar to preferential treatment in terms of results, does not seek to change the rules or establish a new legal order, but it seeks to achieve more equitable results in the existing legal order. ${ }^{100}$

\section{THE MEANING OF THE PRINCIPLE OF EQUALITY OF STATES IN INTERNATIONAL LAW}

In scholarly reviews there are different approaches to the meaning of the principle of equality of states ranging from: "equality before the law" to "equal capacity for rights and obligations". ${ }^{101}$ For example, according to Dickinson, the notion of equality of states has two basic meanings: first, equal protection of the law (or as equality before the law) and second, which is the mainstream idea of the meaning of the principle in international law, it is understood as equal capacity for rights. ${ }^{102}$ For Dickinson, the meaning of the principle of equality of states is "equality of capacity for rights" unless stated otherwise. ${ }^{103}$ Similarly, Kelsen defines the meaning of the principle of equality of states as the "equality of capacity for duties and rights". ${ }^{104}$

According to Broms, the principle of equality of states in international law generally means:

\footnotetext{
99 Philippe Cullet, Differential Treatment in International Law: Towards a New Paradigm of Inter-state Relations, 10 Eur. J. Int'l. L. 549 (1999), pg. 558-564.

${ }^{100}$ Ibid., pg. 552. According to Cullet, the differential treatment is important for: bringing substantive equality in a system where still the idea of formal equality may be equated with justice, fostering cooperation among states, and providing for an incentive to better implement obligations, see pg. 552-553.

${ }^{101}$ Some even make the distinction between equality of the law requiring from the legislator to have equality as criteria and not make arbitrary distinctions as well as equality before the law requiring equal application of the law, see Ulrich K. Preuß, Equality of States-Its Meaning in a Constitutionalized Global Order, 9 Chi. J. Int'l. L. 17 (2008-2009), pg. 24.

${ }^{102}$ Edwin DeWitt Dickinson, The Equality of States in International Law, Harvard University Press, 1920, pg. 3-4. Dickinson's book is based on the PhD thesis he wrote at Harvard University in 1918. When referring to the opinions of the modern publicists of his time, presumably end of the XIX and the beginning of the XX century he refers to the definition by Calvo's Dictionary of equality as a good extract of the writings of the time stating that "equality is one of the natural and primitive rights of nations. It is the right by virtue of which every sovereign State may demand that another State shall not assume more extensive rights, in their mutual relations, that it enjoys itself, and shall not free itself from any of the obligations imposed upon all. The equality of sovereign States is a generally recognized principle of public law. It has twofold consequence in that it attributes to all States the same rights and imposes upon the reciprocally the same duties.” pg. 100.

${ }^{103}$ Edwin DeWitt Dickinson, The Equality of States in International Law, Harvard University Press, 1920, pg. 5 .

${ }^{104}$ Hans Kelsen, The Principle of Sovereign Equality of States as a Basis for International Organization, 53 Yale L. J. 207 (1943-1944), pg. 208-209.
} 
"either equality before the law or equality of rights and duties of States, the latter sometimes also expressed as equality of capacity for rights and duties". ${ }^{105}$

Broms seems to give the same meaning to equality of rights and duties with the equality of capacity for rights and duties.

If these interpretations are analyzed, under equality before the law, again by analogy, it is understood that if men are equal before the municipal law, states are equal before international law. On the other hand, under equal capacity for rights and duties, it is understood that inherent in their status of belonging to the category of states (as primary subjects of international law), any state has the same opportunity as all other states to acquire rights and to fulfill duties. State sovereignty in relation to other states is reflected in the formal equality of states. ${ }^{106}$

In relation to the meaning of the principle of state equality, the Oppenheim treatise taking many of the criticisms on board, states:

"Although the abstract principle of state equality is open to certain objections when pressed to extremes, and although it is sometimes departed from in circumstances which require account to be taken of undeniable inequalities in political and economic power (as with the permanent membership of certain major states in the Security Council and their so-called power of veto over certain decisions of the Council, even though the Charter of the United Nations is professedly based on the principle of "sovereign equality" of states) the principal of juridical equality is formally established as one of the basic principle of international law."107

From what is stated it seems that two points deserve more attention. First, the fact that the principle of equality of states was not applied in the case of the permanent membership in the Security Council may be understood as an exception from the rule. Second, the principal of juridical equality is formally established as one of the basic principles of international law.

Based on the various meanings of the principle of equality of states discussed so far, it seems that at times, instead of focusing on the simple meaning of the wording of the principle, namely "the principle of equality of states", authors are using a more acceptable wording to reflect the difficulties in the application of the principle of equality of states in international law. The interpretation that the principle of equality of states means equality before the law seems reasonable and acceptable only on the condition that the law is not arbitrary.

105 Bengt Broms, The Doctrine of Equality of States as Applied in International Organizations, Vammala Kirjapaino, 1959, pg. 16.

${ }^{106}$ Henry G. Schermes, Niels M. Blokker, International Institutional Law: Unity Within Diversity, Fourth Revised Edition, Martinus Nijhoff Publishers, 2003, pg. 9.

107 Jennings and Watts, Oppenheim's International Law, Ninth Edition, Volume I, Peace: Introduction and Part I, Published by Addison Wesley Longman, 1997, pg. 339-340. 
On the other hand, the interpretation that the principle of equality of states means "equal capacity for rights and duties" is a substitute arguing that all states have the same equal capacity for rights and obligations but "somehow" some states acquire more rights than others. While this may be true in certain instances, it is not a substitute to the principle of equality of states. This wording at times may legitimize situations when some states (as in the Security Council) have more rights than the rest. The principle of equality of states in international law means that every state is equal in its relations to other states. It does not mean that states are equal in any power determining parameters. The principle of equality of states is not a principle of equally powerful states, but a principle of equality in relations between states.

Having said this, however, one has to have in mind that perfect equality is a utopia and that it is due to the differences between states and existing inequalities that the principle of equality of states is established. There is a need for the existence of the principle of equality of states because there are inequalities between states and the principle of equality of states can go a long way in addressing these inequalities.

In fact, as will be discussed in the next chapter, the meaning of the principle of equality of states in international organizations is not as ambiguous as in international law. Unlike the general perception and discussions in legal doctrine about the various interpretations, the principle of equality of states in international organizations amounts to equality of rights and duties. This is to a certain degree facilitated by the scope of the principle of equality of states in international organizations which is much more limited and measurable than in international law.

\section{VIII.CONCLUSION}

The principle of equality of states is a recognized and well established principle of international law. It evolved by analogy from the ideal and legal principle of equality of men in municipal law into the principle of equality of states in international law. In legal doctrine authors such as Oppenheim, Brownlie, Cassese, and Shaw consider the principle of equality of states as one of the most important principles of international law.

A number of international law instruments refer to it: such as the Montevideo Convention on Rights and Duties of States, the Declaration on Principles of International Law concerning Friendly Relations and Co-operation among States, and the Charter of Economic Rights and Duties of States. Moreover, the Vienna Convention on the Representation of States in their Relations with International Organizations of a Universal Character refers to the principle of sovereign equality of states as a basic principle on which the convention was drafted. The principle of equality of states has not acquired the status of a jus cogens norm of international law due to the fact that it is not (as the wording of the VCLT notes) "accepted and recognized by the international community of States as a whole as a norm from which no derogation is permitted". This can be clearly seen from the deviations from the principle of equality of states in various IGOs. 
There is a debate between scholars on the meaning of the principle of equality of states. The meaning of the principle of equality of states in international law is usually defined either as equality before the law or as equal capacity for rights and obligations. The principle of equality of states in international law means that every state is equal in its relations to another. It does not mean that states are equal in any power determining parameters. It is not a principle of equally powerful states, but a principle on equality in relations between states. 


\section{CHAPTER II \\ THE PRINCIPLE OF EQUALITY OF STATES IN IN- TERNATIONAL ORGANIZATIONS}

\section{INTRODUCTION}

The principle of equality of states has established itself in international law and subsequently is applicable to the law of international organizations or to international organizations. In fact, as Kooijmans noted, the principle of equality of states "arose with renewed vigour and in a more concrete shape than ever before" with the establishment of an organization of a permanent character having as its members the majority of states. ${ }^{108}$

The International Court of Justice in the Advisory Opinion on the Interpretation of the Agreement of 25 March 1951 between the World Health Organization (WHO) and Egypt made it clear that international organizations are bound by international law by stating:

"International organizations are subjects of international law and, as such, are bound by any obligations incumbent upon them under general rules of international law, under their constitutions or under international agreements to which they are parties."109

As will be discussed in this chapter, the principle of equality of states has found its place in the highest legal sources of international organizations, their founding treaties. In some, references are direct and in some indirect. In addition, there are national constitutions which limit the membership of their states in international organizations on conditions of respect of the principle of equality and reciprocity. This chapter will discuss the evolution, presence and meaning of the principle of equality of states in the law of international organizations while the various dimensions of the review of the application of the principle of equality of states in international organizations will be discussed in the following chapter.

${ }^{108}$ Peter H. Kooijmans, The Doctrine of Legal Equality of States: An Inquiry Into the Foundations of International Law, A. W. Sythoff, 1964, pg. 3.

${ }^{109}$ ICJ Report 1980, at 89-90, Also see Catherine Brölmann, A Flat Earth? International Organizations in the System of International Law, 70 Nordic J. Int’l. L. 319 (2001), pg. 324. 


\section{INTERNATIONAL ORGANIZATIONS AND THE PRINCIPLE OF EQUALITY OF STATES}

As stated in the previous section, the principle of equality of states applies to international organizations. Therefore, initially one has to address the question of what is understood by an international organization. This is important because the focus here is in the application of the principle of equality of states in international organizations and not in international law. As surprising it may be, there is no common understanding or a generally accepted definition on international organizations. A good starting point seems to be the answer provided by Klabbers to a basic question:

"What exactly is an international organization?...The short answer is, quite simply, that we do not know. We may in most cases, be able to recognize an international organization when we see one, but it has so far appeared impossible to actually define such organizations in a comprehensive way. " 110

The cases of the GATT and the OSCE which due to their questioned legal personality are not considered de jure international organizations illustrate the difficulty of answering such a simple question. ${ }^{111}$ The fact that international organizations are different makes a general theoretical framework encompassing a detailed and an all inclusive definition applicable to all of them so far impossible. The literature in this field discusses a number of definitions. For example, according to the International Law Commission, the term international organization means an:

“organization established by a treaty or other instrument governed by international law and possessing its own legal personality."

According to Schermers and Blokker international organizations are defined as:

"forms of cooperation founded on an international agreement usually creating a new legal person having at least one organ with a will of its own, established under international law."113

\footnotetext{
${ }^{110}$ Jan Klabbers, An Introduction to International Institutional Law, Second Edition, Cambridge University Press, 2009, pg. 6. This sound strikingly similar to the question posed by Hart: what is law? The answer is rather similar as well, there is great difficulty in answering this seemingly such a simple question. See H. L. A. Hart, The Concept of Law, Oxford University Press, Second Edition, 1994.

${ }^{111}$ OSCE is generally considered not possessing international legal personality, see Tarcisio Gazzini, 'Personality of International Organizations’ in Jan Klabbers and Åsa Wallendahl, Editors, Research Handbook on the Law of International Organizations, Edward Elgar Publishing Limited, 2011, pg. 40. GATT on the other hand is generally considered to have been $a$ de facto but not a de jure international organization, see Peter Van den Bossche, Werner Zdouc, The Law and Policy of the World Trade Organization: Text, Cases and Materials, Third Edition, Cambridge University Press, 2013, pg. 76.

112 See YBILC 2011, vol. II, Part Two, Draft articles on the Responsibility of International Organizations Article 2, subparagraph (a).
} 
On the other hand, in similar terms, there are authors that take another approach by focusing not on a general definition but rather on the existing elements of international organizations. For example, Klabbers defines international organizations through the following elements: created between states, on the basis of a treaty and with an organ with a distinct will. ${ }^{114}$ Klabbers further explains that there are exceptions, for example, it is not only states establishing international organizations, or the fact that besides international treaties, international organizations are also established through Resolutions. Similarly, the Sixth Edition of the Bowett's law of international institutions defines international organizations by focusing on their characteristics. It takes on board some of the main exceptions from the general perceptions by stating that:

"membership must be composed of states/and or other international organizations; it must be established by treaty or other instrument governed by international law, such as a resolution adopted in an international conference; it must have an autonomous will distinct from its members and be vested with legal personality." 115

To sum up, while there is a debate about whether some IGOs are considered as such, there is also a general theoretical framework for defining international organizations which recognizes the existence of many exceptions. It is not always the case that members of international organizations are states, that IGOs are always founded by a treaty, or that IGOs always have legal personality as well as other distinguishable features that are applicable to all IGOs. Without spending too much time on the various theoretical debates about ways how to define international organizations, it is satisfactory to say that the organizations to be reviewed by this book (the UN, the WTO, and the IMF) are without a doubt "recognized" as international organizations "when seen”.

\section{MEMBER STATES AND INTERNATIONAL ORGANIZATIONS}

A distinguished feature of the application of the principle of equality of states in international organizations is that it applies to member states. The word "member" originates from Latin word "membrum" meaning "part of the body". ${ }^{116}$ From this, one can by

\footnotetext{
${ }^{113}$ Henry G. Schermes, Niels M. Blokker, International Institutional Law: Unity Within Diversity, Fourth Revised Edition, Martinus Nijhoff Publishers, 2003, pg. 26. International organizations have three elements: they are founded by an international agreement, they should be a new legal person and be established under international law, see pg. 32-37.

114 Jan Klabbers, An Introduction to International Institutional Law, Second Edition, Cambridge University Press, 2009, pg. 7-12.

115 Philippe Sands and Pierre Klein, Bowett's Law of International Institutions, Sixth Edition, Sweet \& Maxwell, 2009, pg. 15.

${ }^{116}$ Niels Blokker, International Organizations and Their Members, 1 Int'l. Org. L. Rev. 139 (2004), pg. 139. On this occasion, perhaps it should be added that while this simple translation from Latin is correct, however, it still may leave some truth unrevealed. Members may be as mentioned "parts or limbs of the body" but they
} 
reason draw the conclusion that the "body" refers to the international organization and the "parts" refers to its members. This is in perfect line with the fact that international organizations are created, function and may be terminated by their members.

International organizations have different policies on membership which in most cases are primarily regulated through their constituent treaties and subsequently by other sources of law as well as practice of a particular IGO. The meaning of the concept of membership in international organizations and the substantive and procedural legal framework are of great importance for the application of the principle of equality of states in membership in international organizations. This determines the conditions to join the IGO, whether it has an open- or closed-door policy, whether there are differences between original and non-original members, representation and voice of members, decision-making processes and opportunities to influence decision-making. While some international organizations are of a universal character such as the United Nations which is the most typical international governmental organization of such a nature, others may place limitations for accession of new members maintaining closed-door policy. For example, the European Union, the Organization of African States or the Organization of American States_(OAS), all of which maintain limitations based on geography. ${ }^{117}$ Other international organizations may maintain limitations of another nature. For example, OPEC has petroleum exportation as criterion for membership, NATO focuses on common political and ideological values and the Organisation international de la Francophonie is based on the use of the French language. ${ }^{118}$ Existing membership in an international organization may be the condition for membership in another international organization as in the case with membership to the World Bank which is conditioned on existing membership in the International Monetary Fund.

Members have strong ties based on various factors (ideology, religion, geography, history), status (oil exporting as in OPEC), combination (being oil exporter and an Arab state as in the Organization of Arab Petroleum Exporting Countries), or have a specific aim as was the case with the United Nations in the beginning composed of the coalition fighting Nazi Germany and Imperial Japan. ${ }^{119}$ Universal organizations have heterogeneous membership while the closed ones have a more homogenous membership. ${ }^{120}$

also may tend to have a will of their own and act separately. If members have a distinct will, then they seem to be more than a part of the body. In fact, as noted by Dunoff, it is not sufficient to view XXI century international organizations only as a fora where states pursue their interest because international organizations also pursue their own policies as autonomous actors of world politics, see Jeffrey L. Dunoff, Is Sovereign Equality Obsolete? Understanding Twenty-First Century International Organizations, 43 Neth. YBIL 99 (2013), pg. 102-103.

117 Jan Klabbers, An Introduction to International Institutional Law, Second Edition, Cambridge University Press, 2009, pg. 22.

${ }^{118}$ Ibid., pg. 22-23.

119 Konstantinos D. Magliveras, 'Membership in international organizations' in Jan Klabbers and Åsa Wallendahl, Editors, Research Handbook on the Law of International Organizations, Edward Elgar Publishing Limited, 2011, pg. 85.

${ }^{120}$ Henry G. Schermers \& Niels M. Blokker, International Institutional Law, Fifth Revised Edition, Martinus Nijhoff Publishers, 2011, pg. 52-54. 
In most international organizations membership is an opportunity given only to states. This is the case, for example, for the United Nations and the majority of its specialized agencies, the European Union, the European Free Trade Area (EFTA), the $\mathrm{AU}$, the OAS, and the Council of Europe (CoE). ${ }^{121}$

In the overwhelming majority of cases, statehood of an entity is not a contested issue. However, there are cases, when it is important to establish if an entity is a state and subsequently whether the principle of equality of states applies to it as well. The fact that there is no generally accepted definition of a state in international law makes it more difficult to resolve such cases. The closest definition on the notion of a state in international law is given by the Montevideo Convention on the Rights and Duties of States stating that:

"the state as a person of international law should possess the following qualifications: a permanent population, defined territory, government, capacity to enter into relations with other states. "122

In addition to the Montevideo Convention, the Badinter Arbitration Committee dealing with the dissolution of the former ex-Yugoslavia stated that:

"the state is commonly defined as a community which consists of a territory and a population subject to an organized political authority, that such a state is characterized by sovereignty." 123

Except for states, membership in international organizations is/was also an opportunity for separate customs territories ${ }^{124}$, international organizations ${ }^{125}$, dominions or colonies $^{126}$, republics within federations not possessing state sovereignty ${ }^{127}$ and even protec-

\footnotetext{
121 Philippe Sands and Pierre Klein, Bowett's Law of International Institutions, Sixth Edition, Sweet \& Maxwell, 2009, pg. 538.

${ }^{122}$ Montevideo Convention on the Rights and Duties of States, 1933, Article 1.

${ }^{123}$ Arbitration Commission of the Conference on Yugoslavia, Opinion No.1, Point 1 (b), 1990.

${ }^{124}$ Such as the case with the WTO allowing accession of States and Separate Customs Territories, see Article XII of the Marrakesh Agreement Establishing the World Trade Organization.

${ }^{125}$ Such is the case again with the WTO having the European Union (until December 2009 still referred to as 'European Communities') as a member. On accession to the WTO see Article XII of the Marrakesh Agreement Establishing the World Trade Organization providing for the possibility of accession only for states and separate customs territories. However the European Communities became a member according to Article XI of the Marrakesh Agreement Establishing the WTO, thus Article XII does not apply to this case. The European Union is also a member of the Food and Agriculture Organization ('FAO'). For the legal basis allowing international organizations to be a member of the FAO, see Article 2. of the Constitution of the FAO.

${ }^{126}$ Under the British Empire original membership of the League of Nations was granted to: Canada, Australia, South Africa, New Zealand, India each having separate votes. See Annex of the Covenant of the League of Nations listing the original members of the League of Nations.

${ }^{127}$ Belarus and Ukraine were granted original membership in the United Nations in 1945 while being Republics of the Soviet Union and were not considered states until their independence with the dissolution of the Soviet Union in the 1990s. The acquisition of original membership of the UN by Belarus and Ukraine is considered to be an exception to the rule that only states can join the United Nations. On the acquisition of membership in the UN, see Chapter IV, below, pg. 127-153.
} 
torates ${ }^{128}$. The increasing trend in the last 15 years is for international organizations to join other international organizations (for example the European Community joining the FAO in 1991, the World Customs Organization 2007). ${ }^{129}$

It is interesting that even in terms of terminology of using the notion "state", which is relevant to this inquiry (as the principle of equality is applicable to states) there is no unanimity between international organizations. International organizations besides using the notion of a "state" to denominate their members, they also among others use notions such as "countries", "nations", or "contracting parties". The practical meaning and application of these notions varies from one organization to another and at times may be complex and confusing.

The League of Nations spoke of "High Contracting Parties" while it referred to its members as "Signatories" and "States" and at the same time allowed admission of "any fully self-governing State" as well as the admission of any "dominion or colony" which quite naturally were not "states". ${ }^{130}$ On the other hand, while the United Nations, the World Health Organization, International Labor Organization, International Development Association (IDA), and the United Nations Educational Scientific and Cultural Organization (UNESCO) are open to "states", other organizations such as the International Bank for Reconstruction and Development (IBRD), International Monetary Fund, and International Finance Corporation (IFC) are open to "countries", and there are such organization as the Food and Agriculture Organization that are open to "nations". ${ }^{131}$ In the WTO, according to the Marrakesh Agreement Establishing the WTO, the terms "country" or "countries" also include WTO Members that are not states, but "separate customs territories" (and an international organization). ${ }^{132}$

\section{THE EVOLUTION OF THE PRINCIPLE OF EQUALITY OF STATES: FROM INTERNATIONAL CONFERENCES TO THE LEAGUE OF NATIONS}

Membership in international organizations is a dynamic concept. It has evolved over time and it is as old as international organizations are. There is no blue print developed out there which would serve as a model, based on which IGOs and their membership policies developed. This is the result of a simple fact: the evolution of international

\footnotetext{
${ }^{128}$ The Philippines while being a protectorate of the United States achieving independence in 1947 were granted the status of original member of the United Nations in 1945.

${ }_{129}$ Konstantinos D. Magliveras, 'Membership in international organizations' in Jan Klabbers and Åsa Wallendahl, Editors, Research Handbook on the Law of International Organizations, Edward Elgar Publishing Limited, 2011, pg. 84, footnote 1, pg. 102.

${ }^{130}$ See Covenant of the League of Nations, Article 1, para. 2.

${ }^{131}$ Ebere Osieke, Admission to Membership in International Organizations: The Case of Namibia, 51 Brit. Y. B. Int'l. L. 189 (1980), pg. 189-190. Also see footnote 1 for reference on legal basis: Article 3 and 4 of the UN Charter, Article 3, 5, 6 of the Constitution of the WHO, Article 1 (2) of the ILO Constitution, Article XI of the IDA Constitution, Article 2 of the UNESCO Constitution, IBRD Section 2, IMF Article 1, IFC Article IX and FAO Article 2 of the Constitution.

${ }^{132}$ See the Explanatory Notes of the Marrakesh Agreement Establishing the World Trade Organization.
} 
organizations was conditioned more by the specific needs and functions of each international organization then by the existing theoretical frameworks on the matter. However, each subsequent organization had the previous experiences to learn from. This tension between comparing different organizations and using the past experiences seems best described by Blokker when he states:

"the development of new institutional rules in practice often is characterized by a tension between the apples-and-oranges argument on the one hand, and the why-reinvent-the-wheel argument on the other. "133

With regard to the reinventing the wheel argument, it seems of great interest to see the first ever application of the principle of equality of states in membership in international organizations. This is important for two reasons, namely to establish: (1) whether there is a precedent; and (2) whether the principle of equality of states as a general principle of international law was applied to international organizations from the moment international organizations were established. It would be logical to assume that this was the case with the application of the principle of equality in the first international organization ever created. That seems to be the crucial case in the history of the evolution of the principle of equality of states in international organizations.

However, before embarking on that journey, due credit must be given to the forerunners of international organizations, the international conferences for introducing the principle of equality of states and building the foundations for its development in international organizations. It is an historical fact that chronologically the principle of equality of states in international law is considered to have been established in the XVII century with the Peace of Westphalia. ${ }^{134}$ Another fact of history is that the application of the principle to international organizations was not possible until the XX century with the establishment of the first political international organizations. According to Amersinghe, the XIX century was the era of preparations while the XX century the era of establishment of international organizations. ${ }^{135}$ In between the XVII century and the appearance of international organizations in the XX century international conferences existed and they are considered to be the forerunners of international organizations.

The international community of the time was not yet sufficiently developed to create international organizations. Instead, it used the international conferences as ad hoc

\footnotetext{
${ }^{133}$ Niels Blokker, Comparing Apples and Oranges? Reinventing the Wheel? Schermers' Book and Challenges for the Future of International Institutional Law, 5 Int'l. Org. L. Rev. 197 (2008), pg. 201.

${ }^{134}$ See Herbert Weinsohel, The Doctrine of the Equality of States and its Recent Modifications, 45 Am. J. Int'l. L. 417 (1951), pg. 418; Goebel, Julius, The Equality of States, 23 Colum. L. Rev. 247 (1923), pg. 259; Gerry Simpson, Great Powers and Outlaw States: Unequal Sovereigns in the International Legal Order, Cambridge University Press, 2004, pg. 9; Edwin DeWitt Dickinson, The Equality of States in International Law, Harvard University Press, 1920, pg. 232-233. Although Dickinson argues that this does not mean "equal capacity for rights”.

${ }^{135}$ C. F. Amerasinghe, Principles of the Institutional Law of International Organizations, Second Edition, Cambridge University Press, 2005, pg. 5.
} 
gatherings and meetings of states to resolve various issues. ${ }^{136}$ No one can speak of international organizations in that phase of development of the community of nations.

The forerunners of IGOs, the various international conferences, developed many rules including the principle of equality of states. According to this principle, no state can claim privileges in rank or in the decision-making. ${ }^{137}$ There is no doubt that at these ad hoc conferences the role of the principle of equality of states was crucial and applied even to most extreme as decisions were adopted by unanimity, not by majority vote. ${ }^{138}$ According to Zamora, two important truths are exemplified in early conferences: equal voice in conference proceedings or the doctrine of sovereign equality of states and the requirement for unanimity i.e. that states cannot be bound without their consent. ${ }^{139}$ Similarly, according to Sohn, the structure of the different international organizations existing in the past was based on two principles: equality of representation and unanimity. ${ }^{140}$ For Broms, the application of the principle of equality of states in various conferences varies, although, at times, such as at the Hague Conferences, the principle was applied in an absolute manner by requiring unanimity on all questions. ${ }^{141}$

In general terms, it can be stated that the adherence to the principle of equality in these conferences was strict, all states had equal votes and the unanimity requirement played a seriously restrictive role. ${ }^{142}$ Besides being ad hoc, international conferences had a number of other flaws. Some of them are quite relevant for this study, such as the fact that participation depended on invitations by the host state and no notion of membership and right to participation existed. ${ }^{143}$ Therefore, though fundamental to the establishment of the principle of equality of states, international conferences were not able to deliver a proper solution for the ongoing difficulties which required continuous participation and engagement of states.

With regard to international organizations, it should be noted that although there were IGOs of a technical function before, one can only speak of the origins of international organizations in the beginning of the XX century with the establishment of the League of Nations (LN), the first political international organization coming to life in

${ }^{136}$ Examples of international conferences determining in great length the developments of the world were the ad hoc conferences such as the Peace of Westphalia of 1648, the Congress of Vienna in 1815, and the Treaty of Versailles of 1919 as well as many others.

137 Peter R. Baehr and Leon Gordenker, The United Nations: Reality and Ideal, Fourth Edition, Palgrave Macmillan, 2005, pg. 7.

${ }^{138}$ C. F. Amerasinghe, Principles of the Institutional Law of International Organizations, Second Edition, Cambridge University Press, 2005, pg. 2.

${ }^{139}$ Stephen Zamora, Voting in International Economic Organizations, 74 Am. J. Int'l. L. 566 (1980), pg. 573.

${ }^{140}$ Louis B. Sohn, Weighting of Votes in an International Assembly, 38 Am. Pol. Sci. Rev. 1192 (1944), pg. 1192.

${ }^{141}$ On the application of the principle of equality of states to international conferences prior to the League of Nations see Bengt Broms, The Doctrine of Equality of States as Applied in International Organizations, Vammala Kirjapaino, 1959, pg. 82-116.

142 Philippe Sands and Pierre Klein, Bowett's Law of International Institutions, Sixth Edition, Sweet \& Maxwell, 2009, pg. 3.

${ }^{143}$ C. F. Amerashinghe, International Institutional Law - A Point of View, 5 Int'l. Org. L. Rev. 143 (2008), pg. 143-150. 
1919. ${ }^{144}$ The League of Nations was established under the initiative of the US President Woodrow Wilson. President Wilson in his famous Fourteen Points plan presented to US Congress on January 8, 1918 called for the creation of the League of Nations. Out of the Fourteen Points, the last Point is the most relevant to the principle of equality of states and its application in international organizations. It stated:

"A general association of nations must be formed under specific covenants for the purpose of affording mutual guarantees of political independence and territorial integrity to great and small states alike.,"145

Furthermore, when referring to Germany of the time, having in mind the principle of equality of states, President Wilson stated:

"we wish her (Germany) only to accept a place of equality among the peoples of the world, - the new world in which we now live, - instead of a place of mastery. ${ }^{146}$

The Covenant of the League of Nations was agreed to by the majority of the states of the time and the League was successfully established in 1919. Paradoxically, the United Stated did not join the League of Nations, the first international organization initiated primarily by the US President. Moreover, the US did not join the League of Nations despite the fact that the first meeting of the Assembly and of the Council according to the Covenant was to be summoned by the President of the United States. ${ }^{147}$ Such an honor to a state, with such a specific reference seems to be unprecedented in any other international organization.

With regard to the principle of equality of states, it is important to point out the fact that there was no direct reference to the principle of equality of states in the Covenant of the League of Nations. However, even without direct references to the principle of equality of states in the Covenant, the League of Nations was important for the development of the principle of equality of states through its institutional framework and decision-making.

The institutional framework of the LN was provided by Article 2 of the Covenant which established the organs of the League of Nations. It stated that:

"The action of the League under this Covenant shall be effected through the instrumentality of an Assembly and of a Council, with a permanent Secretariat." ${ }^{148}$

\footnotetext{
144 There were other international organizations established prior to this date as was the case with the various river commissions, the International Telegraphic Union in 1865, the Universal Postal Union of 1874, the Metric Union in 1875, but were more of a limited and technical function.

${ }^{145}$ Woodrow Wilson’s “Fourteen Points” Speech, January 8, 1918, Point XIV.

${ }^{146}$ Woodrow Wilson’s “Fourteen Points” Speech, January 8, 1918.

${ }^{147}$ See The Covenant of the League of Nations, Article 5, para. 3.

${ }^{148}$ The Covenant of the League of Nations, Article 2.
} 
The Assembly represented a plenary organ of the LN while the Council the non plenary organ. The one-seat one-vote rule in the Assembly represented political equality. ${ }^{149}$ On the other hand, the primacy of the Great Powers having a permanent seat in the Council of the League of Nations was considered a definite legal inequality. ${ }^{150}$ Such a division between members was not in compliance with the principle of equality of states due to the inequality of representation between the members of the LN.

However, except in the Assembly, the idea of equality of states was part of the League of Nations in the form of unanimous decision-making foreseen by Article 5 of the Covenant which provided for the general rule of decision-making. It stated that:

"Except where otherwise expressly provided in this Covenant or by the terms of the present Treaty, decisions at any meeting of the Assembly or of the Council shall require the agreement of all the Members of the League represented at the meeting."151

It should be noted however, that unanimity was required only for substantive matters. For procedural matters, as well as for appointments of Committees to investigate specific issues, the second paragraph of Article 5 allows majority decision-making in the Assembly and the Council.

The Covenant of the League of Nations was considered a victory for the smaller states due to the fact that the principle of equality of states found embodiment in the unanimity rule of Article $5 .^{152}$ Actually, according to some views, one of the main reasons that the US did not join the League had to do with the idea of equality of states which was a basic principle of the Covenant. ${ }^{153}$ Such a view does not seem to be supported by Winston Churchill. Although not specifically referring to the principle of equality of states, (but to the principles of the League of Nations which contained unanimity decision making) at University of Zurich in September 1946, Churchill stated:

"The League of Nations did not fail because of its principles or conceptions. It failed because these principles were deserted by those States who had brought it into being." 154

To sum up, although there were no direct references to the principle of equality of states in the first political international organization, the League of Nations, it was clearly an

\footnotetext{
${ }^{149}$ P. J. Baker, The Doctrine of Legal Equality of States, 4 Brit. Y. B. Int'l. L. 1 (1923-1924), pg. 17.

${ }^{150}$ Ibid., pg. 16-17.

${ }^{151}$ Covenant of the League of Nations, Article 5, para. 1.

${ }^{152}$ Herbert W. Briggs, Power Politics and International Organization, 39 Am. J. Int'l. L. 664 (1945), pg. 669.

153 Talcott Williams, The Misleading Myth of the Equality of Nations, 96 Annals of the American Academy of Political and Social Science, The Place of the United States in a World Organization for Maintenance of Peace, 124 (1921), pg. 124.

${ }^{154}$ Speech of Sir Winston Churchill, Zurich, 19th September 1946, available online at http://assembly.coe.int/Main.asp?link=/AboutUs/zurich_e.htm, (visited May, 2013).
} 
underlying principle in its decision making (by requiring unanimity and the one-state one-vote rule). In addition, it should be noted that the historical circumstances at the time (in 1919) for the principle of equality of states were quite different. It is a fact that most of the development of the principle of equality of states in the form of its presence in international instruments, UN Charter and other treaties establishing international organizations or GA Resolutions developed decades later. Therefore, one may come to the conclusion that there was a relatively strong presence of the principle of equality of states in the League of Nations.

\section{THE PRINCIPLE OF EQUALITY OF STATES BEYOND THE LEAGUE OF NATIONS}

The formal "deficiency" of the League of Nations in not having any reference to the principle of equality of states was eventually addressed in the United Nations. The United Nations Charter in Article 2 states:

"The organization is based on the principle of sovereign equality of all its members." $" 155$

This provision of the Charter is the most frequently cited one with regard to the principle of equality of states. However, there are references to equality, equal rights in other provisions as well. They will be further discussed in the part dealing specifically with the UN. ${ }^{156}$

The UN is one major example. Moreover as shown in this book, direct references to the principle of equality of states can also be found in the founding treaties of other international organizations as well.

With even stronger words than the UN Charter, the Charter of the Organization of the American States in its Chapter IV, titled fundamental rights and duties of states, states:

"States are juridically equal, enjoy equal rights and equal capacity to exercise these rights, and have equal duties. The rights of each State depend not upon its power to ensure the exercise thereof, but upon the mere fact of its existence as a person under international law." 157

\footnotetext{
${ }^{155}$ UN Charter, Article 2, para. 1. By a "Member" the Charter means states, because as determined by the Charter, membership to the United Nations is open only to states.

${ }^{156}$ On the principle of equality of states in the UN Charter, see below, pg. 123-127.

${ }^{157}$ Charter of the Organization of the American States, Article 10. Signed in Bogota in 1948 and amended by the Protocol of Buenos Aires in 1967, by the Protocol of Cartagena de Indias in 1985, by the Protocol of Washington in 1992, and by the Protocol of Managua in 1993.
} 
It is obvious that the Charter of OAS recognizes the principle of equality of states and even goes one step further by even specifying that equality does not depend on the power of states but by the mere fact of their existence as such.

Also, the Statute of OPEC of 1961 directly refers to the principle of equality of states when stating:

"The Organization shall be guided by the principle of the sovereign equality of its Member Countries. ${ }^{\prime 158}$

The Helsinki Final Act ${ }^{159}$, the final act of the Conference on Security and Cooperation in Europe (CSCE) represents one of the fundamental instruments that led to the establishment of the Organization for Security and Cooperation in Europe (OSCE) $)^{160}$, places the principle of sovereign equality as its first principle. It states:

"The participating States will respect each other's sovereign equality and individuality as well as all the rights inherent in and encompassed by its sovereignty, including in particular the right of every State to juridical equality, to territorial integrity and to freedom and political independence... Within the framework of international law, all the participating States have equal rights and duties...They also have the right to belong or not to belong to international organizations, to be or not to be a party to bilateral or multilateral treaties including the right to be or not to be a party to treaties of alliance; they also have the right to neutrality. $" 161$

In similar lines, the Charter of ASEN as its first principle states the:

“(a) respect for the independence, sovereignty, equality, territorial integrity and national identity of all ASEAN Member States."

Finally, also the Vienna Convention on the Representation of States in their Relations with International Organizations of a Universal Character refers to the principles of sovereign equality of states as a basic principle on which the convention was drafted. ${ }^{163}$

To sum up, references to the principle of equality of states as shown from the examples above are present in the founding treaties of international organizations. While the examples shown are not exhaustive and do not cover all existing international

\footnotetext{
${ }^{158}$ OPEC Statute, Article 3.

159 The Helsinki Final Act, 1975.

${ }^{160}$ Based on the Helsinki Final Act, the institutional process for the establishment of the OSCE was laid down with the Charter of Paris for a New Europe in 1990. See OSCE web page at: http://www.osce.org/mc/43197, (visited March 2013).

${ }^{161}$ Helsinki Final Act, 1975, Principle I of the Declaration of the Principles Guiding Relations between the participation states.

${ }_{162}$ ASEAN Charter, Article 2, para. 2, (a).

${ }^{163}$ Vienna Convention on the Representation of States in their Relations with International Organization of a Universal Character, Preamble, para. 2.
} 
organizations they yet represent a strong argument in favor of the presence and influence of the principle of equality of states in international organizations.

\section{THE PRINCIPLE OF EQUALITY OF STATES IN INTERNATIONAL ORGANIZATIONS: A CONSTITUTIONAL OBLIGATION FOR STATES}

A fact that perhaps may be even more interesting and intriguing is that in some states, national constitutions require conditions of equality and reciprocity to be upheld when joining an international organization. This makes the application of the principle of equality of states not only an obligation under international law but an obligation of constitutional (municipal) law as well. National constitutions provide the authority for individual states to join international organizations and transfer part of their sovereignty. Such constitutional provisions, at times, may condition joining international organizations by reciprocity, equal treatment as well as proportional responsibility by all members. ${ }^{164}$ For example, Article 11 of the Constitution of Italy states:

"Italy agrees, on conditions of equality with other States, to the limitations of sovereignty that may be necessary to a world order ensuring peace and justice among the Nations. Italy promotes and encourages international organizations furthering such ends. "165

From the second sentence it is clear that reference to equality with other states is made with regard to limitations of sovereignty and adherence to international organizations. Similarly to the Italian constitution the constitution of another EU member state, Greece, in addition to equality requires conditions of reciprocity when joining an international organization. Article 28 of the Greek Constitution states:

"Greece shall freely proceed by law passed by an absolute majority of the total number of Members of Parliament to limit the exercise of national sovereignty, insofar as this is dictated by an important national interest, does not infringe upon the rights of man and the foundations of democratic government and is effected on the basis of the principles of equality and under the condition of reciprocity. "166

Whether or not, these countries have respected their constitutional obligation to respect the principle of equality when joining international organizations is another matter. It is beyond the focus of this book to draw such concrete and specific conclusions. Perhaps

\footnotetext{
164 Magdalena M. Martin Martinez, National Sovereignty and International Organizations, Kluwer Law International, 1996, pg. 67-68. References to some of the specific Constitutions given on footnote 12.

${ }^{165}$ Constitution of the Italian Republic, Article 11.

${ }^{166}$ Constitution of Greece, Article 28.
} 
some of the conclusions drawn from this research with regard to the specific organizations reviewed may shed some lights whether or not the constitution of Greece and Italy were violated when joining international organizations that were not in compliance with the principle of equality of states.

\section{THE MEANING OF THE PRINCIPLE OF EQUALITY OF STATES IN INTERNATIONAL ORGANIZATIONS}

As mentioned, there are at least two basic interpretations of the meaning of the principle of equality of states in international law: equal capacity for rights or equality before the law. However, compared to international law, there is not much of a debate on the meaning of the principle of equality of states in international organizations. What is usually stated in the literature are the situations that are considered to represent deviations from the principle of equality of states in international organizations. Therefore, unlike the debate on the meaning of the principle of equality of states in international law, the debate on the meaning of the principle of equality of states in international organizations is rather simple. The focus is much more limited, and the rights and obligations are more obvious and measurable. The principle of equality of states in international organizations means equality of rights and duties of member states of international organizations. The principle of equality dictates same rights and duties without discrimination for all members. ${ }^{167}$ While it is clear that the principle of equality of states in IGOs requires equality in rights and obligations of states, the difficulty (as stated by Broms) in reviewing the application of the principle of equality of states in IGOs is to find out how much are states equal in their rights and duties in international organizations. Or, how much equality of states there is between states as a result of their equal capacity for rights. ${ }^{168}$

One caveat that may lead to confusion with regard to the meaning of the principle of equality of states relates to its emanation in the form of "sovereign equality" in the UN Charter. According to Kelsen, the notion of "sovereign equality" probably means sovereignty and equality as they are qualities considered to be connected with one another. ${ }^{169}$ State sovereignty in relations to other states is reflected in the formal equality of states. ${ }^{170}$ However, "sovereign equality" at times may implicate additional complexity to the concept of equality of states in IGOs. While the concept of "sovereign equality" is arguably derived from the principle of equality of states, it is not identical to

167 Konstantinos D. Magliveras, 'Membership in international organizations' in Jan Klabbers and Åsa Wallendahl, Editors, Research Handbook on the Law of International Organizations, Edward Elgar Publishing Limited, 2011, pg. 91.

${ }^{168}$ Bengt Broms, The Doctrine of Equality of States as Applied in International Organizations, Vammala Kirjapaino, 1959, pg. 18.

${ }^{169}$ Hans Kelsen, The Principle of Sovereign Equality of States as a Basis for International Organization, 53 Yale L. J. 207 (1943-1944), pg. 207.

${ }^{170}$ Henry G. Schermes, Niels M. Blokker, International Institutional Law: Unity Within Diversity, Hotei Publishing, 2004; pg. 9 
equality of states. For one, it makes a reference to "sovereignty" in addition to equality. Broms notes the difference between sovereignty and equality by stating that:

"although sovereignty may also concern external relations, it is primarily connected with the internal aspects of States, whereas equality as applied to States is concerned only with the relations between them". ${ }^{171}$

However, sovereignty as corollary to the independence of states with regard to the principle of equality of states in IGOs at times may be misleading. One such false assumption is to relate equality (and not sovereignty) to the unanimity requirement in decision-making processes of IGOs. For example, there are authors such as Steinberg and Efraim that consider majority decision-making as a deviation from the principle of equality of states while unanimity (and consensus) decision-making to be in line with the principle of equality of states. ${ }^{172}$ This assumption is based on the understanding that sovereign equality means that no state cannot be bound without it consent and that no obligations can be imposed on a state without its will. ${ }^{173}$ As will be discussed in the next chapter ${ }^{174}$, any decision-making process is in line with the principle of equality of states if there is equality in representation and voting power. The unanimity requirement is more linked to sovereignty that to equality. Kooijmans makes this distinction by correctly stating that the unanimity requirement is not a consequence of the equality but of sovereignty and therefore majority decision-making is in line with equality. ${ }^{175}$ Such a distinction was also made by Anand when stating that "the adoption of the majority principle in the United Nations looks like the rejection of the principle of sovereignty" (not equality). ${ }^{176}$ In similar lines, Dunoff notes that "sovereign equality" has come under attack as a result of the fact that "sovereignty has come under sustained attack". He states:

"The intervening years have not been particularly kind to the concept of 'sovereign equality'. In part, this is because the concept of sovereignty has come under sustained attack. Concerns over transnational terrorism, internal conflict in failed states, and grave violations of human rights ranging from ethnic cleansing to war crimes to genocide have combined to persuade many that sovereigntybased and state-centric understandings of international law and international

\footnotetext{
${ }^{171}$ Bengt Broms, The Doctrine of Equality of States as Applied in International Organizations, Vammala Kirjapaino, 1959, pg. 75-76.

172 Athena Debbie Efraim, Sovereign (In)equality in International Organizations, Martinus Nijhoff, 2000, pg. 95, 116, 118, 119, 366. Also see Richard H. Steinberg, In the Shadow of Law or Power? Consensus-Based Bargaining and Outcomes in the GATT/WTO, 56 Intl. Org. 339 (2002), pg. 339.

${ }^{173}$ Hans Kelsen, The Principle of Sovereign Equality of States as a Basis for International Organization, 53 Yale L. J. 207 (1943-1944), pg. 213.

${ }^{174}$ On the application of the principle of equality of states to the different decision-making processes in IGOs, see Chapter III, below, pg. 95-101.

${ }^{175}$ Peter H. Kooijmans, The Doctrine of Legal Equality of States: An Inquiry Into the Foundations of International Law, A. W. Sythoff, 1964, pg. 238-239.

${ }^{176}$ See Anand, R.P. (2008-11-10). Sovereign Equality of States in International Law (Kindle Locations 361362). Hope India Publications. Kindle Edition.
} 
relations are outdated, and should be replaced with understandings grounded in a respect for human rights... Hence, norms protecting the sovereign equality of failed or rogue states, such as rules of nonintervention, increasingly appear out of date, and an international legal order premised on them increasingly illegitimate. "177

Having in mind that it is not always easy to make the distinction whether the discussion is about 'sovereignty' or 'equality' caution should be exercised in the review of the principle of equality of states in IGOs. The review of the principle of equality of states should focus on the concept of equality of states and not sovereignty. ${ }^{178}$ Sovereignty has always been a dynamic concept whose meaning has been constantly changing. From the perspective of the principle of equality of states, erosion of sovereignty does not necessarily result in erosion of equality of states if such erosion of sovereignty is equally applicable to all states. This is not so obvious at all times.

\section{VIII.CRITICISM TO THE PRINCIPLE OF EQUALITY OF STATES IN INTERNATIONAL LAW AND INTERNATIONAL ORGANIZATIONS}

Regardless of its strong presence in international law, many authors have criticized the principle of equality of states as an abstract rule with no practical application. While there are many specific arguments against the principle of equality of states, these arguments may be categorized in the following two groupings: the power argument stating that the principle does not reflect the power difference between states, and second, the inefficiency argument stating that the principle of equality of states makes decision-making processes inefficient. ${ }^{179}$ These criticisms as well as the arguments against them require further attention and will be addressed in this section.

The power argument is most frequently used by critics of the principle of equality of states and sometimes also by the supporters who try to spin the argument the other way around. Accordingly, to critics, equality is a fiction of diplomacy used for politeness towards the small states because:

\footnotetext{
177 Jeffrey L. Dunoff, Is Sovereign Equality Obsolete? Understanding Twenty-First Century International Organizations, 43 Neth. YBIL 99 (2013), pg.124.

${ }^{178}$ On a discussion regarding the concept of "sovereign equality" focused primarily on sovereignty see Brad R. Roth, Sovereign Equality and Moral Disagreement: Premises of a Pluralist International Legal Order, Oxford University Press, 2011. Roth argues that regardless of the fact that sovereign equality has been increasingly compromised, regardless of some modification and erosion, the principle has significant implications for relations between (liberal and non-liberal) states and that no systematic replacement has emerged. Moreover, the "principle embodies a vision of global order that - appropriately modified - remains both morally and prudentially defensible”. See Brad R. Roth, Sovereign Equality and Moral Disagreement: Premises of a Pluralist International Legal Order, Oxford University Press, 2011, pg. 25-28.

${ }^{179}$ Other criticism on the principle of equality of states is based on the premise that the principle of equality in international law means absolute equality in rights and duties. According to Kelsen the term "equality” does not mean that all States have the same duties and rights because they differ by the international treaties that create differences between States. See Hans Kelsen, The Principle of Sovereign Equality of States as a Basis for International Organization, 53 Yale L. J. 207 (1943-1944), pg. 208-209.
} 
"when serious issues come and the sky darkens and lands rise up at the sound of war and great issues are afoot, diplomatic fictions vanish at the thunder of the guns and the great powers dominate, govern and decide."

In similar terms, as early as 1915, Brown stated that:

"A great difficulty in the way of the formation of an international organization of states would probably be the insistence of smaller states on the recognition of the right of equality. It would, however, seem not only impossible, but grotesque to conceive of a world organization in which England and Liberia would be treated as having an equal status. ${ }^{181}$

It is legitimate to pose the question: how there can be a principle of equality of states when states are so different when it comes to their size, power, and population? Can superpowers be equals to microstates? Some states are considered to be great powers while others are considered medium or small powers in international relations theory. Some states are powerful and some are weak. For example, Liechtenstein and San Marino apparently were not admitted in 1920s to the League of Nations due to their size and became UN Member States only in $1990{ }^{182}$ As will be discussed in Chapter III, the differences between states with regard to parameters such as population size, GDP and territory are very significant. ${ }^{183}$ These estimates show that a majority of 173 UN Members having 173 votes or $89.63 \%$ of the total votes (out of the 193 in total), represent "only" $29 \%$ of the world population, $19.1 \%$ of world GDP and $32.71 \%$ of the territory of states per sq. $\mathrm{km}$. The remaining $20 \mathrm{UN}$ Members having 20 votes or $10.36 \%$ of the total votes represent: $71 \%$ of the world population, $80.9 \%$ of world GDP and $67.29 \%$ of the territory of states per sq. $\mathrm{km}$.

As a result of these differences between states, it is rather understandable that there is inequality between states.

The argument in favor of the application of the principle and which opposes the power-based theory spins the idea the other way around. The fact that states are different makes the principle necessary. Moreover, power is not absolute and the community of states is not a static one. On the contrary, it is rather dynamic and evolving. History teaches us that what was the great power of the past is not necessarily the great power of the present. Some states even vanished while others surfaced in the arena. Great Britain was the biggest superpower in the XIX century and had the largest colonial empire. It

\footnotetext{
${ }^{180}$ Talcott Williams, The Misleading Myth of the Equality of Nations, 96 Annals of the American Academy of Political and Social Science, The Place of the United States in a World Organization for Maintenance of Peace, 124 (1921), pg. 126.

${ }^{181}$ Philip Marshall Brown, The Theory of the Independence and Equality of States, 9 Amer. J. Int'l. L. 305 (1915), pg. 332.

${ }^{182}$ See: Geoffrey McNicoll, Population Weights in the International Order, 25 Popul. Dev. Rev. 411 (1999), pg. 421.

${ }^{183}$ On the differences between states with regard to population size, GDP and territory, see Chapter III, below, pg. 101-114.
} 
goes without saying that this is not the case anymore. Therefore, the maintenance of the principle of equality is also useful from this perspective.

On the other hand, formal equality is by necessity static as it has to be regulated by legal norm that establishes a situation of equality ${ }^{184}$ This is best reflected in the principle of equality of states which is applicable regardless of power shifts between states. Furthermore, the legal principle of equality makes sense exactly because the subjects it governs are different. There is a principle of equality of states when it comes to the law governing state relations because states are different. Among others, the participation of states in such a heterogeneous international society is also based on the existence of the principle of equality of states. The role of the principle of equality is to strengthen the position of weak states and enhance a climate of multilateralism. ${ }^{185}$

The second criticism to the principle of equality of states is based on the idea that this principle makes IGO decision-making more difficult and at times ineffective. In addition, the concept of equality of states at times may be abused, dysfunctional and unrealistic in decision-making in international organizations. ${ }^{186}$ There are even authors that consider that the principle of equality of states in international organizations should be abolished, as it makes decision-making less functional and does not meet criteria for legitimacy. ${ }^{187}$

Therefore, proportionality of rights and duties between states should exist in order to reflect inequalities between states (in particular in economic and technical institutions), because otherwise the incentive for powerful states to join IGOs might be questionable. ${ }^{188}$ As will be discussed in this book, in the existing development of the international community there are situations as in the UN Security Council where deviations from the principle of equality of states are a necessity. No UN Organ would take on the responsibility to efficiently deal with the maintenance of international peace and security in the world if all states (currently 193 UN Members) would participate equally and have equal voting power. Such a situation would decrease significantly (not to say paralyze) the efficiency and the effectiveness of the Security Council. However, unlike the necessary deviation from the principle of equality of states in the United Nations Security Council, more often the deviations from the principle of equality of states as discussed in this book are not the result of necessity to achieve efficiency and effectiveness of IGOs, but quite the contrary, they are the result of short cited power

${ }^{184}$ Ignaz Seidl-Hohenveldern, International Economic Law, Third Edition, Kluwer Law International, 1999, pg. 21.

${ }^{85}$ Juliane Kokott, States, Sovereign Equality, Max Planck Encyclopedia of Public International Law, para. 57-58. Available online at: http://www.mpepil.com, (visited March 2013).

${ }^{186}$ John H. Jackson, Sovereignty, the WTO and Changing Fundamentals of International Law, Cambridge University Press, 2006, pg. 58.

${ }^{187}$ Athena Debbie Efraim, Sovereign (In)equality in International Organizations, Martinus Nijhoff, 2000, pg. 359-383.

${ }^{188}$ Konstantinos D. Magliveras, 'Membership in international organizations' in Jan Klabbers and Åsa Wallendahl, Editors, Research Handbook on the Law of International Organizations, Edward Elgar Publishing Limited, 2011, pg. 91 
politics between states in their efforts to acquire better positions in their relations vis-àvis other states.

Finally, perhaps not as direct criticism, there are authors such as Dunoff who are of the opinion that in the future the principle of sovereign equality will be less central to understanding contemporary IGOs. ${ }^{189}$ However, according to Dunoff, it should be noted that this does not imply that there should be inequality between states. In these lines, he states:

"To ensure that I am not misunderstood, it is worth emphasizing that the claim that sovereign equality sheds little light on contemporary debates over IOs is emphatically not to claim that the concept of the legal equality of states is no longer meaningful or has lost relevance in all contexts, and should therefore be abandoned. Nor is it to claim that recent developments mean that the international community has or should seek to build an international legal order premised on sovereign inequality, whatever that term might mean". 190

To sum up, though criticized, the principle of equality of states is one of the cornerstones of international law and of the law of international organizations. Perhaps the best reply to critics of the principle of equality of states was given by Goebel in the now distant year of 1923 who considers the principle of equality of states necessary and inevitable. He stated:

"No one who has pursued the idea with some diligence and design through the vast body of political and legal literature can fail to be struck with the usefulness of marking with precision the growth and influence of the idea of equality in modern times. Not only from the point of view of historical development but also from that of analytical jurisprudence the principle of the equality of states stands forth as a useful and indispensable principle of international law. To those minds upon which the strict disciple of legal analysis produces the effect of confusion, there may be comfort in dismissing the principle as a "legal fiction." To the juristically minded, however, this term does not carry with it the implication of contempt that is doubtless intended by those who use it. Nor can the advocates of international government who champion the abandonment of the principle arouse much sympathy."191

\section{CONCLUSION}

The principle of equality of states is applicable to international organizations. The principle of equality of states in international organizations primarily applies to member

189 Jeffrey L. Dunoff, Is Sovereign Equality Obsolete? Understanding Twenty-First Century International Organizations, 43 Neth. YBIL 99 (2013), pg. 103.

190 Ibid., pg. 120-121.

${ }^{191}$ Goebel, Julius Jr., The Equality of States, 23 Colum. L. Rev. 247 (1923), pg. 277. 
states of international organizations, although there are instances when besides states also other entities such as international organizations have become members.

In international organizations, the principle of equality of states evolved through international conferences which adopted unanimity decision-making and the principle of one-state one-vote. Over time, the principle became part of the constitutions of international organizations. Before World War II, the principle of equality of states was present through the unanimity rule in the Covenant of the League of Nations and the equality of voting powers and representation in the Assembly. After World War II, the principle of equality of states became part of the UN Charter. Regionally, its wording is specifically part of the Charter of the Organization of American States, the OPEC, ASEAN. The Vienna Convention on the Representation of States in their Relations with International Organizations of a Universal Character refers to the principle of sovereign equality of states as a basic principle. Domestically, its application in international organizations represents a constitutional obligation for some states.

Unlike the debate on the meaning of the principle of equality of states in international law, the debate on the meaning of the principle of equality of states in international organizations is rather simple. For one, the focus is much more limited, and the rights and obligations are more obvious and measurable. The principle of equality of states in international organizations means equality of rights and duties of member states of international organizations. The principle of equality dictates same rights and duties without discrimination for all members. ${ }^{192}$ In discussing the meaning of the concept of sovereign equality as one of the emanations of the principle of equality of states a distinction should be made whether the focus of the discussion is sovereignty or equality of states. Having in mind that it is not always easy to make the distinction whether the discussion is about 'sovereignty' or 'equality' caution should be exercised in the review of the principle of equality of states in IGOs. The review of the principle of equality of states should focus on the concept of equality of states and not sovereignty. Sovereignty has always been a dynamic concept whose meaning has been constantly changing. From the perspective of the principle of equality of states, erosion of sovereignty does not necessarily result in erosion of equality of states if such erosion of sovereignty is equally applicable to all states. This is not so obvious at all times.

While it is clear that the principle of equality of states in IGOs requires equality in rights and obligations of states, the difficulty (as stated by Broms) in reviewing the application of the principle of equality of states in IGOs is to find out how much are states equal in their rights and duties in international organizations. Or, how much equality of states there is between states as a result of their equal capacity for rights. ${ }^{193}$

192 Konstantinos D. Magliveras, 'Membership in international organizations' in Jan Klabbers and Åsa Wallendahl, Editors, Research Handbook on the Law of International Organizations, Edward Elgar Publishing Limited, 2011, pg. 91.

193 Bengt Broms, The Doctrine of Equality of States as Applied in International Organizations, Vammala Kirjapaino, 1959, pg. 18. 
Therefore, the following Chapter will entirely focus on the relevant aspects for review in the application of the principle of equality of states in IGOs. 


\section{CHAPTER III \\ THE REVIEW OF THE PRINCIPLE OF EQUALITY OF STATES IN INTERNATIONAL ORGANIZATIONS}

\section{INTRODUCTION}

The most relevant question to this inquiry encompasses the following: what does a review of the principle of equality of states in international organizations entail? What should be under review in international organizations in order to address this question?

Interestingly enough, there is no overarching norm or a clear legal rule on the application of the principle of equality of states in international organizations. This is very intriguing, bearing in mind that much in international law and international relations refers to the principle of equality of states, and yet, it is not quite clear what this means de iure and de facto. Prominent authors of international law such as Shaw and Cassese consider the principle of equality of states an "umbrella" type of principle in international law, including within its scope the rights and obligations of states. On the other hand, authors such as Broms and Efraim dealing specifically with the principle of equality of states in international organizations have not approached this matter in an identical way. For example, Efraim primarily focuses on the review of the principle of equality of states in international organizations only with regard to the various decisionmaking processes in international organizations. Broms, on the other hand, has a more comprehensive approach and includes in his review three set of questions regarding the application of the principle of equality of states in international organizations. The first set of questions should address the fact of whether member states are grouped in various classes of members (with various rights and duties); second, whether member states are in the same position in regard to making decisions and recommendations; and third, whether decisions are binding on (non) member states when adopted without unanimity or when the voting powers of different member states varies. ${ }^{194}$

If examined, one may easily notice the broad range of application of the principle of equality of states in international organizations. Namely, when we speak of the application of the principle of equality of states we take into account that it is an umbrella principle covering not a single aspect (usually decision-making processes) but a number of aspects of international organizations (as Broms did). Therefore, in general

${ }^{194}$ See Bengt Broms, The Doctrine of Equality of States as Applied in International Organizations, Vammala Kirjapaino, 1959, pg. 19-20. 
terms this book takes a somewhat different approach then Efraim and Broms. As a preliminary issue it discusses the presence of the principle of equality of states in the founding treaty of the international organization under review. After discussing the presence of the principle of equality of states in the founding treaty, this book takes a more comprehensive approach by reviewing the principle of equality of states in international organizations in three sets of questions. These three sets of questions discuss: acquisition of membership (entering an IGO either as an original member through the negotiations process or through the admission/accession process); rights and obligations while being a member of an international organization (reflected in the representation of states, decision-making processes, equality of votes and financing); and suspension or termination of membership (being in the exit hallway with frozen membership through suspension, or exiting the international organization by expulsion or withdrawal).

To elaborate, the first set of questions discusses the process of acquisition of membership in international organizations. The coherence of the criteria for membership with the principle of equality of states, or the lack of it, can be best observed by reviewing whether the law of the IGO and its application in practice with regard to acquisition of membership results in equality or inequality between member states, i.e. the difference in their rights and duties. In this regard, it is important to review the negotiations for the establishment of the IGO and the possibility of acquiring original membership in the organization. After the organization is established it is important to review the admission or accession process.

The second set of questions discusses the right and obligations of member of IGOs after acquiring membership. With regard to members, i.e. the existing members, it is important to review whether there is equality between members in four distinct, yet related categories: representation, decision-making processes, voting power and financing.

The third set of questions discusses the decision-making processes when membership is limited as in cases of suspension or when membership comes to an end as in cases of termination of membership (either by expulsion or withdrawal). In these situations, it is also important to review the application of the principle of equality of states. This can be best reflected in the equality of rights of members in the decisionmaking processes regardless of whether they decide on, or they are the subject of cases, that result in suspension, withdrawal or the expulsion of members.

These questions have theoretical and practical importance and greatly affect the scope of the research by determining the extent of the application of the principle of equality to various aspects of membership in international organizations. This chapter provides for a general discussion of three sets of questions on the principle of equality of states in international organizations (acquisition of membership, decision-making, suspension and termination of membership) while the specific discussion relevant in particular for the United Nations, the World Trade Organization and the International 
Monetary Fund will be introduced in Chapter IV, Chapter V and Chapter VI, respectively.

\section{THE FOUNDING TREATIES OF INTERNATIONAL ORGANIZATIONS AND THE PRINCIPLE OF EQUALITY OF STATES}

The starting point in the review of the principle of equality of states in international organizations in all the aspects mentioned above, is to discuss the presence of the principle of equality of states in the founding treaty of the international organization under review. The founding treaty represents the most important legal source of any international organization, irrespective of whether if it is called the Covenant (as in the League of Nations), the Charter (in the United Nations), the Articles of Agreement (in the World Bank and the International Monetary Fund), the Convention (in the Multilateral Investment Guarantee Agency-MIGA), or the Treaty (as is the case with the European Union and its Lisbon Treaty). Whether the principle of equality of states is part of the law of international organizations can be observed by reviewing whether there are any direct or indirect references to the principle of equality of states in the founding treaty of the organization. As discussed in the previous section there are IGOs that have numerous direct references to the principle of equality of states in the constitutions of international organizations. This is important in order to determine the overall approach towards the principle of equality of states by a particular IGO. The position, meaning and importance of the principle of equality of states in the founding treaties of the UN, the WTO and the IMF will be discussed in more detail in the following chapters. ${ }^{195}$ However, even if the IGO does not have any direct references to the principle of equality of states in its founding treaty, it may yet be in compliance with the principle of equality of states in acquisition of membership, decision-making, and suspension or termination of membership.

\section{ACQUISITION OF MEMBERSHIP IN INTERNATIONAL ORGANIZATIONS AND THE PRINCIPLE OF EQUALITY OF STATES}

Having in mind that the notion "membership" in international organizations usually refers to the existing members, the common understanding is that the principle of equality of states is applicable to them only. This should be a logical approach as the application of the principle of equality should incorporate a review of the rights and obligations of members. However, it is difficult to reconcile such a position with the

\footnotetext{
${ }^{195}$ On the principle of equality of states in the UN Charter, see Chapter IV, below, pg. 123-127; in the WTO Agreement, see Chapter V, below, pg. 191-194; in the IMF Articles of Agreement see Chapter VI, below, pg. 247-250.
} 
fact that membership in international organizations and the principle of equality of states does not encompass only existing or current members, but also includes potential members as well. Therefore, of paramount importance is to review whether the criteria for acquisition of membership are in coherence with the principle of equality of states. This should be done for a simple, yet, crucial reason: acquisition of membership may determine the rights and duties of members and create situations of (in)equality.

With regard to the process of acquisition of membership in an international organization, a potential member can do so either as an original member by negotiating the establishment of the organization to be or, after the organization is established, it can do so through the admission or accession process. Participation in the preparatory work, even if it does not grant original membership rights, provides for a valuable opportunity to influence decisions and offers psychological advantages in comparison with the members that join the organization after it is established. On the other hand, the accession or admission process may entail additional obligations for future members. Both processes have ramifications for the application of the principle of equality of states in international organizations and require further attention. This section provides for a general discussion on the meaning and importance of acquisition of membership in international organizations in light of the principle of equality of states through either: 1. participation in the preparatory work for the establishment of an IGO, or, 2. through the admission/accession process. A more detailed discussion on the principle of equality of states in acquisition of membership in the UN, the WTO and the IMF will be presented in the following chapters. ${ }^{196}$

\section{THE NEGOTIATIONS FOR THE ESTABLISHMENT OF INTERNATIONAL ORGANIZATIONS AND ORIGINAL MEMBERSHIP}

The time before the establishment of an international organization is usually the time of negotiations and deliberations by the states that find common ground for the need and functions of the international organization. Blokker symbolically refers to terms such as unborn fetus, pregnancy which may last from months as was the case of the UN, years as was the case of the International Criminal Court (ICC), up to abortus provocatus in cases where for various reasons the initiative was made to fail such as the case with the European Defense Community (EDC). ${ }^{197}$ Whether states have the opportunity to participate in the preparatory meetings for the establishment of an international organization and thus acquire original member status has both a legal and a political impact on their rights and duties as members of the international organization, and thus on the applica-

\footnotetext{
${ }^{196}$ On the application of the principle of equality of states in the acquisition of membership in the UN, see Chapter IV, below, pg. 127-153; in the WTO, see Chapter V, below, pg. 194-220; in the IMF, see Chapter VI, below, pg. 250-266.

${ }^{197}$ Niels Blokker, International Organizations and Their Members, 1 Int'l. Org. L. Rev. 139 (2004), pg. 143. Also see, Gerry Simpson, The Great Powers, Sovereign Equality and the Making of the United Nations Charter, 21 Aust. YBIL 133 (2000), pg. 142, referring to the time period of preparation for establishing the UN as a "period of gestation".
} 
tion of the principle of equality of states. To name one important and obvious difference, the states participating in the establishment of the organization have the opportunity to become original members and therefore are not required to go through the admission or accession process. ${ }^{198}$ A number of international organizations make a distinction between original and non original members, for example, the League of Nations, the United Nations, the WTO, the IMF, and the FAO. ${ }^{199}$ Original members are also called the "a priori members"200 and they seem to be the most important key players for the creation and the establishment of an international organization. Without the original members the international organization to be would never have been established. Furthermore, original members can have special rights in comparison to the non original members. Such is the case with OPEC, which places the original members (the so called "Founder Members") in a more privileged position. A double majority of $3 / 4 \mathrm{of}$ the members but also the concurrent vote of all Founder Members is required for an admission of a new member to take place in OPEC. ${ }^{201}$ Another difference is that even without any specific formal rights for original members; such a status can provide substantial political gains. A great potential benefit for the states participating in the preparatory work is the opportunity to influence the founding treaty and consequently the institutional and substantive aspects of the organization to be. Their work may entail also additional gains as the Vienna Convention on the Law of Treaties considers the "preparatory work of the treaty and the circumstances of its conclusion" a supplementary means of interpretation to confirm the meaning of a treaty. ${ }^{202}$ Perhaps the last difference to be noted is that original members decide if other applicants will become members of an international organization through the admission or accession process. After the IGO is established based on the founding treaty negotiated in the preparatory work, the opportunities for amending the treaty and reform are usually very limited. Any empirical review of the matter would show that IGOs do not change much after being established. The potential members are usually expected to accept the main legal and institutional framework of the IGO negotiated and established in the preparatory work by the member participating in the negotiations (usually acquiring the status of original members). The potential members usually have only the option to join an international organization or to refuse to do so. This situation places the states having

\footnotetext{
198 Though having the potential to become original members (if such a category exists), the states that negotiate the establishment of the international organizations are not formally its members. In fact states may participate very actively in the negotiations on the establishment of an IGO and subsequently not become members of the IGO in question. For example, the tremendous impact in the preparatory work for the establishment of the League of Nations by President Wilson did not influence the United States sufficiently to join the organization initiated by its President.

${ }^{199}$ See Covenant of the League of Nations, Article 1; United Nations Charter Article 3; The Marrakesh Agreement Establishing the World Trade Organization, Article 11; Articles of Agreement of the International Monetary Fund, Article 2, section 1 and 2; Constitution of FAO Article 2.1.

${ }^{200}$ Niels Blokker, International Organizations and Their Members, 1 Int’l. Org. L. Rev. 139 (2004), pg. 140.

${ }^{201}$ See OPEC Statute, Article 7 C.

${ }^{202}$ See Vienna Convention on the Law of Treaties of Treaties, 1969, Article 32.
} 
access to the preparatory work for establishing an international organization in a better position in comparison to the states that do not have such an opportunity.

Last but not least, it is also important to discuss the negotiations for the establishment of IGOs in order to see the role of the principle of equality from at least two viewpoints. First, the negotiations offer a perspective on the position and the role of the principle of equality of states in the IGO to be established, and second, they also provide information on the positions of states toward the principle in the deliberations. ${ }^{203}$

With regard to the application of the principle of equality of states in the negotiations for the establishment of an IGO, it is relevant to inquire whether all states have the opportunity to participate in the negotiations. The participation of any state willing to do so in the preparatory work for the establishment of a universal international organization is in compliance with the principle of equality of states. Of course, this does not entail situations when a state decides not to participate in the establishment of an IGO. Quite the contrary, this entails situations when some (equal) states prevent others from participating. In such cases, from the perspective of the principle of equality of states it is difficult to argue that some states are more entitled than others to negotiate and establish an IGO. This would especially be more difficult to argue in establishing universal IGOs that by their own legal rules are obliged to strive for universality and encompass all states. The same line of reasoning is applicable in the establishment of a regional international organization. For example, in the establishment of the Organization of American States one should presume that all American States are equally entitled to participate. However, one should not jump to early conclusions by making this a rule of general application. It should be examined case by case or for each organization separately. The difficulty in this is that, as in every other rule, there are exceptions and difficulties in determining which states are entitled to such participation in regional IGOs and later to admission or accession. Things get unclear when establishing international organizations that do not have clear geographical or regional framework such as the case with the European Union lacking a concise definition of what is understood by a European State. Another example would be NATO and the ideological implications its membership entails. However, this is not clearly the case with universal organizations (such as the ones discussed in this book) which from their foundation aim at universal membership of all states regardless of size, ideology, geography or any other difference.

To sum up, a discussion on the principle of equality of states in the negotiations for the establishment of IGOs are also important due to the fact that they provide information on the role and the position of the principle of equality of states in the IGO to be established, as well as the position of states toward the principle in the process.

\footnotetext{
${ }^{203}$ For example, the Secretary of State, Cordell Hull, who was a member of the US delegation to the UN and acted as advisor to the US President, in a Congressional address called "equality the corner stone of the future international organization upon which the future international organization will be constructed, see Gerry Simpson, The Great Powers, Sovereign Equality and the Making of the United Nations Charter, 21 Aust. YBIL 133 (2000), pg. 143. footnote 60.
} 


\section{ACCESSION OR ADMISSION TO MEMBERSHIP}

After the international organization is established, regardless of whether an organization makes a distinction between original and non-original members, a state can no longer acquire membership through participating in the negotiations on the establishment of the international organization. Therefore, except for "original" members, there are also "admitted" members. ${ }^{204}$ The process of joining an international organization after the IGO has been established is given different names in international organizations. The usual denominations of the process of joining international organizations in the constitutions of different international organizations include the terms "admission" and "accession". For example, the term "accession" is used by the World Trade Organization while the term "admission" is used by the United Nations. ${ }^{205}$ The European Union as well speaks of "admission" in Article 49, paragraph 2 of the Lisbon Treaty. According to the Vienna Convention on the Law of Treaties the term "accession" mentioned next to the terms "ratification", "acceptance", and "approval" refers to the consent by a state to be bound by a treaty. ${ }^{206}$ This means that the act of accession represents the will of a state to be bound by that treaty. This consent is expressed by accession if the treaty provides such an opportunity for accession, if the negotiating states agreed that such consent may be expressed or if all the parties have subsequently agreed on this.

Having in mind the fact that the process of joining an international organization is formalized through acceding to the constituent treaty of the international organization, it seems that the term "accession" is more suitable than the term "admission" for two reasons. ${ }^{207}$ First, it is the term used by the Vienna Convention on the Law of Treaties. Second, it represents the process of a potential member joining the founding treaty and at the same time the international organization. On the other hand, the term "admission" seems to be more focused on the process from the perspective of the international organization that does (not) admit a member to join. By logic, accession refers to the consent of the new member state to the treaty while admission refers to the decisionmaking process of the members if the new member can accede to the treaty. The Covenant of the League of Nations seems to make this distinction. Namely, in Article 1, paragraph 1 it refers to accession when speaking of states acceding to the Covenant and it refers to admission in paragraph 2 when speaking of admission of new members if agreed by a two-thirds majority of the Assembly, thus transferring the focus from the

\footnotetext{
204 Philippe Sands and Pierre Klein, Bowett's Law of International Institutions, Sixth Edition, Sweet \& Maxwell, 2009, pg. 538. Admitted is a notion envisaged in the OPEC Statute, Article 7, D.

${ }^{205}$ See UN Charter, Article 3; WTO Agreement, Article XII.

${ }^{206}$ Vienna Convention on the Law of Treaties of 1969, Article 2. According to Article 5, the Vienna Convention "applies to any treaty which is the constituent instrument of an international organization and to any treaty adopted within an international organization”.

${ }^{207}$ In this text these terms will be used based on the specifications given in the relevant legal sources of the international organization. Otherwise, in order not to cause any confusion, both terms may be used as such interchangeably with the understanding that they have the same meaning.
} 
state joining the organization to the approval by the existing members of the organization. ${ }^{208}$

Regardless of the name, accession conditions may influence the position or the rights and duties of the prospective member in the future and affect the application of the principle of equality of states. As seldom is the case, accession or admission process to an international organization determines when a state can join an international organization, and in the process it may also determine the rights and duties of the member to be. In regard to the application of the principle of equality of states in accession to international organizations, a matter of paramount importance is whether the accession process is in compliance with the principle of equality of states and whether it creates different rights and obligations between members.

In order to address this issue, the following aspects should be reviewed: first, whether the accession criteria envisaged by the organization are consistent with the principle of equality of states or if they make a distinction between different categories of states; second, whether the criteria are equally applied in good faith in accessions; and third, whether member states are equal in decision-making regarding the accession of applicant states.

In regard to the first aspect, the accession criteria are in coherence with the principle of equality of states if they do not differentiate between states. It is not only the formal criteria that may differentiate between states but also, perhaps more importantly, the application of these criteria in practice. In fact, the difficulty with the application of the principle of equality of states is more dependent on the interpretation of the criteria for admission in good faith ${ }^{209}$ and according to the object and purpose of the founding treaty rather than the established criteria which, if applied, as such are not deviations from the principle of equality of states. The Vienna Convention on the Law of Treaties requires a treaty (including its provisions on accession/admission) to be interpreted in good faith and in light of its object and purpose. ${ }^{210}$ This brings us to the next aspect for review.

The second aspect to be reviewed is whether the criteria are applied in good faith equally to all cases of accession in the same manner, resulting in equality rather than in inequality of states. Even if the criteria for accession are in coherence with the principle of equality of states, the application in practice can result in different treatment between the various applicants and thus result in inequality. Here it is important to see whether the same rules in law are applied differently to different applicant states creating situations of inequality between states. Or to put it differently, whether there is equal treatment of all applicants or unequal treatment of, and thus discrimination between, states. Having said this, it does not come as a surprise that it has been observed that the:

${ }^{208}$ See Covenant of the League of Nations, Article 1.

${ }^{209}$ Article 2 (2) of the Charter creates an obligation for all members to fulfill in good faith their obligations by stating that: "All members, in order to ensure to all of them the rights and benefits resulting from membership, shall fulfil in good faith the obligations assumed by them in accordance with the present Charter".

${ }^{210}$ Vienna Convention on the Law of Treaties of 1969, Article 31. 
"interplay between law, politics and ideology appears to be more in evidence in admission to international organizations than in any other area of international law". 211

The third aspect to address is whether all member states are equal in decision-making regarding accession. Here it is important to review whether member states have an equal say in the accession of new applicants. There are different admission processes in international organizations. Magliveras categorizes them in the following three categories: first, straightforward admissions decided by a one organ (International Organization for Migration, World Tourism Organization); second, a more complex process which involves two or more organs (UN, UNIDO); and the third category, where the admission includes not only the consent of one or more organs but also the member to be is required to conclude a treaty of accession (WTO, EU, IMF, EFTA). ${ }^{212}$ The fact that member states have different representation and voting power in the various organs regarding accession decision-making processes creates inequality between states and represents a deviation from the principle of equality of states. These specific aspects of acquisition of membership will be addressed in the chapters on the UN, the WTO, and the IMF in regard to acquisition of membership in these international organizations.

\section{THE PRINCIPLE OF EQUALITY OF STATES IN THE DECISION-MAKING OF INTERNATIONAL ORGANIZATIONS}

Having discussed the application of the principle of equality of states in the acquisition of membership in international organizations, it is important to review the application of the principle after membership is acquired. In regard to the application of the principle of equality of states to members of international organizations, it is important to review whether there are differences between members in their rights and obligations in the decision-making of international organizations. The review of the principle of equality of states in the decision-making of international organizations will cover the equality of states in: 1.representation, 2.decision-making processes, 3. voting power and 4. financing. This section will provide a general discussion on the meaning and importance of decision-making in light of the principle of equality of states in international organizations. The financing of international organizations, due to its specific nature, will be dealt separately. A more detailed discussion on the application of the principle of

\footnotetext{
${ }^{211}$ Ebere Osieke, Admission to Membership in International Organizations: The Case of Namibia, 51 Brit. Y. B. Int'l. L. 189 (1980), pg. 189.

${ }^{212}$ Konstantinos D. Magliveras, 'Membership in international organizations' in Jan Klabbers and Åsa Wallendahl, Editors, Research Handbook on the Law of International Organizations, Edward Elgar Publishing Limited, 2011, pg. 90. In some IGOs such as the International Bureau of Weights and Measures or the International Whaling Commission a state can join only by giving a unilateral notification, see Henry G. Schermers \& Niels M. Blokker, International Institutional Law, Fifth Revised Edition, Martinus Nijhoff Publishers, 2011, pg. 80, footnote 92.
} 
equality in decision-making in the UN, the WTO and the IMF will be presented in the following chapters. ${ }^{213}$

\section{EQUALITY OF STATES IN REPRESENTATION}

Inherent to membership in any international organization is the right to representation, i.e. the representation of the member states in the organs of the organization. Without representation it does not matter what kind of decision-making processes an IGO is using. The state not being represented cannot participate at all in the decision-making. It can neither vote in a majority vote, nor block a decision in unanimity or consensus decision-making. This places such members in unequal positions compared to the members entitled to representation. Therefore, of paramount importance in this section is to first discuss the equality of states in representation.

Historically equal representation of member states has been an uneasy task for international organizations and their member states. In practice, it is easier to achieve this goal if the IGO has fewer members. This can be illustrated by comparing the failure to establish a Court of International Justice at the Hague Conference and the success of establishing the Central American Court of Justice. At the Hague Conference of 1907 the forty four participant nations failed to establish the already approved Court of International Justice due to demands for equal representation. ${ }^{214}$ These demands were based on the principle of equality of states which, if fully implemented by equal representation, would have resulted in the creation of a "judicial assembly" with 44 judges (one for each member state), rather than a "court”, which would ordinarily be composed of much fewer judges. ${ }^{215}$

On the other hand, in the case of the Central American Court of Justice (which was composed of five judges nominated by each of the five member states), the composition of the Court did not pose any difficulty in terms of equal representation.

In the application of the principle of equality of states with regard to representation in international organizations, it is important to review whether all members are, or have the potential equally to be, represented in all organs. In compliance with the principle of equality of states, all states should have equal representation or a potential for equal representation. In order to review whether representation of member states is in compliance with the principle of equality of states, a review of their representation in the organs of the IGO is required.

Historically, international organizations usually have a plenary organ, a nonplenary organ and a secretariat. This was the case with the League of Nations and this three part division of the main organs of the organization has often been copied by later

\footnotetext{
${ }^{213}$ On the application of the principle of equality of states in decision-making in the UN, see Chapter IV, below, pg. 153-177; in the WTO, see Chapter V, below, pg. 220-237; in the IMF, see Chapter VI, below, pg. 266-302.

${ }^{214}$ S. W. Armstrong, The Doctrine of the Equality of Nations in International Law and the Relation of the Doctrine to the Treaty of Versailles, 14 Am. J. Int’l. L. 540 (1920), pg. 540.

${ }^{215}$ Ibid., pg. 541.
} 
IGOs. In the plenary organs ${ }^{216}$ of the international organizations there is an application of the principle of equality of states if all members are equally represented. A greater difficulty in representation lies in non-plenary organs. Here, however, unlike the conventional wisdom, non-plenary organs do not per se represent a deviation from the principle of equality of states if members are equally entitled to representation in these non-plenary organs. A practice in line with the principle of equality of states in nonplenary organs would be the rotation of members where all members have equal access to representation. Authors also note that besides rotation, a non-plenary organ can also strive for equitable geographical distribution in order to enhance representation. ${ }^{217}$ However, unlike rotation, geographical representation does make a difference between the right of members to be represented and to represent themselves. Barbosa, the Brazilian delegate to the Hague Conference of 1907 during the discussions for the creation of the Court of Arbitral Justice made this point quite clear. He stated:

"let us distinguish, as should have been done at the outset, in order to solve the difficulty. There are two distinct rights: the right to nominate and the right to sit. In the right to nominate we will all be equal. But in the right to sit we will be absolutely unequal. Well then! It is this inequality which violates the equality of states. ${ }^{218}$

When it comes to representation it is important to review the representation in the various organs of an IGO separately but also in a complementary manner in order to order to understand the effects of representation on the principle of equality of states. There is a difference in the application of the principle of equality of states to an IGO if a plenary organ co-decides in matters together with a non-plenary organ in comparison to a situation when a non-plenary organ decides on its own. In this case the deviation from the principle of equality of states is of a more limited extent compared to situations where the non-plenary organ decides exclusively.

To sum up, for the application of the principle of equality of states with regard to representation in international organizations, it is important to review whether all members are equally represented or have equal potential for representation.

\footnotetext{
${ }^{216}$ A plenary organ may be named differently in the various organizations such as the case with the "General Assembly" of the UN, the "General Conference" of the ILO and UNESCO; the "Conference" in the FAO and the OAS; the "Congress" in the UPU, the "Assembly" in the WHO; the "Council" in the NATO and the OECD; and the "Board of Governors" in financial organizations such as IMF and World Bank (MIGA is an exception), see Henry G. Schermers \& Niels M. Blokker, International Institutional Law, Fifth Revised Edition, Martinus Nijhoff Publishers, 2011, pg. 297.

${ }^{217}$ Henry G. Schermers \& Niels M. Blokker, International Institutional Law, Fifth Revised Edition, Martinus Nijhoff Publishers, 2011, pg. 225.

${ }^{218}$ Edwin DeWitt Dickinson, The Equality of States in International Law, Harvard University Press, 1920, pg. 329.
} 


\section{EQUALITY OF STATES IN DECISION-MAKING PROCESSES: UNANIMITY, MAJORITY AND CONSENSUAL DECISION-MAKING}

Although the decision-making processes are central to many discussions on the principle of equality of states in IGOs, in fact, they are irrelevant for the application of the principle of equality of states as long as there is equality in representation and voting power. Such a conclusion is based on the discussion of the application of the principle of equality of states with regard to the unanimity, consensus or majority decisionmaking processes used by IGOs.

Decision-making is considered to be the most important activity of international organizations. ${ }^{219}$ Much of the decision-making processes in international organizations were borrowed from outside of international organizations as the:

"equalitarianism of traditional international law, the majoritanism of democratic philosophy, and the elitism of European great power diplomacy have been transferred to the sphere of international organization to serve as competing elements in shaping the approach to international decision-making". ${ }^{220}$

In this context, the "equalitarianism" of international law relates to the unanimity and equality of voting power, “majoritanism" to majority voting, while "elitism” relates to weighted voting. ${ }^{221}$ International organizations in their decision-making processes resort either to: unanimity ${ }^{222}$, consensus ${ }^{223}$, majority ${ }^{224}$ or a combination ${ }^{225}$ of these decision-

\footnotetext{
${ }^{219}$ Henry G. Schermers \& Niels M. Blokker, International Institutional Law, Fifth Revised Edition, Martinus Nijhoff Publishers, Leiden, Boston, 2011, pg. 705.

${ }^{220}$ Inis L. Claude, Swords into Plowshares: The Problems and Progress of International Organizations, Fourth Edition, Random House, 1971, pg. 118. Reference by Stephen Zamora, Voting in International Economic Organizations, 74 Am. J. Int'l. L. 566 (1980), pg. 571.

${ }^{221}$ Stephen Zamora, Voting in International Economic Organizations, 74 Am. J. Int'l. L. 566 (1980), pg. 571.

${ }^{222}$ As a general or exceptional rule unanimity is found in four global organizations such as: NATO, OECD, IMF, ILO and six regional organizations such as: the EU, the European Space Agency (ESA), the European Free Trade Association (EFTA), the Council of Europe, Benelux and OPEC. See Athena Debbie Efraim, Sovereign (In)equality in International Organizations, Martinus Nijhoff, 2000, pg. 116-117. Other authors also include the African Union and in some matters in the European Union and the Arab League, see Nigel D. White, 'Decision-making' in Jan Klabbers and Åsa Wallendahl, Editors, Research Handbook on the Law of International Organizations, Edward Elgar Publishing Limited, 2011, pg. 227. also see Jan Wouters and Philip De Mann, 'International organizations as law-makers' in Jan Klabbers and Åsa Wallendahl, Editors, Research Handbook on the Law of International Organizations, Edward Elgar Publishing Limited, 2011, pg. 195.

${ }^{223}$ Consensual decision-making has been enshrined as the primary decision-making method in the legal provisions of the Constitutions of the WTO, MERCOSUR, ASEAN, ROME Statute of the International Criminal Court, see Jan Wouters and Philip De Mann, 'International organizations as law-makers' in Jan Klabbers and Åsa Wallendahl, Editors, Research Handbook on the Law of International Organizations, Edward Elgar Publishing Limited, 2011, pg. 197.

${ }^{224}$ For example: the ILO, the IMF, the IBRD, the WIPO, the OAS. See Jan Wouters and Philip De Mann, 'International organizations as law-makers' in Jan Klabbers and Åsa Wallendahl, Editors, Research Handbook on the Law of International Organizations, Edward Elgar Publishing Limited, 2011, pg. 196; also see Nigel D. White, 'Decision-making' in Jan Klabbers and Åsa Wallendahl, Editors, Research Handbook on the Law of International Organizations, Edward Elgar Publishing Limited, 2011, pg. 225.

${ }^{225}$ For example unanimity and consensus in: the ASEAN, the CSCE (OSCE), the IMF executive committee, the GATT/WTO, the MERCOSUR, the NATO, the OECD, the UN Specialized Agencies (including, UNDP,
} 
making processes. Originally, it is considered that the primary decision-making mode of international organizations was unanimity. However, as time passed there was a shift to majority decision-making. From majority decision-making, IGOs in law or in practice further shifted to consensus decision-making, although a combination of them (majority and consensus decision-making) is also very much present in the different IGOs.

In the past, many authors considered that the principle of equality of states required nothing less than unanimity. This is based in the approach taken by the international conferences and to a certain extent to the League of Nations which also had unanimity as a primary (with exceptions) rule of decision-making. Unanimity decision-making also correlates to the notion of sovereign equality. The idea is that sovereign equality means that no state can be bound without its consent and that no obligations can be imposed on a state without its will. ${ }^{226}$ Unanimity decision-making is considered to be in line with the principle of equality of states as every member has equal power in adopting or blocking the adoption of any decision. However, states realized that unanimity may not be the best of the decision-making processes as it can substantially hamper efficiency. Even early on, Jean Jacques Rousseau considered unanimity an instrument for the minority to impose its will on the majority. ${ }^{227}$ In theory and practice, it is not even a minority but a single state that can block any decision. In order to address this difficulty of decision-making, after the Second World War the majority of international organizations shifted to majority decision-making. ${ }^{228}$ There are different types of majorities used by IGOs ranging from: simple majority (including more than half of the votes cast); qualified majority requiring a specific percentage of votes higher than the simple majority (two-thirds, three-quarters or three-fifths); relative majority (when there is a choice between two/three or more alternatives in majority decision making); absolute majority requiring a greater number of votes that can be achieved by any other solution; and double majority requiring a majority of votes and members. ${ }^{229}$ However, unlike unanimity decision-making, majority decision-making for some authors represents a deviation from the principle of equality of states. ${ }^{230}$ This proposition is based on the premise that the principle of equality of states does not allow for states to comply

executive committee of the UNHCR), see Richard H. Steinberg, In the Shadow of Law or Power? ConsensusBased Bargaining and Outcomes in the GATT/WTO, 56 Intl. Org. 339 (2002), pg. 339-340.

${ }^{226}$ Hans Kelsen, The Principle of Sovereign Equality of States as a Basis for International Organization, 53 Yale L. J. 207 (1943-1944), pg. 213.

${ }^{227}$ Roberto Herrera, Evolution of Equality of States in the Inter-American System, 61 Polit. Sci. Quart. 90 (1946), pg. 98-99.

${ }^{228}$ Unanimity is no longer applied even in conferences on the codification of international law, see Stephen Zamora, Voting in International Economic Organizations, 74 Am. J. Int'l. L. 566 (1980), pg. 574.

${ }^{229}$ See Henry G. Schermers \& Niels M. Blokker, International Institutional Law, Fifth Revised Edition, Martinus Nijhoff Publishers, 2011,pg. 561-568.

${ }^{230}$ Athena Debbie Efraim, Sovereign (In)equality in International Organizations, Martinus Nijhoff, 2000 , pg. 95, 116, 118, 119, 366. Also see Richard H. Steinberg, In the Shadow of Law or Power? Consensus-Based Bargaining and Outcomes in the GATT/WTO, 56 Intl. Org. 339 (2002), pg. 339. Similarly Anand states that "The adoption of the majority principle in the United Nations looks like the rejection of the principle of sovereignty" see Anand, R.P. (2008-11-10). Sovereign Equality of States in International Law (Kindle Locations 361-362). Hope India Publications. Kindle Edition. 
with decisions that they did not approve. ${ }^{231}$ To state it differently, the organization cannot enforce decisions on members that oppose the decision in hand. Therefore, organizations that are based on the principle of equality of states provide equal representation and voting power and decisions are adopted by consensus or unanimity. ${ }^{232}$ The assertion by Steinberg, Efraim and other authors that exclude majority decision-making as incompatible with the principle of equality of states is not based on the correct legal assumption. Namely, while stating that sovereign equality offers "equal representation and voting power" and requires unanimity and consensus decision-making, it wrongly excludes majority decision-making. Majority decision-making, when based on "equal representation and voting power" of all members is also in compliance with the principle of equality of states. When states consented to majority decision-making they also consented to accept decisions that they did not approve. Bearing in mind that all states have equal say in the decision-making process, and that they can equally be part of the "majority" or of the "minority" in the decision adopted, there is no deviation from the principle of equality of states. Kooijmans correctly states that the unanimity requirement is not a consequence of the equality but of sovereignty and therefore majority decisionmaking is in line with equality. ${ }^{233}$

In fact, any decision-making process is in line with the principle of equality of states as long as each state is equal to another in representation and voting power.

Regardless of the discussion on the (in)compatibility of majority-decision-making with the principle of equality of states, even majority decision-making proved to be a difficult mode in IGOs. Being outnumbered by the constant increase of new members as a result of decolonization, voting in international organizations presented a risk for western states. According to Jackson, the problem with majority decision-making structures, where every state in line with the principle of equality has one vote, is that the most powerful members will unlikely tolerate being obligated by a less powerful majority or by "the majority of mini-states." ${ }^{, 234}$ For example, in extreme (unlikely) cases members composing less than $5 \%$ of the world population can control majorities in international organizations such as the UN or the WTO. ${ }^{235}$ Therefore, even though empowered to majority decision-making, in practice, in the second half of the 20th century, a shift was made to consensual decision-making in the majority of international organizations. ${ }^{236}$ As a result, whether de jure or de facto, the most applicable decision-

\footnotetext{
${ }^{231}$ Athena Debbie Efraim, Sovereign (In)equality in International Organizations, Martinus Nijhoff, 2000, pg. 84.

${ }^{232}$ Richard H. Steinberg, In the Shadow of Law or Power? Consensus-Based Bargaining and Outcomes in the GATT/WTO, 56 Intl. Org. 339 (2002), pg. 339.

${ }^{23}$ Peter H. Kooijmans, The Doctrine of Legal Equality of States: An Inquiry Into the Foundations of International Law, A. W. Sythoff, 1964, pg. 238-239.

${ }^{234}$ John H. Jackson, Sovereignty, the WTO and Changing Fundamentals of International Law, Cambridge University Press, 2006, pg. 46-50.

235 Ibid., pg. 24.

${ }^{236}$ Jan Wouters and Philip De Mann, 'International organizations as law-makers’ in Jan Klabbers and Åsa Wallendahl, Editors, Research Handbook on the Law of International Organizations, Edward Elgar Publishing Limited, 2011, pg. 196-197.
} 
making mode of international organizations, consensus decision-making has attracted significant attention and a number of definitions were introduced both by international organizations and the legal doctrine.

In international organizations, it is interesting that the United Nations Juridical Yearbook twice tackled the notion of consensus and gave its explanation on the meaning of the notion once in 1974 and the second time in 1987. According to the first explanation of the use of consensus in the United Nations practices, it was stated that:

"In United Nations organs, the term "consensus" was used to describe a practice under which effort is made to achieve unanimous agreement; but if that could not be done, those dissenting from the general trend were prepared simply to make their position or reservation known and placed on the record." 237

The second explanation was a more comprehensive one. According to the 1987 United Nations Juridical Yearbook there is no established definition on consensus in the practice of the UN, however in practice it is understood to mean:

"adoption of a decision without formal objections and vote; this being possible only when no delegation formally objects to a consensus being recorded, though some delegations may have reservations to the substantive matter at issue or to part of it. The fact that consensus is recorded does not necessarily mean that there is unanimity." 238

Further on, according to the WTO Agreement, a decision is adopted by consensus if:

\footnotetext{
${ }^{237}$ United Nations Juridical Yearbook, 1974, Chapter VI, Selected legal opinions of the Secretariats of the United Nations and related inter-governmental organizations. Use of the Term Consensus in United Nations Practice, Summary of a statement made at the $311^{\text {th }}$ meeting of the Population Commission, on 6 March 1974. It was also explained that "no plenipotentiary conference under UN auspices had included in its rules of procedure a provision on consensus, partly due to the fact that it was somewhat difficult to arrive at an exact definition on consensus, and partly because the objective which usually sought, namely, that every effort should be made to achieve a consensus before a vote was taken, could better be achieved by simply an understanding at the beginning of the conference.” pg. 163-164.

${ }^{238}$ United Nations Juridical Yearbook, Chapter VI, Selected legal opinions of the Secretariats of the United Nations and related inter-governmental organizations. Meaning of consensus in the practice of the United Nations, Letter to the Legal Counsel, World Health Organization. 21 September 1987, pg 147-148. Except for the wording stated above, the UN Juridical Yearbook called for attention with regard to the following: a) consensus can be expressed in different ways, the weakest form is a decision adopted "without a vote" which may mean that while no objection to the decision was made certain delegations may also not be associated to closely to the issue in hand and second consensus may mean a decision adopted as the result of group effort to achieve a decision and the delegations are more closely associated with that decision and this is the general reflection of the usage of the term; b) legal status of decisions is not reflected by the decision-making process as they are considered binding once adopted as "the fact that it has been adopted by consensus or by means of a vote does not add to or diminish the legal value or significance of the decision in question" because if the decision is legally binding the way of adoption by consensus or voting does not make a decision more or less binding and c) if a delegation is not announcing that it does not participate in the decision and does not prevent the decision to be adopted by consensus it will viewed as the delegation was not present while if a delegation does not expressly state this fact than it is considered as participating in the decision-making. Though there is a practice in many UN organs to have consensus as a method for decision-making if this is not formally foreseen the delegations are entitled to ask for a vote if such a process is formally established.
} 
"no Member, present at the meeting when the decision is taken, formally objects to the proposed decision. ${ }^{239}$

According to Jackson, consensus is:

"often defined as legitimating a decision based on a proposal to which no member present has objected (so neither absences nor abstentions operate as consensus-blocking vote)."240

Having in mind the differences between the different decision-making processes, Schermers stated:

"consensus is strongly influenced by the legal rules on voting. When unanimity is required decisions can only be made by consensus. All members have the right of veto, and no concession needs to be made. When majority voting is possible, members may prefer to cooperate in reaching consensus on a proposal which they dislike, in order to avoid a majority decision on a proposal which they find still more objectionable. The risk of being out-voted may encourage stubborn members to compromise. Furthermore, concessions made in order to reach consensus can be more easily defended at home were the alternative is being outvoted. Consensus, therefore, can be more easily obtained in organizations which do not require unanimity. "241

Consensus decision-making provides for equal decision-making powers for all members and therefore is also in line with the principle of equality of states.

To sum up, all the decision-making processes, whether unanimity, consensus or majority are in line with the principle of equality of states, if there is equal representation and voting powers of member states. Another issue is how much legitimacy and effectiveness are transcended in decisions adopted by unanimity, consensus or majority.

In comparison to unanimity or consensus based decision-making where every state agrees or at least does not oppose a certain decision, the majority decision-making allows for the minority to be outvoted. ${ }^{242}$ Both consensus and unanimity give veto powers to any member though the pressure in consensus decision-making not to make use of this veto power seem higher for a number of reasons. Primarily this is as a result of not taking a vote in consensus decision-making and in such instances the use of the

\footnotetext{
${ }^{239}$ See WTO Agreement, Article IX, footnote 1.

${ }^{240}$ John H. Jackson, Sovereignty, the WTO and Changing Fundamentals of International Law, Cambridge University Press, 2006, pg. 50. In similar terms, Steinberg states that a decision based on consensus requires no manifestation of opposition by any member on the motion at issue. See Richard H. Steinberg, In the Shadow of Law or Power? Consensus-Based Bargaining and Outcomes in the GATT/WTO, 56 Intl. Org. 339 (2002), pg. 344.

${ }^{241}$ Nigel D. White, 'Decision-making' in Jan Klabbers and Åsa Wallendahl Editors, Research Handbook on the Law of International Organizations, Edward Elgar Publishing Limited, 2011, pg. 228.

242 Jaime Tijmes-LHL, Consensus and majority voting in the WTO, 8:3 World Trade Review 417 (2009), pg. 417 , footnote 3 .
} 
veto power actually requires a state to take a position (and not only to do so, but to cast a negative one). This creates political pressure for countries not to make use of their veto powers unless they have really strong reasons.

\section{VOTING POWERS AND EQUALITY OF STATES}

In close relation to decision-making processes is the issue of voting power. When it comes to voting power, it is a question of whether members have one vote or different voting strengths reflecting inequalities between members. ${ }^{243}$ There is compliance to the principle of equality of states with regard to voting powers as long as there is equal voting power between all states. This position is often formulated as the "one state, one vote" principle. The alternative to the principle is weighted voting. Weighted voting can be defined as a:

"system which assigns to members of international organizations votes proportioned on the basis of predetermined relevant criteria; it can mean something as simple as so many votes per so many millions of population, or something as complex as a mathematical formula based upon multiple factors which have been assigned varying weights (e.g., population, educational level, territory, trade, industrial development, national wealth, etc.). "244

Having in mind that the principle of equality of states requires equality of voting power, any inequality in voting power represents a clear deviation from the principle of equality of states. Authors agree that weighted voting represents a formal inequality and is not in compliance with the principle of equality of states. ${ }^{245}$

It should be noted that voting power has application only in majority voting and is irrelevant in unanimity or consensus decision-making. Namely, in cases where the formal or nominal decision-making process is based on unanimity or consensus, any form of weighted voting does not have any practical value in the process.

However, not all international organizations respect the one-vote one-state rule as some have introduced various weighted voting systems which result in inequality between members. Such clear evidence of inequality between members is found in the cases of the veto power of the permanent members of the UN Security Council as well as the weighted voting in the IMF, WB, and EBRD. ${ }^{246}$ The IMF and the World Bank are

\footnotetext{
${ }^{243}$ Henry G. Schermers \& Niels M. Blokker, International Institutional Law, Fifth Revised Edition, Martinus Nijhoff Publishers, 2011, pg. 24.

${ }^{244}$ Elizabeth McIntyre, Weighted Voting in International Organizations, 8 Int'l. Org. L. Rev. 484 (1954), pg. 484.

${ }^{245}$ Athena Debbie Efraim, Sovereign (In)equality in International Organizations, Martinus Nijhoff, 2000, pg. 23, 77, also see Gerry Simpson, The Great Powers, Sovereign Equality and the Making of the United Nations Charter, 21 Aust. YBIL 133 (2000), pg. 157.

246 Konstantinos D. Magliveras, 'Membership in international organizations' in Jan Klabbers and Åsa Wallendahl, Editors, Research Handbook on the Law of International Organizations, Edward Elgar Publishing Limited, 2011, pg. 91.
} 
the main organizations that use weighted voting. The use of weighted voting in these organizations may be justified by the need for such positions in the decision-making without which the donating states would not provide the necessary finances. ${ }^{247}$ However, in the IGOs that use weighted voting, the principle of sovereign equality "has all but disappeared". 248

An interesting model of weighted voting relevant for the principle of equality of states existed in the International Institute of Agriculture (IIA). Article 10 of the Convention of the International Institute of Agriculture of June 7, 1905 provides that:

"The nations adhering to the institute shall be classed in five groups, according to the place with each of them thinks it ought to occupy. The number of votes which each nation shall have and the number of units of assessment shall be established according to the following gradations: " 249

\begin{tabular}{ccc}
\hline GROUPS OF NATIONS & NUMBER OF VOTES & UNITES OF ASSESMENT \\
\hline I & 5 & 16 \\
II & 4 & 8 \\
III & 3 & 4 \\
IV & 2 & 2 \\
V & 1 & 1 \\
\hline
\end{tabular}

Similarly, the International Bureau of Industrial Property (IBIP) at Berne also had a proportion of units depending on the wish of the member joining the organization whether it wanted to be assigned to class 1 having 25 units, class 2 having 20 units, class 3 having 15 units, class 4 having 10 units, class 5 having 5 units, or class 6 having 3 units. ${ }^{250}$

Such a model providing for all states the opportunity to choose by their own desire the membership category to be assigned knowing beforehand the specific rights and obligations each category entails, has also implications for the principle of equality of states. This model from a formal legal perspective provides all states equal opportunity to choose any category. An opportunity provided equally for all states is in compliance with the principle of equality of states. In addition, this model may also have an additional comparative advantage if it would introduce a dynamic (not static) model by allowing states to shift from one category of membership into another depending on

${ }^{247}$ Nigel D. White, 'Decision-making' in Jan Klabbers and Åsa Wallendahl Editors, Research Handbook on the Law of International Organizations, Edward Elgar Publishing Limited, 2011, pg. 234.

${ }^{248}$ Ibid., pg. 225.

${ }^{249}$ Convention of the International Institute of Agriculture, June 7, 1905, Article 10.

${ }^{250}$ According to Dickinson, the same principle also applied among others to the International Telegraphic Union, the Universal Postal Union, the International, the International Office of Public Hygiene, see Edwin DeWitt Dickinson, The Equality of States in International Law, Harvard University Press, 1920, pg. 320-321; also see Elizabeth McIntyre, Weighted Voting in International Organizations, 8 Int'l. Org. L. Rev. 484 (1954), pg. 485-488. 
their development (economic, military or other). This is hardly possible in many IGOs that take a more static approach and require amendments of the founding treaties of IGOs in order for such membership shifts to occur (one such example are the permanent members of the Security Council).

However, the difficulty here is that states that have more resources have a better chance to choose categories that provide them with more rights and obligations in comparison to states that have more limited resources. As a result, the weighted voting system provided results in inequality of states in these international organizations with regard to equality of votes. However, such a model may prove very useful to ameliorate some of the inequalities in IGOs where the use of the weighted voting system does not even provide for an opportunity for states to choose by their own desire the category entailing specific rights and obligations in an IGO.

Regardless of the model of weighted voting used by IGO's, fortunately, the negative impact on the principle of equality of states to some extent is decreased as international financial organizations in practice usually use consensual decision-making. ${ }^{251}$ According to one study, the trend of international economic organizations is to move away from equal voting and recognize inequalities between states, and yet, at the same time, to move towards consensus based decision-making. ${ }^{252}$

It should be noted, however, that weighted voting, despite being criticized as a deviation from the principle of equality of states, it is also praised as a necessity.

In these lines, Amerasinghe noted that:

"weighted voting and apportioning budgetary contributions enabled the solution of some of the most difficult problems to which an underlying principle of equality of states could not find appropriate answers. "253

Aristotle considered as unjust if two unequal people receive equal shares and therefore each person should receive a proportionate share in "equal measure) ${ }^{254}$ Therefore the underlying idea is that the application of the principle of equality of states in international law should take into account the inequalities between states and based on them introduce valuation in standards inherent in international law. ${ }^{255}$ Furthermore there are authors that consider that differences in voting powers "explicitly and implicitly exist under the principle of formal equality and sovereignty”. ${ }^{256}$

\footnotetext{
${ }^{251}$ Athena Debbie Efraim, Sovereign (In)equality in International Organizations, Martinus Nijhoff, 2000, pg. 240

${ }^{252}$ Stephen Zamora, Voting in International Economic Organizations, 74 Am. J. Int'l. L. 566 (1980), pg. 588589.

${ }^{253}$ C. F. Amerasinghe, Principles of Institutional Law of International Organizations, Second Edition, Cambridge University Press, 2005, pg. 5.

${ }^{254}$ Peter H. Kooijmans, The Doctrine of Legal Equality of States: An Inquiry Into the Foundations of International Law, A. W. Sythoff, 1964, pg. 23.

255 Ibid., pg. 40.

${ }^{256}$ See Thomas Cottier, Satoko Takenoshita, 'Decision-Making and the Balance of Powers in WTO Negotiations: Towards Supplementary Weighted Voting', in Stefan Griller, Editor, At the Crossroads: The World Trading System and the Doha Round, Springer, 2008, pg. 194. The authors further state that "equality,
} 
With regard to weighted voting, one of the most important questions to address is whether there are clear and adequate criteria for the relative weights. ${ }^{257}$ According to Kooijmans, the assessment on giving special weighted voting rights should be based on law. ${ }^{258}$ The most frequently cited parameters as the basis for weighted voting usually encompass: population size, economic power or GDP and the size of territory. If the existing differences between states in these parameters are compared, any analysis will show great disparities between states. For this purpose, a distinction will be made between the 20 states that have the largest \% of the world population, GDP and territory and the remaining 173 out of the 193 UN Members. ${ }^{259}$

The first parameter considered is the population size per country. Population size is often considered the most important criterion having in mind possible future scenarios such as the creation of a global civil society and the de-factorizing role of states. ${ }^{260}$ As Kooijmans noted: "man is the centre of Creation and as such the centre of each legal system, therefore also of international law". ${ }^{261}$

According to UN data of 2010, the 20 most populous states of the world combined make up for 4.84 billion of the total world population of 6.89 billion. ${ }^{262}$

The following table provides specific information on the 20 most populous states of the world:

Table 1: The 20 most populous states of the world

\begin{tabular}{lll}
\hline Rank & Country & Population mil. \\
\hline 1 & China & 1.341 \\
2 & India & 1.225 \\
3 & United States & 310 \\
4 & Indonesia & 240 \\
5 & Brazil & 195
\end{tabular}

however, requires that differences are based upon relevant and rational factual distinctions. They need to be justified in light of the overall goal and purpose...support efficiency and contribute to its legitimacy”.

${ }^{257}$ Stephen Zamora, Voting in International Economic Organizations, 74 Am. J. Int'l. L. 566 (1980), pg. 592.

${ }^{258}$ Peter H. Kooijmans, The Doctrine of Legal Equality of States: An Inquiry Into the Foundations of International Law, A. W. Sythoff, 1964, pg. 240.

${ }^{259}$ The reason in distinguishing between 20 states and the rest is related to the existing example of the G20 Group which is considered to be the premier forum for international cooperation in global economic and financial issues. The European Union and the following states are represented in the G20 Group: Argentina, Australia, Brazil, Canada, China, France, Germany, India, Indonesia, Italy, Japan, the Republic of Korea, Mexico, Russia, Saudi Arabia, South Africa, Turkey, the United Kingdom, the United States of America. For more details see G20 web page at http://www.g20.org/, (visited May 2013).

${ }^{260}$ Geoffrey McNicoll, Population Weights in the International Order, 25 Popul. Dev. Rev. 411 (1999), pg. 412.

${ }^{261}$ Peter H. Kooijmans, The Doctrine of Legal Equality of States: An Inquiry Into the Foundations of International Law, A. W. Sythoff, 1964, pg. 37. For a discussion on the importance that Kooijmans attributed to man with regard to the principle of equality of states see Janne E. Nijman and Wouter G. Werner, Legal Equality and the International Rule of Law, 43 Neth. YBIL 3 (2013), pg. 8-9 and Jeffrey L. Dunoff, Is Sovereign Equality Obsolete? Understanding Twenty-First Century International Organizations, 43 Neth. YBIL 99 (2013), pg. 106.

${ }^{262}$ Estimates based on United Nations Population Division, Department of Economic and Social Affairs, World Population Prospects: The 2010 Revision, POP/DB/WPP/Rev.2010/02/F01, New York, 2011. 


$\begin{array}{lll}6 & \text { Pakistan } & 174 \\ 7 & \text { Nigeria } & 158 \\ 8 & \text { Bangladesh } & 149 \\ 9 & \text { Russia } & 143 \\ 10 & \text { Japan } & 127 \\ 11 & \text { Mexico } & 113 \\ 12 & \text { Philippines } & 93 \\ 13 & \text { Viet-Nam } & 88 \\ 14 & \text { Ethiopia } & 83 \\ 15 & \text { Germany } & 82 \\ 16 & \text { Egypt } & 81 \\ 17 & \text { Iran } & 74 \\ 18 & \text { Turkey } & 73 \\ 19 & \text { Thailand } & 69 \\ 20 & \text { Congo } & 66\end{array}$

TOTAL

4.84 billion

This means that the 20 most populous states of the world represent more than $2 / 3$ or around $71 \%$ of the world population while the remaining 173 UN states represent less than $1 / 3$ or around $29 \%$ of the world population. ${ }^{263}$

This division can be better illustrated in the following chart:

Chart 1: Share of world population between the 20 most populous states and the remaining 173 states

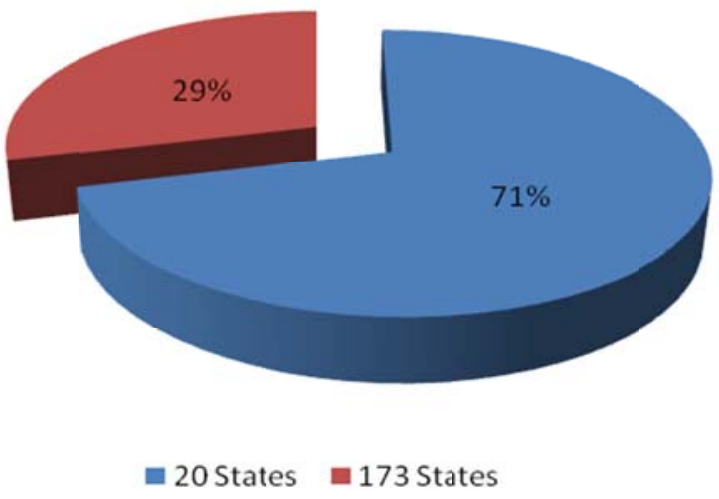

Analyzed from the perspective of a universal international organization applying majority decision-making in line with the principle of equality of states having onemember one-vote rule, it results that the overwhelming majority of 173 votes represent less than $29 \%$ of the world population, while the remaining 20 votes represent an

${ }^{263}$ Note that the difference in percentage would be even greater if taken into fact that not all of the world population is represented by its own state in the UN. 
overwhelming $71 \%$ of the world population. Except for the significant disparity between states in the size of their populations, there is also a strange paradox. Namely, the existence of the principle of equality of states (developed through the analogy of equality of men) requiring equality of voting power and representation results in significant inequality between men. To illustrate, the 1.35 billion Chinese, or the 310 million Americans under the principle of equality of states are entitled to equal representation and voting power as are the 20.000 inhabitants of Palau or the 10.000 inhabitants of Nauru. This is quite paradoxical result as obviously men are considered equal under municipal law and international law alike.

Perhaps there is some justification that in this case we are not addressing the rights of men as individuals but their collective rights as nations represented by states. Another justification would also be that it would not be an easy task for states to agree for a weighted voting system based on the size of their population. Note that around $60 \%$ of the world population lives in Asia and it would be difficult to convince the remaining states outside of Asia that in a universal IGO they would be entitled to 'only' around 40 $\%$ of representation and voting power.

Be it as it may, the discrepancy in the population size between states is so significant that it represents a considerable difficulty in the application of the principle of equality of states. Moreover, the result is also paradoxical as it creates inequality between men as individuals on the world scale. In a world community of men which may probably take place if and when states would seize to exist, "equality of men" and not the "equality of states" would be the principle to enforce (in a dimension beyond the scope of this book).

The second parameter considered is the GDP per country. The discrepancy in \% between the 20 most economically advanced countries and the rest of the world is even greater in comparison to population size. According to the Word Bank data for 2011, from the total of world GDP for 2011 of US\$ 70,020,432 m., 20 states combined comprise for US\$55,953,385 m. ${ }^{264}$ The following table provides specific information on the 20 states with the highest GDP in the world:

${ }^{264}$ See World Bank web site at: http://data.worldbank.org/data-catalog/GDP-ranking-table, (visited May 2013). 
Table 2: The 20 states of the world with the highest GDP

\begin{tabular}{|c|c|c|}
\hline Rank & $\begin{array}{l}\text { Economy (GDP) } \\
2011 \text { WB Data }\end{array}$ & Mill. \$ \\
\hline 1 & United States & $14,991,300$ \\
\hline 2 & China & $7,318,499$ \\
\hline 3 & Japan & $5,867,154$ \\
\hline 4 & Germany & $3,600,833$ \\
\hline 5 & France & 2,773,032 \\
\hline 6 & Brazil & $2,476,652$ \\
\hline 7 & United Kingdom & $2,445,408$ \\
\hline 8 & Italy & 2,193,971 \\
\hline 9 & India & $1,872,840$ \\
\hline 10 & Russian Federation & $1,857,770$ \\
\hline 11 & Canada & $1,736,051$ \\
\hline 12 & Spain & $1,476,882$ \\
\hline 13 & Australia & 1,379,382 \\
\hline 14 & Mexico & $1,153,343$ \\
\hline 15 & Korea, Rep. & $1,116,247$ \\
\hline 16 & Indonesia & 846,832 \\
\hline 17 & Netherlands & 836,074 \\
\hline 18 & Turkey & 774,983 \\
\hline 19 & Switzerland & 659,308 \\
\hline 20 & Saudi Arabia & 576,824 \\
\hline
\end{tabular}

These 20 states represent around 79.91\% of the world GDP while the remaining 173 states represent around $20.09 \%$ of the world GDP with US\$14,067,047 m.

This division can be better illustrated in the following chart: 
Chart 2: Share of world GDP between the 20 states representing the largest economies of the world and the remaining 173 states

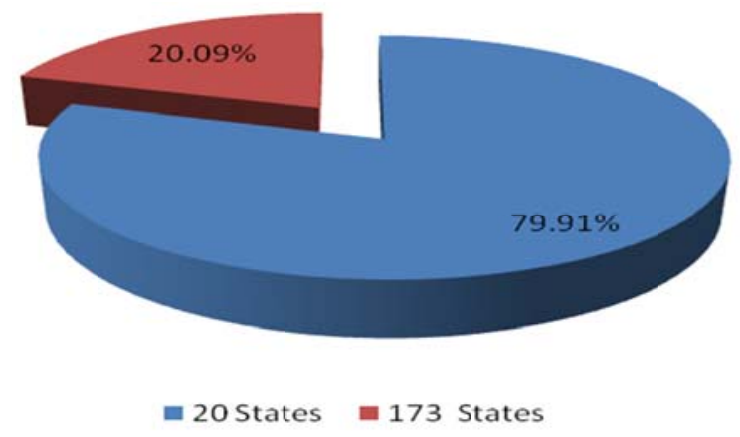

Analyzed from the perspective of a universal international organization applying majority decision-making in line with the principle of equality of states having onemember one-vote rule, it results that the overwhelming majority of 173 votes represent less than $20.09 \%$ of the world economy, while the remaining 20 votes represent an overwhelming $79.91 \%$ of the world economy.

The third parameter considered is the size of the territory per state. There is also quite significant difference between the 20 largest states by territory and the remaining 173 states. The following table ${ }^{265}$ provides specific information on the 20 largest states by territory in the world:

${ }^{265}$ See CIA Factbook web site at: https://www.cia.gov/library/publications/the-world-factbook/rankorder/2147rank.html?countryName=Australia\&countryCode=as\&regionCode=aus\&rank=6\#top, (visited October, 2012). 
Table 3: The 20 largest states of the world by territory

\begin{tabular}{|c|c|c|}
\hline Rank & Country & (sq km) \\
\hline 1 & Russia & $17,098,242$ \\
\hline 2 & Canada & $9,984,670$ \\
\hline 3 & United States & $9,826,675$ \\
\hline 4 & China & $9,596,961$ \\
\hline 5 & Brazil & $8,514,877$ \\
\hline 6 & Australia & $7,741,220$ \\
\hline 7 & India & $3,287,263$ \\
\hline 8 & Argentina & $2,780,400$ \\
\hline 9 & Kazakhstan & $2,724,900$ \\
\hline 10 & Algeria & $2,381,741$ \\
\hline 11 & Congo, Democratic Republic of the & $2,344,858$ \\
\hline 12 & Saudi Arabia & $2,149,690$ \\
\hline 13 & Mexico & $1,964,375$ \\
\hline 14 & Indonesia & $1,904,569$ \\
\hline 15 & Sudan & $1,861,484$ \\
\hline 16 & Libya & $1,759,540$ \\
\hline 17 & Iran & $1,648,195$ \\
\hline 18 & Mongolia & $1,564,116$ \\
\hline 19 & Peru & $1,285,216$ \\
\hline 20 & Chad & $1,284,000$ \\
\hline
\end{tabular}

These 20 largest states represent around $67.29 \%$ of the territory of states, while the overwhelming majority of 173 states represent around $32.71 \%$ of the territory.

This division can be better illustrated in the following chart: 
Chart 3: Size of territory between the 20 largest states and the remaining 173 states

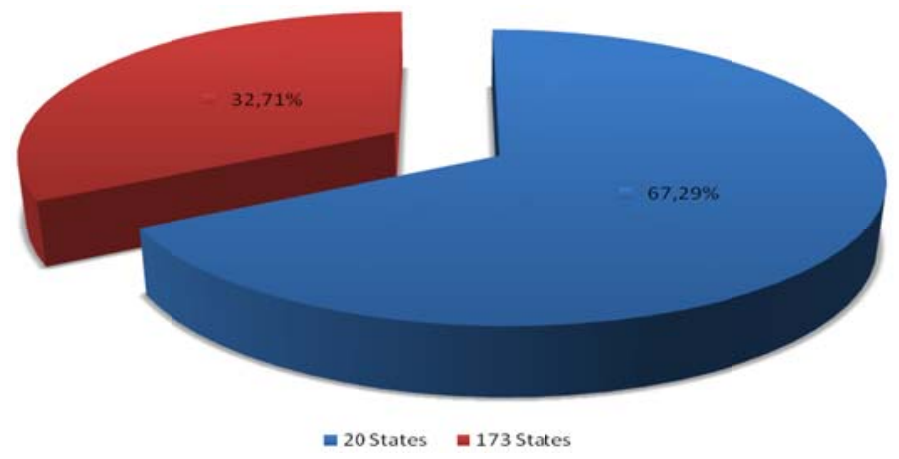

Analyzed from the perspective of a universal international organization applying majority decision-making in line with the principle of equality of states having onemember one-vote rule, it results that the majority of 173 votes represent only $32.71 \%$ of the world territory of states. The remaining 20 votes represent an overwhelming $67.29 \%$ of the territory of states.

If the data on the 20 states representing the largest share of the world GDP, population, and territory is merged the result would also be interesting. The following table provides specific information on the 20 states of the world representing the largest share of the world GDP, population and territory: 
Table 4: The 20 states representing the world largest share of GDP, population, and size of territory

\begin{tabular}{|c|c|c|c|}
\hline Rank & (GDP)Economy & Population size & Size of territory \\
\hline 1 & United States & China & Russia \\
\hline 2 & China & India & Canada \\
\hline 3 & Japan & United States & United States \\
\hline 4 & Germany & Indonesia & China \\
\hline 5 & France & Brazil & Brazil \\
\hline 6 & Brazil & Pakistan & Australia \\
\hline 7 & UK & Nigeria & India \\
\hline 8 & Italy & Bangladesh & Argentina \\
\hline 9 & India & Russia & Kazakhstan \\
\hline 10 & Russia & Japan & Algeria \\
\hline 11 & Canada & Mexico & Congo, \\
\hline 12 & Spain & Philippines & Saudi Arabia \\
\hline 13 & Australia & Viet Nam & Mexico \\
\hline 14 & Mexico & Ethiopia & Indonesia \\
\hline 15 & Korea, Rep. & Germany & Sudan \\
\hline 16 & Indonesia & Egypt & Libya \\
\hline 17 & Netherlands & Iran & Iran \\
\hline 18 & Turkey & Turkey & Mongolia \\
\hline 19 & Switzerland & Thailand & Peru \\
\hline 20 & Saudi Arabia & Congo & Chad \\
\hline SHARE \% & $79.91 \%$ & $71 \%$ & $67.29 \%$ \\
\hline
\end{tabular}

A striking feature is that out of these 20 states, only six belong to all three categories: United States, China, Brazil, Russia, India and Indonesia. Four states: Japan, Germany, Mexico and Turkey belong to the category of the 20 states with the largest population and GDP but not size. Two states: Canada and Australia belong to the category of the 20 largest states regarding GDP and size but not population. Eight states: France, UK, Italy, Spain, Korea, Netherlands, Switzerland and Saudi Arabia belong to the category of the 20 largest states regarding GDP but not population or size.

The great disparity between the 20 greatest states and the remaining 173 in any of these parameters represents a difficult reality that at times weakens efforts for the application of the principle of equality of states. However, it also shows that even between these 20 states there are no easy solutions that would offer some kind of a mathematical formula for a proportional weighted voting that would be considered fair as they also remain very much different. It is obvious that the state with the largest economy of the world is not the one with a largest population or size, the state with the largest population of the world is not the one with the largest economy or size, and the state with the largest size of the world is not the one with the largest economy or population. Another important aspect to the application of the principle of equality of states 
is that the remaining 173 states possess substantially smaller share of the world population, GDP and territory. It is not only that these 20 states are so "great", but also the fact that the remaining 173 are so "small" which poses a significant difficulty for the application of the principle of equality of states. As stated by Claude:

"Weakness, no less, than power, presents problems for the multistate system... is that this kind of state tends to become not a trouble-maker but a trouble spot."

\section{THE PRINCIPLE OF EQUALITY OF STATES IN FINANCING INTERNATIONAL ORGANIZATIONS}

Sentiments about equality in rights as corollary to the equality in obligations are also present among authors with regard to the application of the principle of equality of states. ${ }^{267}$ The doctrine of equality of states has too often focused on the rights of states without including the duties of states. ${ }^{268}$

For Dickinson, if applied to international organizations, the equal capacity for rights also requires equality in contribution. ${ }^{269}$ Having said this, it is of interest to see the application of the principle of equality of states when it comes to financing international organizations. In more specific terms, for the application of the principle of equality of states in financing it is important to discuss whether there is equality of financing obligations between members, whether there is equality with regard to the decision-making process determining financial obligations of members and whether there is a proportionality between rights and obligations, especially in cases when some members have special voting powers. An obvious reality is that when it comes to financing, economically more advanced states carry a greater financial responsibility. ${ }^{270}$ This has been the case from the time of the League of Nations requiring for the expenses needed for its functioning to be borne by the members "in the proportion decided by the Assembly" ${ }^{271}$ What is intriguing is that even supporters of the principle of equality of states in international organizations do not address in great detail the inequality of financing of international organizations between states. As Sohn stated:

\footnotetext{
${ }^{266}$ Inis L. Claude, Jr., Introduction: The Central Challenge to the United Nations: Weakening the Strong or Strengthening the Weak? 14 Harv. Int'l. L. J. 516 (1973), pg. 524.

${ }^{267}$ For example, according to Herrera, perfect equality is a utopia which to be achieved has to fulfill two tests: first, equal voice and, second, in order for every state to have equal rights it should also have equal duties, see Roberto Herrera, Evolution of Equality of States in the Inter-American System, 61 Polit. Sci. Quart. 90 (1946), pg. 118.

${ }^{268}$ Peter H. Kooijmans, The Doctrine of Legal Equality of States: An Inquiry Into the Foundations of International Law, A. W. Sythoff, 1964, pg. 40-41.

${ }^{269}$ Edwin DeWitt Dickinson, The Equality of States in International Law, Harvard University Press, a1920, pg. 335.

${ }^{270}$ The United States for example had much greater financial obligations, disproportionate to its voting power in the Inter-American system. See Roberto Herrera, Evolution of Equality of States in the Inter-American System, 61 Polit. Sci. Quart. 90 (1946), pg. 105.

${ }^{271}$ Covenant of the League of Nations, Article 6, para 5.
} 
"whenever the question of paying the expenses of an international organization is raised, the different champions of state equality show much less, if any, insistence on equality of contributions. The larger the expenses, the greater the insistence that they be graduated according to the size and economic power of the countries. Though the Latin American Republics are eager to fight for equality of state representation at international conferences of American Republics, they did not hesitate to adopt a scale based on population for paying the expenses of the Pan American Union; while everybody has an equal vote, the United States is paying more than half of the expenses of that Union." ${ }^{272}$

If any weighted voting system represents a deviation from the principle of equality of states in IGOs, so does such a weighted financing system where members have different financial obligations toward IGOs. These aspects of financing in the United Nations, the IMF and the WTO will be discussed in more detail in the following chapters. ${ }^{273}$

\section{THE PRINCIPLE OF EQUALITY OF STATES IN SUSPENSION, EXPULSION AND WITHDRAWAL OF MEMBERSHIP}

The principle of equality of states also applies in situations when membership is either limited (as in cases of suspension) or when it comes to an end (as in cases of termination of membership either by expulsion or withdrawal). This section provides for a general discussion on the meaning and importance of suspension and termination either in the form of expulsion or withdrawal in light of the application of the principle of equality of states in international organizations.

International organizations use suspension as a sanction for non-compliance by suspending membership rights which vary from loss of voting rights, attendance rights or rights to use services of the organization. ${ }^{274}$ In fact, suspension may be as much a sanction for non-compliance as an instrument to enforce compliance. In regard to the application of the principle of equality of states in cases of suspension, it is important to review whether all members are equal in the decision-making process. It is important to review among others whether the decision on suspension of a member is adopted by a plenary or a non-plenary organ, whether members have equal voting powers in the decision making process, whether all members are equally under the threat of suspension or actual suspension in the institutional framework of the IGO. If in an IGO there is a difference in the rights and obligations of members in the decision-making (represen-

\footnotetext{
${ }^{272}$ Louis B. Sohn, Weighting of Votes in an International Assembly, 38 Am. Pol. Sci. Rev. 1192 (1944), pg. 1192-1193.

${ }^{273}$ For a discussion on the financial contributions of members in light of the application of the principle of equality of states in the UN, see Chapter IV, below, pg. 177-180; in the WTO, see Chapter V, below, pg. 237239; in the IMF, see Chapter VI, below, pg. 302.

${ }^{274}$ Philippe Sands and Pierre Klein, Bowett's Law of International Institutions, Sixth Edition, Sweet \& Maxwell, 2009, pg. 545.
} 
tation, equality of voting powers) regarding the threat thereof or actual suspension of members when a member decides on the suspension of another member or is suspended, there is non-compliance with the principle of equality of states.

With regard to termination of membership, it should be noted that it can occur in any of the following modes: withdrawal, expulsion, or if the IGO or the member (state) ceases to exist. ${ }^{275}$ However, only the first two modes (withdrawal and expulsion) are relevant for the principle of equality of states and will be discussed in light of the application of the principle of equality of states in IGOs. The last two modes of termination of membership (if the IGO or the member ceases to exist) are not linked (at least not directly) to the principle of equality of states in international organizations and therefore will not be part of this discussion.

Unlike withdrawal from membership, expulsion is in contradiction to voluntary withdrawal because it is an enforcement measure enforced upon and taken against the will of the member state. ${ }^{276}$ Expulsion or the threat thereof can be a measure to enforce compliance with obligations. While the threat of expulsion may represent a measure for compliance, expulsion itself actually results in termination of membership. Jenks considers expulsion a crude device "quite incapable of achieving any lasting result in a community the units of which are states and one of the characteristics of which is therefore a very low rate of mortality". ${ }^{277}$ In regard to the application of the principle of equality of states in cases of expulsion, it is important to review whether all members are equal in the decision-making processes. Similarly to suspension, in expulsion from IGOs it is important to discuss whether the decision on the expulsion of a member is adopted by a plenary or a non-plenary organ, whether members have equal voting powers in the decision-making process, whether all members are equally under the threat thereof or actual expulsion of members in the institutional framework of the IGO. If in an IGO there is a difference in the rights and obligations of members in the decision-making (representation, equality of voting powers) regarding the threat thereof or actual expulsion of members, there is non-compliance with the principle of equality of states.

Withdrawal from membership represents a unilateral act of the free will of states to withdraw from an organization. Although it seems that withdrawal is not related to the principle of equality of states, this is not always true. In regard to the application of the principle of equality of states in cases of withdrawal, it is important to discuss if all members can equally withdraw from an IGO. In addition, it is also of interest to discuss whether any member can withdraw unilaterally or if a decision by the IGO in question is needed. If the IGO adopts a decision on withdrawal, it is important to see whether

\footnotetext{
${ }^{275}$ See Henry G. Schermers \& Niels M. Blokker, International Institutional Law, Fifth Revised Edition, Martinus Nijhoff Publishers, 2011, pg. 98.

${ }^{276}$ Hans Kelsen, The Law of the United Nations: A Critical Analysis of its Fundamental Problems, With Supplement, Stevens \& Sons Limited, 1951, pg. 710.

277 Alison Duxbury, The Participation of States in International Organizations, the Role of Human Rights and Democracy, Cambridge University Press, Cambridge, 2011, pg. 23.
} 
among others such a decision on withdrawal is adopted by a plenary or a non-plenary organ, whether members have equal voting powers in the decision-making process, and whether all members are equally in the position to withdraw from an IGO. If in an IGO there is a difference in the rights and obligations of members in the decision-making (representation, equality of voting powers) regarding the threat thereof or actual withdrawal of members, there is non-compliance with the principle of equality of states. Another aspect for discussion of the principle of equality of states in IGOs with regard to withdrawal is whether international organizations have a withdrawal clause. Namely, founding treaties of IGOs either do or do not provide a withdrawal clause. The League of Nations had a withdrawal clause allowing for any member to withdraw after two years notice under the condition that at the time of withdrawal it has fulfilled all its international obligations and the obligations under the Covenant of the League. ${ }^{278}$ Even 16 members used this clause and as a result there were 16 withdrawals from membership in the League of Nations. ${ }^{279}$ Having a withdrawal clause is in compliance with the principle of equality as it formally respects the sovereign will of states to freely acquire membership or freely terminate membership in an IGO. In cases where there is no withdrawal clause in the founding treaty of an IGO, this usually reflects the negative position of members towards the possibility of withdrawal from membership. It would be difficult to assume that the drafters of the founding treaty had not thought of situations where members would like to terminate their membership. Not having a withdrawal clause however is not a guarantee against it, as shown by a 1987 study recording 46 cases of withdrawal from the specialized agencies of the UN (WHO had 10 withdrawals, UNESCO had 3 prior to 1954). ${ }^{280}$ From a formal legal perspective not having a withdrawal clause is also in compliance with the principle of equality of states as the rule applies equally to all. However, there are arguments that consider this to be contrary to the principle of equality of states as not having a withdrawal clause violates the sovereign will of states to terminate membership in an IGO. Be it as it may, this is of interest to discuss in from the perspective of the principle of equality of states in IGOs.

For a more detailed discussion on the principle of equality of states with regard to suspension, expulsion or withdrawal from membership in the UN, the WTO and the IMF refer to the following chapters. ${ }^{281}$

\section{CONCLUSION}

The principle of equality of states is an "umbrella" type of principle, in that it covers a wide range of matters. The review of its application in international organizations

${ }^{278}$ Covenant of the League of Nations, Article 1, para. 3.

${ }^{279}$ Henry G. Schermers \& Niels M. Blokker, International Institutional Law, Fifth Revised Edition, Martinus Nijhoff Publishers, 2011, pg. 102.

${ }^{280}$ Ibid., pg. 104.

${ }^{281}$ On the application of the principle of equality of states in suspension, expulsion or withdrawal from membership in the UN, see Chapter IV, below, pg. 180-184; in the WTO, see Chapter V, below, pg. 240-241; in the IMF, see Chapter VI, below, pg. 302-303. 
requires a comprehensive approach that would include a number of important aspects. Therefore, the discussion on the application of the principle of equality of states in international organizations should include the following sets of questions: 1 . acquisition of membership; 2. the rights and duties of members; and 3. and the processes limiting or terminating membership rights (suspension, expulsion and withdrawal of membership).

When it comes to the process of acquisition of membership, the discussion on the principle of equality of states in international organizations should include the process of becoming a member through participating in the negotiations on the establishment of the IGO and potentially acquiring original membership, as well as through accession or admission.

With regard to the rights and duties of members, the review should include the equality of states in international organizations in representation, decision-making processes, equality of voting powers and financing of international organizations. Without representation, no state can neither vote in a majority vote, nor block a decision in unanimity or consensus decision-making. In the application of the principle of equality of states with regard to representation, it is important to review whether all members are, or have the potential equally to be, represented in all organs. In compliance with the principle of equality of states, all states should have equal representation or a potential for equal representation.

With regard to decision-making processes, international organizations resort either to unanimity, majority, consensus, or a combination of these decision-making processes. There are authors that consider only unanimity and consensus decision-making to be in compliance with the principle of equality of states and wrongly exclude majority decision-making as a decision-making process in deviation from the principle of equality of states. Majority decision-making, when based on "equal representation and voting power" of all members is also in compliance with the principle of equality of states. When states consented to majority decision-making they also consented to accept decisions that they did not approve. Bearing in mind that all states have equal say in the decision-making process, and that they can equally be part of the "majority" or of the "minority" in the decision adopted, there is no deviation from the principle of equality of states. All the decision-making processes, whether unanimity, consensus or majority are in line with the principle of equality of states, if there is equal representation and voting powers of member states. Therefore, the decision-making process in fact is eventually irrelevant for the application of the principle of equality of states. It is not the decision-making process itself that determines (non)compliance with the principle of equality of states, it is in fact the (in)equality of representation and voting power which determines whether the decision-making process used in an IGO is in (non) compliance with the principle of equality of states.

With regard to voting power, there is compliance with the principle of equality of states as long as there is equal voting power between all states. This proposition is often formulated as the "one state, one vote" principle. The alternative to the one state one 
vote principle is the weighted voting and is not in compliance with the principle of equality of states as any inequality in voting power represents a clear deviation from the principle of equality of states.

While the main focus on the principle of equality of states is on the equality of rights, there is a significant lack of coverage of the principle of equality of states in international organizations when it comes to the equality of duties of states. An obvious reality is that when it comes to financing, economically more advanced states carry a greater financial responsibility. ${ }^{282}$ This has been the case from the time of the League of Nations requiring for the expenses needed for its functioning to be borne by the members "in the proportion decided by the Assembly". ${ }^{283}$

If any weighted voting system represents a deviation from the principle of equality of states in IGOs, so does a weighted financing system where members have different financial obligations toward IGOs.

With regard to suspension, expulsion or withdrawal it is important to review whether all member states are equal in the decision-making process both when the related rules are applied to them, or, if they apply the rules to other members of the IGO.

${ }^{282}$ The United States for example had much greater financial obligations, disproportionate to its voting power in the Inter-American system. See Roberto Herrera, Evolution of Equality of States in the Inter-American System, 61 Polit. Sci. Quart. 90 (1946), pg. 105.

${ }^{283}$ Covenant of the League of Nations, Article 6, para 5. 


\section{CHAPTER IV \\ THE PRINCIPLE OF EQUALITY OF STATES IN THE UNITED NATIONS}

\section{INTRODUCTION}

International law in modern era cannot be understood without referring to the growth and importance of international institutions, of which by far the most important is the United Nations. ${ }^{284}$ The organization is considered to be the "salvation of mankind" "285, "unique, invaluable and indispensible"286 the "world's only truly global and comprehensive organization" 287 or the "world hub of cooperation, humankind's political heart" ${ }^{\text {288 }}$. The importance of the UN originates from the main purposes of the organization: to maintain peace and security, develop friendly relations among nations, achieve international co-operation to solve problems of economic, social, cultural or humanitarian nature, and encourage respect for human rights and freedoms and to be the centre for harmonizing the actions of nations to achieve these goals. ${ }^{289}$

The United Nations (UN) ${ }^{290}$ is considered to be an international organization of a universal character. In terms of membership, this entails that the organization is open to all states. The Vienna Convention on the Representation of States in their Relations with International Organizations of a Universal Character, when defining what it considers to be an "international organization of a universal character", states that it means the:

\footnotetext{
${ }^{284}$ Malcolm N, Shaw, International Law, Sixth Edition, Cambridge University Press, 2008, pg. 47.

${ }^{285}$ Jan Klabbers, 'Contending approaches to International Organizations: Between functionalism and constitutionalism’ in Jan Klabbers and Åsa Wallendahl, Editors, Research Handbook on the Law of International Organizations, Edward Elgar Publishing Limited, 2011, pg. 7.

${ }^{286}$ Ban Ki-moon, Secretary-General of the United Nations, New York, April, 2011, Forward for: Basic Facts about the United Nations, United Nations Department of Public Information, New York, 2011.

${ }^{287}$ Jan Klabbers, Constitutionalism Lite, 1 Int’l. Org. L. Rev. R. 31 (2004), pg. 33.

${ }^{288}$ Kirsten Nakjavani Bookmiller, The United Nations (Global Organizations), Chelsea House Publishers, New York, 2008, pg. 12

${ }^{289}$ United Nations Charter, Article 1.

${ }^{290}$ Formally, the name United Nations was adopted by the Charter which in the Preamble states: "do hereby establish an international organization to be known as the United Nations".
} 
"United Nations, its specialized agencies, the International Atomic Energy Agency and any similar organization whose membership and responsibilities are on a worldwide scale". ${ }^{291}$

However, the term "universal" is criticized by some authors as there is no universal organization that includes all the states of the world. Accordingly, Shcwarzenberger suggests the term "universalist" and Oppenheim on the other hand suggests the concept "of potentially universal character". 292

Though having 193 members and considered to be almost absolutely universal, the UN has always foreseen the possibility that not all existing states are at the same time UN members (a strong example was Switzerland until recently). From its conception, the founders in the Charter made the distinction between UN members and states that are not Members of the organization. ${ }^{293} \mathrm{UN}$ members may also be expelled from membership if certain conditions are met. ${ }^{294}$

The number of potential members is really unknown and no one can guess if the number of states will decrease or more likely increase as was the existing trend was for the last decades. States may come into being as some fall apart, others join into federations and unions, and in the past some even came into being by international organizations supervising processes through the mandates of the League of Nations or the Trusteeship of the UN. ${ }^{295}$

Even today there is the prospect of Kosovo and Taiwan applying for membership of the UN, though Taiwan experienced failure in its 2007 bid. ${ }^{296}$ There is also a similar situation with Palestine and the Holy See, both having the status of permanent observers of the UN. ${ }^{297}$ In fact, the most recent application for membership was made by Palestine on September 23rd 2011. ${ }^{298}$

The application of the principle of equality of states in the UN is rather broad as it is not limited only to the composition, functions and powers of the General Assembly (GA) and the Security Council (SC). The General Assembly and its one member one vote rule, is usually praised as reflecting the application of the principle of equality of

\footnotetext{
${ }^{291}$ Vienna Convention on the Representation of States in their Relations with International Organizations of a Universal Character, 1975, Article 1, paragraph 1, (2).

${ }^{292}$ See C. F. Amerasinghe, Principles of the Institutional Law of International Organizations, Second Edition, Cambridge University Press, 2005, pg. 11.

${ }^{293}$ Herbert W. Briggs, Membership in the Proposed General International Organization, 39 Am. J. Int’l. L. 101 (1945), pg.102.

${ }^{294}$ See United Nations Charter, Article 6 on termination of membership.

${ }^{295}$ On the various modes of state creation of states in international law see: James R. Crawford, The Creation of States in International law, Second Edition, Oxford University Press, 2007, pg. 255-648.

${ }^{296}$ See Thomas D. Grant, Admission to the United Nations: Charter Article 4 and the Rise of Universal Organization, Martinus Nijhoff Publishers, 2009, pg. 162-189.

${ }^{297}$ The position of the Permanent Observers of the UN is based on the practice of the organization and not on the Charter. See: UN web page which has listed both the Holy See and Palestine as Permanent Observers under the "Non-member States and Entities" under the category of Permanent Observers, at" http://www.un.org/en/members/nonmembers.shtml, (visited May 2013).

298 See UN News Centre: Ban sends Palestinian application for membership to Security Council at: http://www.un.org/apps/news/story.asp?NewsID=39722, (visited March 2013).
} 
states, and the veto power of the permanent five in the Security Council is widely regarded as a deviation from the principle of equality of states.

This chapter discusses the application of the principle of equality of states in the United Nations with regard to the: (1) UN Charter; (2) acquisition of membership; (3) decision-making; (4) financing of the UN; and (5) suspension, expulsion and withdrawal from membership of the UN.

\section{THE PRINCIPLE OF EQUALITY OF STATES IN THE UNITED NATIONS CHARTER}

The Charter is considered to be the most important document of the organization. It even has an application beyond that of the UN itself, given the fact that in certain situations it has applications to non UN members and to general in international law. ${ }^{299}$ There are views that the UN Charter is not only the Constitution of the UN, but also of the International Community. ${ }^{300}$

While the Covenant of the League of Nations did not make any reference to the principle of equality of states, the United Nations Charter contains both direct and indirect references. References to the principle of equality of states in the Charter relate not only to the position of Member States in the United Nations but also to the status of the principle of equality of states in international law. ${ }^{301}$ In more specific terms, the Preamble is referring to "equal rights of men and women and of nations large and small",302; Article 1 (2) on friendly relations between nations based on "the principle of equal rights and self-determination" ${ }^{\text {"303; }}$; this phrase is again repeated in Article 55 but with a different area of application; Article 2 (1) with the most relevant provision to this book that the UN is "based on the principle of sovereign equality"304; Article $76 \mathrm{~d}$. stating as the objective of the Trusteeship system to "ensure equal treatment in social, economic and commercial matters for all Members of the United Nation”305; and finally, Article 78 repeating the basic principle of the UN that relationship between UN Members "shall be based on the principle of sovereign equality"306.

\footnotetext{
${ }^{299}$ The position of the UN Charter is also special due to the fact that outside the usual realm of application of constitutions of international organizations only to their Members, the United Nations Charter foresees its application even to non UN Members, or to States that have not signed and ratified the Charter and have not become UN Members. An example is Article 2 (6) of the UN Charter which reads that the "Organization shall ensure that states which are not Members of the United Nations act in accordance with these Principle as so far as may be necessary for the maintenance of international peace and security".

${ }^{300}$ Henry G. Schermers \& Niels M. Blokker, International Institutional Law, Fifth Revised Edition, Martinus Nijhoff Publishers, 2011, pg. 11.

${ }^{301}$ Bruno Simma, Hermann Mosler et al, Editors, The Charter of the United Nations: A Commentary, Second Edition, Volume I, Oxford University Press, 2002, pg. 35.

${ }^{302}$ United Nations Charter, Preamble.

${ }^{303}$ United Nations Charter, Article 1 (2), Article 55.

${ }^{304}$ United Nations Charter, Article 2 (1).

${ }^{305}$ United Nations Charter, Article 76, d.

${ }^{306}$ United Nations Charter, Article 78.
} 
If reviewed in more detail, these references provide for a better picture of their meaning and position in the Charter. The relevant wording of the Preamble sounds surprisingly similar to the wording of the sentence by Vattel discussed in the first chapter $^{307}$, who spoke of equality of men and women by making an analogy from equality of men to the equality of states. It is stated in the Preamble of the Charter that the peoples of the United Nations are determined to: "reaffirm faith in fundamental human rights, in the dignity and worth of the human person, in the equal rights of men and women and of nations large and small". ${ }^{308}$ For Kelsen, "sovereign equality" is not compatible with the Preamble and its wording on "equal rights" as the position of the permanent five is not compatible with "sovereign equality" and the "equal rights of nations large and small". ${ }^{309}$ However, it is also considered that the wording of the Preamble, though not specifically mentioning the principle of equality of states, combines human rights issues ("equal rights of men and women") with the sovereign equality of states ("equal rights of nations large and small"). ${ }^{310}$ The relation to the principle of equality of states here is obvious and it is quite reasonable for authors to link the Preamble and its wording on "equal rights of nations large and small" to the wording of Article 2(1) of the Charter. ${ }^{311}$ As mentioned, Article 2 determining the basic principles of the UN and of its members marks the principle of equality of states as its first basic principle. When comparing the Preamble with the wording of Article 2.1 one should make the distinction that the Preamble speaks of equal rights of "nations" while Article 2.1 speaks of sovereign equality of "members", clearly referring only to the United Nations members. ${ }^{312}$ It is obvious that the approach taken in the Preamble is broader as nations can be UN members but also states that for any reason have not acquired UN membership.

Article 1 of the Charter determines the primary purpose of the UN to be the maintenance of international peace and security and as its second purpose the ideal to: "develop friendly relations among nations based on respect for the principle of equal

\footnotetext{
${ }^{307}$ On the statement introduced by Vattel see Chapter I, above, pg. 42-45. Vattel stated that "since men are by nature equal, and their individual rights and obligations the same, as coming equally from nature, Nations, which are composed of men and may be regarded as so many free persons living together in a state of nature, are by nature equal and hold from nature the same obligation and the same rights. Strength or weakness, in this case, counts for nothing. A dwarf is as much a man as a giant is; a small Republic is no less a sovereign State than the most powerful Kingdom.”

${ }^{308}$ United Nations Charter, Preamble.

${ }^{309}$ Hans Kelsen, The Law of the United Nations: A Critical Analysis of its Fundamental Problems, With Supplement, Stevens \& Sons Limited, 1951, pg. 51.

${ }^{310}$ Bruno Simma, Hermann Mosler et al, Editors. The Charter of the United Nations: A Commentary, Second Edition, Volume I, Oxford University Press, 2002, pg. 35.

${ }^{311}$ United Nations Charter, Article, 2, (1) stating that the "Organization is based on the principle of the sovereign equality of all its Members. See: Franz Cede, 'Historical and Legal Framework for Activities of the United Nations’ in Franz Cede and Lilly Sucharipa-Behrmann, Editors, The United Nations Law and Practice, Kluwer Law International, 2001, pg. 13.

${ }^{312}$ Franz Cede, 'Historical and Legal Framework for Activities of the United Nations' in Franz Cede and Lilly Sucharipa-Behrmann, Editors, The United Nations Law and Practice, Kluwer Law International, 2001, pg. 13.
} 
rights and self-determination of peoples" ${ }^{313}$ The same phrase of "the principle of equal rights and self-determination of peoples" however with greater scope of application is repeated in Article 55 under Chapter IX on International and Economic Social CoOperation. ${ }^{314}$ According to Broms, the application of the principle on equal rights of "peoples" instead of "states" makes this reference in Article 1 as well the identical wording in Article 55 less interesting and not affecting the principle of equality of states. ${ }^{315}$ However, this seems, to be an overstatement to the wording of both Article 1 and 55. Primarily, it seems to overlook that they both speak of developing friendly relations among nations. And by nations, based on the wording of the Charter and common usage one may presume that is used as a synonym for states. ${ }^{316}$ Second, these "nations" develop their relations based on the principle of "equal rights" (which relates to the principle of equality of states). The term "peoples" in relation to "equal rights" probably means "states" as only states may, according to international law have "equal rights". ${ }^{317}$ The wording "self-determination of peoples" though not without exceptions, is also related to the notion of states because only "peoples" are entitled by international law to external self-determination, or to have "a state"; or to internal self-determination as a liberty to decide on their internal political and economic system. ${ }^{318}$ Third, it is obvious that the wording of both Articles 1 and 55 is directed to UN Members which may only be states and which are the only sovereigns to decide on such a broad area of issues. In these lines, Simma notes that Articles 1 (2) and 55 "do not merely address this principle but make it a responsibility of the United Nations to develop friendly relations among nations upon that basis". ${ }^{319}$

The next reference is the one in Article 76 which, when referring to the final objective of the Trusteeship System, speaks of "equal treatment in social, economic, and commercial matters for all Members of the UN" ${ }^{320}$ The wording of Article 76 clearly points out that the end goal of the Trusteeship System for the trust territories is to

\footnotetext{
${ }^{313}$ The reviewed Articles 1 and 2 are part of the Chapter I on the Purposes (Article 1) and Principles (Article 2) of the UN Charter which are applicable to the United Nations and its Members.

${ }^{314}$ Article 55 states that based on the principle of equal rights and self-determination of peoples the UN will promote:

"a. higher standards of living, full employment, and conditions of economic and social progress and development; b. solutions of international economic, social, health, and related problems; and international cultural and educational co- operation; and c. universal respect for, and observance of, human rights and fundamental freedoms for all without distinction as to race, sex, language, or religion. “

${ }^{315}$ Bengt Broms, The Doctrine of Equality of States as Applied in International Organizations, Vammala Kirjapaino, 1959, pg. 162.

${ }^{316}$ Some international organizations are open to "nations" in their constitutions. Such an example is the Food and Agricultural Organization which according to Article 2 of the FAO Constitution is open to "nations".

${ }^{317}$ See Hans Kelsen, The Law of the United Nations: A Critical Analysis of its Fundamental Problems, With Supplement, Stevens \& Sons Limited, 1951, pg. 51-52.

${ }_{318}$ On the principle of self-determination of peoples in international law see Antonio Cassese, Selfdetermination of Peoples, Cambridge University Press, Cambridge, 1995.

${ }^{319}$ Bruno Simma, Hermann Mosler et al, Editors, The Charter of the United Nations: A Commentary, Second Edition, Volume I, Oxford University Press, 2002, pg. 35.

${ }^{320}$ United Nations Charter, Article 76, d.
} 
achieve a situation of statehood and equality. This is a very clear statement referring to the principle of equality of states, which is often overlooked. ${ }^{321}$

Article 78 dealing with trusteeship system states that:

"The trusteeship system shall not apply to territories which have become Members of the United Nations, relationship among which shall be based on respect for the principle of sovereign equality. "322

Article 78 seems to make a clear statement that relations between Members of the UN are in fact relations between sovereign states, which are based on the principle of equality, and that this principle is not applicable to governed territories of the trusteeship system by the mere fact that they have not achieved statehood yet. ${ }^{323}$

To sum up, there are direct references to the principle of equality of states in the UN Charter. However, as it will be discussed in the following sections, there is non compliance with the application of the principle of equality of states for example in the Security Council when it comes to representation and voting powers.

\section{ACQUISITION OF MEMBERSHIP IN THE UNITED NATIONS}

Chapter II of the Charter titled "membership” deals with the membership issues of the United Nations. Based on the Charter, a State may acquire membership through original membership or through the admission process. Acquisition of membership of the United Nations has had a profound effect on the enlargement of the organization. In terms of membership, the UN started with rather modest numbers compared to its constant growth by, on average, 2.15 additional members every year for almost seven decades now. ${ }^{324}$ In numbers, what began with the original 51 members had, by 1960, almost doubled to 99 members; by 1978 membership had almost tripled to 151 members, and now has almost quadrupled, to achieve near full universality, with South Sudan (the 193rd member) being the most recent to join, in July of $2011 .^{325}$

\footnotetext{
${ }^{321}$ For example, Broms in his review of the Charter in light of the principle of equality of states does not mention it at all. See Bengt Broms, The Doctrine of Equality of States as Applied in International Organizations, Vammala Kirjapaino, 1959, pg. 162-166. Neither does Bruno Simma, Hermann Mosler et al, Editors, The Charter of the United Nations: A Commentary, Second Edition, Volume I, Oxford University Press, 2002, pg. 35. Efraim on the other hand speaks only of Article 2, para. 1 without mentioning any of the other references mentioned in the Charter. See Athena Debbie Efraim, Sovereign (In)equality in International Organizations, Martinus Nijhoff, The Hague, 2000, pg. 100-107.

${ }^{322}$ United Nations Charter, Article 78.

${ }^{323}$ According to some authors, membership in the United Nation is understood as the ultimate proof that a particular subject of international law is a state. See Christian Hillgruber, The Admission of New States to the International Community, 9 Eur. J. Int. L. 491 (1998), pg. 492.

${ }^{324}$ Around half of the increase of new members was the result of the decolonization process resulting in almost 100 new States. This had a profound effect in the composition of membership in the General Assembly and as a consequence to a more limited scope in the form of non permanent membership in the Security Council as well as membership to other UN organs and bodies.

${ }^{325}$ See UN web page for a detailed overview of UN members in an alphabetical order with information on the date of acquisition of membership, at http://www.un.org/en/members, (visited May 2013).
} 
This increase in UN membership can be better illustrated in the following chart: 
Chart 4: Increase in UN membership through the years

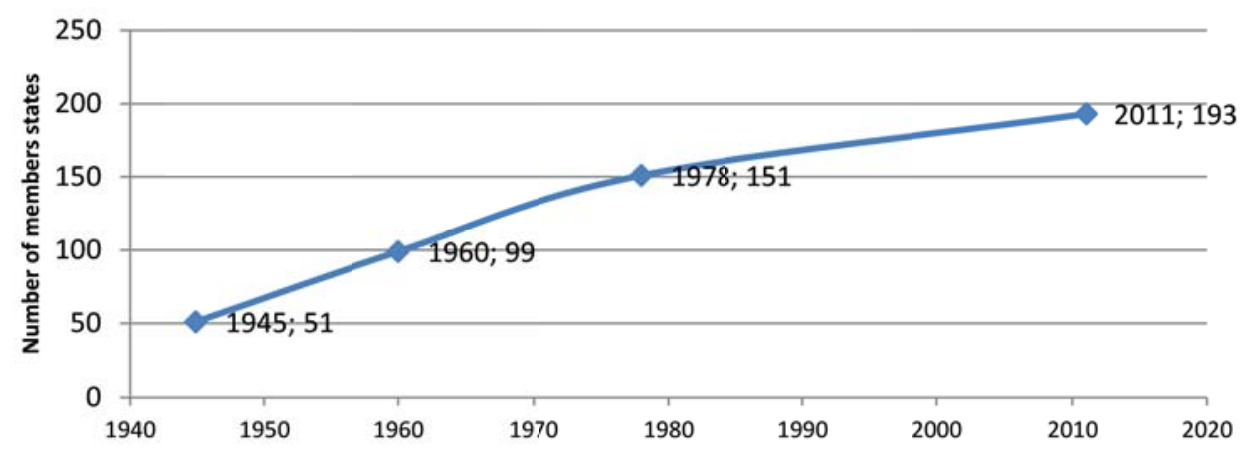

Some of the original members such as Yugoslavia, Czechoslovakia, and USSR in the meantime ceased to exist. The countries that succeeded them did go through the admission process except for the USSR, which was succeeded by Russia as an original member. While the admission of new Members is a possibility without any time limitations, the possibility for acquiring original membership is not possible anymore as it existed only for a certain number of states participating in the preparatory work and only for a certain period of time. After acquiring UN membership, the Charter does not make the distinction between original and non-original members in their rights and obligations. Each of these categories of UN Members acquired membership through two distinctive membership processes with different consequences in terms of the application of the principle of equality of states and will thus be reviewed separately. The following sections will discuss first the principle of equality of states in the negotiations for the establishment of the United Nations, second original membership in the UN acquired through participation in the negotiations and third, acquisition of membership through the admission process.

\section{THE PRINCIPLE OF EQUALITY OF STATES IN THE NEGOTIATIONS FOR THE ESTABLISHMENT OF THE UNITED NATIONS}

The application of the principle of equality of states in the United Nations in great deal if not entirely was conditioned by the preparatory work of the organization whose outcome was the United Nations Charter. With regard to the negotiations for the establishment of the United Nations, it is important to see if and how the principle of equality of states influenced the United Nations in the early stages of its foundation through the participation of states in the negotiations and the role of the principle of equality of states in these negotiations. At the outset, it should be noted that this has not received sufficient attention by scholars. In fact, as stated in a recent book in 2003, "the Act of Creation" by Stephen Schlesinger, the origins of the establishment of the UN have not 
been reviewed sufficiently. ${ }^{326}$ Secretary General Kofi Annan, at the occasion of a lecture on Schlesinger's book at the UN in October of 2006, illustrated best this situation:

"this book takes us where no historian has fully gone before, many books have contained chapters or passages on the San Francisco Conference, some participants have mentioned it in their memoires, but there has never been a comprehensive account dedicated solely to this landmark effort, the act of creation is that book filling a major gap and giving us a riveting story of our own organization., 327

Having this in mind, it should not come as a surprise that if there was a shortage of scientific coverage of the history of the establishment of the UN, it is quite natural that there is a shortage of coverage of the role of the principle of equality of states in the making of the UN.

Historically, the origins of the United Nations can be traced from the times of the Second World War. The preparatory work was not done in a single meeting, but rather in a series of meetings held in different parts of the world with different participants. The various instruments produced at these meetings (agreement, declaration, Charter) contain direct as well as indirect references to the principle of equality of states. State participation varied from one meeting to the other ranging from bilateral, plurilateral and multilateral. Only the United States and the United Kingdom participated fully in each and every meeting. ${ }^{328}$ On the other hand, the Soviet Union did not participate in all the meetings for establishing the organization. ${ }^{329}$ It is considered that the USSR played a relatively minor role in the establishment of the UN but that it was quite vocal in establishing the veto powers for the permanent five. ${ }^{330}$

More comprehensive references to the preparatory work usually include the following eight major events stated here in chronological order: the Inter-Allied Declaration of June 1941, the Atlantic Charter of August 1941, the Declaration by United Nations of January 1942, the Moscow Conference of October 1943, the Teheran Conference of December 1943, the Dumbarton Oaks Conference of September-October

\footnotetext{
${ }^{326}$ On the history of UN's establishment see: Stephen Schlesinger, Act of Creation: The Founding of the United Nations: A Story of Superpowers, Secret Agents, Wartime Allies and Enemies, and Their Quest for a Peaceful World, Westview Press, 2003.

${ }^{327}$ Kofi A. Annan, quote stated from the lecture given on 11 October 2006 on the occasion of the UN Secretary General's hosting the lecture of the author Stephen Schlesinger on his book: The Act of Creation: The Founding of the United Nations. Available on the UN web site at: http://www.un.org/webcast/sg2006.html, (visited March 2013).

${ }^{328}$ President Roosevelt at the beginning was thinking that the world order after the war will be determined by the USA and UK alone without the need to include other powers. See Helmut Volger, 'History of the Foundations of the UN' in Helmut Volger, Editor, A Concise Encyclopedia of the United Nations, Second Revised Edition, Martinus Nijhoff Publishers, 2010,pg. 218.

${ }^{329}$ The Soviet Union did not participate in the Inter-Allied meeting of June 1941 in London nor the Atlantic Charter of August 1941 held somewhere in the Atlantic. However it did participate in all meetings onward from the Declaration by United Nations up to the establishment of the United Nations in San Francisco.

${ }^{330}$ Antonio Cassese, International Law, Second Edition, Oxford University Press, 2005, pg. 318.
} 
1944, the Yalta Conference of February 1945, and concluding with the San Francisco Conference of April 1945. Each of them on its own merits influenced the application of the principle of equality of states in the Charter.

\section{A. THE INTER-ALLIED MEETING}

Historically, the first origins of the United Nations are usually related to the Inter-Allied meeting of June 12, 1941 held in London with the participation of fourteen allies. ${ }^{331}$ The result of the meeting was the St. James Agreement in which the Allies presented their determination to continue to fight against German and Italian oppression. ${ }^{332}$ They also expressed their position that the cooperation of the free peoples is important and that all can enjoy economic and social security by working together both in peace and in war. ${ }^{333}$

Other than this, no specific references to the principle of equality of states were given in the St. James Agreement.

\section{B. THE ATLANTIC CHARTER}

The following step was the Atlantic Charter ${ }^{334}$, representing one of the most significant stages of the preparatory work for the establishment of the United Nations. The Atlantic Charter made the decisive step for the establishment of the new international organization as it spoke of a universal security system. ${ }^{335}$

The Atlantic Charter was the result of a bilateral meeting in 1941 between President Roosevelt and Prime Minister Churchill. The preliminary draft of the Atlantic Charter (written by Churchill) contained wording such as "effective international organizations" as well as "a fair and equal distribution of essential produce”. ${ }^{336}$ According to the Encyclopedia of the United Nations, Churchill favored an international organization based on the League of Nations as a model to be supplemented by the principle of regional representation, while Roosevelt's opinion, which eventually prevailed, was in favor of the US and the UK having the leading position in the new

\footnotetext{
${ }^{331}$ The following states were present: UK of Great Britain and Northern Ireland, Canada, Australia, New Zealand and South Africa, the Government of Belgium, the Provisional Czechoslovak Government, the Government of Greece, Luxemburg, the Netherlands, Norway, Poland and Yugoslavia, and the Representatives of General de Gaulle, leader of Free Frenchmen. See St. James Agreement of June 12, 1941, Inter-Allied Meeting, held in London at St. James's Palace on June 121941.

${ }^{332}$ See St. James Agreement of June 12, 1941, Inter-Allied Meeting, held in London at St. James's Palace on June 12 1941, Point 1.

${ }^{333}$ See St. James Agreement of June 12, 1941, Inter-Allied Meeting, held in London at St. James’s Palace on June 12 1941, Point 3.

${ }^{334}$ Joint Declaration of the President of the United States of America and the Prime Minister of the United Kingdom of Great Britain and Northern Ireland of August 14, 1941 known as the "Atlantic Charter".

${ }^{335}$ Franz Cede, 'Historical and Legal Framework for Activities of the United Nations' in Franz Cede and Lilly Sucharipa-Behrmann, Editors, The United Nations Law and Practice, Kluwer Law International, 2001, pg. 6.

${ }^{336}$ Gerry Simpson, Great Powers and Outlaw States Redux, 43 Neth. YBIL 83 (2013), pg. 91.
} 
organization. ${ }^{337}$ In the Atlantic Charter they settled for eight fundamental principles through which they:

"deem it right to make known certain common principles in the national policies of their respective countries on which they base their hopes for a better future for the world". 338

These principles are a clear statement of the positions of the US and UK. The fourth principle of the Atlantic Charter is relevant for the principle of equality of states, and it reads:

"fourth, they will endeavor (US and UK), with due respect for their existing obligations, to further the enjoyment by all States, great or small, victor or vanquished, of access, on equal terms to the trade and to the raw materials of the world which are needed for their economic prosperity". 339

This reference is clear in regard to equality of states as it speaks of equality ("access on equal terms"), for every State regardless of size ("great and small”) but even more importantly regardless of their side in the war ("victor or vanquished") to trade and raw materials. Although this refers in scope only to trade and raw minerals, this restriction does not diminish the statement's significance to the principle of equality of states. Adherence to the Atlantic Charter was formally declared at the Second Meeting of the Inter-Allied Councils where the Netherlands Foreign Minister, Dr. van Kleffens (referring to the reference on equality of states) expressed the position that there should be

"no important exceptions to the general rule of free access to trade and raw materials on the basis of equal opportunities for all, otherwise this principle would degenerate into a fine phrase as it did following the last war".340

\section{THE DECLARATION BY UNITED NATIONS}

Following the previous bilateral conclusion of the Atlantic Charter, the next meeting gathered the participation of twenty six nations. ${ }^{341}$ They expressly supported the Atlantic Charter (including its fourth principle) and signed the "Declaration by United Na-

\footnotetext{
${ }^{337}$ Helmut Volger, 'History of the Foundations of the UN' in Helmut Volger, Editor, A Concise Encyclopedia of the United Nations, Second Revised Edition, Martinus Nijhoff Publishers, 2010, pg. 216.

${ }^{338}$ Atlantic Charter, August 14, 1941 signed by the US president Franklin D. Roosevelt and the UK Prime Minister, Preamble.

${ }^{339}$ Atlantic Charter, August 14, 1941 signed by the US president Franklin D. Roosevelt and the UK Prime Minister, Fourth Point.

${ }^{340}$ Inter-Allied Council Statement on the Principles of the Atlantic Charter, September 24, 1941. See Department of State Bulletin, September 27, 1941.

${ }^{341}$ A joint declaration by: United States, United Kingdom, the Soviet Union, China, Australia, Belgium, Canada, Costa Rica, Cuba, Czechoslovakia, Dominican Republic, El Salvador, Greece, Guatemala, Haiti, Honduras, India, Luxembourg, Netherlands, New Zealand, Nicaragua, Norway, Panama, Poland, South Africa and Yugoslavia.
} 
tions" in 1942 in Washington. ${ }^{342}$ The "Declaration by the United Nations" contained for the first time in an official document the name "United Nations" which was coined by Franklin D. Roosevelt. ${ }^{343}$

In regard to the principle of equality of states, this meeting was important for at least three aspects. First, while the Declaration itself did not contain any specific reference to the principle of equality of states, the participant countries subscribed to the principles of the Atlantic Charter (including the fourth principle on the participation of all states, great and small, victor or vanquished). The second important aspect is that the 26 countries that signed the "Declaration by the United Nations" and their work was recognized as preparatory work for the establishment of the UN. This of course enabled them to get access to membership by participating in the preparatory work rather than by the admission process, which requires specific conditions to be met by the applicant states as well as a positive judgment by the organization.

Third, the special position of the US, UK and USSR and China was shown by the fact they were the first to sign the Declaration, outside of alphabetical order as Roosevelt was recorded to have said that the USSR would have objected to be listed below some of the states not contributing to the war as they were. ${ }^{344}$ During the remaining part of the war, an additional 21 countries joined the original 26 countries in signing the Declaration by the United Nations. ${ }^{345}$

\section{THE MOSCOW CONFERENCE}

From the twenty six participating countries in Washington the following meeting in Moscow in 1943 was held with the participation of four states only: the Soviet Union, United Kingdom, United States and China. ${ }^{346}$ They were represented by their Ministers of Foreign Affairs except for China which was represented by its ambassadors. In fact, China only later signed the Declaration prepared by the major three powers. ${ }^{347}$ As a result of the Moscow conference the participating nations adopted the Joint Four Nation Declaration. ${ }^{348}$ It was not until this conference in Moscow that there was a formal

${ }^{342}$ See the Declaration by the United Nations, January 1, 1942.

${ }^{343}$ Basic Facts about the United Nations, United Nations Department of Public Information, New York, 2011, pg. 3.

${ }^{344}$ Robert C. Hilderbrand, Dumbarton Oaks: The Origins of the United Nations and the Search for Postwar Security, The University of North Carolina Press, 1990, pg. 16.

${ }^{345}$ The following countries joined the original 26 countries: Philippines, Mexico, Ethiopia, Iraq, Brazil, Bolivia, Iran, Columbia, Liberia, France, Ecuador, Peru, Chile, Paraguay, Venezuela, Uruguay, Turkey, Egypt, Saudi Arabia, Lebanon and Syria.

${ }^{346}$ What initially began with bilateral cooperation between the US and the UK became more of a plurilateral nature with the participation of the USSR and China in the discussions. This was not an easy decision as there were doubts about increasing the number of participating states especially with regard to the participation of China which was under Japanese occupation. See: Helmut Volger, 'History of the Foundations of the UN' in Helmut Volger, Editor, A Concise Encyclopedia of the United Nations, Second Revised Edition, Martinus Nijhoff Publishers, 2010, pg. 218-219.

${ }^{347}$ Peter R. Baehr and Leon Gordenker, The United Nations: Reality and Ideal, Fourth Edition, Palgrave Macmillan 2005, pg. 15.

${ }^{348}$ The Moscow Conference, October 1943, Joint Four-Nation Declaration. 
decision to establish an international organization. ${ }^{349}$ The Declaration made a clear call for establishing an international organization, marking the first formal document with such a goal. The Moscow Conference gave a very strong statement in regard to the principle of equality of states and more importantly to its application in the United Nations. The Declaration stated that:

"they recognize the necessity of establishing at the earliest practicable date a general international organization, based on the principle of the sovereign equality of all peace-loving states, and open to membership by all such states, large and small, for the maintenance of international peace and security". ${ }^{350}$

In fact this sentence was already drafted before, but was amended by inserting the words "peace loving" between "all" and "States", in order to make sure that the enemy states will not automatically qualify for membership. ${ }^{351}$

\section{E. THE TEHERAN CONFERENCE}

The next meeting was held in Teheran in 1943 with the participation of the three most important countries of the Moscow conference, the UK, US and the Soviet Union (China did not participate). President Roosevelt, Prime Minister Churchill and Premier Stalin again affirmed their goal to establish the international organization. The Teheran Conference stated: "we shall seek the cooperation and active participation of all nations, large and small... We will welcome them, as they may choose to come, into a world family of Democratic Nations." 352

In the meantime, in the most organized effort for drafting the Charter, the US Secretary of State Cordell Hull established a special committee of advisors with the sole purpose of drafting the proposal for the founding treaty of the new international organization, which eventually served as the outline for the UN Charter itself.

Under Hull, a document named "Charter of the UN", containing for the very first time the term Charter as the name of the constitutional document of the new international organization appeared in $1943 .{ }^{353}$ For his efforts in establishing the United Nations, Cordell Hull received the Nobel Peace Prize in $1945 .{ }^{354}$

\footnotetext{
${ }^{349}$ Benedetto Conforti and Carlo Focarelli, The Law and Practice of the United Nations, Fourth Revised Edition, Martinus Nijhoff Publishers, 2010, pg. 2.

${ }^{350}$ The Moscow Conference, October 1943, Joint Four-Nation Declaration, Point Four.

${ }^{351}$ Helmut Volger, 'History of the Foundations of the UN' in Helmut Volger, Editor, A Concise Encyclopedia of the United Nations, Second Revised Edition, Martinus Nijhoff Publishers, 2010, pg. 219.

${ }^{352}$ The Tehran Conference, November 28-December 1, 1943, The Declaration of the Three Powers, December $1,1943$.

${ }^{353}$ Bruno Simma, Hermann Mosler et al, Editors, The Charter of the United Nations: A Commentary, Second Edition, Volume I, Oxford University Press, 2002, pg. 4.

354 See "The Nobel Peace Prize 1945", the official web page of the Nobel Prize available at: http://www.nobelprize.org/nobel_prizes/peace/laureates/1945/, (visited March 2013).
} 


\section{F. THE DUMBARTON OAKS CONFERENCE}

The US, UK, USSR and China were present at Dumbarton Oaks in Washington D.C., in the framework of the "Washington Conversations on International Peace and Security Organization" or the Dumbarton Oaks Conference. The quartet did not have joint meetings as the US and UK representatives met separately first with representatives of the USSR from August 21st until September 28th and then they met with representatives of China from September 29th until October 7th. It was not until the Dumbarton Oaks Conference that the real blueprint of the United Nations called the "Proposal for the Establishment of a General International Organization” was produced. The proposal contained all the essential aspects of the United Nations as it exists today in terms of the goals of the organization, the basic structure and organs. ${ }^{355}$

It resembled the League of Nations and yet at the same time was quite different. The idea of the Big Five in the Council (now besides the US, USSR, UK, China, also France was on board) and their unanimous consent for passing decisions was supported, though the voting details were not yet established. ${ }^{356}$ The special position of the major powers and the diminishing value of the General Assembly in comparison to the position of the Assembly of the League of Nations were not good signs for the application of the principle of equality of states in the new organization. A compromise was made with the principle of equality of states by proposing to have the non-permanent members become the majority in the Security Council. However, while decreasing inequality through greater representation, this solution did not provide any a substantive balance as it did not influence the decision-making powers equally. In terms of the remaining organs of the United Nations the Dumbarton Oaks proposal foresaw, next to the General Assembly, the establishment of the Economic and Social Council (ECOSOC) as well as majority (instead of unanimity) decision-making in the General Assembly and the Economic and Social Council. ${ }^{357}$ The debate on the Security Council composition and voting powers unfortunately was not the only contested issue.

Representation in the General Assembly was also under review after the request by the Soviet Union for additional 16 votes to represent its Republics. ${ }^{358}$ In addition, there was the issue whether the Philippines and India could become members of the United Nations though at the time they had not yet achieved their independence. ${ }^{359}$ Such a

\footnotetext{
355 Benedetto Conforti and Carlo Focarelli, The Law and Practice of the United Nations, Fourth Revised Edition, Martinus Nijhoff Publishers, 2010, pg. 2.

${ }^{356}$ Edwin Borchard, The Dumbarton Oaks Conference, 39 Am. J. Int'l. L. 97 (1945), pg. 98-99.

357 Benedetto Conforti and Carlo Focarelli, The Law and Practice of the United Nations, Fourth Revised Edition, Martinus Nijhoff Publishers, 2010, pg. 3.

${ }^{358}$ Alison Duxbury, The Participation of States in International Organizations, the Role of Human Rights and Democracy, Cambridge University Press, 2011, pg. 84-85. Also see: Peter R. Baehr and Leon Gordenker, The United Nations: Reality and Ideal, Fourth Edition, Palgrave Macmillan 2005, pg. 16; Antonio Cassese, International Law, Second Edition, Oxford University Press, 2005, pg. 318.

${ }^{359}$ A. J. R. Groom, 'Getting to 'Go': The Birth of the United Nations System', in Paul Taylor and A. J. R. Groom, Editors, The United Nations at the Millennium: The Principal Organs, Continuum International Publishing Group, 2000, pg. 14.
} 
possibility was not accepted well by the rest and it was to be decided in future meetings together with a solution on the voting in the Security Council.

\section{G. THE YALTA CONFERENCE}

From the Dumbarton Oaks, the representatives of the US, UK, Soviet Union and China submitted the proposal to the following meeting at a conference known as the Yalta Conference. Stalin, Roosevelt and Churchill during February 1945 reached an agreement on granting veto powers to the permanent five in the SC. The position of the USSR on the issue was rather strong. On this occasion Stalin stated that "he would never agree to having any action of any of the Great Powers submitted to the judgment of the small powers" on which Roosevelt and Churchill substantially agreed and that the "main thing was to prevent quarrels in future between Great Powers and the task, therefore, was to secure their unity for the future". ${ }^{360}$ These positions clearly show that the main concern of the Great Powers was how to ensure their superior position in the organization. In reality, very soon after this meeting the relations between them deteriorated resulting in a long lasting Cold War affecting most of the world. ${ }^{361}$

The Yalta Conference was very important to the application of the principle of equality of states as from this moment on the veto power would be known as the "Yalta Formula". The veto, if not the greatest of all, was a major deviation from the principle of equality of states. In addition, at the Conference the big three also reached an agreement to organize the next meeting in the US and an agreement on the nations to be invited. ${ }^{362}$ They decided on summoning a "United Nations Conference on the proposed world organization" which also specified the nations to participate in the conference. ${ }^{363}$ The invitations were made also on behalf of China and France though neither of them was present in Yalta. Of course in the list of states to be invited there was no room for the enemy states, which may have been historically unavoidable at the time, but which left a number of important powers outside the UN.

Due to demands by the USSR for greater participation, the leaders also reached an agreement to admit as original members Ukraine and White Russia (present Belorussia) as a concession to Stalin. This again, was another blow to the principle of equality of states for a number of reasons: first they were not states but Republics of the USSR; second, they were to be admitted as original members, again giving them special treatment in comparison to the "real" original members; third, they were given a better treatment than the states later to become members through the admission process; and lastly, they even became non-permanent members of the Security Council while they

${ }^{360}$ Antonio Cassese, International Law, Second Edition, Oxford University Press, 2005, pg. 319, 322.

${ }^{361}$ As Churchill stated in the spring of 1946 in Fulton, Missouri, "an Iron Curtain has descended across the continent" marking the end of the alliance and the beginning of the Cold War. See "Iron Curtain Speech" by Winston Churchill at Westminster College, Fulton, Missouri, USA, March 5, 1946.

${ }^{362}$ The list included the United Nations states as existed on 8 February 1945, the associated Nations that have declared war to the common enemy by 1 March 1945 (8 associated Nations and Turkey).

${ }^{363}$ See the Protocol of proceedings of Crimea Conference, February 1945. 
were Republics of USSR, a position that even today 72 UN Member States have not yet accomplished.

The Yalta Conference not only created the "Yalta Formula" (granting veto power), but it also established the list of those states whose participation in the San Francisco meeting would grant them original member status. Beyond this, the exclusion of the non Allied Powers and the admission of Ukraine and Belorussia the Yalta Conference thus far made the most serious deviation from the principle of equality of states in a single meeting.

\section{H. THE SAN FRANCISCO CONFERENCE}

From a formal perspective the San Francisco Conference was the most important meeting for the establishment of the United Nations as the Charter was signed at the conclusion of the conference on 26 June 1945. One may state that the UN was conceived by the USSR, UK and US at the Dumbarton Oaks, refined by Roosevelt, Stalin and Churchill at Yalta, and molded a year later into a Charter at the San Francisco Conference. ${ }^{364}$ It was probably the greatest of any conference known to the world with more than 2500 correspondents of the media covering the 260 representatives coming from 50 states, each having one vote. ${ }^{365}$ The 45 states were invited by the four sponsoring countries, US, UK, USSR and China, and France, which had initially declined the offer to be a sponsor and yet its diplomacy was associated to the Great Powers. ${ }^{366}$ Poland did not participate at the conference and signed the Charter later on. ${ }^{367}$ Though not participating at the conference, Poland together with the fifty participating states was given the status of original members of the United Nations. The full lead of the Big Five and especially of the primary three powers the US, UK and USSR in drafting the new ideas for the organization and preparing them prior to the San Francisco eventually resulted with these ideas becoming the keystones of the Charter. ${ }^{368}$ In addition to Belarus and Ukraine, India and the Philippines were not independent states at the time either. India was a colony of Great Britain and the Philippines was a protectorate of the United States. ${ }^{369}$ Also, France considered Lebanon and Syria as still under its mandate. ${ }^{370}$

\footnotetext{
${ }^{364}$ Frederic L. Kirgis, Jr., The Security Council’s First Fifty Years, 89 Am. J. Int'l. L. 506 (1995), pg. 506.

365 Peter R. Baehr and Leon Gordenker, The United Nations: Reality and Ideal, Fourth Edition, Palgrave Macmillan 2005, pg. 17.

${ }^{366}$ A. J. R. Groom, 'Getting to 'Go': The Birth of the United Nations System', in Paul Taylor and A. J. R. Groom, Editors, The United Nations at the Millennium: The Principal Organs, Continuum International Publishing Group, 2000, pg. 16.

${ }^{367}$ Poland did not participate as it was not clear which government would have the authority to represent the country. The issue was not settled by the Great Powers and as a result Poland did not participate in the conference.

${ }^{368}$ Peter R. Baehr and Leon Gordenker, The United Nations: Reality and Ideal, Fourth Edition, Palgrave Macmillan 2005, pg. 5.

${ }^{369}$ Benedetto Conforti and Carlo Focarelli, The Law and Practice of the United Nations, Fourth Revised Edition, Martinus Nijhoff Publishers, 2010,pg. 4.

${ }^{370}$ Bengt Broms, The Doctrine of Equality of States as Applied in International Organizations, Vammala Kirjapaino, 1959, pg. 172.
} 
Aware of its huge population, although not independent yet, India proposed population size to be taken into consideration when selecting nonpermanent members. ${ }^{371}$

At the end of the conference, in line with the principle of equality of states, the United Nations Charter was adopted unanimously. ${ }^{372}$ It came into force only after being signed and ratified first by the permanent five: China, France, the USSR, the UK and the US. ${ }^{373}$ The fortunate aspect in this unfortunate period of human history is that the opportunity of having a public opinion in favor of an international organization of such magnitude was seized and the United Nations was established. The San Francisco Conference was in line with the principle of equality of states with its one vote per member, the unanimity in adopting the Charter, the key position of the principle of equality of states in the Charter. However, at the same time it also represented a setback for a number of reasons. Contrary to the League of Nations, which did not close its doors to the former enemies, the United Nations original membership turned into "victors organization where foes had no place". ${ }^{374}$ The participating states, especially due to the historic circumstances of the time, were forced to compromise by granting a special position to the major powers. This has continued to haunt the organization ever since. In an article reviewing the tension between the Great Powers and the rest of the states, Simpson makes a parallel in history by stating that many of the debates about the recent reform of the United Nations are replayed in the same type of tensions between these states. ${ }^{375}$

\section{ORIGINAL MEMBERS AND THE APPLICATION OF THE PRINCIPLE OF EQUALITY OF STATES}

The original members, as mentioned, represent states that either participated in the United Nations Conference on International Organization in San Francisco ${ }^{376}$, or who

\footnotetext{
${ }^{371}$ Geoffrey McNicoll, Population Weights in the International Order, 25 Popul. Dev. Rev. 411 (1999), pg. 419.

${ }^{372}$ Franz Cede, 'Historical and Legal Framework for Activities of the United Nations' in Franz Cede and Lilly Sucharipa-Behrmann, Editors, The United Nations Law and Practice, Kluwer Law International, 2001, pg. 7. ${ }^{373}$ United Nations Charter, Article 110, para. 3.

374 Konstantinos D. Magliveras, 'Membership in international organizations' in Jan Klabbers and Åsa Wallendahl Editors, Research Handbook on the Law of International Organizations, Edward Elgar Publishing Limited, 2011, pg. 86.

${ }^{375}$ Gerry Simpson, The Great Powers, Sovereign Equality and the Making of the United Nations Charter, 21 Aust. YBIL 133 (2000), pg. 135.

${ }^{376}$ The participating states were: Argentina, Australia, Belgium, Bolivia, Brazil, Belarus, Canada, Chile, China, Colombia, Costa Rica, Cuba, Czechoslovakia, Denmark, Dominican Republic, Ecuador, Egypt, El Salvador, Ethiopia, France, Greece, Guatemala, Haiti, Honduras, India, Iran, Iraq, Lebanon, Luxembourg, Mexico, Netherlands, New Zealand, Nicaragua, Norway, Panama, Paraguay, Peru, Philippines, Saudi Arabia, Syria, Turkey, Ukrainian Soviet Socialist Republic, South Africa, USSR, UK, USA Uruguay, Venezuela, Yugoslavia. Four participants: Argentina, Belarus, Denmark and Ukraine were invited to participate at San Francisco after the Conference had already convened. See Repertory of Practice of UN Organs Extracts relating to Article 3 of the United Nations Charter, (1945-1954), volume 1, available at http://untreaty.un.org/cod/repertory/art3.html, (visited May 2013).
} 
had previously signed the Declaration of the United Nations ${ }^{377}$ by 1 January 1942 and signed and ratified the Charter. ${ }^{378}$ The states invited to San Francisco, according to the will of the major three powers, were privileged as the Charter gave them original membership status of the UN by stating that original members "shall be states which, having participated in the United Nations Conference on International Organization at San Francisco..”. ${ }^{379}$ The 26 countries that signed the "Declaration by the United Nations" as well and their work formally was recognized as preparatory work for the establishment of the UN ${ }^{380}$ The preparatory work counted as an entry ticket for acquiring membership. However, it was conditioned by the signature and ratification of the UN Charter by any of the states entitle to original membership. By not specifying the states entitled to original membership, the UN Charter avoided the technical mistake of the Covenant of the League of Nations which enumerated the specific signatory states entitled for original membership in the Annex. ${ }^{381}$ The position of original members was primarily reserved to the future permanent members of the UN Security Council and to their judgment on the countries to be invited to the San Francisco Conference. This means that the original members are not only the countries that signed the Charter comprising the necessary number to come into force but also the ones that ratified the Charter after 24 October 1945, such as the Netherlands which ratified it on 10 December $1945 .^{382}$ Under USSR pressure, it was decided at the Yalta Conference that the UK and the US would support the admission of Ukraine and White Russia (today's Belorussia). ${ }^{383} \mathrm{~A}$ similar situation was also present with India, which at the time was also not independent. The admission as original members of Lebanon, Syria and the Philippine Commonwealth was also troublesome as their statehood was questioned. This was a major departure of the principle of equality of states as they were obviously not states. According to Broms, this was not a deviation from the doctrine of equality of states because they were granted original membership with the same rights and duties as the others. ${ }^{384}$ Yet this is a deviation from the principle of equality of states in regard to states which acquired membership through admission in a process which at times was prolonged for political reasons between the USSR and the USA. This was the case on

\footnotetext{
${ }^{377}$ Some States such as Ukraine, Belarus, Lebanon, Syria, Argentina, became original members with participation at San Francisco although had not signed the Declaration by the United Nations of 1942, See Hans Kelsen, The Law of the United Nations: A Critical Analysis of its Fundamental Problems, With Supplement, Stevens \& Sons Limited, 1951, pg. 8.

${ }^{378}$ United Nations Charter, Article 3.

${ }^{379}$ United Nations Charter, Article 3.

${ }^{380}$ United Nations Charter, Article 3.

${ }^{381}$ This included the United States as original member as well, though the United States never ratified the treaty. See Hans Kelsen, Membership in the United Nations, 46 Colum. L. Rev. 391 (1946), pg. 392.

${ }^{382}$ Blokker, Niels, International Organizations and Their Members, 1 Int'l. Org. L. Rev. 139 (2004), pg. 141.

383 "When the conference on world organization is held, the delegates of the United Kingdom and United States of America will support a proposal to admit to original membership two Soviet Socialist Republics, i.e., the Ukraine and White Russia." See: Protocol of Proceedings of Crimea Conference. Section I World Organization, 2 (b).

${ }^{384}$ Bengt Broms, The Doctrine of Equality of States as Applied in International Organizations, Vammala Kirjapaino, 1959, pg. 173.
} 
top of the fact that their statehood was not contested. It is also a deviation from the principle of equality of states with regard to other subjects with similar legal status (for example other USSR Republics or Yugoslav Republics for that matter) that did not have access to membership.

This division created the first inequality between states in terms of acquiring membership of the United Nations because it was not a possibility for many states to participate in the preparatory work. The other departure from the principle of equality of states was as a result of the fact that the UN originated at times when the world was divided between the axis powers and the allies. ${ }^{385}$ While from a moral point of view fully justified, from the formal perspective of the application of the principle of equality of states this created inequality among states as a number of important countries such as Japan, Germany and Italy did not have the opportunity to become original members. This most probably would have not been the case if the UN as a universal organization would have been established in some other time in history. Another evidence of inequality of states in that, among the original Members under Article 110 of the Charter, the signatures of permanent Members have a specific order in the Charter. ${ }^{386}$ Finally, for all the states not participation in the negotiations and not having the opportunity to become original members, the United Nations Charter was drafted and adopted. They were not in position to influence the outcome except through an amendment or a revision procedure. It should be noted that while not written in stone, it is in fact extremely difficult to amend or revise the Charter. ${ }^{387}$

\section{ADMISSION TO THE UNITED NATIONS}

In order to ensure universality, there were voices that proposed automatic membership of states in the organization, ipso facto without accession or admission entailing compulsory membership. ${ }^{388}$ Quite naturally, this was not supported by the majority of states as it would have violated existing international law and the independence of states. States retain the right to join or not to join international treaties, of which one is the United Nations Charter.

Immediately after the UN was founded one of the most contentious issues of the organization was admission. Article 4 of the Charter determines the substantive and procedural law on admission. ${ }^{389}$ Paragraph 1 of Article 4 determining the substantive law and states that:

\footnotetext{
${ }^{385}$ The axis powers quite naturally were not part of the process of establishing the United Nations.

${ }^{386}$ United Nations Charter, Article 110, gives a special position to the permanent five by stating that: "the present Charter shall come into force upon the deposit of by the Republic of China, France, the Union of Soviet Socialist, the United Kingdom of Great Britain and Northern Ireland, and the United States of America, and by a majority of the other signatory states".

${ }^{387}$ See United Nations Charter, Article 108 and 109.

${ }^{388}$ Hans Kelsen, Membership in the United Nations, 46 Colum. L. Rev. 391 (1946), pg. 394.

${ }^{389}$ Admission of a State to the United Nations (Charter, Art. 4), Advisory Opinion: I.C.J. Reports 1948, p. 64.

Such a distinction on substantive and procedural aspects of admission was also made by the ICJ in the
} 
"Membership in the United Nations is open to all other peace-loving states which accept the obligations contained in the present Charter and, in the judgment of the Organization, are able and willing to carry out these obligations. "390

The Charter makes admission possible to "all other states", which implies that if an original member terminates its membership it cannot regain it back as admission is reserved for the category of non-original members. ${ }^{391}$ Such an option is available for the ones that have acquired membership through the admission process, which can unlimitedly use admission to regain membership. Though the wording may suggest so, in practice it would not be feasible that an original member state of the UN can never apply again through readmission. Paragraph 2 of Article 4 determining the procedural law states that:

"The admission of any such state to membership in the United Nations will be effected by a decision of the General Assembly upon the recommendation of the Security Council." 392

Though seemingly short and clear, Article 4 required two ICJ Advisory Opinions to clarify the substantive and procedural law on admission.

\subsection{SUBSTANTIVE LAW ON ADMISSION}

The members of the UN could not agree whether the conditions for admission enumerated in paragraph 1 of Article 4 are exhaustive or whether new conditions for membership can be introduced. A practice of introducing new conditions for membership on top of the ones enumerated was blocking admission of states. In order to address this issue the GA requested from the International Court of Justice an Advisory Opinion on the "Conditions of Admission of a State to the Membership in the United Nations" (Article 4 of the Charter). ${ }^{393}$

The Court held that a Member of the UN when voting in the Security Council and the General Assembly on admission juridically is to make its consent to admission based on conditions expressly provided in paragraph 1 and that if conditions for admission are fulfilled by an applicant it cannot subject its affirmative vote to the admission of other states together with that state. ${ }^{394}$ The Court did not define the meaning, the

advisory opinion which while being specific about paragraph 1 that it represents substantive law refers to paragraph 2 as the procedure whose character is indicated by the words "will be effected".

${ }^{390}$ United Nations Charter, Article 4, para. 1.

${ }^{391}$ Hans Kelsen, Membership in the United Nations, 46 Colum. L. Rev. 391 (1946), pg. 396.

${ }^{392}$ United Nations Charter, Article 4, para. 2. This was a major departure from the practice of the League of Nations which allowed admission if agreed by two-thirds majority of the Assembly and did not provide for any decision-making in the admission process for the Council. See Covenant of the League of Nations, Article 1 , para. 2.

${ }^{393}$ Admission of a State to the United Nations (Charter, Art.4), Advisory Opinion: I.C.J. Reports 1948, p. 57.

${ }^{394}$ Ibid., p. 65. 
scope or specify elements to be used for determining the enumerated conditions, as the request of the General Assembly did not ask for such a clarification. ${ }^{395}$

However, it stated that the conditions are an exhaustive enumeration neither guidance nor example) as they are not merely the necessary conditions, but conditions that suffice. ${ }^{396}$ This position is in line with the idea of having an organization of universal character with an open door policy.

The opposite would mean that conditions for admission are not exhaustive, are of political nature beyond the conditions of admission set out by the international organization, or are of other nature which eventually is detrimental to the success of the international organization and in opposition to the goals set out by the organization. The conditions (according to the Court) do not represent an indispensable minimum in a way that political consideration may be superimposed and prevent applicants that fulfill them to join the organization because the contrary would give Members unlimited and indefinite power of imposing new conditions, which would be inconsistent with Article $4 .^{397}$ Article 4 paragraph 1 of the Charter sets out five conditions for admission that an applicant in the judgment of the Organization (SC and the GA and its Members) must fulfill: 1 . be a State; 2 . be a peace loving one; 3 . accept the obligations of the Charter; 4 . be able to carry out these obligations and 5. the State should be willing to do so. ${ }^{398}$ The membership criteria are important as they also inform us about the aspirations of the organization. $^{399}$

With the first condition requiring that the applicant is a State, the admission process seems to create a higher requirement in comparison to some of the original members that were not states. The decision on admission is based on the fact whether a state is able and willing in the judgment of the United Nations to fulfill its obligations under the Charter. ${ }^{400}$

In comparison to the League of Nations this was also a great departure as the League allowed admission to "any self-governing State, Dominion or Colony not named in the Annex. ${ }^{401}$ Here, the threshold for acceding seems to be higher in compari-

${ }^{395}$ Ibid., p. 60.

${ }^{396}$ Ibid., p. 62. The Charter would have had a different wording of Article 4 if the intent of the authors of the Charter would have been to allow members to add additional conditions. See p. 63 of the Advisory Opinion.

${ }^{397}$ Ibid., p. 62-63.

${ }^{398}$ Ibid., p .62.

${ }^{399}$ Alison Duxbury, The Participation of States in International Organizations, the Role of Human Rights and Democracy, Cambridge University Press, 2011, pg. 5.

${ }^{400}$ Christian Hillgruber, The Admission of New States to the International Community, 9 Eur. J. Int. L. 491 (1998), pg. 499. The author states that the: "ability and willingness of the new state to respect international law constitute the central criteria for statehood in terms of international law”, pg. 503.

${ }^{401}$ The original members of the League of Nations Signatories of the Treaty of Peace were 27 states and 5 dominions of the British Empire: United States of America, Belgium, Bolivia, Brazil, British Empire (Canada, Australia, South Africa, New Zealand, India), China, Cuba, Ecuador, France, Greece, Guatemala, Haiti, Hedjaz, Honduras, Italy, Japan, Liberia, Nicaragua, Panama, Peru, Poland, Portugal, Romania, Serb-CroatSlovene State, Siam, Czecho-Slavakia, Uruguay. The opportunity to become an original Member was also given to the following 13 countries: Argentine Republic, Chili, Colombia, Denmark, Netherlands, Norway, Paraguay, Persia, Salvador, Spain, Sweden, Switzerland, and Venezuela. The remaining countries and other 
son to the WTO as well, as the UN does not admit any other Members but states. Clearly customs territories and international organizations are excluded.

The difficulty as stated above with this condition is that it is not always easy to determine statehood.

The second condition requires that the state wishing to join its Charter should be a peace loving state. This condition was incorporated in Article 4 of the Charter by the drafters with the intention of postponing the admission of the enemy states. This policy was successful for a time: Italy joined in 1955, Japan in 1956, and Germany in 1973. In fact even with the original members there was the issue of Argentina. Although Argentina declared war to Germany only six weeks before its final defeat and had not signed the United Nations Declaration (but in the whole power politics involving the USSR Republics and India), it was admitted as an original member of the United Nations. ${ }^{402} \mathrm{~A}$ number of states such as Spain, Sweden, Portugal, Ireland, Switzerland, Andorra, and Liechtenstein managed to remain officially neutral throughout the war though they supported the axis or the allied powers in different time periods. All these states joined the UN later through the admission process. Sweden joined in 1946, Spain, Ireland and Portugal in 1955, Liechtenstein in 1990, Andorra in 1993 and Switzerland in 2002. ${ }^{403}$

Whether a state is peace loving is very hard to determine as an objective criterion, and it is mostly dependent on the judgment of the Security Council and the General Assembly. As a legacy of the Second World War, such a specific reference does not exist for example in accession to the WTO, IMF, EU or OECD. According to Kelsen, the requirement of "peace loving" is superfluous as any state willing and able to carry out its Charter obligations fulfills that condition. ${ }^{404}$

The third and the fifth conditions, regarding the applicant state accepting and being willing to carry out Charter obligations, seems to go together. ${ }^{405}$ The issue of will is hard to determine since it is not an objective but rather a subjective criteria. However, if certain obligations are accepted by a state, for example by the willingness to adhere to a treaty such as the Charter, it is presumed that the state is also willing to carry them out. No Member would join or would be allowed to join an organization if it would not be willing to accept the obligations resulting from membership of such an organization. According to the Rules of Procedure of the General Assembly, and the ones of the Security Council, an applicant State submits to the Secretary General the application

subjects not belonging to any of the groups specified in the two annexes had the possibility to join through the admission process however did not have the right to become original members.

${ }^{402}$ Thomas D. Grant, Admission to the United Nations: Charter Article 4 and the Rise of Universal Organization, Martinus Nijhoff Publishers, 2009, pg. 25-27.

${ }^{403}$ See UN web page for specific dates of UN Member States joining the organization at: http://www.un.org/en/members/\#i, (visited May 2013).

${ }^{404}$ Hans Kelsen, Membership in the United Nations, 46 Colum. L. Rev. 391 (1946), pg. 393.

${ }^{405}$ Bengt Broms, The Doctrine of Equality of States as Applied in International Organizations, Vammala Kirjapaino, 1959, pg. 180. 
which contains a declaration that the Applicant State accepts the obligations of the Charter. ${ }^{406}$

The acceptance of the obligations and the willingness to carry them out may be considered implicit as the declaration is made in the form of a "formal instrument" that the State accepts the obligation of the Charter. ${ }^{407}$

With regard to the fourth condition for admission, namely the requirement that the state is able to carry out the obligations of the Charter, it should be noted that this issue was very much debated in the context of the admission of neutral states such as Austria and Switzerland as well as in the context of the admission of the microstates. The position of the drafters of the Charter was that no state with permanent neutrality is compatible with admission to the UN. ${ }^{408}$ However, Austria was admitted without any difficulties in 1995, as was Switzerland in 2002. Broms rightly is of the opinion that the admission of Austria which by analogy can now extend to the admission of Switzerland is a deviation from the principle of equality of states. ${ }^{409}$ Such a proposition is based on the assumption that the neutrality of Austria and Switzerland enshrined in their Constitutions may present an obstacle in carrying out some of their obligations of the Charter, such as the maintenance of international peace and security. The inequality is rather clear if one would compare these states with the rest of the UN members that do not have such an ability not to fulfill certain obligations deriving from the Charter. However, this seems to be a rigid approach. Though compatible with the wording of admission condition number four, the rejection of the admission of neutral states would have represented a greater deviation from the principle of equality of states. Neutrality is no different as a differentiating factor between states as are other factors such as size, population or ideology of communism or capitalism for that matter. The principle of equality of states is applicable exactly due to the existence differences between states, though their inability to carry out certain obligations deriving from the Charter due to their neutrality status remains as a fact.

Another situation deriving from these conditions is the issue of the so-called microstates that are accepted as states but their small size in terms of territory and population creates doubts regarding their statehood. This is the case among others with Andorra, Lichtenstein, Monaco, San Marino, Grenada, Bahamas Islands, Sao Tome and Principe. The issue with microstates is their (in)ability to use efficiently all their rights and more importantly fulfil all their obligations deriving from UN membership. This is particularly true in regard to representation and participation in all UN organs and

\footnotetext{
${ }^{406}$ See Rules of Procedure of the General Assembly, Rule 134, A/520/Rev.17 and Rules of Procedure of the Security Council, Rule 58, S/96/Rev.7.

${ }^{407}$ Benedetto Conforti and Carlo Focarelli, The Law and Practice of the United Nations, Fourth Revised Edition, Martinus Nijhoff Publishers, 2010, pg. 30; Bengt Broms, The Doctrine of Equality of States as Applied in International Organizations, Vammala Kirjapaino, 1959, pg. 180.

${ }^{408}$ See Hans Kelsen, The Law of the United Nations: A Critical Analysis of its Fundamental Problems, With Supplement, Stevens \& Sons Limited, 1951, pg. 94; Bengt Broms, The Doctrine of Equality of States as Applied in International Organizations, Vammala Kirjapaino, 1959, pg. 208.

${ }^{409}$ Bengt Broms, The Doctrine of Equality of States as Applied in International Organizations, Vammala Kirjapaino, 1959, pg. 213.
} 
bodies, and it is also true in regard to their financial contributions to the UN. Fortunately for the principle of equality of states, ideas about granting these states special forms of membership in the UN did not achieve sufficient support and they were granted full membership. ${ }^{410}$ While some states are really small and their capacities limited, not to allow them admission for that reason would have been a gross deviation from the principle of equality of states as it goes against the very essence of the principle of sovereign equality for all states in the UN Charter.

The second major issue dealt by the first ICJ Advisory opinion regarding the conditions for admission was the tendency of conditioning one or more admissions with the admission of other states, although each application should be reviewed individually. Linking applications makes admission not dependent on the fulfillment of the conditions by the applicant state alone, but also on the fulfillment of the condition by other applicant states. The Court held that each application for admission to the UN must be judged on its own merits, and the examination and the vote should be separate from considerations of other applicant states, because linking the decision to the application of another State would be incompatible with Article 4 and prevent judgment for each case in complete liberty. ${ }^{411}$

Without too much consideration for the Advisory Opinion, the US and the Soviet Union established a practice that if a country from one side of the cold war block was admitted then a country from the other side should be admitted as well, resulting in the so-called "horse trading and blackmail" in the Security Council. ${ }^{412}$ In such instances one can speak of the politics of admission and not about fulfilling criteria's for admission to the United Nations. This practice creates a situation where the law of the Charter is not enforced for each applicant in good faith according to the object and purpose of the Charter. It creates an inequality by which different states receive different treatment.

Conscious of the fact that the US and the USSR were using admissions in the pursuit of their individual goals, the General Assembly from 1948-1954 adopted every year a resolution addressed to the Security Council informing it of the general sentiment in the GA for universality. ${ }^{413}$ Such situations of power politics between the Great Powers created circumstances for at least two scenarios in clear deviation from the principle of equality of states. First, a state might fulfil the admission criteria and yet be rejected because of politics between two superpowers. In the second possible scenario, a state does not fulfill admission criteria, yet it is allowed to join. There is a clear deviation from the principle of equality of states in both situations. In the first one, a state upon condition of fulfilling the criteria for admission is perfectly entitled to join the United Nations without having ideological opposition between the great powers blocking it. In

${ }^{410}$ See Michael M. Gunter, What Happened to the United Nations Ministate Problem, 71 Am. J. Int’l. L. 110 (1977), pg. 110-124.

${ }^{411}$ Admission of a State to the United Nations (Charter, Art.4), Advisory Opinion: I.C.J. Reports 1948, p. 65.

${ }^{412}$ Niels Blokker, International Organizations and Their Members, 1 Int'l. Org. L. Rev. 139 (2004), pg. 145.

${ }^{413}$ Marie-Claude Smouts, 'The General Assembly: Grandeur and Decadence' in Paul Taylor and A. J. R. Groom, Editors, The United Nations at the Millennium: The Principal Organs, Continuum International Publishing Group, 2003, pg. 28. 
the second situation, a state does not fulfill the criteria but gets an entry ticket as part of a package deal. As Blokker correctly noted, the "Cold War Condition", requiring a country from each side to be admitted if admission was to take place is not part of the 5 condition list. ${ }^{414}$ This seems to represent condition 6 on top of the previous 5 enumerated ones.

Another particularly interesting case is the admission of R. Macedonia to the United Nations and the resolution of the so-called "name dispute" between R. Macedonia and Greece as part of the admission criteria. According to the Security Council Resolution 817 of 7 April 1993, the Security Council, having examined the application for membership to the UN, notes that "the applicant fulfils the criteria for membership in the United Nations laid down in Article 4 of the Charter" ${ }^{415}$ In the same resolution, the Security Council also recommended the General Assembly to admit "the State" (without the name) to the UN under the provisionally referred name "the Former Yugoslav Republic of Macedonia” for all purposes within the United Nations pending the settlement of the dispute. ${ }^{416}$ This case also seems to be in deviation from the principle of equality of states, having in mind the fact that the SC considers that all the conditions for admission of Article 4 are fulfilled, and yet a bilateral dispute affects the membership in regard to an issue as important as the name of the country. ${ }^{417}$

\subsection{PROCEDURAL LAW ON ADMISSION}

Kelsen early on stated that the wording of Article 4 is misleading as even a state that objectively fulfills all the conditions has no automatic right to be admitted as this should be judged by the Organization, namely, the discretion of the Security Council and the General Assembly. ${ }^{418}$ This statement gave an insight into the (ab)use of these discretionary powers and inequality in treatment between applicants.

The procedure for admission starts by the submission of an application to the Secretary General, who sends a copy to the Security Council and the General Assembly. And if the Security Council recommends membership, then the application is forwarded to the General Assembly for a decision. ${ }^{419}$ As simple as it may sound, the procedural law on admission also required further clarification from ICJ. Namely, there were conflicting positions between states whether the General Assembly can, without a

\footnotetext{
${ }^{414}$ Niels Blokker, International Organizations and Their Members, 1 Int'l. Org. L. Rev. 139 (2004), pg. 145.

${ }^{415}$ United Nations Security Council Resolution, S/RES/817 (1993).

${ }^{416}$ United Nations Security Council Resolution, S/RES/817 (1993), p.2.

${ }^{417}$ The name dispute consequently continued to be an issue for admission in other international organizations, such as NATO in 2008, and in the start of negotiations for accession to the European Union as well. The blockade of admission to NATO was brought to the International Court of Justice which rendered its decision in December 2011. The Court held that Greece by objecting the admission of R. Macedonia to NATO breached its obligations under the Interim Accord not to pose an obstacle to membership in international organizations for the FYR of Macedonia. See Application of the Interim Accord of 13 September 1995 (the former Yugoslav Republic of Macedonia v. Greece)- Judgment of 5 December 2011, p. 48.

${ }^{418}$ Hans Kelsen, Membership in the United Nations, 46 Colum. L. Rev. 391 (1946), pg. 393.

${ }^{419}$ See Rules of Procedure of the General Assembly, Rules 134-136; Rules of Procedure of the Security Council, Rules 58-60.
} 
recommendation of the Security Council, decide on admission cases. Such a position was a result of admissions being blocked by a Security Council unwilling to give recommendation primarily due to Cold War reasons between the Soviet Union and the US. The GA being more in favor of admissions of states and achieving universality was looking more in favor of an interpretation that would allow for admissions to take place even without recommendations of the Security Council. Again, in order to overcome the deadlock, the issue was addressed to the ICJ where the so called second Advisory Opinion regarding admission was rendered.

The Court was asked to give an Advisory Opinion on the following:

"can the admission of a State to membership in the United Nations, pursuant to Article 4, paragraph 2, of the Charter, be effected by a decision of the General Assembly when the Security Council has made no recommendation for admission by reason of the candidate failing to obtain the requisite majority or of the negative vote of a permanent Member upon a resolution so to recommend?". 420

The Court by twelve votes to two held that admission to membership in the UN:

"cannot be effected by a decision of the General Assembly when the Security Council has made no recommendation for admission by reason of the candidate failing to obtain the requisite majority or of the negative vote of a permanent Member upon a resolution so to recommend". ${ }^{421}$

There is no doubt for the Court that two things are required for an admission to take effect: a Security Council "recommendation" and a General Assembly “decision”. ${ }^{422}$ The Advisory Opinion came as the result of a power struggle and the futile efforts of the General Assembly to establish a position of supremacy in the admission process in comparison to the Security Council. The idea was that the SC, upon receiving an application, has to give a recommendation (positive or a negative one) but it was up to the GA to be the main decision maker. The Court disagreed. To hold that in absence of a recommendation from the SC, the GA can admit a State to membership would mean to deprive the SC of an important power vested to it by the Charter. ${ }^{423}$ According to the Rules of Procedure of the SC and of the GA, they decide separately if the applicant is

${ }^{420}$ Competence of Assembly regarding admission to the United Nations, Advisory Opinion: I.C.J. Reports 1950 , p. 5.

${ }^{421}$ Ibid., p. 10

${ }^{422}$ Ibid., p. 7-8.

${ }^{423}$ Competence of Assembly regarding admission to the United Nations, Advisory Opinion: I.C.J. Reports 1950, p. 9. Also see Kelsen's interpretation that according to the wording of the Charter, the Security Council may give a favorable or unfavorable recommendation and then the Assembly decides on its own. However, he continues, the drafters probably did not assign a subordinate role for the SC and therefore the wording of Article 4 should have stated that "upon favorable recommendation of the SC" the GA's concurrent decision is required for an admission to take place. This implies that not without a recommendation and not without a favorable recommendation is admission possible. See: Hans Kelsen, The Law of the United Nations: A Critical Analysis of its Fundamental Problems, With Supplement, Stevens \& Sons Limited, 1951, pg. 61-64. 
fulfilling the conditions of being: a peace-loving State, able to carry out obligations of the Charter and is willing to do so. ${ }^{424}$ The SC decides on the admission of new Members to the United Nations by an affirmative vote of nine, including the concurring votes of the permanent members. ${ }^{425}$ The General Assembly decides with a majority of two-thirds of Members present and voting. ${ }^{426}$ By order of things, the SC is the first organ to pass such a judgment and only if there is a recommendation for membership does the GA consider the application.

In his dissenting opinion Judge Alvarez trying to shift the decision-making powers to the GA, holds that the General Assembly is in an active role. While it is true that the Security Council should make the recommendation, it is the GA that effects an admission. ${ }^{427}$ He continues by criticizing the exercise of the veto power beyond the maintenance of international peace and security (such as in admission cases) as it "could frustrate the will of all the other Members of that Council and of the General Assembly and...that would reduce the U.N.O to impotence."428 Pressed into extremes one state alone with the veto power can stop the admission of a state in the UN even if hypothetically literally all other 192 out of the 193 current Members of the UN may be in favor. This 1 veto power holder multiplied by 5 raises the probability of such possible scenario. For that matter, the General Assembly called a number of times on permanent members of the SC to refrain from using the veto in admission applications. ${ }^{429}$ In the period between 1946 and 1955 the USSR used its veto as many as 47 times to prevent admission of applicant countries favored by the West. ${ }^{430}$ In other instances efforts were made not to use the veto power and yet to block admission. For example, instead of reviewing the application for membership of Albania to the United Nations, the Security Council postponed the decision for 1946 and then, again postponed it for 1947. Thus it was not clear whether such a decision was in fact a rejection of the application resulting with negative recommendation. This raised the issue of whether such a postponing is a rejection of the application for membership, which would thus constitute a nonprocedural decision? The motion was placed to a vote which resulted in Member States

\footnotetext{
${ }^{424}$ Rules of Procedure of the Security Council, Rule 60; Rules of Procedure of the General Assembly, Rule 136

${ }^{425}$ United Nations Charter, Article 27, para. 2, para. 3.

${ }^{426}$ United Nations Charter, Article 18, para. 2.

${ }^{427}$ Competence of Assembly regarding admission to the United Nations, Advisory Opinion: I.C.J. Reports 1950, Dissenting Opinion of M. Alvarez, p. 19.

${ }^{428}$ Ibid., p. 20. The dissenting opinion of Judge Alvarez seems to explain somewhat more clearly the Advisory Opinions that the conditions are exhaustive, that admission applications should be judged individually for each state and not conditioned upon the admission of another state. He states that in the spirit of the Charter and the universal role of the United Nations "all members of the international community which fulfil the conditions laid down in Article 4 should be admitted to the United Nations; these states have right to be admitted.

${ }^{429}$ See for example GA Resolutions on Admission of New Members, A/RES/296 B (IV) of 1949, A/RES/296 K (IV) of 1949.

${ }^{430}$ Marie-Claude Smouts, 'The General Assembly: Grandeur and Decadence' in Paul Taylor and A. J. R. Groom, Editors, The United Nations at the Millennium: The Principal Organs, Continuum International Publishing Group, 2003, pg. 28.
} 
having different positions about whether the issue is substantive or procedural, as the first enabled the use of the veto powers and the second did not. ${ }^{431}$

These power games caused a deadlock in the admission process of the United Nations and were a major obstacle in achieving universality. The veto power in the Security Council to block membership applications was frequently used in the early years of the organization, few times since 1962 and never as of $1977 .{ }^{432}$ The overwhelming majority of the membership applications to the UN as of 1962 have been adopted either unanimously or by consensus in the Security Council and the General Assembly. ${ }^{433} \mathrm{~A}$ major breakthrough in the admission process was finally made in 1955 when, after a long diplomatic struggle, 16 admissions were accepted thus making a decisive step forward to achieving universality.

\section{ACQUISITION OF MEMBERSHIP IN THE UNITED NATIONS AND THE PRINCIPLE OF EQUALITY OF STATES}

The application of the principle of equality of states in acquisition of membership to the UN has a number of implications. Participation in the preparatory work and the opportunity to influence the content of the Charter was primarily limited only to the main Big Powers and especially to the US, USSR and UK. Participation in the negotiations was not a possibility for many states due to the division that existed in the world at the time. In addition, participation at the San Francisco conference dependent on the will of the Big Powers who decided which sates will receive invitations to become part of the negotiations and at the same time become eligible for original membership. A number of entities that were yet to become independent states, such as India, the Philippines, Belarus and Ukraine were granted access to the negotiations and original membership. In comparison to existing states as well as other similar non-states entities not having such an opportunity this represented a clear deviation from the principle of equality of states. With regard to admission to the UN after its establishment, the criteria for admission of Article 4 seem to be in line with the principle of equality of states. However, the application of the admission criteria in practice has resulted with unequal treatment between states in a number of times. Such situations represented deviations from the principle of equality of states. The process where the two superpowers of the world did use admission for their individual gains, obviously disregarding the object and purpose of the UN Charter and not interpreting admission conditions in good faith has resulted in inequality between states. Moreover, the decision-making in regard to admission represents a deviation from the principle of equality of states as it differentiates between

${ }^{431}$ While four permanent members: China, France, the UK and the USSR considered this to be a substantive and not a procedural issue the US and 4 other non permanent Members considered this to be a procedural issue and two Members abstained from voting. See, Aleksandar W. Rudzinski, The So-Called Double Veto, 45 Am. J. Int'l. L. 443 (1951), pg. 451-452.

${ }^{432}$ Henry G. Schermers \& Niels M. Blokker, International Institutional Law, Fifth Revised Edition, Martinus Nijhoff Publishers, 2011, pg. 83.

${ }^{433}$ Ibid. 
the permanent five, the non-permanent members of the SC and the General Assembly. Namely, the permanent five can individually block any admission while this is not an opportunity for the other non-permanent members. Further on, the 10 non-permanent members can also block any admission with or without any permanent member concurring on the vote placing in a better position in comparison to the GA Members. Finally, the members of the SC have a dual vote, as they cast their votes as members of the SC and as members of the GA on the same matter, a voting right not extended to the GA members.

\section{DECISION-MAKING}

The United Nations Charter determines as the principal organs of the United Nations: the General Assembly, the Security Council, the Economic and Social Council, the Trusteeship Council, the International Court of Justice and a Secretariat”. ${ }^{434}$ Their composition, functions and voting powers constitute the most substantial (non)application of the principle of equality of states. From these organs the most important are the General Assembly and the Security Council and consequently require greater attention. ${ }^{435}$ The ICJ and the Secretariat will be also addressed in light of the application of the principle of equality of states.

Before going any further, it is important to make an important distinction that the SC, the GA and the ECOSOC are made up of individuals representing states and casting votes on behalf of their state, while the ICJ and the Secretariat are made up of individuals who take office as private persons, do not represent states and are not bound by the will of any state. ${ }^{436}$ This is a very significant distinction, which is extremely important to the application of the principle of equality of states because the Organs (composed of state representatives) differ in the application of the principle of equality of states in terms of equality of representation of states.

\section{THE SECURITY COUNCIL}

The Security Council (SC) of the United Nations is without any doubt the most important organ of the UN. In "discharging" its powers and functions, the Security Council is obligated by the Charter to act in accordance with the Purposes and Principles of the UN which, as stated above, include Article 1 on the "friendly relations of nations based on equal rights of peoples" and Article 2.1 on "sovereign equality of its mem-

\footnotetext{
${ }^{434}$ United Nations Charter, Article 7.

${ }^{435}$ The ECOSOC which together with the Trusteeship Council is under the authority of the General Assembly and thus will be covered in the section dealing with the General Assembly. Moreover, the Trusteeship Council after the independence of Palau, the last remaining UN trust territory in October 1994, suspended operation on 1 November 1994. See the Trusteeship Council web page at http://www.un.org/en/mainbodies/trusteeship/, (visited March 2013).

${ }^{436}$ Benedetto Conforti and Carlo Focarelli, The Law and Practice of the United Nations, Fourth Revised Edition, Martinus Nijhoff Publishers, 2010, pg. 9.
} 
bers. ${ }^{437}$ Thus, the Organ which (as it will be seen in the next sections) represents clearly the greatest single deviation from the principle of equality of states in the UN (and arguably beyond) is paradoxically supposed to act in accordance with the "Principles and Purposes of the Charter", which strongly relate to the principle of equality of states. The fact that the Security Council due to the veto power and limited membership is not in line with the principle of equality of states is reiterated time and again in major publications of international law. ${ }^{438}$

The (non)-application of the principle of equality of states in the Security Council is related to the fact that the SC is a non-plenary organ with limited membership providing for a two-level composition of members (permanent and non-permanent members). In addition, the powers and functions vested in the SC for an extremely broad range of issues in comparison to the General Assembly (which is the plenary Organ of the UN) also represents a deviation from the principle of equality of states.

The veto powers and the limited membership of the Security Council represent the gravest inequality of states. This may rightly be named as "legalized hegemony". 439

\subsection{LIMITED MEMBERSHIP RESULTING IN LIMITED EQUALITY}

The Security Council is composed of five permanent members: the US, Russia, UK, France and China, and ten non-permanent members elected by the General Assembly for a term of two years. ${ }^{440}$ Each of the members of the Security Council, in line with the principle of equality of states, has one representative and one vote. ${ }^{441}$ However, each of the five permanent members has a veto power while the non-permanent members do not have a veto power. ${ }^{442}$ The permanent members are a static group whose membership is always known and never changes. On the other hand, the non-permanent members are rather dynamic and are unknown until elected by the General Assembly. The permanent five even before becoming officially the permanent five, had a more privileged position as they drafted the Charter (especially the US, UK, and USSR). They also had the opportunity to become original members, and to sign the Charter first as without them it would not come into force. While their position from the outset has remained the same,

\footnotetext{
${ }^{437}$ United Nations Charter, Article 24, para. 2.

${ }^{438}$ For example see Jennings and Watts stating that "the Security Council departed from the principle of equality of states”, in Jennings and Watts, Editors, Oppenheim's International Law, Ninth Edition, Volume I, Peace: Introduction and Part I, Published by Addison Wesley Longman, 1997, pg. 339-340.

${ }^{439}$ Gerry Simpson, Great Powers and Outlaw States: Unequal Sovereigns in the International Legal Order, Cambridge University Press, 2004, pg. 10.

${ }^{440}$ United Nations Charter, Article 23.

${ }^{441}$ United Nations Charter, Article 23, para. 3, Article 27, para. 1.

${ }^{442}$ The veto power of the permanent five has not remained a formal right without application as it was used in the practice of the work of the Security Council by each of the permanent five. In between 1946-1997 the veto power was used 116 times by the Soviet Union (75 of which were in the first decade of the UN when it was dominated by the West), by the US 72 times (34 of which were during 1976-1985 when the UN was dominated by the socialist and non-aligned members), by UK 30 times, by France 18 times and least by China using its veto powers only 4 times, see Nigel D. White, 'Decision-making' in Jan Klabbers and Åsa Wallendahl, Editors, Research Handbook on the Law of International Organizations, Edward Elgar Publishing Limited, 2011, pg. 241.
} 
the number of non-permanent members increased from the original six to ten, thus increasing the number of members from eleven to fifteen. ${ }^{443}$ As a result, further amendments to the Charter were made to increase the number of votes required for the Security Council to pass decisions and to amend the Charter in light of the enlarged representation of the Security Council. ${ }^{444}$ These amendments, while not sufficient, have contributed to improving the application of the principle of equality of states by increasing state representation and reducing inequality to a certain degree. In the election process of the non-permanent members, the General Assembly has in mind the contribution of a Member to the UN and equitable geographical distribution. ${ }^{445}$ In order to achieve equitable geographical distribution, there is an arrangement that from the seats for non-permanent members of the Security Council, five of them will be assigned to the Afro-Asian states, two to the Latin American ones and the remaining three for European and remaining states. ${ }^{446}$ Some consider that geographical representation may rectify the breach of sovereign equality. ${ }^{447}$ This perhaps is too strong of a statement, because geographical representation cannot rectify the deviation from the principle of equality of states. However, it can help ameliorate the inequalities seen in the permanent composition of the SC by assigning specific regions of the world guaranteed representation. As stated in the previous chapter, there is a right to nominate (as a group of states) a representative and there is a right to be represented (as a state). The state representing itself is in a better position than the states it represents. Furthermore, there is no formal legal obligation for a state to act in the interest of the states it represents.

Except for this division between the two main categories of members of the SC, there is inequality even within each group of states. In terms of the permanent members, they have never had equal or similar powers, as even between them there was no equality of status. If one could favor inequality between states due to the fact that some states are Great Powers and the rest are not, this was not the case with France and China (also the UK to a certain extent) in comparison to the power of the US and the USSR. Both France and China were under occupation and devastated by the war and few could have argued that at the time they reached the status of the Great Powers, they had the capacity for that. In these lines, Claude considers the US and the USSR as the real super powers, while on the position of the UK, France and China, he states:

\footnotetext{
${ }^{443}$ Article 23 was amended on 17 December 1963 and came into force on 31 August 1965. At the same time amendments to Articles 27 and 61 of the Charter were made as well. Article 23 determines that the Security Council will be composed of fifteen Members out of which the permanent five will be: China, France, Russia, UK, USA.

${ }^{444}$ The amendment of Article 27 foresees decisions on procedural matters by an affirmative vote of nine members and other matters by affirmative vote of nine members including the concurring votes of the permanent five. As the result of the increase in numbers of states in the Security Council Article 109 of the Charter requiring nine members of the Security Council (before it was nine) was also amended.

${ }^{445}$ United Nations Charter, Article 23, para. 1 and 2.

${ }^{446}$ Malcolm N, Shaw, International Law, Sixth Edition, Cambridge University Press, 2008, pg. 39-40.

${ }^{447}$ Athena Debbie Efraim, Sovereign (In)equality in International Organizations, Martinus Nijhoff, 2000, pg. 122
} 
"Great Britain ranks third. It has long been the foremost nation of the world, but its power seems to be definitely on the wane. The future of Great Britain may depend largely on its empire, but it can hardly expect to do better than hold its own; it cannot outstrip the United States and Russia. Into the third category fall France and China. It is rather difficult to understand how they came to be classed as members of the Big 5 at all. France is today extremely weak, by the standards of the United States, Great Britain, and Russia, and by comparison with its own former glory. Its chief claim to the position of a major power lies in its history, but today it is decadent, economically impotent, and stigmatized by its quick and decisive defeat at the hands of Germany. There may be a resurgence of French power, but I frankly do not expect it. China's position as a world power lies in its possibilities for the future certainly not in its past or present. When we class China as a major power, we mean that we expect it to become a world power." 448

Simpson makes a similar statement by noting that it is not that the membership of the permanent five in the SC is an anachronism of today, but it has always been an anachronism, as even in 1945 two of the Great Powers actually were not such powers to deserve such a status. ${ }^{449}$ China's participation as a Great Power was favored by the US due to its interests in the Pacific. However, this was opposed by the UK and the USSR which did not consider it to be a Great Power worthy of the position. Similar sentiments existed by the US in regard to France which was not considered a Great Power though its position in the Great Five was favored by the UK desiring a greater presence of European states. Another fact is that the enemy states such as Germany, Japan and to a lesser extent Italy were also Great Powers of the time and Great Powers of the Council of the League of Nations. ${ }^{40}$

The omission of the enemy nations caused an imbalance in the formation of the UN, as it would have been incomprehensible to leave aside Great Powers such as Germany and to an extent Japan and Italy had the UN been established in peace time, and not after the worst war ever seen by mankind, and for which the Axis Powers were responsible. For example, Japan and Germany today are the second and the third largest contributors of the UN after the United States. ${ }^{451}$

With regard to non-permanent members of the SC, since 1965 non-permanent member seats are distributed in the following way: African and Asian states (5 seats), Eastern European states (1 seat), Latin American and Caribbean states (2 seats), West-

${ }^{448}$ Inis L. Claude, Jr., A Scholar's Beginnings: A Study of the San Francisco Charter, 40 Va. J. Int'l. L. 311 (1999-2000), pg. 322-323.

${ }^{449}$ Gerry Simpson, The Great Powers, Sovereign Equality and the Making of the United Nations Charter, 21 Aust. YBIL 133 (2000), pg. 141.

${ }^{450}$ Italy and Japan were original members of the League of Nations and permanent members of the Council. Germany joined in 1926, was a Great Power and a permanent member of the Council. Germany and Japan withdrew from the League of Nations in 1933, Italy in 1937.

${ }^{451}$ See Assessment of Member State's contributions to the United Nations regular budget for the year 2011, United Nations Secretariat Document, ST/ADM/SER.B/824, 28 December 2010, pg. 2-7. 
ern Europe and other states (2 seats). ${ }^{452}$ An obvious deviation from the principle of equality of states in this distribution, among others, is seen in the allocation of the seats to European states in the Security Council in the form of 2 permanent (UK and France) and 3 non-permanent states. However, even amongst the potential non-permanent members of the Security Council there is no equality between states. If one includes the states that start their two year term beginning in 1 January 2012, there are actually seventy-two UN members that have never been members of the Security Council. ${ }^{453}$ From the remaining states, some with the most frequent representation were elected up to ten times though the greatest majority was elected once or twice as members of the Security Council. For example Brazil and Japan were elected ten times, Argentina eight, Columbia, India and Pakistan seven, Italy six times and a number of states such as Belgium, Germany, Netherlands, Panama and Poland five times. From the remaining, thirteen states ${ }^{454}$ have been elected four times to be non-permanent members of the Security Council, another twenty states have been elected three times, ${ }^{455}$ thirty-one states were elected two times, ${ }^{456}$ and not surprisingly the biggest group is the forty-two states who were represented only ones ${ }^{457}$ in the Security Council. ${ }^{458}$

This representation can be better illustrated in the following chart:

${ }^{452}$ Henry G. Schermers \& Niels M. Blokker, International Institutional Law, Fifth Revised Edition, Martinus Nijhoff Publishers, 2011, pg. 227, in ECOSOC: Africa has 14 members, Asia 11, Latin America and Caribbean 10, Western European and other states 13 and Eastern European states 6.

${ }^{453}$ The following members have never been elected members of the Security Council: Afghanistan, Albania, Andorra, Antigua and Barbuda, Armenia, Bahamas, Barbados, Belize, Bhutan, Brunei Darussalam, Cambodia, Central African Republic, Chad, Comoros, Cyprus, Democratic People’s Republic of Korea, Dominica, Dominican Republic, El Salvador, Equatorial Guinea, Eritrea, Estonia, Fiji, Georgia, Grenada, Haiti, Iceland, Israel, Kazakhstan, Kiribati, Kyrgyzstan, Lao People’s Democratic Republic, Latvia, Lesotho, Liechtenstein, Lithuania, Luxembourg, Malawi, Maldives, Marshall Islands, Micronesia, Monaco, Mongolia, Montenegro, Mozambique, Myanmar, Nauru, Palau, Papua New Guinea, Republic of Moldova, Saint Kitts and Nevis, Saint Lucia, Saint Vincent and the Grenadines, Samoa, San Marino, Sao Tome and Principe, Saudi Arabia, Serbia, Seychelles, Solomon Islands, South Sudan, Suriname, Swaziland, Switzerland, Tajikistan, the Former Yugoslav Republic of Macedonia, Timor-Leste, Tonga, Turkmenistan, Tuvalu, Uzbekistan, Vanuatu. For the full list of countries never to have been elected Security Council Members see UN web site at: http://www.un.org/sc/list_eng6.asp, (visited November 2011).

${ }^{454}$ The following States were elected four times non permanent members of the Security Council: Australia, Chile, Denmark, Egypt, Mexico, Norway, Peru, Philippines, Romania, Spain, Turkey, Venezuela and Yugoslavia;

${ }^{455}$ The following States were three times elected non permanent members of the Security Council: Algeria, Austria, Bulgaria, Costa Rica, Cuba, Ecuador, Gabon, Ghana, Indonesia, Irelands, Malaysia, Morocco, New Zealand, Portugal, Sweden, Syrian Arab Republic, Tunisia, Uganda, Ukraine, Zambia,

${ }^{456}$ The following States were two times elected non permanent members of the Security Council: Bangladesh, Benin, Bolivia, Burkina Faso, Cameroon, Canada, Congo, Cote d'lvoire, Czechoslovakia, D.R. of the Congo, Ethiopia, Finland, Greece, Guinea, Guyana, Hungary, Iraq, Jamaica, Jordan, Kenya, Lebanon, Libyan Arab Jamahiriya, Mali, Mauritius, Nepal, Nicaragua, Senegal, South Africa, Togo, United Republic of Tanzania, Zimbabwe.

${ }^{457}$ The following States were only once elected non permanent members of the Security Council: Angola, Azerbaijan, Bahrain, Belarus, Bosnia and Herzegovina, Botswana, Burundi, Cape Verde, Croatia, Czech Republic, Djibouti, Gambia, Guatemala, Guinea-Bissau, Honduras, Iran, Kuwait, Liberia, Madagascar, Mauritania, Namibia, Niger, Nigeria, Oman, Paraguay, Qatar, Republic of Korea, Rwanda, Sierra Leone, Singapore, Slovakia, Slovenia, Somalia, Sri Lanka, Sudan, Thailand, Trinidad and Tobago, United Arab Emirates, United Arab Republic, Uruguay, Vietnam, Yemen.

${ }^{458}$ Estimates based on the information on the members of the Security Council available from the UN web site at: http://www.un.org/sc/list_eng5.asp, (visited November 2011). 
Chart 5: The representation of UN Members in the Security Council as non-permanent members:

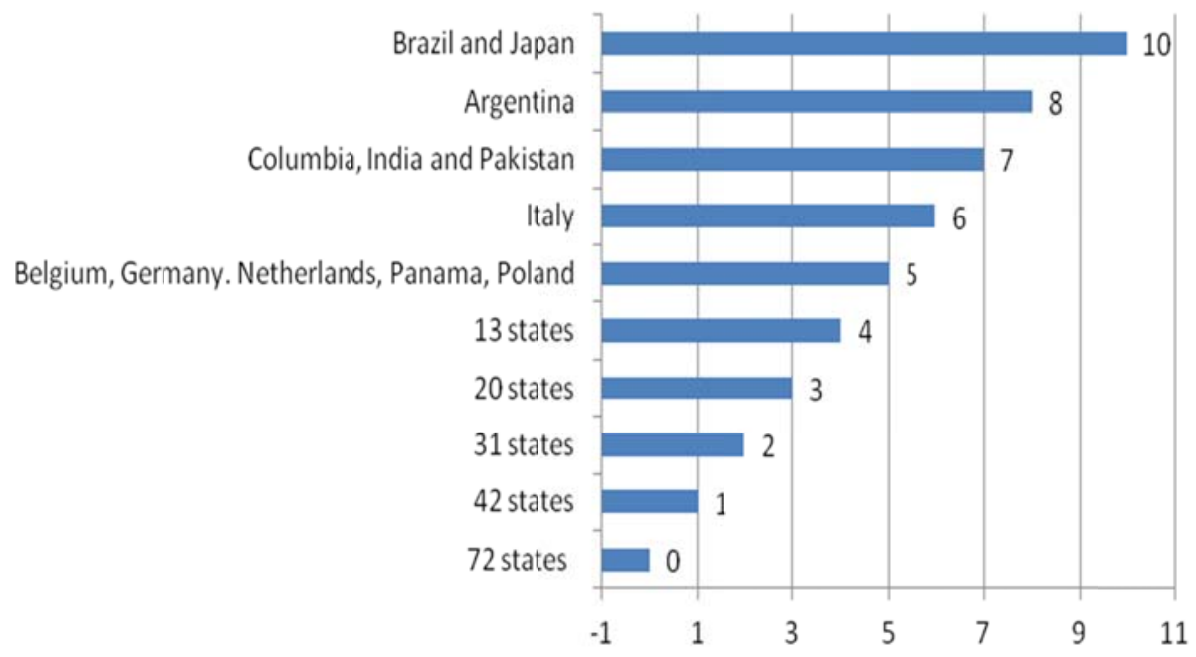

To make the deviation from the principle of equality of states even more severe, Ukraine was a member of the SC twice in 1948-1949 and 1984-1985, and Belarus once in 1974-1975, during the time they were Republics of the Soviet Union, and not states. With their legal status they should have never joined the UN, as it was only open to states. Ukraine and Belarus not only joined the UN as original members, but they were also elected as members of the SC. In relation to other members of the UN, and as mentioned in regard to the 72 member states that have never been elected SC members this is a severe deviation from the principle of equality of states.

As one can roughly observe even between major non-permanent member powers, there is not much equality in representation as non-permanent members. An obvious example for comparison is the difference between Brazil and Japan on the one hand and Germany on the other in the proportion of two to one. These three states as well as India, Nigeria and others have expressed ambitions to join the Security Council as permanent members, though their efforts so far have been unsuccessful. In Europe, Germany has been one of the states pursuing such an ambition. ${ }^{459}$ With time this ambition may change as "Germany's long-term goal in the course of a complete overhaul of the UN Security Council is a joint seat for the EU". ${ }^{460}$ Latin America and Africa remain without permanent representation in the SC and they also have serious candidates to offer in Brazil and Nigeria.

Besides the permanent and non-permanent members, the Charter allows for nonmembers of the Security Council (and even non-members of the UN) to participate in its

\footnotetext{
${ }^{459}$ For example see "German Hopes for UN Security Council Seat Dampened”, Deutsche Welle, 20 August, 2004, at: http://www.dw-world.de/dw/article/0,,1302199,00.html, (visited March 2013).

${ }^{460}$ German Federal Foreign Service: Germany in the UN Security Council. UN Security Council Reform is one of the five priorities of Germany during its 2011-2012 membership in the Security Council. Available at: http://www.auswaertiges-amt.de, (visited March 2013).
} 
sessions though without the right to vote. Such a right is given by the Charter in discussions on any question if the SC considers that a Member's interests are to be "specially affected". ${ }^{461}$ The SC may invite at the UN SC any UN Member, or any other state non UN Member, if it is a party to a dispute which is under consideration by the SC. ${ }^{462}$

\subsection{FUNCTIONS AND POWERS}

The most important function of the Security Council is its primary responsibility in maintaining international peace and security. ${ }^{463}$ In comparison to the GA, the decisions of the Security Council are binding as UN Members agree to accept and carry them out. ${ }^{464}$ Decisions on procedural matters are made by an affirmative vote of nine (formerly seven). On all other matters (non-procedural) are made with an affirmative vote of nine members (formerly seven) but also including the concurring votes of the permanent five. ${ }^{465} \mathrm{~A}$ minor compromise in reducing the powers of the permanent members of the SC was made between the Great Powers and the remaining states with the fact that if a permanent member is a party to a dispute, it will not have the veto power as it will abstain from voting under Chapter VI but not under Chapter VII. ${ }^{466}$

From Article 27 of the Charter one may clearly see the distinction between procedural and non-procedural issues in regard to voting. On procedural issues the permanent five do not have a veto power, though this has not always been an easy issue to determine whether an issue is procedural or not, thus amounting to a so-called double veto. ${ }^{467}$ The double veto is present when the Security Council decides whether an issue is a procedural matter or not in a decision-making process. Therefore, there is a double veto as it first applies the veto power to determine whether the issue is procedural, and second in deciding on the issue itself. ${ }^{468}$

The double veto creates a double deviation from the principle of equality of states because non-permanent states of the SC are dominated by the permanent five not only in non-procedural but also in procedural matters. ${ }^{469}$ One may add that there is another layer of deviation from the principle of equality as this privileged position of the perma-

\footnotetext{
${ }^{461}$ United Nations Charter, Article 31.

${ }^{462}$ United Nations Charter, Article 32.

${ }^{463}$ United Nations Charter, Article 24, para. 1. According to paragraph 2 of Article 24, the powers for the SC in discharging these duties are laid down in Chapter VI on Pacific Settlement of Disputes, Chapter VII regarding Threats to Peace, Breaches of Peace and Acts of Aggression, Chapter VIII on Regional Arrangements and Chapter XII on the International Trusteeship System.

${ }^{464}$ United Nations Charter, Article 25.

${ }^{465}$ United Nations Charter, Article 27, para. 2 and 3.

${ }^{466}$ United Nations Charter, Article 27, para. 3. Also see Frederic L. Kirgis, Jr., The Security Council's First Fifty Years, 89 Am. J. Int'l. L. 506 (1995), pg. 507.

${ }^{467}$ See, Aleksandar W. Rudzinski, The So-Called Double Veto, 45 Am. J. Int'l. L. 443 (1951).

${ }^{468}$ See Benedetto Conforti and Carlo Focarelli, The Law and Practice of the United Nations, Fourth Revised Edition, Martinus Nijhoff Publishers, 2010, pg. 81-88.

${ }^{469}$ Athena Debbie Efraim, Sovereign (In)equality in International Organizations, Martinus Nijhoff, 2000, pg. 138.
} 
nent five is not only in relation to the non-permanent members of the SC but also in regard to the other UN members not represented in the SC.

As the Security Council is not applying unanimity in its decision-making processes, one may state that this represents a deviation from the principle of equality of states in its decision-making. ${ }^{470}$ However, the deviation from the principle of equality of states is not related to the unanimity or for that matter, majority decision-making processes. The deviation from the principle of equality of states has to do with the inequality in representation and voting power between UN members in general, and between the permanent and non permanent members of the Security Council in particular. The fact that a member state has veto powers is not a deviation from the principle of equality of states per se. The fact that some and not all member states have equal veto powers represents a deviation from the principle of equality of states. Stated differently, the required unanimity of the permanent five only, and not of all the members equally, represents a deviation from the principle of equality of states. The privileged position of the SC's permanent members can be seen in the Chapter VII with regard to use of force and the need for their concurring votes in the collective security system, in the admission of new members, suspension and expulsion of members, the Secretary General's appointment, and decisions on amending the Charter.

Some of their privileged powers extend to the ICJ as well, in the admission of nonUN-members to the Statute of International Court of Justice or adopting measures to enforce ICJ decisions. ${ }^{471}$ In the election of ICJ Judges the permanent members of the SC do not have a veto power, which creates a more equal position with the non-permanent members. ${ }^{472}$ The SC permanent members have additional rights beyond UN, (for example in the ICC), in comparison with the non-permanent members of the SC, and all the other members of the UN as well, creating further inequality. ${ }^{473}$

In contrast to the GA, the SC is organized to function continuously with representatives of all SC members represented at all times. ${ }^{474}$

The deviation from the principle of equality of states in the Security Council can be clearly seen. Regardless of this fact, the Security Council is considered to be the most important Organ dealing with international peace and security. According to Simpson, it is possible to state that the "Security Council is fatally flawed, dominated by a duplicitous elite and subject to a veto that runs against the grain of law altogether" and yet, he notes that the Security Council is called to intervene in states such as Syria or Libya in line with the existing "rule of law or some concept of 'non-arbitrariness'.,"775 With all its

${ }^{470}$ Ibid., pg. 131.

${ }^{471}$ Colin Warbrick, 'The principle of sovereign equality' in Colin Warbrick and Vaughan Lowe, Editors, The United Nations and the Principles of International Law, Essays in Memory of Michael Akehurst, Routledge, 1994, pg. 211

${ }^{472}$ ICJ Statute, Article 10. 2.

${ }^{473}$ Gerry Simpson, Great Powers and Outlaw States: Unequal Sovereigns in the International Legal Order, Cambridge University Press, 2004, pg. 7.

${ }^{474}$ United Nations Charter, Article 28, para. 1.

${ }^{475}$ Gerry Simpson, Great Powers and Outlaw States Redux, 43 Neth. YBIL 83 (2013), pg. 92. 
faults, the Security Council remains the most important Organ of the world dealing with world peace. In these lines, around five decades ago Kooijmans stated:

"the mere statement that the League of Nations and the United Nations Organization clash with justice in this (the principle of equality of states) and other respects, as is expressed frequently, does not suffice. If these organizations are the only means to a better international community, we must take this fact into account when assessing their value. Without falling into the trap of naïve positivism, we have to judge the juridical value of the constitutions of international ororganizations by norms and principles, whose meaning has also been determined by historical development." ${ }^{476}$

\section{THE GENERAL ASSEMBLY}

The General Assembly of the United Nations was established by the United Nations Charter in 1945 and represents the main deliberative organ of the UN. In line with the principle of equality of states "each nation, rich or poor, large or small, has one vote". ${ }^{477}$ This makes it the greatest plenary organ in the world with almost universal membership. ${ }^{478}$ Besides having the same voting powers, each state is equal also in representation as no state may have more than five representatives. The GA Rules of Procedure also determine that a Member cannot have more than five alternate representatives and dependent on its capacity as many advisers, technical, experts as required. ${ }^{479}$ According to Article 20 of the Charter, the GA meets in regular annual sessions and special sessions as required, which can be convoked at the request of the SC or the majority of Members. Regular sessions are from September to December each year, or as required. This is less frequent, especially in regard to the continuous sessions of the Security Council. However, in practice, the GA regular session tend to last longer, and close near to the beginning of the next session. With all of its various meetings, the GA is essentially in continuous session, which may cause difficulties in participation for some members having scarce resources. ${ }^{480}$

The General Assembly has rather broad coverage of UN issues as it:

\footnotetext{
${ }^{476}$ Peter H. Kooijmans, The Doctrine of Legal Equality of States: An Inquiry Into the Foundations of International Law, A. W. Sythoff, 1964, pg. 4. Kooijmans considers that there is nothing wrong with the veto power, as the position of the Great Powers "must not be seen as a privilege; it is a right, conferred upon grounds ensuing from the essence of law, because it is the counterpart of a special obligation, a special responsibility laid upon the Great Powers. International peace and security are largely dependent upon the extent to which the Great Powers are prepared to maintain them", see pg. 242.

${ }^{477}$ Quote from the official web site of the General Assembly of the UN at: http://www.un.org/en/ga/, (visited March 2013).

${ }_{478}$ See United Nations Charter, Article 18, para. 1 on voting rights and Article 9, para. 2 on representation.

${ }^{479}$ Rules of Procedure of the General Assembly, Rule 25.

${ }^{480}$ Marie-Claude Smouts, 'The General Assembly: Grandeur and Decadence' in Paul Taylor and A. J. R. Groom, Editors, The United Nations at the Millennium: The Principal Organs, Continuum International Publishing Group, 2003, pg. 35.
} 
"may discuss any questions or any matters within the scope of the present Charter or relating to the powers and functions of any organs provided for in the present Charter, and, except as provided in Article 12, may make recommendations to the Members of the United Nations or to the Security Council or both on any such questions or matters. ",481

The resolutions of the General Assembly, however, are not legally binding. Though not binding, they can influence world affairs and focus attention on specific issues of interest. The General Assembly has other important powers as well, such as approving the United Nations budget, electing the non-permanent members of the Security Council, the members of the ECOSOC and of the Trusteeship Council ${ }^{482}$ as well as members of other United Nations Councils and organs. ${ }^{483}$ Upon the recommendation of the SC, the GA also appoints the Secretary General and together with the SC elects judges of the ICJ. ${ }^{484}$ In addition, upon the recommendation of the Security Council, the GA decides on some fundamental issues in regard to UN membership such as: admission, suspension and expulsion. ${ }^{485}$ It can establish subsidiary organs in performing its functions as it deems necessary. ${ }^{486}$

The Charter determines that decisions on important questions in the GA are made by a two-thirds majority of members present and voting. ${ }^{487}$ Such a majority is required for making recommendations on maintenance of international peace and security, the election of the non-permanent members of the Security Council, members of the ECOSOC, members of Trusteeship Council, admission of new members, suspension, expulsion, operation of the trusteeship system and budgetary questions. ${ }^{488}$ Other issues, including determinations on questions to be decided by a two-thirds majority, are decided by a simple majority. ${ }^{489}$ While decisions in the General Assembly are passed either by a two thirds or a simple majority, special efforts have been made in recent years to achieve consensus. The President of the GA, after achieving such a consensus, may propose to adopt resolutions by consensus without a vote. ${ }^{490}$ According to one

\footnotetext{
${ }^{481}$ United Nations Charter, Article 10. The exception of Article 12 of the Charter as mentioned with regard to the issues on international peace and security dealt by the Security Council.

${ }^{482}$ As stated, the Trusteeship Council is no longer operational and as a result this is hardly an important function of the GA.

${ }^{483}$ United Nations Charter, Article 18.

${ }^{484}$ United Nations Charter, Article 97; ICJ Statute, Article 8.

${ }^{485}$ See United Nations Charter, Article 4, 5 and 6.

${ }^{486}$ United Nations Charter, Article 22.

487 The phrase "members present and voting" means the GA members' casting their affirmative or negative vote, however members abstaining from voting are not considered voting. See Rules of Procedure of the General Assembly, Rule 86.

${ }^{488}$ United Nations Charter, Article 18, para. 1. Also see Rules of Procedure of the General Assembly, Rule 83 A meeting may be declared open if at least one third of the GA members are present however for any decision to be taken the presence of the majority is required, see Rules of Procedure of the General Assembly, Rule 67. ${ }^{489}$ United Nations Charter, Article, 18, para. 2. Also see Rules of Procedure of the General Assembly, Rule 85.

${ }^{490}$ General Assembly of the UN web page at http://www.un.org/en/ga/about/background.shtml, (visited May 2013)
} 
study, as of late 70's almost two-thirds of Resolutions in the GA have been adopted by consensus without casting a vote. ${ }^{491}$

According to some authors, the decisions of the General Assembly of the UN adopted by majority and short of unanimity are in breach of the principle of sovereign equality. ${ }^{492}$ However, as mentioned in the previous chapter, it would be difficult to argue that the GA decision-making by majority is not in line with equality of states as each state is equal in votes and in representation.

While the GA rule of one-vote-one member has been praised for respecting the principle of equality of states, it has also received criticism. And again, among others, the microstates are to be blamed. For example, according to one estimate of 1964, in theory a two thirds majority at the General Assembly could be achieved by Member States of the UN, representing $10 \%$ of the world population and $5 \%$ of contributions to the budget. ${ }^{493}$ According to another study in 1971, states representing less than $0.2 \%$ of the world population through the one member one vote principle can have more the 1/3 of UN votes. ${ }^{494}$ And as stated in the previous chapter III, a majority of 173 UN Members having 173 votes or $89.63 \%$ of the total votes (out of the 193 in total), represent "only" $29 \%$ of the world population, $19.1 \%$ of world GDP and $32.71 \%$ of the territory of states per sq. $\mathrm{km}$. The remaining 20 votes or $10.36 \%$ of the total votes represent: $71 \%$ of the world population, $80.9 \%$ of world GDP and $67.29 \%$ of the territory of states per sq. $\mathrm{km} .{ }^{495}$ The majority of states may cause inconvenience to the minority of states carrying most of the financial burden of the organization by supporting or proposing expensive programs in the GA in a situation where their financial participation is quite symbolic. ${ }^{496}$ Therefore, calls for reform in the GA have also explored the opposite idea of the principle of equality, that of weighted voting. Weighted voting (as in the IMF, IBRD, IFC and IDA) can be an alternative for the General Assembly, although it is very unlikely to occur as any amendments of the Charter would require a two-third majority. ${ }^{497}$ Moreover, resort to weighted voting would also represent a deviation from the principle of equality of states.

\footnotetext{
${ }^{491}$ Marie-Claude Smouts, 'The General Assembly: Grandeur and Decadence' in Paul Taylor and A. J. R. Groom, Editors, The United Nations at the Millennium: The Principal Organs, Continuum International Publishing Group, 2003, pg. 31.

${ }^{492}$ Athena Debbie Efraim, Sovereign (In)equality in International Organizations, Martinus Nijhoff, 2000, pg. 116, 119.

${ }^{493}$ Richard N. Gardner, United Nations Procedures and Power Realities: The International Apportionment Problem, 59 Proc. Am. Soc. Int’l. L. 232 (1965), pg. 233.

${ }^{494}$ Henry G. Schermers \& Niels M. Blokker, International Institutional Law, Fifth Revised Edition, Martinus Nijhoff Publishers, 2011, pg. 65.

${ }^{495}$ On the disparities between states with regard to population size, GDP and territory, see Chapter III, above, pg. 101-114.

${ }_{496}$ Peter R. Baehr and Leon Gordenker, The United Nations: Reality and Ideal, Fourth Edition, Palgrave Macmillan 2005, pg. 44-45.

${ }^{497}$ Richard N. Gardner, United Nations Procedures and Power Realities: The International Apportionment Problem, 59 Proc. Am. Soc. Int'l. L. 232 (1965), pg. 237. The author further argues that this may not be the best solution for the US as no weighted voting in the UN can escape from having the population of a country as an important factor to weigh in. This of course, would mean that China and India would have greater voting power.
} 


\section{EQUALITY OF STATES AND THE DUALISM BETWEEN THE GENERAL ASSEMBLY AND THE SECURITY COUNCIL}

The relative dualism that existed with the Covenant of the League of Nations in regard to the powers of the Council and the Assembly is replaced by the strong decisionmaking powers vested in the Security Council in relation to the General Assembly. ${ }^{498}$ This in itself is a setback as the GA, representing the plenary organ, received fewer powers and functions than did the Security Council.

However it should be noted that in regard to some key issues of the UN, the two most important organs, though not fully equal, yet are very much interdependent as neither can do without the other. For the application of the principle of equality, it is important to note that the GA (as the main plenary body) has significant powers in decision-making. If analyzed, the relation between the General Assembly and the Security Council on a number of important issues is a balanced one as neither can pass a decision without jointly agreeing. Such a situation rests in regard to key components of membership: acquisition, suspension and expulsion.

In regard to the acquisition of membership there is interaction between the two organs on admission but no interaction on original members (which as mentioned was primarily decided by the Big Three). In regard to admission, the GA cannot admit an applicant without the SC recommendation, and neither can SC admit an applicant without the two thirds majority of the GA.

With regard to suspension, the legal provision is similar to the one on admission as the SC recommends but the GA decides, the difference is that with regard to restoring these rights, the $\mathrm{SC}$ decides on its own.

With regard to expulsion, the SC recommends and the GA decides.

Therefore in some key elements of membership: such as admission, suspension and expulsion, the concurring opinions of both the GA and SC are required in order to pass a decision.

\section{THE INTERNATIONAL COURT OF JUSTICE}

The International Court of Justice is the principal judicial organ of the United Nations. ${ }^{499}$ The Statute of the International Court of Justice is annexed to the UN Charter and represents an integral part of the Charter ${ }^{500}$ Article 93 of the Charter, stating that all

\footnotetext{
${ }^{498}$ See for comparison the Covenant of the League of Nations especially Article 3 on the powers of the Assembly, Article 4 on the powers of the Council, Article 5 on decision-making requiring for unanimity in both bodies and UN Charter Chapter IV on the functions and powers and decision-making in the General Assembly with Chapter V on the functions and powers and decision-making in the Security Council.

${ }^{499}$ United Nations Charter, Article 92; ICJ Statute, Article 1.

${ }^{500}$ United Nations Charter, Introductory note, Article 92.
} 
the members of the United Nations are parties to the ICJ Statute is superfluous, as they are parties to the Charter, which has as an integral part the Statute of the ICJ. ${ }^{501}$

The application of the principle of equality of states in international courts or the "supernational judicial tribunals" is reflected in the composition, procedure and authority of the court. ${ }^{502}$

As mentioned, the ICJ and UN Secretariat are made up of individuals that do not represent individual states and are not bound by the will of the state whose nationals they are. This significantly differentiates these private individuals from state representatives, which has an important relevance to the principle of the equality of states. The ICJ is composed of fifteen independent judges, regardless of nationality, from among persons of high moral character, who possess the qualifications required in their countries for highest judicial offices, or have recognized competence in international law. ${ }^{503}$ No two judges may be nationals of the same state and if by any chance in the election process more than one national of a state is elected then the eldest will be considered to have been elected. ${ }^{504}$

The Secretary General prepares the list of proposed judges nominated by the national groups of the Permanent Court of Arbitration, or in cases when UN members are not members of that Court, nominations are made by national groups established for this purpose by their governments. ${ }^{505}$ The General Assembly and the Security Council independently elect members of the Court by an absolute majority of votes by both bodies, without making a distinction between the votes of the permanent and nonpermanent members of the Security Council. ${ }^{506}$ It seems that the election of ICJ judges is one of the rare opportunities for the non-permanent members of the SC to be equal with the permanent ones. Each member has one vote and no veto power, thus the principle of equality of states is applied. Also, with regard to the position of the GA and SC, there is equality in terms of respecting the will of the GA, whose concurrent vote is required for the election of judges to take place. In practice this power is substantial though there is quite a difference between the required majority of the 193 votes of the GA and the majority of the 15 votes of the Security Council. This again does not place the permanent and non-permanent members on equal footing as the value of the individual votes in smaller majorities is much greater than in small ones. Another striking inequality is that the 15 states represented at the Security Council also vote in the General Assembly. This balance of powers between the GA and SC as a model may be the way forward to further develop the principle of equality of states. Such a situation, when there is equality in the decision-making between a plenary organ represented by

\footnotetext{
${ }^{501}$ Hans Kelsen, Membership in the United Nations, 46 Colum. L. Rev. 391 (1946), pg. 398; United Nations Charter, Article 93.

${ }^{502}$ Edwin DeWitt Dickinson, The Equality of States in International Law, Harvard University Press, 1920, pg. 322.

${ }^{503}$ ICJ Statute, Article 2,

${ }^{504}$ ICJ Statute, Article 2, Article 3, Article 10, para. 3.

${ }^{505}$ ICJ Statute, Article 4, para. 2, Article 5.

${ }^{506}$ ICJ Statute, Article 8, Article 10, para. 1 and 2.
} 
all members equally and a non plenary organ having limited membership can ameliorate substantially inequality in representation and decision-making as a decision cannot be adopted without the will of the plenary organ.

If after the first round of voting there is no election than a second and even a third meeting will be held. ${ }^{507}$ If after three meetings the GA and SC have not successfully elected the judges of the Court, a committee of three representatives from the GA and three from the SC may be established, with the task of choosing by an absolute majority a name to submit to the SC and the GA for acceptance of a judge..$^{508}$

Article 31 of the Statute seems also to be of interest to the application of the principle of equality of states as it retains the right of a judge to sit in a case even if it has the same nationality as one of the parties of the dispute. ${ }^{509}$ Having in mind that the judges having the nationality of the parties retain their rights to sit in the case, the other party may also choose a person to sit as a judge. ${ }^{510}$ And if no judge is a national of any of the parties, then, each of the parties may choose a judge. ${ }^{511}$ There is complete equality in the decision-making by all judges. ${ }^{512}$ This provision is in line with the principle of equality of states as it is not discriminatory and is applicable to all in the same manner. $^{513}$

No private parties, international organizations, customs territories, dominions or any other subject except states may be parties in cases before the Court. ${ }^{514}$ The Court does not make any distinction and is equally applicable to all states. Also according to Article 35 (2) and (3) of the Charter even non-UN-Members can appear before the Court in conditions of equality with UN members. However, there are at least two aspects of inequality in regard to these provisions concerning access to the Court. First, there is inequality within the Members of the United Nations as some, as the above mentioned Soviet Republics of Ukraine and Belarus or India and the Philippines were not states at the time they joined the United Nations. Second, this situation, at least for a while until they reached their statehood, created a situation of inequality in comparison to other such entities that did not have access to the Court due to their lack of statehood and/or membership of UN.

\footnotetext{
${ }^{507}$ ICJ Statute, Article 11. There was a dispute if the term "meeting” means casting a vote or a meeting would mean a session that allows more than one voting to take place. The second position eventually prevailed and was enshrined in the GA and SC Rules of Procedure to allow for a meeting to continue until the election has been made. This, in practice ruled out the possibility for establishing the committee of six which up to day has never been appointed. See Benedetto Conforti and Carlo Focarelli, The Law and Practice of the United Nations, Fourth Revised Edition, Martinus Nijhoff Publishers, 2010, pg. 145.

${ }^{508}$ ICJ Statute, Article 12.

${ }^{509}$ And if in the Bench there is a judge of the nationality of one of the parties than any other party may also choose a judge and if there is no judge of the nationality of the parties each of the parties may also choose a judge. See ICJ Statute, Article 31, para.2 and 3.

${ }^{510}$ ICJ Statute, Article 31, para. 1 and 2.

${ }^{511}$ ICJ Statute, Article 31, para. 3.

${ }^{512}$ ICJ Statute, Article 31, para. 6.

513 Also see: Bengt Broms, The Doctrine of Equality of States as Applied in International Organizations, Vammala Kirjapaino, 1959, pg. 332-333.

${ }^{514}$ ICJ Statute, Article 34.
} 
Besides the necessary qualifications in the election process of the judges as a whole, due regard is to be given to the representation of the main forms of civilization and principal legal systems of the world. ${ }^{515}$

Though nationality is not formal criteria for selection, it is rather striking that the permanent members of the Security Council tend to have a national as their judge at all times, with very rare exceptions (such as China not having a judge during 19671985). ${ }^{516}$ According to one study about $90 \%$ of the time judges vote for their own states or in favor of similar states as their own in terms of political regime, culture and wealth. ${ }^{517}$ However, the study is inconclusive, as there are many variables and indicators to consider, which very often overlap, making such studies difficult in providing clear-cut conclusions.

\section{THE UN SECRETARIAT}

The UN Secretariat is a Principle Organ of a unitary character supporting the work of all of the UN Principle and Subsidiary Organs, and Treaty Bodies. ${ }^{518}$ The Secretariat is comprised of the Secretary-General (SG) who is the chief administrative officer of the United Nations and such staff as the UN may require. ${ }^{519}$ It is important to make one distinction with regard to the Secretariat. Unlike the other principle organs (ICJ excluded) which are comprised of individuals representing states and casting votes on behalf of the state they represent, the Secretariat is comprised of individuals who take office as private persons, do not represent states and are not bound by the will of any state. ${ }^{520}$ They are international officials. The impartiality of the Secretariat is envisaged in Article 100 of the UN Charter stating that:

"1. In the performance of their duties the Secretary-General and the staff shall not seek or receive instructions from any government or from any other authority external to the Organization. They shall refrain from any action which might reflect on their position as international officials responsible only to the Organization.

2. Each Member of the United Nations undertakes to respect the exclusively international character of the responsibilities of the Secretary-General and the

\footnotetext{
${ }^{515}$ ICJ Statute, Article 9 states " at every election, the electors shall bear in mind not only that the persons to be elected should individually possess the qualifications required, but also that in the body as a whole the representation of the main forms of civilization and of the principal legal systems of the world should be assured"'.

${ }^{516}$ Eric A Posner, Miguel F. P. de Figueiredo, Is the International Court of Justice Biased?, 34 J. Legal Stud. 599 (2005), Footnote 6. pg. 603.

${ }^{517}$ Ibid., pg. 624.

${ }^{518}$ Helmut Volger, 'Secretariat' in Helmut Volger, Editor, A Concise Encyclopedia of the United Nations, Second Revised Edition, Martinus Nijhoff Publishers, 2010, pg.628.

${ }^{519}$ United Nations Charter, Article 97.

${ }^{520}$ Benedetto Conforti and Carlo Focarelli, The Law and Practice of the United Nations, Fourth Revised Edition, Martinus Nijhoff Publishers, Leiden-Boston, 2010, pg.9.
} 
staff and not to seek to influence them in the discharge of their responsibilities. $" 521$

According to Article 97, the Secretary-General is "appointed by the General Assembly upon the recommendation of the Security Council”. The fact that the SG is appointed by the General Assembly (the plenary body) based on the recommendation of the Security Council (the non-plenary body) means that there is a deviation from the principle of equality of states as there is no equality between UN members with regard to representation and voting power in decision-making. While on the one hand the UN Organ that appoints the SG (the GA) is represented by all the UN Member States, on the other hand, the UN Organ that recommends the SG (the SC) has limited membership. In addition, the permanent five in the SC have veto powers providing them with the opportunity to control the appointment process and block any recommendation. ${ }^{522}$ It is obvious that in the appointment of the SG there is non compliance with the principle of equality of states as the permanent members, as well as the non-permanent members of the SC are in a better position compared to the other members of the UN. Moreover, the members of the Security Council (permanent and non-permanent) have an opportunity of dual participation. First, they participate in the decision on the recommendation of the SG as members of the SC, then as members of the GA in the appointment of the SG. Other UN Member States not represented in the SC can only participate in the appointment as members of the GA. From the establishment of the United Nations 8 Secretary Generals have been appointed so far. In chronological order, including their nationality, the SG's appointed so far (June 2013) are: Ban Ki-moon from South Korea (2007ongoing), Kofi A. Annan from Ghana (1997-2006), Boutros Boutros-Ghali from Egypt (1992-1996), Javier Pérez de Cuéllar from Peru (1982-1991), Kurt Waldheim from Austria (1972-1981), U Thant from Burma-now Myanmar (1961-1962 acting SecretaryGeneral, 1962-1971 Secretary-General), Dag Hammarskjöld from Sweden (19531961), Trygve Lie from Norway (1946-1952). ${ }^{523}$

This representation can be better illustrated in the following chart:

Chart 6: United Nations Secretary-Generals by nationality

\footnotetext{
${ }^{521}$ United Nations Charter, Article 100.

522 The decision to provide for veto rights for the permanent five in the recommendation for the appointment of the SG was agreed and adopted during the San Francisco Conference. See Stephen M. Schwebel, Justice in International Law: Selected Writings, Cambridge University Press, 1994, pg. 299.

${ }^{523}$ See the web page of the United Nations Secretary General, at: http://www.un.org/sg/appointment.shtml, (visited May 2013).
} 


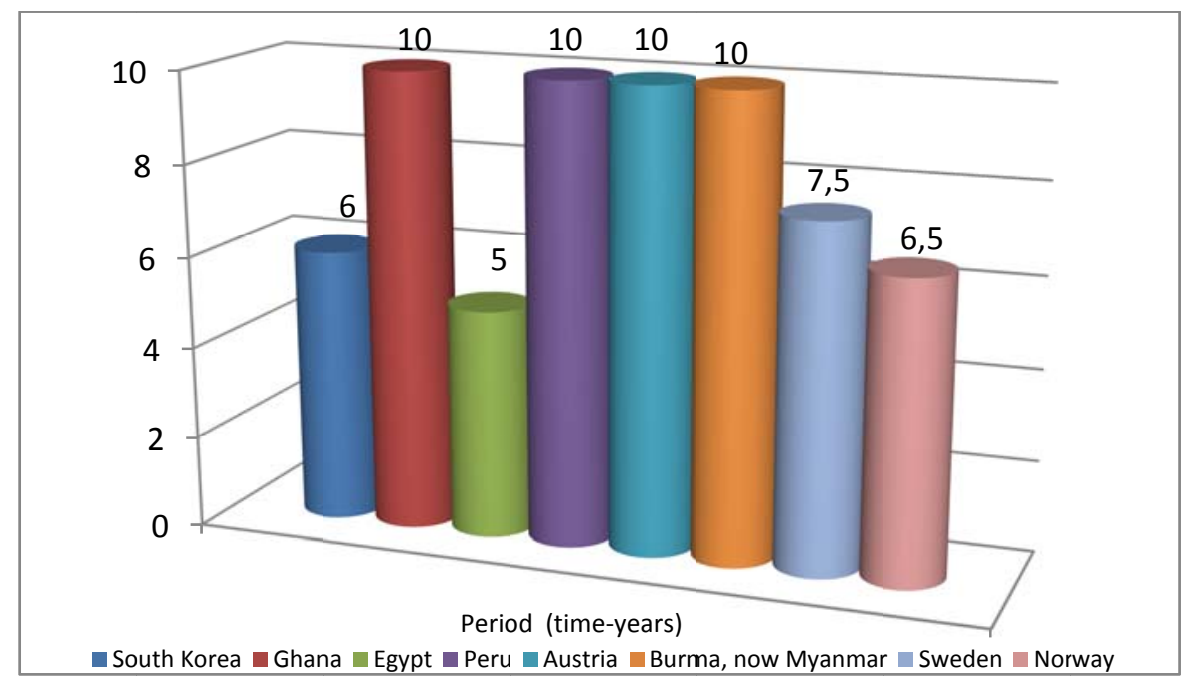

From this chart, it is obvious that the UN Secretary-Generals so far have been nationals of 8 UN Members States. There is no proportional representation with regard to geographical representation of the SG as: three were from Europe (Austria, Sweden, Norway), two from Asia (South Korea and Myanmar), two from Africa (Ghana, Egypt) and one from Latin America (Peru).

Such representation with regard to regional rotation and gender so far did not fulfill the expectation of the General Assembly. Therefore, on September 2006, the General Assembly adopted a Resolution emphasizing the need for an appointment process of the SG that would be inclusive of all members and which would give due regard to regional rotation and gender equality. In particular, the General Assembly:

"Emphasizes, bearing in mind the provisions of Article 97 of the Charter, the need for the process of selection of the Secretary-General to be inclusive of all Member States and made more transparent and that, in the course of the identification and appointment of the best candidate for the post of Secretary-General, due regard should be given to regional rotation and gender equality". ${ }^{24}$

After appointment, the Secretary-General is in charge of appointing the staff of the UN Secretariat. In doing so, the SG, must have in mind the "highest standards of efficiency, competence, and integrity" and the importance "of recruiting the staff on as wide a geographical basis as possible”. ${ }^{525}$ As Schwebel noted, it can be clearly stated that the:

${ }^{524}$ GA Resolution, 60/286, 8 September 2006, p. 18.

${ }^{525}$ United Nations Charter, Article 101. 
"Essential criterion for judging the work of the Secretariat, it may be ventured, is its success in representing the unifying, international element in an Organization and world which are disparate and national.

As of 2011 the Secretariat of the United Nations had 43,747 members of staff employed around the world from 186 UN Members out of which 2049 staff members (as of June 2011) belong to staff appointed based on their geographical status. ${ }^{527}$

According to a Report of the Secretary-General on the Composition of the Secretariat the representation of UN Member States of the staff based on their geographical status can be categorized as: unrepresented ${ }^{528}$, underrepresented ${ }^{529}$, within range ${ }^{530}$ and overrepresented ${ }^{531} .532$ The Report shows that even 20 Member States are unrepresented, 56 are underrepresented, 109 are within range and that 7 Member States (Argentina, Bulgaria, Cameroon, Ethiopia, Kenya, Philippines and the Russian Federation) are overrepresented. $^{533}$

This report shows that even within this relatively limited proportion of the staff belonging to posts assigned based on geographical status of the UN Secretariat; there is much to be desired in terms of equality of states in representation. In fact, the Report was a result of a General Assembly Resolution requesting the SG to "present proposals to effectively increase the representation of developing countries in the Secretariat and to report thereon to the General Assembly". ${ }^{534}$

To sum up, the appointment process of the SG who further on appoints the members of the staff of the Secretariat is based on non compliance of the principle of equality of states with regard to equal representation and voting power of all UN Member States in the decision-making. Furthermore, the UN Secretariat although addressing the issue of geographical representation has yet to achieve this goal in more comprehensive manner. The fact that the first criteria for the appointment of staff is professionalism and not representation of states does provide for significant space for maneuver in justifying at times, the lack of a better representation among Members.

\footnotetext{
${ }^{526}$ Stephen M. Schwebel, Justice in International Law: Selected Writings, Cambridge University Press, 1994, pg. 298.

${ }^{527}$ See the web page of the United Nations Secretariat at: http://www.un.org/en/mainbodies/secretariat/, (visited May 2013). Also see the Report of the Secretary-General, Composition of the Secretariat: staff demographics, A/66/347, 8 September 2011, pg. 46.

${ }^{528}$ No national of a Member State is serving in a post subject to geographical distribution after having gone through the selection process.

${ }^{529}$ The number of appointed nationals of a Member State is below the desirable range limit.

${ }^{530}$ The number of appointed nationals of a Member State is within (between upper and lower) limits of the desirable range.

531 The number of appointed nationals of a Member State exceeds the desirable range.

${ }^{532}$ Report of the Secretary-General, Composition of the Secretariat: staff demographics, A/66/347, 8 September 2011, pg. 46.

${ }^{533}$ For information on all Member States' position within the four groups of representation see the Report of the Secretary-General, Composition of the Secretariat: staff demographics, A/66/347, 8 September 2011, pg. 47-48.

${ }^{534}$ GA Resolution, 65/247, 8 September 2006, p. 64. In fact, in terms of gender representation, the Resolution expresses "serious concern" that progress toward the goal of having 50/50 gender balance has been slow, see p. 68.
} 
Overall, caution should be exercised in stating whether the Secretariat is in (non) compliance with the principle of equality of states with regard to representation. The individuals that make up the Secretariat do not (at least formally) represent states. However, it can clearly be stated that representation of UN Member States in the composition of the staff of the Secretariat can, and should be enhanced, in order to better represent the diversity of UN Member States. Needles to say, this goal should not be pursued in detriment to principles of quality, professionalism and meritocracy of the individuals that occupy these positions.

\section{UN REFORM AND THE PRINCIPLE OF EQUALITY OF STATES}

While not written in stone, it is in fact extremely difficult to amend or revise the Charter. ${ }^{535}$ This of course does not mean that it is not possible as amendments of the Charter were made in the past. To illustrate, amendment of Article 23 increased representation of Members in the Security Council from eleven to fifteen. ${ }^{536}$ Amendment to the Article 27 increased the required votes for decisions of the Security Council from seven to nine for procedural matters and for all other matters the same but also requiring concurring votes of the permanent five members of the Security Council. Amendments to Article 6 in two occasions increased the number of members of the ECOSOC from 18 to 27 and again from 27 to the current 54 member states. And the last Amendment to Article 109 again increased the number of SC members from the original seven to nine in regards to SC voting for any review of the UN Charter.

In fact, all of the amendments of the UN Charter so far deal with enlarging membership representation and can also be interpreted as an increase of the application of the principle of equality of states in the UN.

Except for these reforms already made, although in the realm of discussion only, the UN reform has been high in the agenda of the organization. Out of the various reform discussions the most important one for the principle of equality of states seem to be the Open-ended Working Group on the "Question of equitable representation on and increase in the membership of the Security Council". ${ }^{537}$ As was noted by Efraim, the Working Group reaffirmed the principle of sovereign equality by noting that:

"it was recognized that the principles of sovereign equality of all Members of the United Nations, equitable geographic distribution and contribution to the maintenance of international peace and security, as well as to the other purposes of the Organization, should guide the work on the reform of the Security Council." $" 538$

\footnotetext{
${ }^{535}$ See UN Charter Articles 108 and 109.

${ }^{536}$ Amendment to Article 23 of the Charter in 1963, entry into force 1965.

${ }^{537}$ GA Resolution, 48 /26, 3 December 1993.

${ }^{538}$ See UN Doc. A/49/965. (1994), pg. 5, reference from Athena Debbie Efraim, Sovereign (In)equality in International Organizations, Martinus Nijhoff, pg. 150-151.
} 
However, as was noted recently by Dunoff, absent from the discussions on Security Council reform are arguments based on sovereign equality. ${ }^{539}$ While this may be true when it comes to the specific use of the concept of "sovereign equality" in the discussions for SC reform, it should be noted (as Dunoff does as well) that the concept of sovereign equality in fact is a rich concept that can be affected even without specific reference to it in the discussion for SC reform. Aware of this fact, Dunoff states:

"Of course, to note that the concept of sovereign equality has not been germane to recent debates over the powers and activities of IOs is not equivalent to claiming - let alone proving - that the concept of sovereign equality should not be part of these debates. Although it is not often invoked, perhaps the term provides a rich conceptualization that can be used to critique or reform current practices. Or perhaps the term can be used to reform contemporary IOs to make them more just, more legitimate, and more effective. "

More important than doing lip-service to the principle of equality of states in the debates related to IGO reform are the real implications of these reforms to the application of the principle of equality of states. Equitable representation and increase of membership of the SC are in line with reform in favor of better application of the principle of equality of states through the amelioration of some of the inequalities set up mainly due to the historical circumstances of WWII!

On the other hand, having in mind that no discussions of SC reforms are conducted with the goal to ensure full equality of representation and voting power of all states, the SC will continue to be in deviation of the principle of equality of states. From this perspective, in fact, the SC reform may only reflect some of the power changes that have occurred since WWII and as a result the SC will continue to be a non-plenary organ with special voting powers only for a small group of UN Members. So far the reform discussions continue with no success, and therefore ironically, the group is at times paraphrased from the "open-ended" group to a "never-ending” working group. ${ }^{541}$

\section{DECISION-MAKING AND THE PRINCIPLE OF EQUALITY OF STATES IN THE UNITED NATIONS}

The principle of equality of states is observed in the UN General Assembly where all UN Member States are represented and have equal voting powers. The majority decision-making process used in the UN GA is in compliance with the principle of equality of states having in mind the equal representation and voting power of all UN Member States. This is also the case with the practice of consensus-decision making in the UN

\footnotetext{
539 Jeffrey L. Dunoff, Is Sovereign Equality Obsolete? Understanding Twenty-First Century International Organizations, 43 Neth. YBIL 99 (2013), pg. 119-120.

540 Ibid., pg. 120.

${ }^{541}$ Benedetto Conforti and Carlo Focarelli, The Law and Practice of the United Nations, Fourth Revised Edition, Martinus Nijhoff Publishers, 2010,pg. 24.
} 
GA which is also in compliance with the principle of equality of states. However, on the other hand, the decision-making processes in the SC are in deviation from the principle of equality of states due to the inequality of representation and voting power of UN Member States in this Organ. While the UN Charter enshrines the principle of equality of states as its first principle, at the same time makes substantial deviations from this principle by limiting representation in the Security Council and by giving veto powers to the permanent five. By doing so, the Charter seems to makes a "compromise between the political requirements of hegemony (or what was termed the "special responsibility" of the great powers) and the juridical commitment to equality (or the dignity and sovereignty of the smaller states). ${ }^{, 542}$ The veto powers of the permanent five represent arguably the greatest deviation from the principle of equality of states in IGOs. As Kooijmans noted, "the right of veto, exercised by the Great Powers in the Security Council, was branded as a flagrant violation of this (equality of states) principle"..$^{443}$

According to Claude the veto power:

"clearly gives each of the great powers the capacity to prevent the operation of the United Nations enforcement system against itself, against any state which it chooses to support and protect, or in any other case in which it prefers not to participate or to have others participate in an enforcement venture under United Nations auspices. ",544

If a so called Great Power belonging to the permanent five is an aggressor, the United Nations would be quite "useless". The veto power has not secured the world from another (world) war. On the contrary, it has established a rule which can block any UN action if and when a permanent five would act as the aggressor. By analogy, let us not forget that when World War II begun, Germany was considered a so called Great Power of its time. On the other hand, the application of the principle of equality of states in the SC entailing equal participation and voting power for all SC members would obviously be even less a good option. It is obvious also from SC reform discussions that this will not be the case even if SC reform would take place.

Caution should be exercised in stating whether in the ICJ and in the Secretariat there is (non) compliance with the principle of equality of states with regard to representation. The individuals that make up these Organs do not (at least formally) represent states. However, it can clearly be stated that representation of UN Member States in the composition of the judges of the ICJ and the staff of the Secretariat can, and should be enhanced, in order to better represent the diversity of UN Member States. Needles to

\footnotetext{
${ }^{542}$ Gerry Simpson, The Great Powers, Sovereign Equality and the Making of the United Nations Charter, 21 Aust. YBIL 133 (2000), pg. 134-135.

${ }^{543}$ Peter H. Kooijmans, The Doctrine of Legal Equality of States: An Inquiry Into the Foundations of International Law, A. W. Sythoff, 1964, pg. 3.

${ }^{544}$ Inis L. Claude Jr., The Management of Power in the Changing United Nations, 15 Int'l. Org. 219 (1961), pg. 225
} 
say, this goal should not be pursued in detriment to principles of quality, professionalism and meritocracy of the individuals that occupy these positions.

\section{THE BUDGET}

The budget has often been a contentious issue in the UN as various countries withheld their financial obligations for various reasons. ${ }^{545}$ Late payment unfortunately has become almost routine behavior for states, thus exposing the Organization to continuous financial crises. ${ }^{546}$

With regard to the decision-making, the General Assembly by a two-thirds majority considers and approves the budget. ${ }^{547}$ As of 1986 , as a result of the insistent request of the greatest financial contributors, the draft budget of the UN is adopted by consensus. ${ }^{548}$ This decision is binding for all and it represents one of the few cases when the GA has such powers. ${ }^{599}$ The consensus decision-making and the binding effect of such a decision is in line with the principle of equality of states. Besides the Charter, the apportionment is further regulated by the Rules of Procedure of the General Assembly, according to which the Committee on Contributions advises the GA on the individual scale of assessments and the capacity to pay per individual member state. ${ }^{550}$ The assessment of the contributions is made based primarily on the Gross National Product (GNP) per country. Failure to pay may invoke suspension of voting rights in the GA according to Articles 5 and 19 of the Charter. The expenses of the United Nations are borne by its members according to the apportionment made by the GA. ${ }^{551}$ The budget of the UN is often been criticized as insufficient. For example, the biennial budget for 2002-2003 was around US\$ 2.5 billion which represented $4 \%$ of the annual budget of New York City or for even a billion dollars less compared to the annual budget of Tokyo's Fire Department. ${ }^{52}$

\footnotetext{
545 The most difficult situations however have always related to instances when the US as the greatest single contributor refused to pay. Such instances with the US began rather late in UN history as of 1980 and especially continued after the famous Kassebaum-Solomon amendment. See Elisabeth Zoller, The "Corporate Will” of the United Nations and the Rights of the Minority, 81 Am. J. Int'l L. 610 (1987), pg. 610.

${ }^{546}$ Benedetto Conforti and Carlo Focarelli, The Law and Practice of the United Nations, Fourth Revised Edition, Martinus Nijhoff Publishers, 2010,pg. 392.

${ }^{547}$ United Nations Charter, Article 17, para. 1, Article 18, para. 2.

${ }^{548}$ Marie-Claude Smouts, 'The General Assembly: Grandeur and Decadence' in Paul Taylor and A. J. R.

Groom, Editors, The United Nations at the Millennium: The Principal Organs, Continuum International Publishing Group, 2003, pg. 49.

${ }^{549}$ Benedetto Conforti and Carlo Focarelli, The Law and Practice of the United Nations, Fourth Revised Edition, Martinus Nijhoff Publishers, 2010, pg. 392.

${ }^{550}$ Rules of Procedure of the General Assembly, Rule 160. Once the scale of assessment is fixed by the GA, it cannot be revised for at least three years unless substantial changes have occurred in the capacity to pay.

${ }^{551}$ United Nations Charter, Article 17, para. 2. The League of Nations also had a similar provision stating that

"the expenses of the League shall be borne by the Members of the League in the proportion decided by the Assembly”. See Covenant of the League of Nations, Article 6, para. 5.

${ }^{552}$ Philippe Sands and Pierre Klein, Bowett's Law of International Institutions, Sixth Edition, Sweet \& Maxwell, 2009, pg. 570.
} 
There has never been a standard of proportionally equal contribution to the UN budget by all UN members and as a result there is no equality of obligations between UN members. Therefore, the financing of the UN is in deviation from the principle of equality of states.

The contribution of the United Stated towards the UN budget was initially 39.89 $\%$, in 1954 it was decreased to $33.33 \%$ and since 2000 has decreased to $22 \%{ }^{553}$ For the most updated example, according to the contributions to the last regular budgets for 2011 and 2012, Member States' financial share in the budget varies from $0.001 \%$ of the budget for the smallest states such as Belize, Bhutan, Burundi, Cape Verde, Central African Republic, Comoros, Djibouti, Eritrea, Gambia, Kiribati, Malawi, Maldives, and up to the 10 most important contributors such as the United States with $22 \%$, followed by Japan 12.530 \%, Germany 8.018 \%, UK 6.604 \%, France 6.123\%, Italy 4.999\%, Canada 3.207\%, China 3.189 \%, Mexico 2.356, and Republic of Korea 2.260\%. ${ }^{554}$

The 10 largest contributors provide for even $71.286 \%$ of the total budget while the remaining 183 members provide for $28.714 \%$ of the budget.

This division in financing can be better illustrated in the following chart:

Chart 7: The share of the 10 largest UN contributors and the remaining 183 UN Members

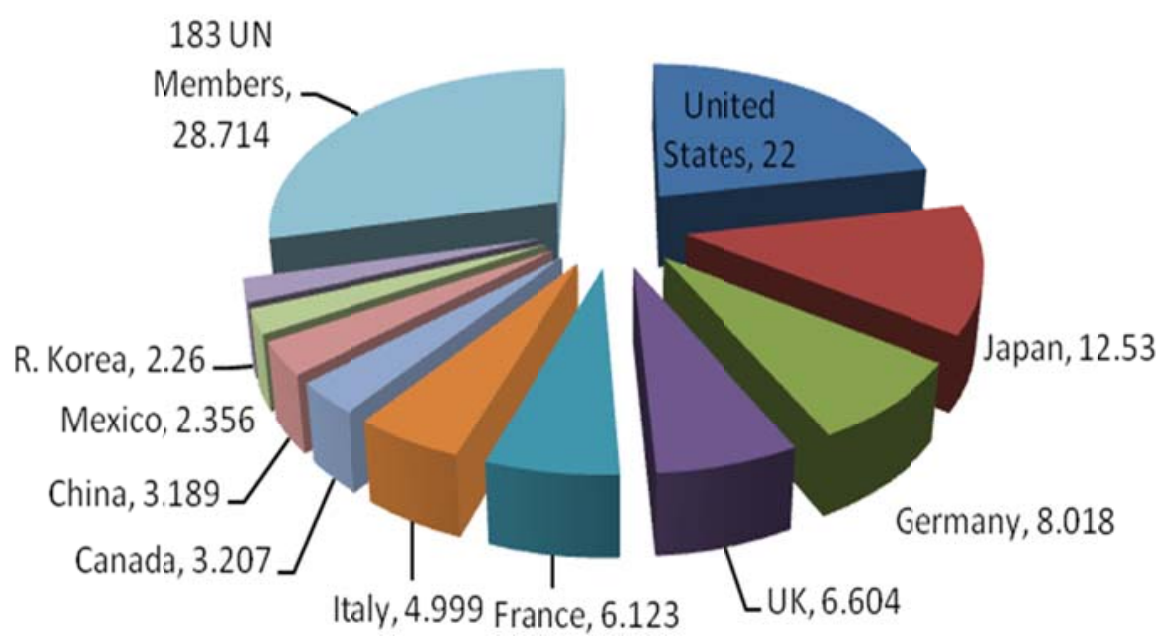

It is obvious, that at least from these budget figures, the most privileged permanent five of the Security Council do not constitute the top five contributors of the UN. China and Russia are not in the top five contributors and are behind in contributions in comparison to a number of countries. For example, China is the 8th largest contributor providing for

\footnotetext{
${ }^{553}$ Ibid., pg. 574.

554 See Assessment of Member State's contributions to the United Nations regular budget for the year 2011, United Nations Secretariat Document, 28, December 2010, ST/ADM/SER.B/824, pg. 2-7 and the United Nations regular budget for 2012, United Nations Secretariat Document, ST/ADM/SER.B/853, 27 December 2011, pg. 2-7.
} 
a smaller financial contribution than the following non-permanent members: Japan with $12.530 \%$, Germany $8.018 \%$, Italy $4.999 \%$, and Canada with $3.207 \%$ of the total budget. The Russian Federation, having also a permanent seat at the Security Council and a veto power is actually the 14th largest contributor with a contribution of 1.602\% of the total budget. Except for the above mentioned non-permanent members, the Russian Federation with its financial contribution is also behind Australia which provides for $1.933 \%$, the Netherlands $1.855 \%$ and Brazil with $1.611 \%$ of the total budget.

These figures do not show any correlation between the financial contributions of members and their rights. Except for the above mentioned difference between the rights of the permanent five and their veto powers and the absence of China and Russia in the top five contributors in the UN there is also a significant difference in the General Assembly. In the General Assembly this results in 183 votes contributing a little more than $1 / 4$ of the budget, while the remaining 10 votes a little less than $3 / 4$ of the budget. In fact if there were an equal distribution of contributions between members the numbers would have been different. All 193 UN Members would contribute with around 0.518\% of the total budget. The US with its $22 \%$ actually contributes as much as 42.46 members or has 1 vote in the GA compared to more than 42 other members proportionally. This also means that in equal contribution instead of the 10 top members contributing for $71.286 \%$ of the total budget, this amount would have been provided by around 138 members. The remaining $28.714 \%$ should have been provided by around 55 members instead of the current 183 UN members.

To sum up, from what is stated above, clearly, there is a deviation from the principle of equality of states in the financing of the UN due to the fact that there is no proportionally equal contribution by its members and as a result no equality of obligations.

\section{SUSPENSION, EXPULSION OR WITHDRAWAL OF MEMBERS IN THE UNITED NATIONS}

Articles 5 and 6 of the Charter determine matters related to suspension or expulsion of members. Upon recommendation by the Security Council, the General Assembly decides on issues of suspension of rights and privileges of a member, as well as expulsion, with a majority of two-thirds of members present and voting. ${ }^{555}$ In the Advisory Opinion of the ICJ on the "Certain expenses of the United Nations" the ICJ held that there is similar wording to the Article 4 (2) on the admission of members to the UN, and therefore it is the Security Council that has to make a recommendation in order for the General Assembly to decide. ${ }^{556}$

\footnotetext{
${ }^{555}$ United Nations Charter, Article 18, para. 2.

${ }^{556}$ Certain expenses of the United Nations (Article 17, para. 2 of the Charter), Advisory Opinion of 20 July 1962, I.C.J. Reports 1962, p.157.
} 
The Charter speaks of suspension or expulsion but to date no such actions have ever been taken in the United Nations. ${ }^{557}$ Though not foreseen in the Charter, neither has any withdrawal occurred so far. The only case mentioned as a possible "withdrawal" was the Indonesian case which is hard to determine as such and will be addressed in the withdrawal section. ${ }^{558}$

\section{SUSPENSION OF MEMBERSHIP}

In regard to the suspension of members, the Charter states that:

" a member of the United Nations against which preventive or enforcement action has been taken by the Security Council may be suspended from the exercise of the rights and privileges of membership by the General Assembly upon the recommendation of the Security Council. The exercise of these rights and privileges may be restored by the Security Council." 559

The SC and the GA had a number of discussions about invoking Article 5 during the 70s with regard to the apartheid regime in South Africa, during the 80s with regard to the Middle East and Palestine, and in the 90s with regard to the situation in Bosnia. In the latter case, it was the FRY (Serbia and Montenegro) to be suspended but, as mentioned no such measure was taken. ${ }^{560}$ Article 19 , with a similar wording and purpose to Article 5, foresees the suspension of voting rights in the General Assembly for a member in arrears in the payment of its financial obligations if the amount equals or exceeds the amount due for the preceding two years. ${ }^{561}$ The General Assembly may permit a Member to vote if the Member failed to pay its dues because of conditions beyond its control. ${ }^{562}$ According to Conforti, Article 5 has the power of "total suspension", in that it suspends all the rights and privileges of membership while Article 19 foresees a "kind of partial suspension" as it suspends voting rights only in the General Assembly while the state retains all the other privileges and rights.

In regard to the principle of equality of states, and especially of Article 5 on suspension, one can see a stronger position of the SC as it makes the recommendation but also can restore the rights and privileges of the suspended member by itself without any power sharing with the GA. In addition, one may presume that no permanent member of

${ }^{557}$ Basic Facts about the United Nations, United Nations Department of Public Information, New York, 2011, pg. 5.

${ }^{558}$ On a short discussion regarding the Indonesian “withdrawal” see below, pg. 183-184.

${ }^{559}$ United Nations Charter, Article 5.

${ }^{560}$ See Repertory of Practice of United Nations Organs, Extracts relating to Article 5 of the Charter of the United nations, Supplement No 5 (1970-1978), Supplement No 6 (1979-1984), Supplement No 8 (1989-1994) volume 1, available at: http://www.un.org/law/repertory/ (visited May 2013).

${ }^{561}$ United Nations Charter, Article 19.

${ }^{562}$ For example such a situation in October 2011 existed with the Central African Republic, Comoros, GuineaBissau, Liberia, Sao Tome and Principe and Somalia however the General Assembly by Resolution 66/14 of 11 October 2011 decided to allow them to vote in the GA. see http:/www.un.org/en/ga/about/art19.shtml (visited November 2011). 
the SC will ever be suspended; as such a suspension would be exposed to their own veto.

This makes for a threefold unlikelihood: first, no basis for suspension can occur (preventive or enforcement measure taken by the SC on a permanent member); second, no recommendation for suspension by the SC can be made; and third, even if conditions one and two occur, the permanent member is in a better position to restore its rights and privileges by influencing the SC compared to other members of the UN.

\section{EXPULSION}

The provision on expulsion in the United Nations Charter was introduced primarily due to the insistence by the Soviet Union first at the Dumbarton Oaks and also at the San Francisco Conference. ${ }^{563}$

Article 6 of the Charter speaks of expulsion as follows:

"A member of the United Nations which has persistently violated the Principles contained in the present Charter may be expelled from the organization by the General Assembly upon the recommendation of the Security Council”.

This has similar wording to the expulsion clause of the League of Nations, stating that:

"any member of the League which has violated any covenant of the League may be declared to be no longer a Member of the League by a vote of the Council concurred in by the Representatives of all the other Members of the League represented thereon." 564

In regard to the privileged position of the permanent five in expulsion, all the above mentioned arguments in regard to suspension are also valid here.

\section{IS THERE A RIGHT TO WITHDRAW FROM THE UNITED NATIONS?}

There is neither a withdrawal clause nor is the term "termination" of membership used in the Charter.

The right to withdraw according to the First Commission report at San Francisco is a right that "each state possesses on the basis of the principle of the sovereign equality of the members" and further on Committee I/2 working under the Commission in its

\footnotetext{
${ }^{563}$ See Konstantinos D. Magliveras, Expulsion from Participation in International Organizations: The Law and Practice Behind Member States’ Expulsion and Suspension of Membership, Kluwer Law International, 1999, pg. 32-35.

564 Covenant of the League of Nations, Article 16, para. 4. In fact similarly to the UN, the draft Covenant of the League of Nations did not contain any withdrawal clause. As a result of criticism by the Congress, President Wilson took the stand the Covenant cannot be accepted by the US without a withdrawal clause. See, Josephine Joan Burns, Conditions of Withdrawal from the League of Nations, 29 Am. J. Int'l. L. 40 (1935), pg. 40-41.
} 
report to the plenary conference of San Francisco regarding the commentary on withdrawal, stated the following:

"the Committee adopts the view that the Charter should not make express provision either to permit or to prohibit withdrawal from the Organization. The Committee deems that the highest duty of the nations which will become Members is to continue their cooperation within the Organization for the preservation of international peace and security. If, however, a Member because of exceptional circumstances feels constrained to withdraw, and leave the burden of maintaining international peace and security on the other Members, it is not the purpose of the Organization to compel that Member to continue its cooperation in the Organization". ${ }^{565}$

The most debatable example of withdrawal is the case of Indonesia. On January the 20, 1965, Indonesia announced its decision to withdraw from the United Nations and on the September 19, 1966 expressed its desire to resume its cooperation, a desire granted by the General Assembly on the 28 September $1966 .{ }^{566}$ This period of withdrawing and resuming cooperation creates a debate if withdrawal occurred or not. A simple answer would be that if it occurred a member cannot resume cooperation but can apply for readmission.

For a while, the flag and name plate of Indonesia were removed, the GA did not list it in the assessment of contribution list for 1964, and the Economic and Social Council elected successors of Indonesia in a number of Commissions. ${ }^{567}$ With due regard to specific details in terms of participation in UN organs, the UN budget, the approach taken by the UN was that Indonesia in fact did not withdraw from the Organization, but that a cessation of cooperation took place. ${ }^{568}$ However, Indonesia several times mentioned in its letter that it intended to "withdraw" and if this was the case, the only possibility for Indonesia to return to the UN was through the admission process of Article 4.

According to Schwelb, a member state can withdraw from the UN only in exceptional circumstances as mentioned in the commentary and a withdrawal in cases other than the exceptional circumstances is not permissible and constitutes a violation of international obligations. ${ }^{569}$

${ }^{565}$ Egon Schwelb, Withdrawal from the United Nations: The Indonesian Intermezzo, 61 Am. J. Int'l. L. 661 (1967), pg. 662-663.

566 United Nations web page, link on the Member States of the United Nations, at: http://www.un.org/en/members/index.shtml, (visited March 2013).

567 See Henry G. Schermers \& Niels M. Blokker, International Institutional Law, Fifth Revised Edition, Martinus Nijhoff Publishers, 2011, pg. 107.

${ }^{568}$ Egon Schwelb, Withdrawal from the United Nations: The Indonesian Intermezzo, 61 Am. J. Int'l. L. 661 (1967), pg. 670.

${ }^{569}$ Ibid., pg. 671-672. 


\section{CONCLUSION}

The application of the principle of equality of states in the United Nations is of outmost importance for at least two reasons. The United Nations is arguably the most important international organization of our time and the UN Charter has profound significance to international law. Having in mind that the League of Nations did not have any direct references to the principle of equality of states, the references in the UN Charter are of importance for the formal establishment of the principle of equality of states in international organizations. Moreover, according to the UN Charter, the United Nations is an organization based on the principle of sovereign equality of states.

With regard to acquisition of membership there were deviations from the principle of equality of states both when it comes to original membership as well as in the admission process. The participation in the preparatory work and the possibility to influence the content of the Charter was rather limited to the Big Three, then to the Big Five and eventually to the states considered by them as eligible to receive invitations to participate in the San Francisco conference. Participation at the San Francisco Conference was the main condition to acquire original membership in the United Nations. The admission process for quite some time was also in deviation from the principle of equality of states when subject to interpretation dependent on political bias and not on UN law on admission. Furthermore, interpretations of the legal provisions on admission were not conducted in good faith as provided by the UN Charter and the Vienna Convention on the Law of Treaties.

With regard to decision-making the principle of equality of states has not been upheld when it comes to: representation and voting powers. While on the one hand the UN enshrines the principle of sovereign equality of states as its first principle, the composition, voting powers and the functions of the Security Council represent arguably the most significant deviation from the principle of equality of states. The veto powers of the permanent five and their exclusive membership of the members of the Security Council are considered a deviation from the principle of equality of states. As a result, the permanent members of the Security Council have a unique position providing them equally will more rights in comparison to all other members. As stated by Claude "in the eyes of the Charter, they (the permanent five) are equal". ${ }^{570}$ This cannot be said to be the case for the remaining 188 members of the United Nations. As discussed, even with regard to non-permanent membership of the Security Council there is no equality of representation between states. However, as discussions on the Security Council reform suggest, while there may be an increase in the membership of the SC there is no discussion for a SC that would provide for equal representation and equal voting powers for all UN members. As such, even a reformed SC would be in deviation from the

${ }^{570}$ Inis L. Claude, Jr., A Scholar's Beginnings: A Study of the San Francisco Charter, 40 Va. J. Int'l. L. 311 (1999-2000), pg. 322. 
principle of equality of states although it may ameliorate some of the inequalities by increasing participation of members in the SC.

The General Assembly on the other hand represents the most universal plenary organ in the world where all members, in line with the principle of equality of states, are equally represented and have equal voting powers. The use of majority decision-making in the GA is not a deviation from the principle of equality of states though the practice of using consensus as the primary decision-making mode enhances legitimacy and is also in compliance with the principle of equality of states.

Caution should be exercised in stating whether in the ICJ and in the Secretariat there is (non) compliance with the principle of equality of states with regard to representation due to the fact that the individuals that make up these Organs do not represent states. However, it can clearly be stated that representation of UN Members in the composition of the ICJ and the Secretariat staff can, and should be enhanced, in order to better represent the diversity of UN Member States. However, this goal should not be pursued in detriment to principles of quality, professionalism and meritocracy of the individuals that occupy these positions.

With regard to the budget, there is no equal financial contribution by the UN members. Moreover, two of the permanent five, seem to provide much lower financial contributions towards the UN in comparison to the remaining three permanent members, and more strikingly, also in comparison to other UN members. The overall division of the budget between members represents a deviation from the principle of equality of states as there is no equality of obligations between states.

With regard to suspension and expulsion for the UN, it is obvious that the Security Council in general and the permanent members in particular are in more privileged positions in comparison to the General Assembly and other UN members. While on the one hand, the Security Council decision is required for such actions to take place on the other, it is not viable to expect that any such measures can be imposed on the permanent members of the SC as they can always veto any such decision. This places the members of the Security Council in a more privileged position. 


\section{CHAPTER V \\ THE PRINCIPLE OF EQUALITY OF STATES IN THE WORLD TRADE ORGANIZATION}

\section{INTRODUCTION}

The World Trade Organization is the youngest of the major intergovernmental organizations and possibly one of the most influential in times of economic globalization. ${ }^{571}$ With the probable exception of the UN, the WTO is described as the "most important international organization in existence" and the "central illustration of legal and jurisprudential developments influenced by phenomena of our contemporary world”. ${ }^{772}$ While the UN is focusing on maintaining international peace, the WTO focuses on liberalizing trade. Their importance is reflected in the understanding that peace and trade are very much related or as the popular saying goes “when goods don't cross borders, soldiers will”. Similarly, Montesquieu had once stated that "peace is the natural effect of trade". 573

The WTO was established as an international organization on 1 January 1995 as the result of the Uruguay Round and the adoption of the Marrakesh Agreement Establishing the World Trade Organization (hereinafter the WTO Agreement). ${ }^{574}$ Article I of the WTO Agreement solemnly declares that: "the World Trade Organization (hereinafter referred to as "the WTO") is hereby established". 575

The fact that the WTO is an international organization should not be taken for granted as it took 50 years for an international organization dealing with trade matters to

\footnotetext{
${ }^{571}$ Peter Van den Bossche, Werner Zdouc, The Law and Policy of the World Trade Organization: Text, Cases and Materials, Third Edition, Cambridge University Press, 2013, pg. 74.

${ }^{572}$ John H. Jackson, Sovereignty, the WTO and Changing Fundamentals of International Law, Cambridge University Press, 2006, pg. 16, 19.

${ }^{573}$ Peter Sutherland et al. The Future of the WTO: Addressing Institutional Challenges in the New Millennium (The Sutherland Report), Geneva: WTO, 2004, pg. 15. There is a presumption that nations that have developed trade relations in general terms do not wage wars among themselves. Though there are cases were exactly trade problems were the casus belli, see John H. Jackson, Sovereignty, the WTO and Changing Fundamentals of International Law, Cambridge University Press, 2006, pg. 46-47.

${ }^{574}$ The main legal source of the WTO is the Marrakesh Agreement Establishing the World Trade Organization. The scope of the Marrakesh Agreement represents the most ambitious and far reaching trade agreement. The WTO Agreement comprises more than 25.000 pages, including its Annexes. Of this, 95\% consists of Schedules of Concessions (concerning trade in goods) and of Schedules of Specific Commitments (concerning trade in services).

${ }^{575}$ The WTO Agreement, Article I.
} 
be formally established ${ }^{576}$ Its predecessor, the General Agreement on Tariffs and Trade 1947 (hereinafter the GATT) was in fact not a de jure international organization. The drafters of the WTO Agreement completed the transformation from the GATT "de facto" type to the WTO "de jure and de facto" international organization by granting legal personality to the WTO in Article VIII of the WTO Agreement. ${ }^{577}$ Unlike the GATT, the WTO also regulates a much broader area of trade and other trade related issues. While the GATT was dealing only with trade in goods, the WTO today deals with also trade in services and intellectual property rights, and a well-developed institutional and governance system.

As an international organization, the WTO provides for the common institutional framework for trade relations among its members. ${ }^{578}$ The main purpose of the organization is to open trade for the benefit of all. ${ }^{579}$ The WTO is a universal organization with 159 members (March 2013) representing all major trading as well as developed countries with more than $99.5 \%$ of world population and more than $97 \%$ of world trade..$^{580}$ Out of the current 159 members the vast majority of them, or 155 WTO members are states $^{581}$, three are customs territories ${ }^{582}$ and one WTO member, the European Union is an international organization. ${ }^{583}$ This threefold membership is a distinctive feature of the WTO among major international organizations. It should be immediately noted that the EU as an international organization, through the European Commission speaks at the

${ }^{576}$ Pascal Lamy, The Place of the WTO and its Law in the International Legal Order, 17 Eur. J. Int'l. L. 969 (2007), pg. 971.

${ }^{577}$ Besides granting legal personality to the WTO, this provision further accords the necessary privileges and immunities to the WTO, its officials and representatives of all its Members similar to the ones stipulated in the Convention on the Privileges and Immunities of Specialized Agencies of the UN GA of November 21, 1947. See the WTO Agreement, Article VIII:1-5.

578 The WTO Agreement, Article II:1.

${ }^{579}$ A mission statement by the Director General about the WTO, at http://www.wto.org/english/thewto_e/whatis_e/wto_dg_stat_e.htm, (visited March, 2013).

${ }^{580}$ Peter Van den Bossche, Werner Zdouc, The Law and Policy of the World Trade Organization: Text, Cases and Materials, Third Edition, Cambridge University Press, 2013, pg. 104.

581 Albania, Angola, Antigua and Barbuda, Argentina, Armenia, Australia, Austria, Bahrain, Bangladesh, Barbados, Belgium, Belize, Benin, Bolivia, Botswana, Brazil, Brunei, Bulgaria, Burkina Faso, Burundi, Cambodia, Cameroon, Canada, Cape Verde, Central African Republic, Chad, Chile, China, Colombia, Congo, Costa Rica, Cote d'lvoire, Croatia, Cuba, Cyprus, Czech Republic, DR Congo, Denmark, Djibouti, Dominica, Dominican Republic, Ecuador, Egypt, El Salvador, Estonia, Fiji, Finland, FYR Macedonia, France, Gabon, Gambia, Georgia, Germany, Ghana, Greece, Grenada, Guatemala, Guinea, Guinea Bissau, Guyana, Haiti, Honduras, Hungary, Iceland, India, Indonesia, Ireland, Israel, Italy, Jamaica, Japan, Jordan, Kenya, Korea, Kuwait, Kyrgyz Republic, Latvia, Lesotho, Liechtenstein, Lithuania, Luxembourg, Madagascar, Malawi, Malaysia, Maldives, Mali, Malta, Mauritania, Mauritius, Mexico, Moldova, Mongolia, Montenegro, Morocco, Mozambique, Myanmar, Namibia, Nepal, Netherlands, New Zealand, Nicaragua, Niger, Nigeria, Norway, Oman, Pakistan, Panama, Papua New Guinea, Paraguay, Peru, Philippines, Poland, Portugal, Qatar, Romania, Russian Federation, Rwanda, Saint Kitts and Nevis, Saint Lucia, Saint Vincent and the Grenadines, Samoa, Saudi Arabia, Senegal, Sierra Leone, Singapore, Slovak Republic, Slovenia, Solomon Islands, South Africa, Spain, Sri Lanka, Suriname, Swaziland, Sweden, Switzerland, Tanzania, Thailand, Togo, Tonga, Trinidad and Tobago, Tunisia, Turkey, Uganda, Ukraine, United Arab Emirates, UK, USA, Uruguay, Vanuatu, Venezuela, Viet Nam, Zambia, Zimbabwe.

${ }^{582}$ Hong Kong, China; Macao, China; Chinese Taipei.

${ }^{583}$ For a detailed overview of WTO Members including information on the exact dates of their accession, refer to the WTO web page at: http://www.wto.org/english/thewto_e/whatis_e/tif_e/org6_e.htm, (visited March, 2013). 
same time for itself and the 27 states of the EU (28, as of July 2013, with Croatia joining).

The WTO Agreement refers to its members as “countries”. It states that:

"the terms "country" or "countries" as used in this Agreement and the Multilateral Trade Agreements are to be understood to include any separate customs territory Member of the WTO”. ${ }^{84}$

The fact that the WTO has the EU as its member is not fully reflected in the Explanatory Notes of the WTO Agreement according to which the term "country" is to be understood to include any separate customs territory, but makes no mention of an international organization. Does this mean that notion of "country" in the WTO applies to states and customs territories and (not) the European Union? Does the WTO consider the European Union a WTO member “country”? By not having any other specific reference to address the European Union, it seems that the European Union is one of the 159 WTO member "countries". Having in mind this heterogeneous membership of the WTO, one question that needs an immediate answer is whether the principle of equality of states is applicable to all WTO members, irrespective of their status? From the wording of the principle of equality of states, it is quite clear that the principle is applicable only to states. Without a doubt, the principle of equality of states is applicable to almost all WTO members as these members are states. But what about the three separate customs territories and one international organization which are members of the WTO? There are at least two possible answers to this question.

First, if one applies a formalistic and narrow interpretation of the principle of equality of states which by all means is legally valid, then there is a deviation from the principle when states are treated as equals with subjects that by international law have not acquired such a status. Therefore the application of the principle of equality of states in this situation also to the three separate customs territories and to an international organization can be easily viewed as a deviation from the principle of equality of states.

Second, there is no deviation from the principle of equality of states. This position seems to include a more teleological interpretation and is based in the fact that there is positive discrimination or affirmative action by the WTO. Affirmative actions are in line with the principle of equality of states because they aspire to create situations of equality by eradicating conditions of inequality. This may contradict some of the conclusions in the previous chapter noting the admission of Ukraine, Belarus, the Philippines and India to the UN as a deviation from the principle of the equality of states. ${ }^{585}$ By this logic, the admission of Ukraine, Belarus, the Philippines and India to the UN should also be considered as affirmative action. The falsity in such a proposition lay, among others, in the difference between the WTO and the UN in regard to their mem-

\footnotetext{
${ }^{584}$ See WTO Agreement, Explanatory Notes.

${ }^{585}$ On the application of the principle of equality of states in the United Nations, see Chapter IV, above, pg. 121-186.
} 
bership policies. Namely, the UN allows only states to become members and the admission of any non-state entities such as Federal Republics is a deviation from the principle of equality of states per se. The WTO, on the other hand, allows for states, for separate customs territories and an international organization to become members of the organization. By not making any distinction in treatment, the WTO is actually applying the principle of equality for all its members regardless of status. By this account only, in the WTO there seem to be an evolution of the application of the principle of equality of states from member states of international organizations, to all members (not only states) regardless of status. One may also argue that the European Union as an international organization, in practical terms, is a reflection of the $27 \mathrm{EU}$ Member States that at the same time are 27 WTO members. From this perspective, the EU is actually an international organization and 27 states at the same time. To state that the principle of equality of states does not apply to the European Union, at the same time would mean that it does not apply to the $27 \mathrm{EU}$ states that the EU (through the European Commission) represents in the WTO. This would mean a gross deviation from the principle of equality of states.

Therefore the application of the principle of equality of states in the WTO will apply, without any prejudice, to all its members including separate customs territories and the European Union.

This chapter discusses the application of the principle of equality of states in the WTO with regard to the: (1) WTO Agreement; (2) acquisition of membership; (3) decision-making; (4) financing of the WTO; and (5) suspension, expulsion and withdrawal from membership of the WTO.

\section{THE PRINCIPLE OF EQUALITY OF STATES IN THE WTO AGREEMENT}

There is no doubt that the WTO is, as any other international organization, obligated to respect international law and subsequently the principle of equality of states. WTO law is not isolated from international law; in fact it is the principal component of international economic law, which is an important part of public international law. ${ }^{586}$ Sources of WTO law include customary international law and general principles of law. ${ }^{587}$ Jackson strongly supports the position that international economic law and the WTO are part of international law. ${ }^{588}$ In more specific terms, according to Pascal Lamy, the WTO Director-General, the WTO legal order respects among others the principles of international law such as the "sovereign equality of states, good faith, international cooperation

\footnotetext{
${ }^{586}$ Peter Van den Bossche, The Law and Policy of the World Trade Organization: Text, Cases and Materials, Second Edition, Cambridge University Press, 2008, pg. 59-61.

${ }^{587}$ Ibid., pg. 42, 53-61.

${ }^{588}$ John H. Jackson, Sovereignty, the WTO and Changing Fundamentals of International Law, Cambridge University Press, 2006, pg. 48.
} 
and the obligation to settle disputes peacefully." ${ }^{589}$ According to Lamy, the World Trade Organization largely rests on the principle of equality of states. ${ }^{590}$ He further states:

"the sovereign equality of states requires formal equality between states of different sizes and power. This principle is fully respected at the WTO" ${ }^{591}$

According to Mike Moore, a former Director-General of the WTO, the equal rights of WTO members are based in fundamental principles of WTO law reflected in the principles of non-discrimination (MFN and national treatment obligation) and consensus decision-making. ${ }^{592}$

The WTO Agreement, unlike the UN Charter, has no direct references to the principle of equality of states. Although there are no direct references to the principle of equality of states in the WTO Agreement, there a number of legal provisions of relevance to the application of the principle of equality of states. These provisions can be grouped in three categories of rules: first, rules on non-discrimination; second rules on special and preferential treatment (a type of affirmative action, or positive discrimination); and third, rules on decision-making processes. ${ }^{593}$

The first category of rules relate to the principle of non-discrimination in the WTO. This is a core principle of WTO law. Paragraph 3 of the Preamble speaks of "elimination of discriminatory treatment in international trade relations". ${ }^{594}$ The two most crucial non- discrimination rules of the WTO are the one on the most-favoured nation treatment obligation (MFN) and the national treatment obligation (NT) regarding trade in goods, services and trade related aspects of intellectual property rights. ${ }^{595}$ Having in mind that these non-discrimination rules are part of the substantive law and that as such are beyond the scope of this book, they will not be discussed in detail.

The second category of rules concerning the principle of equality in WTO law relates to the special and differential treatment for developing, and especially the least

\footnotetext{
${ }^{589}$ Pascal Lamy, The Place of the WTO and its Law in the International Legal Order, 17 Eur. J. Int'l. L. 969 (2007), pg. 972.

${ }^{590}$ Ibid., pg. 974.

${ }^{591}$ Ibid.

${ }^{592}$ Mike Moore, 'The Democratic Roots of the World Trade Organization' in Patrick F. J. Macrory, Arthur E Appleton, Michael G. Plummer, Editors, The World Trade Organization: Legal, Economic and Political Analysis, Volume I, Springer 2005, pg. 40-41.

${ }^{593}$ Non-discrimination (or equal treatment), together with affirmative action, as stated in the first chapter are concepts of crucial importance to the principle of equality of states.

${ }^{594}$ See WTO Agreement, Preamble, par. 3.

${ }^{595}$ See Article I of the GATT 1994 on the MFN treatment obligation for trade in goods, Article II of the GATS on the MFN treatment obligation for trade in services and Article III of TRIPS on MFN treatment obligation for the protection of intellectual property rights. For national treatment obligation on trade in goods see Article III of the GATT 1994, and Article XVII of GATS on national treatment obligation for trade in services. The MFN and NT treatment obligations prohibit discrimination between WTO members. These rules seem to apply the principle of equality of states (not even states but customs territories and an international organization) in a perfect manner. Any treatment offered to one is offered to everyone else. In the form of the principle of non-discrimination, the principle of equality is reflected fully in the WTO.
} 
developed countries. ${ }^{596}$ In general terms, it is considered that one of the key functions of the WTO, though not explicitly referred to in Article III of the WTO Agreement is to provide developing country Members technical assistance in order to allow them to integrate in the world trading system. ${ }^{597}$ Paragraph 2 of the Preamble of the WTO Agreement states that:

"recognizing further that there is a need for positive efforts designed to ensure that developing countries and especially the least developed among them, secure a share in the growth in international trade commensurate with the needs of their economic development". 598

Almost all of the WTO Agreements contain provisions on special and differential treatment for developing countries which according to their purpose can be grouped in the following six categories: provisions aiming the increase of trade opportunities, safeguarding the interests of these countries, flexibility in commitments undertaken and in the use of policy instruments, transitional time periods, technical assistance and provisions with regard to the least developed countries. ${ }^{599}$ The WTO Agreement also contains specific references for the least-developed country members (LDC's). According to the United Nations there are today 49 states that are considered to be LDC's, which in percentage amounts to around a quarter or $25 \%$ of the 193 UN Members. ${ }^{600}$ The majority of them (34 LDC's) have succeeded to join the WTO either as original members or through the WTO accession. ${ }^{601}$ WTO law applies to LDC's as to the other members of the organization. However, having due regard to their level of development, WTO law has established special provisions providing for special treatment for LDC's and developing countries as well. Article IV:7 of the WTO Agreement states:

\footnotetext{
${ }^{596}$ The Sutherland Report refers for example to special and differential treatment as discrimination. See Peter Sutherland et al. The Future of the WTO: Addressing Institutional Challenges in the New Millennium (The Sutherland Report), Geneva: WTO, 2004, pg. 23.

${ }^{597}$ Peter Van den Bossche, Werner Zdouc, The Law and Policy of the World Trade Organization: Text, Cases and Materials, Third Edition, Cambridge University Press, 2013, pg. 85.

${ }^{598}$ See WTO Agreement, Preamble, para. 2.

${ }^{599}$ See Peter Van den Bossche, The Law and Policy of the World Trade Organization: Text, Cases and Materials, Second Edition, Cambridge University Press, 2008, pg. 723-724. Also see Committee on Trade and Development: Special and Differential Treatment for Least-Developed Countries, Note by the WTO Secretariat, WT/COMTD/W/135 of 5 October 2004.

${ }^{600}$ See the web page of the UN Office of the High Representative for LDC's, Landlocked Developing Countries and Small Islands Developing States at: http://www.unohrlls.org/en/ldc/25/, (visited March, 2013). They represent more than 880 mil. people and account for less than $2 \%$ of World GDP and 1\% of global trade in goods. Out of the 49 LDC's even 34 are in Africa, 14 in Asian and the Pacific and only one in Latin America.

${ }^{601}$ The following 34 least developed countries have joined the WTO: Angola, Bangladesh, Benin, Burkina Faso, Burundi, Cambodia, Central African Republic, Chad, Congo, Djibouti, Gambia, Guinea, Guinea Bissau, Haiti, Lao People’s Democratic Republic, Lesotho, Madagascar, Malawi, Mali, Mauritania, Mozambique, Myanmar, Nepal, Niger, Rwanda, Samoa, Senegal, Sierra Leone, Solomon Islands, Sierra Leone, Solomon Islands, Tanzania, Togo, Uganda, Vanuatu, Zambia. See the WTO members belonging to the Least- Developed countries at the WTO web at: http://www.wto.org/english/thewto_e/whatis_e/tif_e/org7_e.htm, (visited March, 2013).
} 
"the Committee on Trade and Development shall periodically review the special provisions in the Multilateral Trade Agreements in favour of the least-developed country Members and report to the General Council for appropriate action.”

Moreover, the WTO Agreement foresees that the WTO Members belonging to the United Nations list of least developed states:

"will only be required to undertake commitments and concessions to the extent consistent with their individual development, financial and trade needs or their administrative and institutional capabilities. ${ }^{\text {"602 }}$

These rules offering special treatment for developing and especially the LDC members of the WTO are also in compliance with the principle of equality of states. In fact, they represent affirmative type of actions and try to address some material inequalities between WTO members.

The third category of rules, representing the most important aspect of the application of the principle of equality of states in the WTO, discusses the decision-making in the WTO. The WTO rules on decision-making provide for equal representation for all members in all WTO bodies. In addition, WTO law provides for equality of voting powers (no weighted voting or special veto powers) for all its members regardless of power and size. Equality in representation and equality of voting powers ensure full compliance with the principle of equality of states in any of the decision-making processes used. The decision-making rules of WTO for majority or consensus decisionmaking and their compliance with the principle of equality of states will be discussed in more detail in this chapter.

\section{ACQUISITION OF MEMBERSHIP IN THE WTO}

There are basically two ways of becoming a member of the WTO. These are either through acquiring original membership or through the accession process. There is no difference between the rights and obligations of WTO members irrespective of whether they acquired membership status as original members or through accession. However, there is a difference between them when it comes to the various degrees of difficulties encountered in the process of acquiring membership as well as the level of concessions and commitments made with regard to the liberalizing of trade in goods and services. The status of GATT Contracting Party provided for the right to acquire original membership of the WTO and therefore the acquisition of original membership of the WTO is strongly linked to the status of a GATT Contracting Party. The GATT originated from the negotiations between 15 states, initiated in 1945 in London, to reduce and bind customs duties. These negotiations were concluded in 1947 in Geneva with the General Agreement on Tariffs and Trade, a multilateral agreement on tariff reduction with 23

${ }^{602}$ See WTO Agreement, Article XI: 2. 
Contracting Parties. The number of Contracting Parties grew over time from 23 (in 1947) to 128 (in 1994). All but one of these Contracting Parties became in 1995, or shortly thereafter, Members of the WTO. In subsequent years, the membership of the WTO further increased and includes 159 Members as of March 2013. ${ }^{603}$ The increase of the number of GATT Contracting Parties and of WTO Members can be better illustrated in the following chart:

Chart 8: The evolution from GATT Contracting Parties to WTO Members

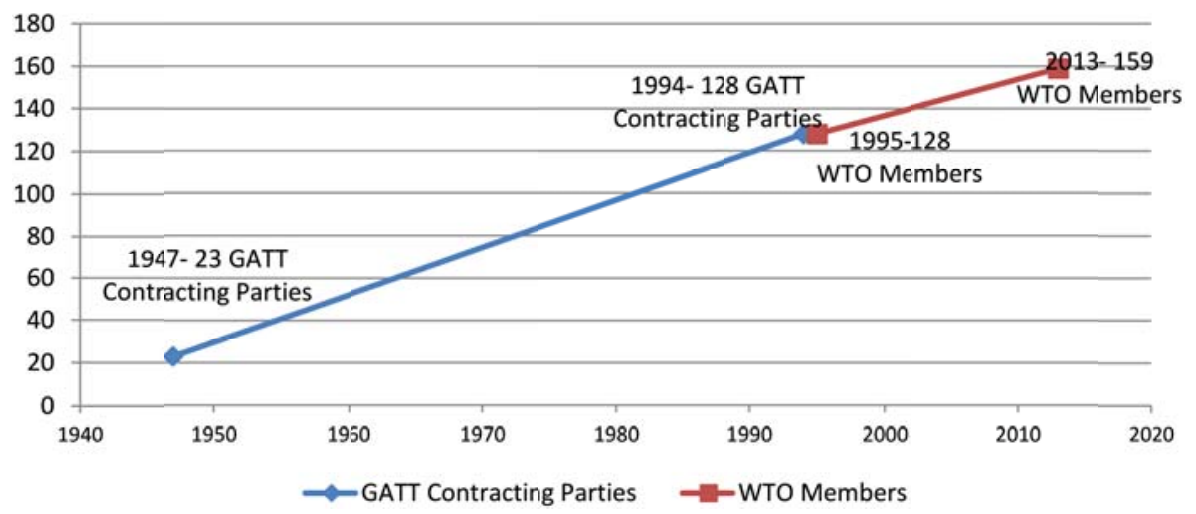

It is clear that the trend of membership expansion throughout the GATT period and the WTO has been intense and continuous, resulting in almost $700 \%$ increase from the initial 23 GATT Contracting Parties in 1947, to the 159 WTO Members in 2013.

The following sections will discuss the principle of equality of states: first in the negotiations for the establishment of the WTO, second in original membership in the WTO and third, in acquisition of membership through the accession process.

\section{THE PRINCIPLE OF EQUALITY OF STATES IN THE NEGOTIATIONS FOR THE ESTABLISHMENT OF THE WTO}

The discussions on the negotiations leading to the establishment of the WTO date back not only to the negotiations for the establishment of the WTO itself, but also to the negotiations that led to the establishment of the GATT and the ITO. In this sense, the WTO is rather unique in having at least five decades of negotiations. Resembling the origins of the UN, the origins of the WTO can also be found in the negotiations that began during the last years of World War II. The first articulation of a new vision for a different world after WWII was included in the fourth point of the Atlantic Charter (referred to in the section on the UN) by Roosevelt and Churchill on the:

${ }^{603}$ The most recent to join are Laos in January and Tajikistan in March 2013. 
"enjoyment by all States, great or small, victor or vanquished, of access, on equal terms to the trade and to the raw materials of the world which are needed for their economic prosperity". ${ }^{604}$

Although Cordell Hull was awarded the Nobel Prize for his efforts in establishing the UN, his chief legacy is in the reforming US trade policy which consequently resulted in the establishment of the GATT and of the International Trade Organization (ITO). Being instrumental in the establishment of the UN, Hull also played a key role in changing the US policies on international trade. Having the idea of equality of states in mind, in 1937 he stated:

I have never faltered in my belief that enduring peace and the welfare of nations are indissolubly connected with friendliness, fairness, equality and the maximum practicable degree of freedom in international trade. ${ }^{605}$

Creating an International Trade Organization was an idea discussed during World War $\mathrm{II}^{606}$ and was developed by the United States in 1945 in a document called the "Proposal for Consideration by an International Conference on Trade and Employment". ${ }^{607}$ During the WWII, international cooperation in trade was discussed at the Bretton Woods Conference in 1944. After WWII the ECOSOC Resolution of 1946 lead to the establishment of the Preparatory Committee of the United Nations Conference on Trade and Employment which eventually was instrumental in the drafting of the ITO Charter and of the GATT $1947 .{ }^{608}$ The General Agreement on Tariffs and Trade was agreed during 1946-47 which partially run in parallel with the negotiations on the Havana Charter for an International Trade Organization during 1946-48. ${ }^{609}$ Aside from the US and UK, as will be discussed in the next sections, a number of other states had the possibility to participate in the negotiations for the ITO and the GATT and to a certain degree influ-

604 See the US Department of State: Office of the Historian at: http://history.state.gov/milestones/19371945/BrettonWoods, (visited March, 2013).

605 See Douglas A. Irwin, Petros C. Mavroidis, Alan O. Sykes, The Genesis of the GATT, Cambridge University Press, 2008, pg. 10.

${ }^{606}$ Even since World War I and the League of Nations, efforts to address deteriorating conditions in trade were made. However, humanity unfortunately needed another wakeup call in the form of WW II to move beyond rhetoric. The League of Nations hardly dealt with any economic relations among states except some instances of limited scope. There were attempts in the form of the Geneva Conference of 1927, the London Monetary and Economic Conference of 1933 or with other conferences that were even narrower in scope and membership resulting in failure, see George Bronz, The International Trade Organization Charter, 62 Harv. L. Rev. 1089 (1949), pg. 1090-91.

${ }^{607}$ This proposal was also separately published by the UK stating that it was in agreement with all of its important points. See WTO Analytical Index - Guide to WTO Law and Practice, Sixth Edition, WTO Secretariat, 2012, pg. 3.

${ }^{608}$ For a more detailed chronological order of events see Clair Wilcox, The London Draft of a Charter for an International Trade Organization, 37 Am. Econ. Rev. 529 (1947). The author lists the 1934 Hull Trade Agreement legislation which was expressed also in the Atlantic Charter of 1941, the 1942 Mutual Aid Agreements, the 1944 Bretton Woods, the 1945 Trade Agreements Act renewal, the Proposal for Expansion of World Trade and Employment, the 1946 Resolution of the ECOSOC calling for an International Conference on Trade and setting up the Preparatory Committee and so on, see pg. 529-530.

${ }^{609}$ WTO Analytical Index - Guide to WTO Law and Practice, Sixth Edition, WTO Secretariat, 2012, pg. 3. 
ence their outcome. ${ }^{610}$ A number of states also sent observers in some of the meetings. The Soviet Union was part of the initial preparatory committee established by the ECOSOC however it withdrew from the negotiations and as a result never became a Contracting Party of the GATT.

The following sections in a chronological order discuss the principle of equality of states in the negotiations that eventually led to the establishment of the WTO: the Bretton Woods Conference, the ITO, and the GATT.

\section{A. THE BRETTON WOODS CONFERENCE}

During the summer of 1944, the United Nations Monetary and Financial Conference was held at Bretton Woods in New Hampshire, thus this conference is commonly known as the Bretton Woods Conference. The Bretton Woods Conference produced the so called "Bretton Woods System" which besides the International Monetary Fund and the World Bank also includes the efforts for the establishment of an institution on trade. ${ }^{611}$ Though of course the GATT was not created at Bretton Woods, calls for an International Trade Organization were made at the Bretton Woods Conference and in some ways the WTO eventually became "the missing leg of the Bretton Woods stool" and completed the triad of the Bretton Woods Institutions consisted of the IMF, the World Bank and the WTO. ${ }^{612}$ The Bretton Woods Conference had an impact in initiating negotiations that resulted with the conclusion of the GATT and of the Charter for the ITO. This dimension of the Bretton Woods will be briefly outlined here.

The Bretton Woods Conference was primarily initiated by the US and to a certain degree by the UK. ${ }^{613}$ In addition to the US and the UK, 43 other nations ${ }^{614}$ were present at the Bretton Woods Conference. ${ }^{615}$ With regard to trade, they adopted a resolution according to which they seek:

"to reach agreement, as soon as possible, on ways and means whereby they may best: (1) reduce obstacles to international trade and in other ways promote mutually advantageous international commercial relations... "616

\footnotetext{
${ }^{610}$ For information on the specific participants in these meetings see UN Yearbook 1946/47, Part II, Chapter IX, The International Trade Organization (Proposed), pg. 821-824, available at: http://unyearbook.un.org/1946-47YUN/1946-47_P2_CH9.pdf, (visited March, 2013).

${ }^{611}$ Gerald M. Meier, The Bretton Woods Agreement-Twenty Five Years After, 23 Stan. L. Rev. 235 (1971), pg. 237.

${ }^{612}$ See John H. Jackson The World Trading System: Law and Policy of International Economic Relations, Second Edition, MIT 1997, pg. 32; John H. Jackson, Sovereignty, the WTO and Changing Fundamentals of International Law, Cambridge University Press, 2006, pg. 6.

${ }^{613}$ See Ronald A. Reis, The World Trade Organization (Global Organizations), Chelsea House Publishers, 2009, pg. 26.

${ }^{614}$ For the list of the participating nations see the section on IMF in the next chapter, 382.

${ }^{615}$ Ronald A. Reis, The World Trade Organization (Global Organizations), Chelsea House Publishers, 2009, pg. 41.

${ }^{616}$ John W. Pehle, The Bretton Woods Institutions, 55 Yale L. J. 1127 (1946), pg. 1129.
} 
The Bretton Woods Conference aimed at restoring world trade, free from restrictions and discrimination and to stop the creation of economic blocs conflicting with each other. ${ }^{617}$ Although it was recognized that there is a need for an institution on trade to complement the IMF and the World Bank, Bretton Woods Conference did not deal with this issue in a sufficient manner. ${ }^{618}$ According to Jackson, the reason why the Bretton Woods Conference did not address the problems of trade is due to the fact that the participating states at the conference were primarily represented by the ministries of finance and trade was under the authority of other ministries. ${ }^{619}$ Therefore the US and the UK called for additional negotiations on trade and on the establishment of the ITO. ${ }^{620}$

From the perspective of the principle of equality of states in international organizations, at first sight, there is nothing of importance to note in the Bretton Woods Conference on the establishment of an international organization dealing with trade. However, this may also be the fortunate turn of events for the principle of equality of states in IGOs. The fact is that both IGOs (IMF and World Bank) established at the Bretton Woods Conference adopted a weighted voting system which is based on inequality of voting power between members and as such is not in compliance with the principle of equality of states. Whether the Bretton Woods Conference would have introduced a weighted voting model of decision-making had an international organization dealing with trade been established together with the IMF and the WB, no one can really know for sure. However, as will be seen also in the next chapter (discussing the principle of equality of states in the IMF), the weighted voting system discussed and adopted at the Bretton Woods Conference did not present a "friendly" environment for the principle of equality of states. Based on this, it seems that it is more "likely" than "unlikely" that the result would have been unfavorable for the principle of equality of states if an IGO dealing with trade would have been also established at the Bretton Woods Conference.

\section{B. THE ITO}

The preparatory history of the ITO, including the history of the Havana conference, is important for the application of the principle of equality of states. This is not a surprise, as much of the preparatory history of the ITO is in relation at the same time with the preparatory work of the GATT as well.

The ITO was supposed to supplement the two already established institutions from the Bretton Woods Conference, the IMF and the World Bank. The first draft of the ITO

\footnotetext{
${ }^{617}$ Ibid., pg. 1128 .

${ }^{618}$ Peter Van den Bossche, The Law and Policy of the World Trade Organization: Text, Cases and Materials, Second Edition, Cambridge University Press, 2008, pg. 78. Also see John H. Jackson The World Trading System: Law and Policy of International Economic Relations, Second Edition, MIT, 1997, pg. 36.

${ }^{619}$ John H. Jackson The World Trading System: Law and Policy of International Economic Relations, Second Edition, MIT 1997, pg. 36.

${ }^{620}$ Mary E. Footer, An Institutional and Normative Analysis of the World Trade Organization, Martinus Nijhoff Publishers, 2006, pg. 13.
} 
Charter was produced by the State Department as early as August 1944, and first published in December 1945 based on US and UK discussions. ${ }^{621}$ The United States invited fifteen states to engage in negotiations on the "Proposals for the Expansion of World Trade and Employment” and conclude a multilateral agreement on tariff reduction. On 18 February 1946 the ECOSOC adopted a Resolution on a World Conference on Trade and Employment calling for a Charter on the ITO. ${ }^{622}$ The first meeting of ECOSOC was held in February, 1946 in Paris and was instrumental in appointing the Preparatory Committee of the United Nations Conference on Trade and Employment envisaged to prepare the agenda and a draft convention or charter for an ITO. ${ }^{623}$ The Preparatory Committee was composed of representatives of the following 19 states: Australia, Belgium, Brazil, Canada, Chile, China, Cuba, Czechoslovakia, France, India, Lebanon, Luxembourg, Netherlands, New Zealand, Norway, the Union of South Africa, the U.S.S.R., the UK and the US. ${ }^{624}$

There were two sessions of the Preparatory Committee and a meeting resulting in the conclusion of the final draft Charter which was adopted at the Havana Conference in Cuba. The first session was held in London from October 15 until November 26 of 1946, continued by the meeting held from January 20 until February 25 of 1947 in New York, the second session was during April 10-August of 1947 in Geneva and the Conference of Havana, Cuba from November 1947- March 1948. ${ }^{625}$

In addition to the members of the Preparatory Committee (although the USSR was not present), Colombia, Denmark, Mexico, Peru and Poland were observers in the First and Second Sessions, while Afghanistan, Argentina, Ecuador, Egypt, Greece, Iran, Saudi Arabia, Sweden, Thailand, Turkey, Uruguay, Venezuela and Yugoslavia sent observers to the Second Session. ${ }^{626}$

Months before the first session of the Preparatory Committee, in September 1946, the United States introduced a "Suggested Charter". ${ }^{627}$ In addition, also Brazil submitted a draft Charter and India submitted detailed commentaries to the US draft Charter. ${ }^{628}$

\footnotetext{
${ }^{621}$ Douglas A. Irwin, Petros C. Mavroidis, Alan O. Sykes, The Genesis of the GATT, Cambridge University Press, 2008, pg. 2.

${ }^{622}$ UN ECOSOC Res. 13. UN Doc E22 (1946).

${ }^{623}$ Mary E. Footer, An Institutional and Normative Analysis of the World Trade Organization, Martinus Nijhoff Publishers, 2006, pg. 14, UN Yearbook 1946/47, Part II, Chapter IX, The International Trade Organization (Proposed), pg. 821, available at: http://unyearbook.un.org/1946-47YUN/1946-47_P2_CH9.pdf, (visited March, 2013).

${ }^{624}$ UN Yearbook 1946/47, Part II, Chapter IX, The International Trade Organization (Proposed), pg. 821, available at: http://unyearbook.un.org/1946-47YUN/1946-47_P2_CH9.pdf, (visited March, 2013).

${ }^{625}$ Robert R. Wilson, Proposed ITO Charter, 41 Am. J. Int’l. L. 879 (1947), pg. 879-880. Also see George Bronz, The International Trade Organization Charter, 62 Harv. L. Rev. 1089 (1949), footnote 1.

${ }^{626}$ WTO Analytical Index - Guide to WTO Law and Practice, Sixth Edition, WTO Secretariat, 2012, pg. 4, footnote 1.

${ }^{627}$ Mary E. Footer, An Institutional and Normative Analysis of the World Trade Organization, Martinus Nijhoff Publishers, 2006, pg. 14.

${ }^{628}$ UN Yearbook 1946/47, Part II, Chapter IX, The International Trade Organization (Proposed), pg. 822, available at: http://unyearbook.un.org/1946-47YUN/1946-47_P2_CH9.pdf, (visited March, 2013).
} 


\section{The London Session}

The London session was held from 15 of October- 26 November 1946 at Church House, Westminster and resulted in the so-called "London Report". ${ }^{629}$ This was the first of the preparatory meetings and the first formal meeting where, besides the US and the UK, other countries were invited to participate. ${ }^{630}$ The London session produced a draft Charter of the ITO based on the draft charter suggested and circulated by the US and communicated to the UK Government on December $61945 .{ }^{631}$ It is interesting from the perspective of the principle of equality of states that there where references during the London session about the possibility of using a weighted system of decision-making in the ITO. During the London session the UK proposed for a model of weighted voting to be discussed for the ITO based on the proposition that:

"it was not truly democratic to permit states with a smaller share of international trade to outvote those whose interests were proportionately larger." 632

Such an assertion was almost unanimously rejected as there was general support for the one-state one-vote principle although it was agreed that alternative texts would be provided based on a system of: 1 . equal voting and 2 . weighted voting. ${ }^{633}$

\section{The New York Lake Success Meeting}

In between the first session of London and the second session in Geneva of the Preparatory Committee, there was another meeting held in New York from January 20 to February 25 of 1947.

The New York meeting (usually referred to as a meeting and not as a session, as are the meetings of London and Geneva) was further instrumental in elaborating and editing the London Draft. ${ }^{634}$

On the other hand, the New York meeting was also able to produce a "first full draft of the GATT by drawing on the commercial-policy chapters of the draft ITO chapter". 635

\footnotetext{
${ }^{629}$ WTO Analytical Index - Guide to WTO Law and Practice, Sixth Edition, WTO Secretariat, 2012, pg. 4. ${ }^{630}$ Douglas A. Irwin, Petros C. Mavroidis, Alan O. Sykes, The Genesis of the GATT, Cambridge University Press, 2008, pg. 77. One should also have in mind that some of the "countries" mentioned in fact where Dominions of the UK and not states.

${ }^{631}$ The Proposed International Trade Organization. Havana Conference on Trade and Employment, 1 Int'l. L. Quart. 541 (1947), pg. 541-542.

${ }^{632}$ See Elizabeth McIntyre, Weighted Voting in International Organizations, 8 Int'l. Org. L. Rev. 484 (1954), pg. 489

${ }_{633}$ Ibid.

${ }^{634}$ The Proposed International Trade Organization. Havana Conference on Trade and Employment, 1 Int'l. L. Quart. 541 (1947), pg. 542.

${ }^{635}$ See Douglas A. Irwin, Petros C. Mavroidis, Alan O. Sykes, The Genesis of the GATT, Cambridge University Press, 2008, pg. 80.
} 


\section{The Geneva Session}

The Committee continued its work in its second session from April to November 1947 in Geneva. Eighteen participants were present: Australia, Belgium, Luxembourg, Brazil, Canada, Chile, China, Cuba, Czechoslovakia, France, India, Lebanon, the Netherlands, New Zealand, Norway, the Union of South Africa, the US and the UK. ${ }^{636}$ It is important to state that this was not a meeting of states only, as for example for India and New Zealand statehood was a contentious issue (India became independent in August 1947 in the midst of the Geneva session).

The Geneva Conference was dealing with three issues: first, the preparation of the Charter for ITO; second, the reduction of tariffs and the development of multilateral agreements achieving that aim, and the third, the drafting of "general clauses" for tariff obligations. ${ }^{637}$

The Geneva session produced a Draft Charter which represented thus far the most far reaching and elaborate document ever drafted on the issue which also projected the ITO as a Specialized Agency of the UN. ${ }^{638}$ However, only the GATT was agreed during the Geneva session and the ITO Charter was yet to be agreed during the Havana Conference.

\section{The Havana Conference}

The Havana Conference, which was held from November 21, 1947 and ended in March 1948, resulted with the Havana Charter for the International Trade Organization and also annexed a final act for the establishment of an Interim Commission of the ITO. ${ }^{639}$ Representatives of fifty-three nations signed the ITO Charter. The signatories of the Final Act of the United Nations Conference on Trade and Development producing the ITO Charter were: Afghanistan, Australia, Austria, Belgium, Bolivia, Brazil, Burma, Canada, Ceylon, Chile, China, Colombia, Costa Rica, Cuba, Czechoslovakia, Denmark, Dominican Republic, Ecuador, Egypt, El Salvador, France, Greece, Guatemala, Haiti, India, Indonesia, Iran, Iraq, Ireland, Italy, Lebanon, Liberia, Luxembourg, Mexico, the Netherlands, New Zealand, Nicaragua, Norway, Pakistan, Panama, Peru, Philippines,

\footnotetext{
${ }^{636}$ The Soviet Union though a member of the Preparatory Committee did not participate. See, Robert R. Wilson, Proposed ITO Charter, 41 Am. J. Int’l. L. 879 (1947), pg. 880, footnote 5.

${ }^{637}$ Peter Van den Bossche, The Law and Policy of the World Trade Organization: Text, Cases and Materials, Second Edition, Cambridge University Press, 2008, pg. 78.

${ }^{638}$ The Proposed International Trade Organization. Havana Conference on Trade and Employment, 1 Int'l. L. Quart. 541 (1947), pg. 542.

${ }^{639}$ The following Governments were represented in the Conference: Afghanistan, Australia, Austria, Belgium, Bolivia, Brazil, Burma, Czechoslovakia, Denmark, Dominican Republic, Ecuador, Egypt, El Salvador, France, Greece, Guatemala, Haiti, India, Indonesia, Iran, Iraq, Ireland, Italy, Lebanon, Transjordan, South Africa, UK and GB, Canada, Ceylon, Chile, China, Columbia, Costa Rica, Cuba, Liberia, Luxemburg, Mexico, Netherlands, New Zealand, Nicaragua, Norway, Pakistan, Panama, Peru, Philippines, Portugal, Southern Rhodesia, Sweden, Switzerland, Syria, US, Uruguay, Venezuela, see the Final Act of the United Nations Conference on Trade and Employment. Also see George Bronz, The International Trade Organization Charter, 62 Harv. L. Rev. 1089 (1949), pg. 1090.
} 
Portugal, Southern Rhodesia, Sweden, Switzerland, Syria, Transjordan, the Union of South Africa, UK, US, Uruguay and Venezuela. ${ }^{640}$ Note that the Government of Southern Rhodesia participated in the negotiations and signed the Final act although it was not an independent state but under UK rule. ${ }^{641}$

Although signed by the United States in Havana, the ITO Charter also needed Congressional approval. The president submitted the ITO Charter for approval in 1949. However due to the fact that there was no more "wartime urgency for new institutions", that the Congress was dominated by the Republican Party (the president was a Democrat) as well as for other reasons the Charter was not approved by the Congress. ${ }^{642}$ As no success in adopting the ITO Charter by the US Congress was achieved by 1951, President Truman expressed his intentions not to look for Congressional approval anymore. Without the ratification of the US, the greatest trading nation of the world, "it did not have the chance to die; it was simply stillborn”. ${ }^{643}$ In practice, other nations simply did not have the option to go ahead and establish the ITO without the United States. This situation is similar to the one during the creation of the League of Nations and the refusal by the US Congress to adopt the Covenant. The difference is that then, it was decided to go ahead without the US and now, with the experience of the failure of the League of Nations and the emergence of the US as the greatest superpower after WWII, such an option was not pursued.

Bearing in mind that the ITO could have become the first international organization dealing with trade, it is of interest to discuss the principle of equality of states in the ITO Charter.

\section{THE PRINCIPLE OF EQUALITY OF STATES AND THE HAVANA CHARTER}

The agreed ITO Charter ${ }^{644}$ had 106 Articles, IX chapters and an astonishing 16 annexes ranging from Annex A to P. The ITO was envisaged to have legal personality and enjoy privileges and immunities in the territories of its members. ${ }^{645}$ Article 1 of the ITO Charter on "Purposes and Objectives" defines the aims of the organization (in similar terms as the goals of the WTO), as follows: achieving higher living standards, full

\footnotetext{
${ }^{640}$ See the Final Act of the United Nations Conference on Trade and Employment, Havana, Cuba, 1948, available at the WTO web page at: http://www.wto.org/english/docs_e/legal_e/havana_e.pdf, (visited March, 2013), pg. 5-7.

${ }^{641}$ GATT Analytical Index - Guide to GATT Law and Practice, Sixth Edition, WTO Secretariat, 2012, pg. 1013.

${ }^{642}$ John H. Jackson The World Trading System: Law and Policy of International Economic Relations, Second Edition, MIT, 1997, pg.38.

${ }^{643}$ Stated by Richard Gardner, an American diplomat, see Ronald A. Reis, The World Trade Organization (Global Organizations), Chelsea House Publishers, 2009, pg. 43.

${ }^{644}$ See the Final Act of the United Nations Conference on Trade and Employment, Havana, Cuba, 1948 , available at the WTO web page at: http://www.wto.org/english/docs_e/legal_e/havana_e.pdf, (visited March, 2013).

${ }^{645}$ ITO Charter, Article 89, 90
} 
employment and the goals of Article 55 of the UN Charter on economic and social development. ${ }^{646}$

The ITO Charter had significant references to the principle of equality of states. Article 1, and especially paragraphs 3 and 4 thereof, are relevant to the principle of equality of states. The parties to the ITO Charter, according to Article 1 (3), among others aimed to achieve the following objectives:

"to further enjoyment by all countries, on equal terms, of access to the markets, products and productive facilities which are needed for their economic prosperity and development. ${ }^{, 647}$

This wording was in line with the principle of equality of states as it spoke of nondiscrimination of "all countries" and access on "equal terms". According to Article 1 (4) the objective was also to:

"promote on a reciprocal and mutually advantageous basis the reduction of tariffs and other barriers to trade and the elimination of discriminatory treatment in international commerce". ${ }^{648}$

The ITO Charter made a distinction between original and non-original members and also foresaw the possibility for separate customs territories to join the organization. ${ }^{649}$ Accordingly, any state or separate customs territory invited to the UN Conference on Trade and Employment, accepting the ITO Charter by September 30, 1949, could also acquire such membership. ${ }^{650}$ Besides states and customs territories, the ITO Charter provided that membership rights and obligations may also be extended to: the Free Territory of Trieste, any Trust Territory of the UN and any other UN specially established regime. ${ }^{651}$ In this regard, the ITO membership would have been more heterogeneous than that of the WTO. The ITO, however, did not refer to any international organization as a member or a potential member as is the case with the WTO and the EU.

The Havana Charter also introduced the institutional framework of the ITO according to which the organization would have: a Conference, an Executive Board and a Director-General and Staff. ${ }^{62}$ The Conference representing the plenary organ and the final authority of the ITO was fully compatible with the principle of equality of

\footnotetext{
${ }^{646}$ Robert R. Wilson, Proposed ITO Charter, 41 Am. J. Int'l. L. 879 (1947), pg. 880. Also see The Proposed International Trade Organization. Havana Conference on Trade and Employment, 1 Int'l. L. Quart. 541 (1947), pg. 542.

${ }^{647}$ See ITO Charter, Article 1 (3).

${ }^{648}$ See ITO Charter, Article 1, (3).

${ }^{649}$ See ITO Charter, Article 71, (1-5).

${ }^{650}$ Note that although separate customs territories are invited along states by the UN Conference on Trade and Employment, according to Article 71: 1 (b) of the ITO Charter, it is "the competent Member" which accepts the Charter on behalf of the customs territory.

${ }^{651}$ See ITO Charter, Article 71: 4 (a-c).

${ }^{652}$ See ITO Charter. Article 73,
} 
states. ${ }^{653}$ All ITO members were entitled to representation in the Conference and all, in line with the principle of equality of states, had one vote. ${ }^{654}$

With regard to decision-making, the Conference required majority decisionmaking with equal voting powers. The Executive Board, on the other hand, was envisaged to represent the non-plenary organ with limited membership of only 18 members selected by the Conference. ${ }^{65}$ Other members, not elected in the Executive Board, could have participated in any discussions on matters relevant to that member without the right to vote. ${ }^{656}$ Each member of the Executive Board had one vote and decisions were supposed to be adopted by majority. The Director-General of the ITO is appointed by the Conference based on the recommendation of the Executive Board. ${ }^{657}$

The ITO Charter was in compliance with the principle of equality of states with regard to equality of voting power as all members had one vote. Majority decisionmaking based on such equality of voting power was also in line with the principle of equality of states in the ITO. However, with regard to representation of ITO members, there was a deviation from the principle of equality of states with the limited representation in the Executive Board. Note that the WTO does not provide for such an Executive Board. In addition, the appointment of the Director-General of the ITO as a result of a recommendation of a non-plenary body (the Executive Board) was also not in compliance with the principle of equality of states. As it will be seen in the next sections, from the perspective of the application of the principle of equality of states, it was a fortunate circumstance that the ITO Charter was not approved by the US Congress, as the WTO Agreement does not contain such provisions in deviation from the principle of equality of states.

\section{THE GATT 1947}

The WTO's origins are laid down in the General Agreement on Tariffs and Trade of 1947 or the "GATT" ${ }^{658}$ Therefore, in order to understand the WTO we also need to understand the GATT, its "predecessor". 659

Although the GATT was supposed to be a temporary solution and the ITO a more sustainable one, the end result was that the GATT transformed into a "temporary"

\footnotetext{
${ }^{653}$ See ITO Charter, Article 77 (1) on the powers and duties of the Conference.

${ }^{654}$ See Article 74 on the composition and representation of the Conference and Article 75 on the voting power of the ITO Charter.

${ }^{655}$ See Article 78 (1), the Board was foreseen to be representative of the broad geographical areas having regard for members of chief economic importance based on their shares in the international trade and representatives of different types of economies or degrees of economic development of the members of the organization. Customs unions were also eligible for membership in the Executive Board. See Article 73 (2), (a),(b),(c) of the ITO Charter

${ }^{656}$ ITO Charter, Article 80, (4).

${ }^{657}$ ITO Charter, Article 84.

${ }^{658}$ Peter Van den Bossche, The Law and Policy of the World Trade Organization: Text, Cases and Materials, Second Edition, Cambridge University Press, 2008, pg. 77.

${ }^{659}$ John H. Jackson The World Trading System: Law and Policy of International Economic Relations, Second Edition, MIT, 1997, pg. 31.
} 
solution lasting five decades, while the ITO never came to being. ${ }^{600}$ The importance of the GATT is emphasized in Article XVI of the WTO Agreement, which states that the:

"WTO shall be guided by the decisions, procedures and customary practices followed by the CONTRACTING PARTIES to GATT 1947 and the bodies established in the framework of GATT."

Moreover, Article XVI foresees that to the extent practicable, the GATT Secretariat will become the WTO Secretariat and that the GATT Director-General was to become the WTO Director-General until one was newly appointed ${ }^{662}$ Finally, the WTO Agreement also builds upon the consensus decision-making practices of the GATT. ${ }^{663}$

The history of the GATT begins in December 1945 with the US inviting its wartime allies to negotiate a multilateral agreement for the reduction of tariffs on trade in goods. ${ }^{64}$ The agreement on the GATT was reached during the Geneva session dealing (in addition to the ITO Charter) with multilateral tariff cuts and the general clauses. In the meantime, the US Congress had made it clear to the Geneva negotiators that the GATT could not be accepted as an organization, therefore the draft of the GATT was stripped of the attributes of an international organization by replacing the word "member" with "contracting party". ${ }^{665}$ Although a multilateral agreement, the GATT "successfully 'transform' itself-in a pragmatic and incremental manner-into a de facto international organization”. ${ }^{666}$ It is considered a de facto organization though lacking any form of institutional provisions ${ }^{667}$ and which is even more interesting it "never came into force". ${ }^{668}$ In fact, the GATT treaty was provisionally implemented through the 47 years of application of the Protocol of Provisional Application. ${ }^{669}$ Due to these reasons, the GATT had Contracting Parties and no Members. The status of a Contracting Party was acquired either through accession to the GATT as an "original" Contracting Party by participation in the negotiations for reaching an agreement on the GATT, or through accession. There were 23 original Contracting Parties that participated in the

\footnotetext{
${ }^{660}$ The relation between the GATT Agreement and the ITO Charter was regulated by Article XXIX which stated that the GATT would be suspended as soon as the ITO Charter would come to force, See GATT 1947, Article XXIX, (2-6).

${ }^{661}$ The WTO Agreement, Article XVI: 1.

${ }^{662}$ The WTO Agreement, Article XVI: 1 and XVI: 2.

663 The WTO Agreement, Article IX:1.

${ }^{664}$ Peter Van den Bossche, Werner Zdouc, The Law and Policy of the World Trade Organization: Text, Cases and Materials, Third Edition, Cambridge University Press, 2013, pg. 76.

665 John H. Jackson, Sovereignty, the WTO and Changing Fundamentals of International Law, Cambridge University Press, 2006, pg. 93.

${ }^{666}$ Peter Van den Bossche, Werner Zdouc, The Law and Policy of the World Trade Organization: Text, Cases and Materials, Third Edition, Cambridge University Press, 2013, pg. 78.

${ }^{667}$ Mary E. Footer, An Institutional and Normative Analysis of the World Trade Organization, Martinus Nijhoff Publishers, 2006, pg. 17.

${ }^{668}$ John H. Jackson The World Trading System: Law and Policy of International Economic Relations, Second Edition, MIT, 1997, pg. 36.

${ }^{669}$ John H. Jackson, Sovereignty, the WTO and Changing Fundamentals of International Law, Cambridge University Press, 2006, pg. 82.
} 
negotiations for reaching an agreement on the GATT and acquired such status. ${ }^{670}$ Note that some of the "original" Contracting Parties were not states at the time when they were negotiating the GATT. Such an example is Ceylon gaining independence on February 4 1948, Burma, gaining independence on January 4 1948, and India on August $151947 .{ }^{671}$ The original Contracting Parties did not need to apply for accession to the GATT and no decision on accession by the existing Contracting Parties was needed. All members of the Preparatory Committee for the preparation of the United Nations Conference on Trade and Employment mentioned above ${ }^{672}$ (except for the USSR) became GATT Contracting Parties under the Protocol of Provisional Application. ${ }^{673}$ Almost half of the 23 original Contracting Parties were developing countries. ${ }^{674}$ The remaining Contracting Parties joined the GATT 1947 through accession to the GATT. ${ }^{675}$ The accession to the GATT was regulated by Article XXXIII which stated that:

${ }^{670}$ The following Contracting Parties acquired such status: Commonwealth of Australia, the Kingdom of Belgium, the United States of Brazil, Burma, Canada, Ceylon, the Republic of Chile, the Republic of China, the Republic of Cuba, the Czechoslovak Republic, the French Republic, India, Lebanon, the Grand-Duchy of Luxemburg, the Kingdom of the Netherlands, New Zealand, the Kingdom of Norway, Pakistan, Southern Rhodesia, Syria, the Union of South Africa, the United Kingdom of Great Britain and Northern Ireland, and the United States of America, See the General Agreement on Tariffs and Trade (GATT 1947).

671 See CIA World Factbook at https://www.cia.gov/library/publications/the-world-factbook/index.html, (visited March, 2013).

${ }^{672}$ On the states appointed as members of the Preparatory Committee for the preparation of the United Nations Conference on Trade and Employment, see above, pg. 200.

${ }^{673}$ WTO Analytical Index - Guide to WTO Law and Practice, Sixth Edition, WTO Secretariat, 2012, pg. 4, footnote 1 .

${ }^{674}$ If a system of weighted voting based on the world share of trade would have been adopted, it is interesting to note that the Contracting Parties when GATT entered into force was diverging from: Australia 3.2\%, Belgium-Netherlands-Luxembourg 11.0\%, Brazil 2.8\%, Burma 0.7\%, Canada $7.2 \%$, Ceylon 0.6\%, Chile 0.6\%, China 2.7\%, Cuba 0.9\%, Czechoslovakia 1.4\%, France 9.5\%, India (Pakistan) 3.3\%, New Zealand $1.2 \%$, Norway $1.5 \%$, Southern Rhodesia $0.3 \%$, Syro-Lebanese customs union $0.1 \%$, South Africa $1.7 \%$, United Kingdom 25.9\%, United States 25.4\%. See Douglas A. Irwin, Petros C. Mavroidis, Alan O. Sykes, The Genesis of the GATT, Cambridge University Press, 2008, pg. 120, also see Peter Sutherland et al. The Future of the WTO: Addressing Institutional Challenges in the New Millennium (The Sutherland Report), Geneva: WTO, 2004, pg. 9.

${ }^{675}$ The complete list of the GATT 1947 Contracting Parties includes: Angola, Antigua and Barbuda, Argentina, Australia, Austria, Bahrain, Bangladesh, Barbados, Belgium, Belize, Benin, Bolivia, Botswana, Brazil, Brunei Darussalam, Burkina Faso, Burundi, Cameroon, Canada, Central African Republic, Chad, Chile, Colombia, Congo, Costa Rica, Côte d'Ivoire, Cuba, Cyprus, Czech Republic, Denmark, Djibouti, Dominica, Dominican Republic, Egypt, El Salvador, Fiji, Finland, France, Gabon, The Gambia, Germany, Ghana, Greece, Grenada, Guatemala, Guinea, Guinea Bissau, Guyana, Haiti, Honduras, Hong Kong, Hungary, Iceland, India, Indonesia, Ireland, Israel, Italy, Jamaica, Japan, Kenya Korea, Republic of, Kuwait, Lesotho, Liechtenstein, Luxembourg, Macao, Madagascar, Malawi, Malaysia, Maldives, Mali, Malta, Mauritania, Mauritius, Mexico, Morocco, Mozambique, Myanmar, Namibia, Netherlands, New Zealand, Nicaragua, Niger, Nigeria, Norway, Pakistan, Papua New Guinea, Paraguay, Peru, Philippines, Poland, Portugal, Qatar, Romania, Rwanda, Senegal, Sierra Leone, Singapore, Slovak Republic, Slovenia, Solomon Islands, South Africa, Spain, Sri Lanka, Saint Kitts and Nevis, Saint Lucia, Saint Vincent and the Grenadines, Suriname, Swaziland, Sweden, Switzerland, Tanzania, Thailand, Togo, Trinidad and Tobago, Tunisia, Turkey, Uganda, United Arab Emirates, United Kingdom, United States of America, Uruguay, Venezuela, Yugoslavia, Zaire, Zambia, Zimbabwe. See WTO web page at: http://www.wto.org/english/thewto_e/gattmem_e.htm, (visited March, 2013).

Note that Burma is not listed as a GATT Contracting Party as it changed its name into Myanmar in 1989; neither is Ceylon, having changed its name into Sri Lanka in 1972. On the other hand the Czechoslovak 
"a government not party to this Agreement, or a government acting on behalf of a separate customs territory possessing full autonomy in the conduct of its external commercial relations and of the other matters provided for in this Agreement, may accede to this Agreement, on its own behalf or on behalf of that territory, on terms to be agreed between such government and the CONTRACTING PARTIES. Decisions of the CONTRACTING PARTIES under this paragraph shall be taken by a two-thirds majority." ${ }^{676}$

From the wording of Article XXXIII it is obvious that there is no mention of the notion of a "state" neither of a "country". The reason behind this was to allow for governments possessing less than complete sovereignty to become Contracting Parties. ${ }^{677}$ This provision does not provide for any special procedures regardless if the accession is foreseen for a state or a non-state entity. As a result of the accession to the GATT, the GATT increased the number of its Contracting Parties by a group of nine new Contracting Parties in 1949, four in 1951 and at times individual Contracting Parties adhered to the GATT. ${ }^{678}$ Besides states also separate customs territories were allowed to join the GATT. Hong Kong and Macao were Contracting Parties of the GATT and Chinese Taipei started its application to the GATT and became a member of the WTO. ${ }^{679}$

With regard to the application of the principle of equality of states, it seems important to note that there is a difference between the original GATT Contracting Parties having acquired such status by "only" participating in the negotiations for reaching an agreement on the GATT and the ones that have joined the GATT under the scrutiny of the existing Contracting Parties. The former except for the opportunity to become Contracting Parties automatically through participation in the negotiations, also had the opportunity to discuss and influence the outcome of the agreement (the GATT). It is important to note that this distinction is relevant only with regard to the possibility of becoming a GATT Contracting Party as the GATT did not make any other distinction between its Contracting Parties regardless if they were original or acceded later.

With regard to decision-making, the GATT had adopted majority-decision making. ${ }^{680}$ However, in practice, consensus decision-making was an imperative for much of

Republic is not listed either, as it ceased to exist and was succeeded by the Slovak and the Czech Republic which acceded in 1993 and became GATT Contracting Parties.

${ }^{676}$ GATT 1947, Article XXXIII.

${ }^{677}$ GATT Analytical Index - Guide to GATT Law and Practice, Sixth Edition, WTO Secretariat, 2012, pg. 1017.

${ }^{678}$ See William J. Davey, 'Institutional Framework’ in Patrick F. J. Macrory, Arthur E Appleton, Michael G. Plummer, Editors, The World Trade Organization: Legal, Economic and Political Analysis, Volume I, Springer 2005, pg. 73, also John H. Jackson, Sovereignty, the WTO and Changing Fundamentals of International Law, Cambridge University Press, 2006, pg. 96.

${ }^{679}$ John H. Jackson, Sovereignty, the WTO and Changing Fundamentals of International Law, Cambridge University Press, 2006, pg. 113.

${ }^{680}$ See for example GATT 1947, Article XXV:4 requiring for majority of votes for a decision to be adopted, a two-thirds majority was required by Article XXV:5 for waivers, or according to article XXXIII for accessions to the GATT. 
the GATT. ${ }^{681}$ Other than in cases of accessions and waivers, all decisions in the GATT since 1959 have been taken by consensus. ${ }^{682}$ The practice of consensus decision-making was not based on the text of the GATT, as the treaty did not provide for consensus decision-making process in its text. With regard to voting power, in line with the principle of equality of states, each GATT Contracting Party was entitled to one vote. ${ }^{633}$ As discussed in Chapter III, majority decision-making based on equality of votes is in compliance with the principle of equality of states. Also, the consensus decision-making adopted in practice by the GATT was in line with the principle of equality of states.

From 1948 the GATT developed through rounds of negotiations. The Uruguay Round from 1986-1994 was the most important one as it resulted with an agreement on establishing the World Trade Organization. The Uruguay Round negotiations were the largest ever trade negotiations and were fostered by the European Union and the United States. ${ }^{684}$ Their aim, at least in the beginning, was not the creation of an international organization dealing with trade. The US and most developing countries were not in favor of the idea due to a number of factors, inter alia the "reluctance of major trading nations to give in to voting equality". ${ }^{685}$ Only in 1990, Renato Ruggiero, the Italian Minister of Trade brought up the idea for an international organization for trade and Canada proposed that it should be called the "World Trade Organization" while the European Community's suggestion was that it should be called the "Multilateral Trade Organization”. ${ }^{686}$ In 1991, the EC, Canada and Mexico made a proposal which after the negotiations resulted in the draft Agreement Establishing the Multilateral Trade Organization. The United States finally agreed to support the new international organization dealing with trade, but not without conditioning its participation upon the request for the name of the organization to be called (as was the initial Canadian suggestion) the World Trade Organization. The Final Act of the Uruguay Round was signed by 111 countries consisting mostly of developing countries. ${ }^{687}$ The metamorphosis from GATT to the WTO was not based on a theoretical model but on practical needs and concerns. ${ }^{688}$

${ }^{681}$ John H. Jackson, Sovereignty, the WTO and Changing Fundamentals of International Law, Cambridge University Press, 2006, pg. 108, 112.

${ }^{682}$ Thomas Cottier, Satoko Takenoshita, 'Decision-Making and the Balance of Powers in WTO Negotiations: Towards Supplementary Weighted Voting', in Stefan Griller, Editor, At the Crossroads: The World Trading System and the Doha Round, Springer, 2008, pg. 187.

${ }^{683}$ GATT 1947, Article XXV:3.

${ }^{684}$ John H. Jackson, Sovereignty, the WTO and Changing Fundamentals of International Law, Cambridge University Press, 2006, pg. 5.

${ }^{685}$ See Peter Van den Bossche, The Law and Policy of the World Trade Organization: Text, Cases and Materials, Second Edition, Cambridge University Press, 2008, pg. 82-84.

${ }^{686}$ See Peter Van den Bossche, The Law and Policy of the World Trade Organization: Text, Cases and Materials, Second Edition, Cambridge University Press, 2008, pg. 82-84.

687 Gilbert R. Winham, 'An Interpretative History of the Uruguay Round Negotiations' in Patrick F. J. Macrory, Arthur E Appleton, Michael G. Plummer, Editors, The World Trade Organization: Legal, Economic and Political Analysis, Volume I, Springer 2005, pg. 5.

${ }^{688}$ Mitsuo Matsushita, Thomas J. Schoenbaum, Petros C. Mavroidis, The World Trade Organization: Law, Practice and Policy, Oxford University Press, 2006, pg. 908. 
In regard to the advancement of multilateralism, it is considered that the foundation of the WTO was the most dramatic development since the 1940s. ${ }^{689}$

\section{ORIGINAL MEMBERS AND THE APPLICATION OF THE PRINCIPLE OF EQUALITY OF STATES IN THE WTO}

Article XI of the WTO Agreement deals with original membership of the WTO, it states:

the contracting parties to GATT 1947 as of the date of entry into force of this Agreement, and the European Communities, which accept this Agreement and the Multilateral Trade Agreements and for which Schedules of Concessions and Commitments are annexed to GATT 1994 and for which Schedules of Specific Commitments are annexed to GATS shall become original Members of the WTO. ${ }^{690}$

Therefore, in order to become a WTO original member, the first condition was to be a GATT 1947 Contracting Party, second, to accept the WTO Agreement and the Multilateral Trade Agreements and third, to have a Schedule of Concessions and Commitments annexed to GATT 1994 and a Schedule of Specific Commitments annexed to GATS. The first condition is the status of a Contracting Party of the GATT as a "prerequisite" to become a WTO original member. As discussed in the previous section, there were Contracting Parties that acquired such status only by participating in the negotiations for reaching and Agreement on the GATT and others that acquired such status through accession to the GATT. From the existing GATT Contracting Parties, Yugoslavia ${ }^{691}$ did not participate in the Uruguay Round. In addition, five Contracting Parties (United Arab Emirates, Grenada, Qatar, Papua New Guinea and St. Kitts \& Nevis) did not complete the negotiations on schedules on time. These five Contracting Parties acceded to the World Trade Organization on a fast track. ${ }^{692}$ Eventually, the WTO had 128 original

\footnotetext{
${ }^{689}$ Peter Sutherland et al. The Future of the WTO: Addressing Institutional Challenges in the New Millennium (The Sutherland Report), Geneva: WTO, 2004, pg. 9, 79.

${ }^{690}$ WTO Agreement, Article XI:1. Furthermore, Article XI:2 of the WTO Agreement having due regard to the position of the least-developed countries (recognized as such by the UN) states that they will only be required to undertake commitments and concessions to the extent consistent with their individual development, financial and trade needs or their administrative and institutional capabilities.

${ }^{691}$ After the dissolution of the FR of Yugoslavia, the Council on 19 June 1992 decided that the representative of Yugoslavia should not participate in the business of the Council. On 16-17 June 1993, in light of the Resolution 47/1 of GA of the UN, the Council decided that the Federal Republic of Yugoslavia (Serbia and Montenegro) cannot continue the Contracting Party status and that it should apply for accession to the GATT. Participation in the Council and in other bodies thus was no longer possible. See GATT Analytical Index Guide to GATT Law and Practice, Sixth Edition, WTO Secretariat, 2012, pg. 1014. In the meantime, the succeeding states of Yugoslavia such as Slovenia, Croatia, Macedonia and Montenegro joined the WTO. Bosnia and Herzegovina and Serbia have started the accession process while Kosovo is yet to start.

${ }^{692}$ William J. Davey, 'Institutional Framework' in Patrick F. J. Macrory, Arthur E Appleton, Michael G. Plummer, Editors, The World Trade Organization: Legal, Economic and Political Analysis, Volume I, Springer 2005, pg. 74.
} 
members accounting for about $66 \%$ of the world population and $85.85 \%$ of the total world trade. ${ }^{693}$

The second condition, to accept the WTO Agreement and the Multilateral Trade Agreements, is in line with the principle of equality of states as it is a condition that applies to all potential WTO Members equally.

The third condition, to have negotiated a Schedule of Concessions and Commitments is of interest to the principle of equality of states, especially in comparison to the Schedules of Concession and Commitments between the original WTO Members and the ones joining through the WTO accession process. Therefore, this will be discussed in the next section dealing with WTO accession.

\section{ACCESSION TO THE WTO}

The accession process to the WTO or the accession to the GATT has always been high on the agenda. The reason for the progressive interest in acceding to the World Trade Organization lies in the mutual benefits to the acceding members and to the WTO as well. The WTO strives for universality in world trade through the accession process and the acceding governments strive to benefit from joining the multilateral trading system.

As of March 2013, 55 countries have either acquired WTO membership or are in the process of doing so through the accession process. Accession was completed by 31 countries: Albania, Armenia, Bulgaria, Cambodia, Cape Verde, China, Croatia, Ecuador, Estonia, FYR Macedonia, Georgia, Jordan, Kyrgyz Republic, Lao People’s Republic, Latvia, Lithuania, Moldova, Mongolia, Montenegro, Nepal, Oman, Panama, Russian Federation, Samoa, Saudi Arabia, Chinese Taipei, Tajikistan, Tonga, Ukraine, Vanuatu and Viet Nam. Another 24 countries are currently going through the accession processes which together with the existing members account to almost absolute universality of the world economy. ${ }^{694}$ Although dozens of accessions have taken, or are taking place, the accession process was (and to a certain extent still is) a process not very well understood due to its complexity and lack of transparency. If one point is clear so far, it is the fact that the accession process to WTO is not easy at all. On the contrary, it is complicated, long lasting, demanding, reform oriented and may cause hardship to the economy and problems to the political elites. For example Russia was only able to become a member in 2012 after the longest accession process in the history of the WTO, lasting 18 years; it took China around 16 years, and Algeria is negotiating since

\footnotetext{
${ }^{693}$ Peter John Williams, A Handbook on Accession to the WTO, A WTO Secretariat Publication, Cambridge University Press, 2008, pg. 10, and the Annex 1 table at pg. 133-137 for more detailed information including the differences between the original members and the acceding ones.

${ }^{694}$ For the Summary Table of Ongoing Accessions see the WTO Web Page, at http://www.wto.org/english/thewto_e/acc_e/status_e.htm, (visited March 2013). The countries in the accession process to the WTO include: Algeria, Belarus, Sudan, Uzbekistan, Seychelles, Kazakhstan, Azerbaijan, Andorra, Lebanese Republic, Bosnia Herzegovina, Bhutan, Yemen, Bahamas, Syria, Ethiopia, Libya, Iraq, Afghanistan, Serbia, Iran, Sao Tomé and Principe, Comoros, Equatorial Guinea, Liberia. Out of these countries Algeria applied in 1987 and the most recent applications are as of 2007
} 
1987 and has yet to become a member. Each accession is unique and complex and in the process, no precedent is recognized. This makes the task of identifying patterns and exceptions in the accession proves very difficult and challenging and yet very crucial.

The following sections will address the substantive and procedural law on accession in light of the principle of equality of states.

\subsection{SUBSTANTIVE LAW ON ACCESSION}

Paragraph 1 of Article XII of the WTO Agreement is the most relevant substantive law requirement for accession to the WTO. It states:

"Any State or separate customs territory possessing full autonomy in the conduct of its external commercial relations and of the other matters provided for in this Agreement and the Multilateral Trade Agreements may accede to this Agreement, on terms to be agreed between it and the WTO. Such accession shall apply to this Agreement and the Multilateral Trade Agreements annexed thereto. "695

Although this provision does not provide too much detail, it certainly sets out the main framework on accession. If analyzed, paragraph 1 of Article XII sets three conditions for membership: 1 . only states and customs territories can join, 2. the applicants accede to the agreement only on terms to be agreed, and 3. the accession applies to the whole body of the Multilateral Agreements which are considered as a single undertaking.

With regard to the first condition, that the applicant should be a state or a customs territory, the issue was reviewed in the previous sections and there is no need for repetition here as the arguments apply in this case as well. However, what is not covered is the case of the European Union as a member. Having an international organization as a member does not reflect the position that the WTO is composed of only states and customs territories. This is not reflected in Article XII of the WTO Agreement, dealing with the accession of potential members to the WTO, and foresees the possibility for membership only for two categories of subjects: states and customs territories. ${ }^{696}$ However, this provision does not incorporate the membership of the only international organization in the WTO, the European Union. The membership of the EU was a onetime situation exclusively provided by Article XI which is not a possibility for any other international organization. ${ }^{697}$ In fact the EU membership is of a specific nature because it was the European Communities that was eligible for original membership of the WTO, and thus Article XII does not apply to this case.

\footnotetext{
${ }^{695}$ WTO Agreement, Article XII: 1.

${ }^{696}$ The WTO Agreement, Article XII.

${ }^{697}$ Article XI specifically names the European Communities as a WTO original member to be, thus excluding such a possibility for other international organizations. It states "The contracting parties to GATT 1947 as of the date of entry into force of this Agreement, and the European Communities, which accept this Agreement and the Multilateral Trade Agreements and for which Schedules of Concessions and Commitments are annexed to GATT 1994 and for which Schedules of Specific Commitments are annexed to GATS shall become original Members of the WTO.”
} 
The second condition, regarding the terms agreed relates closely to the work of the Working Party (WP) and is more relevant to the principle of equality of states. The Working Party is established by the General Council and it is responsible for all matters of accession including the preparation of the final Report of the Working Party. In the WP on the one side is the applicant and on the other the WTO Members interested in participating in the WP. Although membership in the Working Party is open for all WTO Members at any stage, in practice however, only a number of WTO Members participate. The largest Working Party was the one on China, including 62 WTO Members (EC and its Member States counted as one) and the smallest one on Tonga was composed of 17 WTO Members. ${ }^{698}$ The limited participation of WTO Members as WP Members is due to the limited resources that a number of WTO Members have which prevents them to participate. After being established, the Working Party examines the commercial policies of the applicant based on the Memorandum provided by the applicant, other documents required or issues raised in the Working Party. This enables the WTO and its members to receive sufficient information on the applicants' trade regime. When the Working Party completes its review, it often asks the WTO Secretariat to prepare a Factual Summary of Points Raised, which forms the basis of the Working Party Report. The second important aspect of the work of the WP relates to the negotiations between the applicant and the WTO Members which cover a wide range of issues: the trade rules, tariff concessions, agricultural support and export subsidies, market access commitments. Commitments on rules are discussed multilaterally in the Working Party, agricultural commitments and commitments on export subsidies are discussed and negotiated plurilaterally, while customs tariffs and specific commitments on services are discussed bilaterally within Working Party members. ${ }^{699}$ With the end of the negotiations, the Working Party sends the Report to the General Council or to the Ministerial Conference for adoption. All data necessary for accession is based on the documentation introduced in the: Memorandum of the Foreign Trade Regime; Factual Summary of Points Raised; the Working Party draft Report; and the Draft Accession Package (with annexed draft Schedules of goods and services negotiated). ${ }^{700}$

With regard to the terms to be agreed in the Working Party there are some aspects that create situations of inequality in the accession process. This primarily relates to the inequality between the applicant and the WTO Members in something that is seen only as a one-way process. Namely, the WTO members review the trade policies of the applicant, they act as the judge/jury and the market access commitments negotiated between the applicant and the existing members are not reciprocal. ${ }^{701}$ The applicant is

\footnotetext{
698 See Peter John Williams, A Handbook on Accession to the WTO, A WTO Secretariat Publication, Cambridge University Press, 2008, pg. 30-31, footnote 24 and 25.

${ }^{699}$ Ibid., pg. 2-3, 33.

${ }^{700}$ See Technical note on the accession process, note by the Secretariat: state of play and information on current accessions, WT/ACC/11/Rev.10, 28 February 2012.

${ }^{701}$ Roman Grynberg, Manleen Dugal and Mohammad A Razzaque, An Evaluation of the Terms of Accession to the World Trade Organization, A Comparative Assessment of Services and Goods Sector Commitments by WTO Members and Acceding Countries, Economic Paper 73, Commonwealth Secretariat, 2006, pg. ix.
} 
not in such a position, as the discussion is not about mutual market access but a one way road, applicable only towards the applicant. The fact that the members of the Working Party or WTO Members involved in the multilateral, plurilateral and especially bilateral negotiations are able to block any decision on accession gives them extraordinary powers over the applicant. WTO Members negotiate market commitments with the applicant, while knowing that without the approval of WTO Members, no accession can take place. Applicants have been required to take WTO-plus commitments such as the examples of the commitments to join the Civil Aircraft Agreement and export subsidies in agriculture to be reduced to zero. ${ }^{702}$ For example, the Working Party sought a commitment from the Kyrgyz Republic that at the time of accession it will adhere to the WTO Agreement on Trade in Civil Aircraft. ${ }^{703}$

The general logic is that the acceding countries should be able to bind tariffs in similar average values as the existing WTO members on a similar stage of economic development. ${ }^{704}$ However, there are arguments that there are significant differences between the existing WTO Members and acceding countries in the commitments undertaken in the goods and services sectors. ${ }^{705}$

The third condition for accession, namely that accession applies to the whole body of the Multilateral Agreements which are considered as a single undertaking means that all applicants must accept the whole body of the Multilateral Agreements and that this condition is not negotiable.

\subsection{PROCEDURAL LAW ON ACCESSION}

Article XII provides for the most relevant provision on the procedural law of WTO accession. It states:

\footnotetext{
${ }^{702}$ Peter John Williams, A Handbook on Accession to the WTO, A WTO Secretariat Publication, Cambridge University Press, 2008, pg. 50-51.

${ }^{703}$ The Kyrgyz Republic stated that it would consider joining the Plurilateral Trade Agreement on Trade in Civil Aircraft from 1 January 1999. "The Working Party took note of this commitment.” See the Report of the Working Party on the Accession of the Kyrgyz Republic, WT/ACC/KGZ/26, 31 July 1998, p. 121-122.

${ }^{704}$ Rolf J. Langhammer and Matthias Lücke, WTO Accession Issues, Kiel Institute of World Economics, Working Paper No. 95, February 1999, pg. 10.

${ }^{705}$ For example, according to one publication comparing the difference between 20 members having acceded to the WTO and existing members on average in the service sector the ratio between the commitments undertaken by WTO members and the acceding countries is as follows: at the aggregate, from the twelve sectors, the WTO members have undertaken some type of commitment in six sectors while acceding countries in eleven, at the 2-digit level the WTO Members have undertaken commitments in 14 sectors, acceding countries in 36, and at the most disaggregated level the difference is 42 for the WTO members against 100 for acceding countries. In the goods sector, all acceding countries have virtually bound all their tariff lines, with an average bound rate of 11 percent compared to a large number of WTO Members having not bound all tariff lines and having an average bound rate of 43 percent (for industrial and agricultural goods together). For example, had Albania, Lithuania, Kyrgyz Republic and Georgia been original members, they would have at least $15 \%$ lower commitments in comparison to the ones they undertook during accession. See Roman Grynberg, Manleen Dugal and Mohammad A Razzaque, An Evaluation of the Terms of Accession to the World Trade Organization, A Comparative Assessment of Services and Goods Sector Commitments by WTO Members and Acceding Countries, Economic Paper 73, Commonwealth Secretariat, 2006, pg. 51-53.
} 
"Decisions on accession shall be taken by the Ministerial Conference. The Ministerial Conference shall approve the agreement on the terms of accession by a two-thirds majority of the Members of the WTO.,"706

After the completion of the work of the Working Party, it is up to the Ministerial Conference or in between the Ministerial Conferences to the General Council to decide on the accession of the applicant. Article XII requires a two- thirds majority for a decision on accession to be adopted, although in practice decisions on accessions have been adopted by consensus. Having in mind that all WTO members have equal voting powers (EU has 27 votes-as of July 2013 will have 28 votes), majority decision-making in accession to the WTO is in compliance with the principle of equality of states. Also, the practice of consensus decision-making in WTO accessions is in line with the principle of equality of states.

The fact that all decisions on accessions are made by the Ministerial Council or the General Council (where all members are represented and have equal voting power) is in line with the principle of equality of states regardless whether the decision is adopted by a majority vote or consensus decision-making.

\subsection{ACCESSION OF LEAST DEVELOPED COUNTRIES TO THE WTO}

The WTO foresees special rules for the accession of Least Developed Countries. In order to assist the Least Developed countries in the accession process to the WTO, a special Guideline for the accession of Least-Developed Countries was developed. ${ }^{707}$ The Guideline foresees accelerated and simplified accession for LDC's, and restraint in seeking concessions and commitments on goods and services having in mind the levels of commitments undertaken by the existing WTO LDC's. ${ }^{708}$ This makes an interesting link between the existing LDC's members of the WTO and the acceding ones in terms of commitments undertaken. Such a basis for comparison between the levels of commitments undertaken by the original WTO Members and the acceding ones (as between LDC's) does not exist in the WTO. This is in line with the principle of equality of states and it is interesting that there is no analogy in the application of such a rule for all accessions and WTO members.

The Guideline also states that accession to Plurilateral Trade Agreements or participation in optional initiatives on sectoral market access is not a precondition for accession. According to WTO rules, accession to the Plurilateral Trade Agreements is not a precondition for accession to any applicant, and thus for LDC's as well. Therefore such a provision in the guidelines is actually a restatement of that rule.

\footnotetext{
${ }^{706}$ WTO Agreement, Article XII: 2.

${ }^{707}$ Accession of Least-Developed Countries, WTO document WT/L/508, of 20 January 2003.

${ }^{708}$ The number of meetings of the Working Party on accessions of LDC's has been kept to a minimum, reducing meetings in Geneva and conduct bilateral meetings on market access in the capitals of the applicant, see Peter John Williams, A Handbook on Accession to the WTO, A WTO Secretariat Publication, Cambridge University Press, 2008, pg. 38.
} 
Moreover, the Sub-Committee on LDC's made a recommendation to the General Council to further strengthen, streamline and operationalize the 2002 LDC accession guidelines. The recommendation was formally approved by the General Council on 25 July 2012 to enable LDC's to negotiate more quickly and easily to obtain membership of the WTO. ${ }^{709}$ The goal is to develop benchmarks on goods and services based on the level of commitments of the existing LDC's Members, more transparency in the accession negotiations, application of special and differential treatment, additional transition periods when possible and additional technical assistance.

As mentioned, the majority of LDC's (34 out of 49 states) are WTO members. However, the following 15 LDC's are not yet members of the WTO: Afghanistan, Bhutan, Comoros, Equatorial Guinea, Eritrea, Ethiopia, Kiribati, Liberia, Sao Tome and Principe, Somalia, South Sudan, Sudan Timor-Leste, Tuvalu, and Yemen. The following LDC's have started the accession process: Afghanistan, Bhutan, Comoros, Equatorial Guinea, Ethiopia, Liberia, Sao Tome and Principe, Sudan and Yemen, while Eritrea, Kiribati, Somalia, South Sudan, Timor-Leste, and Tuvalu have neither joined the WTO nor applied for membership. ${ }^{710}$ These special rules for LDC's may prove to be essential for the accessions of the remaining LDC's to the WTO. They are in compliance with the principle of equality of states as they represent affirmative type of actions and try to address some of the material inequalities between WTO members.

\section{ACQUISITION OF MEMBERSHIP IN THE WTO AND THE PRINCIPLE OF EQUALITY OF STATES}

Acquisition of membership in the WTO has a number of implications for the principle of equality of states. Participation in the negotiations for the establishment of the ITO which paralleled the negotiations for the GATT were conducted under the UN framework at times where the Axis powers were not invited to participate while USSR although a member of the Preparatory Committee did not choose to participate. If the ITO would have come to being, the non-plenary organ in its institutional structure would have represented a deviation from the principle of equality of states.

The states participating in the negotiations on the GATT became "original” GATT Contracting Parties. As discussed, out of the original 23 Contracting Parties some were not independent states at the time. Regardless of this fact, they had the opportunity to influence the GATT and the ITO Charter and become GATT Contracting Parties. All the other GATT Contracting Parties had to go through the GATT accession process which was conditioned by a decision of the existing Contracting Parties. The GATT Contracting Parties also had the opportunity to participate in the Uruguay Round and

${ }^{709}$ See Addendum to the 2002 LDC Accession Guidelines, WT/COMTD/LDC/21, 6 July 2012, also WTO web site at http://wto.org/english/news_e/news12_e/gc_25jul12_e.htm (visited March 2013).

${ }^{710}$ Based on the list provided by the WTO on Accessions at WTO official web site at: http://www.wto.org/english/thewto_e/acc_e/acc_e.htm, and the LDC Group website at: http://www.ldcgroups.org/history_en.php, (visited March, 2013). Note that for the moment the LDC group website does not note that South Sudan as ab LDC has yet not applied for WTO accession. 
influence the establishment of the World Trade Organization. Moreover, they had the opportunity to become original WTO Members and take fewer commitments compared to the WTO Members joining the WTO through the accession process.

The position of the applicant with regard to the existing WTO Members creates situations of inequality in the accession process. The fact that the members of the Working Party or WTO Members involved in the multilateral, plurilateral and especially bilateral negotiations are able to block any decision on accession gives them extraordinary powers over the applicant. The WTO members review the trade policies of the applicant, they act as the judge/jury and the market access commitments negotiated between the applicant and the existing members. The applicant is not in such a position, as the discussion is not about mutual market access but a one way round, applicable only towards the applicant. WTO Members negotiate market commitments with the applicant, while knowing that without the approval of WTO Members, no accession can take place. The fact that the accession process, results in significant differences between the rights and obligations of members may be observed as a deviation from the principle of equality of states. Moreover, having in mind that the law on accession has remained the same there is no legal basis to make accession processes harder and the terms agreed harsher for the new applicants.

Majority decision-making on accession of new members based on equality of voting powers and representation is in compliance with the principle of equality of states. Also the practice of consensus decision-making in accessions to the WTO is also in line with the principle of equality of states as it provides for equality between all WTO Members in the decision-making process.

\section{DECISION-MAKING}

The institutional structure of the WTO includes around 70 bodies, permanent and ad hoc. At the highest level is the Ministerial Conference, followed at the second level by the General Council (acting at the same time also as the Dispute Settlement Body and the Trade Policy Review Body), at the lower level are the specialized councils, committees, working groups and working parties as well as quasi-judicial and other nonpolitical bodies, and a WTO Secretariat. ${ }^{711}$

In light of the principle of equality of states it is important to review the following aspects of decision-making: representation, voting power, majority and consensus decision-making. In all of these aspects, the WTO is in compliance with the principle of equality of states. Regarding representation, all WTO members may participate in all the councils, committees and other bodies. ${ }^{712}$ Such a right belongs to all members

\footnotetext{
${ }^{711}$ Peter Van den Bossche, Werner Zdouc, The Law and Policy of the World Trade Organization: Text, Cases and Materials, Third Edition, Cambridge University Press, 2013, pg. 121.

712 There are some examples of limited membership which occur in the Appellate Body, the Dispute Settlement panels, Textiles Monitoring Body and the plurilateral committees where participation is limited, see The Agreement Establishing the WTO, interpretation given by the WTO at http://www.wto.org/english/res_e/-
} 
regardless of power and size. However, the difficulty of equal representation in practice is that there are numerous ongoing meetings in the WTO and not all members are able to participate. For example, there were around 1000 formal and informal meetings in 2001 compared to around 500 formal and informal meetings in WTO bodies in 2012. ${ }^{713}$ Therefore, having a permanent mission in Geneva is very important for all WTO Members in order to participate actively in the everyday functioning of the organization, particularly having in mind that in principle all WTO bodies are open to all WTO Members. Most of the WTO Members have permanent representatives and it is increasingly common for them to have separate missions dealing exclusively with WTO matters. ${ }^{714}$ However, only around one third of the LDC's have permanent offices in Geneva, and they besides the WTO cover all UN activities as well. ${ }^{715}$ Similarly, at one time, even 18 WTO members from Africa did not have representation at WTO headquarters in Geneva. ${ }^{716}$ Financing is lacking for senior officials, especially in regard to developing countries to be in Geneva more frequently and it is exactly they who need such exposure ("If poorer nations are to make the best of their WTO membership they must be fully and regularly present in Geneva, especially their senior officials)". ${ }^{717}$ Very often the lack of resources is disabling to states to have "equal capacity for rights" provided by WTO law. Another difficulty is that at times the most powerful WTO Members also resort to a practice of decision-making within a limited group of members such as the well-known "green room" discussions. ${ }^{718}$ Such practices of decisionmaking became more and more unpopular as membership in the WTO continued to grow. The green room in the early 70s with its 35 seats held almost half of the membership of the organizations. It was like an exclusive gentlemen's club of privileged members:

booksp_e/analytic_index_e/wto_agree_01_e.htm\#fnt5, (visited March 2013). Having in mind that the Textiles Monitoring Body is no longer operational as of 2005, and that Plurilateral Committees are based on the Plurilateral Agreements not agreed by all, the Dispute Settlement Body and (not mentioned above) the Secretariat will be reviewed in light of the principle of equality of states.

${ }^{713}$ Peter Van den Bossche, The Law and Policy of the World Trade Organization: Text, Cases and Materials, Second Edition, Cambridge University Press, 2008, pg. 117, Peter Van den Bossche, Werner Zdouc, The Law and Policy of the World Trade Organization: Text, Cases and Materials, Third Edition, Cambridge University Press, 2013, pg. 120.

${ }^{714}$ William J. Davey, 'Institutional Framework’ in Patrick F. J. Macrory, Arthur E Appleton, Michael G. Plummer, Editors, The World Trade Organization: Legal, Economic and Political Analysis, Volume I, Springer 2005, pg. 63-64.

${ }^{715}$ Within the negotiations to have Geneva as the WTO headquarters, the Swiss government has offered subsidized office space for LDC's and a number of WTO Members provide for financial assistance for LDC officials to attend Ministerial Conferences, see World Trade Organization, Understanding the WTO, Fifth edition, published by the WTO, 2011, pg. 95.

${ }^{716}$ Michael Byers, Vikram Raghavan, Manuel Becerra-Ramirez, Voices from the Outside: Sovereign Equality, International Law and the Balance of Power, ASIL Proceedings, 2005, pg. 53.

${ }^{717}$ Peter Sutherland et al. The Future of the WTO: Addressing Institutional Challenges in the New Millennium (The Sutherland Report), Geneva: WTO, 2004, pg. 70.

${ }^{718}$ John H. Jackson, Sovereignty, the WTO and Changing Fundamentals of International Law, Cambridge University Press, 2006, pg. 102-103. 
"with its American colonial-style furniture and its portrait hanging on beige walls....people talked, drank and smoked freely for hours on end...Now drinking anything than water its prohibited and it is a non smoking area open to all, whether they have been asked to come or not." $" 119$

A similar practice was the "grouping of the Quad", composed of the former four largest trading entities (the EC, the US, Japan and Canada) which is now replaced by the G-5 (EU, US, India, Brazil and China). ${ }^{720}$ It is no surprise that transparency of the WTO, or better stated, the lack of it, is also one of the main areas of criticism of the work of the WTO, and the organization must continue its transformation from a culture "of secrecy and opaqueness to openness and transparency". ${ }^{721}$

In regard to voting power, the WTO is in line with the principle of equality of states. Unlike the IMF, the WTO does not have weighted voting and each member has one vote. There is neither formal veto power as in the UN Security Council nor actual veto power as is the case for certain instances with the position of the United States in the IMF. The WTO stands in stark contrast as an international economic organization. ${ }^{722}$

With regard to decision-making, the WTO Agreement foresees decision-making based on consensus and for certain matters by majority voting. In practice, the WTO has excluded voting in its decision-making by using consensus decision-making. ${ }^{723}$ To establish consensus on a matter means that no member is actively opposing a decision, which in turn means that it amounts to a veto power for any member regardless how insignificant it may be in trade. ${ }^{724}$ There is no point in having a vote that would:

"create obligations that large and small sovereign states will not implement, and equally pointless to force countries to dissimulate about their tactical or substantive reasons for withholding consensus, reasons, its trading partners will usually know without being told". ${ }^{725}$

Usually the task to find consensus is carried by the Chair of the WTO body, who can draw from a range of techniques varying from open-ended discussions with all members, and up to one-on-one "confessionals" with ambassadors. ${ }^{726}$ Consensus is the way

\footnotetext{
${ }^{719}$ Yves Schemeil 'Consensus making within the World Trade Organization and the World Meteorological Organization' in Bob Reinalda and Bertjan Verbeek, Editors, Decision-making within International Organizations, Edward Elgar Publishing Limited, 2004, pg. 85.

${ }^{720}$ Peter Van den Bossche, Werner Zdouc, The Law and Policy of the World Trade Organization: Text, Cases and Materials, Third Edition, Cambridge University Press, 2013, pg. 108.

${ }_{721}$ Mitsuo Matsushita, Thomas J. Schoenbaum, Petros C. Mavroidis, The World Trade Organization: Law, Practice and Policy, Oxford University Press, 2006, pg. 15-16, 927.

${ }^{722}$ Mary E. Footer, An Institutional and Normative Analysis of the World Trade Organization, Martinus Nijhoff Publishers, 2006, pg. 28.

${ }^{723}$ Peter Sutherland et al. The Future of the WTO: Addressing Institutional Challenges in the New Millennium (The Sutherland Report), Geneva: WTO, 2004, pg. 63.

${ }_{724}$ Ibid.

${ }^{725}$ Robert Wolfe, Decision-Making and Transparency in the "Medieval” WTO: Does the Sutherland Report Have the Right Prescription, 8 J. Int'l. Econ. L. 631 (2005), pg. 635.

${ }^{726}$ Ibid., pg. 637.
} 
for the poorest and the smallest not to be overridden by the great powers, and for the last five decades it has been the cornerstone of the WTO, equaling to the procedural MFN treatment. ${ }^{727}$ According to the former Director-General of the WTO, the:

"consensus decision-making gives all members-rich and poor, big and small, developed and developing- 'ownership' of the system: its decisions, its rules, its rights and its obligations. The effectiveness of the WTO depends fundamentally on its legitimacy, on the willingness of its member governments to abide by its rules and rulings. ${ }^{, 728}$

Consensus decision-making in the Sutherland Reports is referred to as the "safety net" for every WTO member to influence and even block decisions in the WTO. ${ }^{729}$ Jackson seems actually to regard consensual decision-making as one of the ways out of the danger of the majorities of small and weak countries when each has one vote. He states:

"one approach taken in some international institutions to help offset the risk of "unreal recognition of power" involved in one-nation one vote majority systems is to demand use of a "consensus approach" that allows any party to veto a proposed measure. This has much value in preserving a broad measure of legitimacy for measures, but of course risks paralysis or extreme holdout techniques (sometimes for bargaining purposes unrelated to the measure proposed.). "730

To sum up, the decision-making in the WTO is in full compliance with the principle of equality of states as it provides for equality in representation and voting powers. Majority decision-making based on equality of representation and voting power is in compliance with the principle of equality of sates as is consensus-decision making when there is equality in representation.

The following sections will not provide for a very detailed discussion of the WTO organs as equality of representation and voting power makes them compatible with the application of the principle of equality of states. There is logic to discuss in detail the various organs of an IGO (in light of the principle of equality of states) only when the IGO has plenary and non plenary organs. That would provide the opportunity to understand the differences in the rights and obligations between members in regard to representation and possibility to participate in decision-making. Such a case exists, for example, in the dualism between the Security Council and the General Assembly.

\footnotetext{
${ }^{727}$ Peter Sutherland et al. The Future of the WTO: Addressing Institutional Challenges in the New Millennium (The Sutherland Report), Geneva: WTO, 2004, pg. 63.

${ }^{728}$ Mike Moore, 'The Democratic Roots of the World Trade Organization' in Patrick F. J. Macrory, Arthur E Appleton, Michael G. Plummer, Editors, The World Trade Organization: Legal, Economic and Political Analysis, Volume I, Springer, 2005, pg. 45.

${ }^{729}$ Peter Sutherland et al. The Future of the WTO: Addressing Institutional Challenges in the New Millennium (The Sutherland Report), Geneva: WTO, 2004, pg. 17.

${ }^{730}$ John H. Jackson, Sovereignty, the WTO and Changing Fundamentals of International Law, Cambridge University Press, 2006, pg. 24.
} 
However, as all WTO members are represented in all WTO bodies (with minor exceptions) their rights and obligations in terms of representation are not impaired and therefore a more detailed coverage is not required.

In light of the application of the principle of equality of states, the most important bodies for review include the Ministerial Conference, the General Council, the Secretariat and the WTO Dispute Settlement Body.

\section{THE MINISTERIAL CONFERENCE}

Article IV: 1 of the WTO Agreement established the Ministerial Conference of the WTO. It states that:

"there shall be a Ministerial Conference composed of representatives of all the Members, which shall meet at least once every two years. The Ministerial Conference shall carry out the functions of the WTO and take actions necessary to this effect. The Ministerial Conference shall have the authority to take decisions on all matters under any of the Multilateral Trade Agreements, if so requested by a Member, in accordance with the specific requirements for decision-making in this Agreement and in the relevant Multilateral Trade Agreement". ${ }^{731}$

From the wording of Article IV:1 it is clear that the Ministerial Conference is composed of all WTO Members, which in terms of representation means that there is coherence with the principle of equality of states. Also, from the wording of the provision it is understood that the Ministerial Conference has the authority to decide on any matter requested by a Member during its meetings which are held every two years. According to the Sutherland Report, the ministers should meet annually instead of every two years. ${ }^{732}$ Except for the general power to decide on any matter, the Ministerial Conference has some specific powers, including the authority to adopt interpretations of WTO agreements, to grant waivers, to adopt amendments to the WTO agreements, decide on accession of new members, appoint the Director-General and staff regulations. ${ }^{733}$

Furthermore, the Ministerial Conference, having membership as an opportunity to all WTO members, establishes a Committee on Trade and Development, a Committee on Balance-of-Payments Restrictions and a Committee on Budget, Finance and Administration, and may establish such additional Committees with such functions as it may deem appropriate. ${ }^{734}$

\footnotetext{
${ }^{731}$ WTO Agreement, Article IV:1.

${ }^{732}$ Peter Sutherland et al. The Future of the WTO: Addressing Institutional Challenges in the New Millennium (The Sutherland Report), Geneva: WTO, 2004, pg. 69-71, 82.

${ }^{733}$ Peter Van den Bossche, The Law and Policy of the World Trade Organization: Text, Cases and Materials, Second Edition, Cambridge University Press, 2008, pg. 120. Also see WTO Agreement, Article IX, X and XII.

${ }^{734}$ See WTO Agreement, Article IV:7.
} 


\section{THE GENERAL COUNCIL}

In between the meetings of the Ministerial Conference there is a General Council which fulfills its functions. Unlike the Ministerial Conference, which is composed of minister level representatives of the governments of WTO Members, the General Council is composed of WTO member representatives at the ambassadorial level. The General Council is composed of all the Members of the WTO and conducts the functions of the Ministerial Conference in the intervals between meetings, which in practice constitutes the day-to-day work of the WTO. ${ }^{735}$ The General Council convenes as appropriate to discharge the responsibilities of the Dispute Settlement Body and the Trade Policy Review Body ${ }^{736}$ Also, open to all Members of the WTO and under the general guidance of the General Council, there is a Council for Trade in Goods, a Council for Trade in Services and a Council for Trade-Related Aspects of Intellectual Property Rights. ${ }^{737}$ The General Council is also in charge of arrangements for cooperation with other intergovernmental organizations as well as non-governmental ones. ${ }^{738}$ Unlike the Ministerial Council, which meets at least once every two years, the General Council meets in regular sessions every other month and, if needed, meets on special sessions. ${ }^{739}$ Although the Committee on Trade and Development, the Committee on Balance-ofPayments Restrictions and the Committee on Budget, Finance and Administration are, according to the WTO Agreement, established by the Ministerial Conference, they report to the General Council.

\section{THE WTO SECRETARIAT}

The WTO Agreement also foresees a Secretariat of the WTO headed by a DirectorGeneral. ${ }^{740}$ The staff is very professional and well-regarded, consisting of slightly more than 600 members of staff, and a temporary staff of $100-150$ at any other time. ${ }^{741}$ Its position is an impartial one regardless of the nationality of the staff. The Secretariat is headed by a Director-General who is appointed by the Ministerial Conference. ${ }^{742}$ Both the Secretariat and the Director-General have the positions of "international officials" with responsibilities of exclusively "international character" and do not represent the states whose nationals they are; neither will the WTO members seek to influence them

\footnotetext{
${ }^{735}$ See WTO Agreement, Article IV:2.

${ }^{736}$ See WTO Agreement, Article IV:3-4.

${ }^{737}$ See WTO Agreement, Article IV:5.

${ }^{738}$ See WTO Agreement, Article V.

${ }^{739}$ William J. Davey, 'Institutional Framework’ in Patrick F. J. Macrory, Arthur E Appleton, Michael G. Plummer, Editors, The World Trade Organization: Legal, Economic and Political Analysis, Volume I, Springer 2005, pg. 64.

${ }^{740}$ See WTO Agreement, Article VI.

${ }^{741}$ Peter Sutherland et al. The Future of the WTO: Addressing Institutional Challenges in the New Millennium (The Sutherland Report), Geneva: WTO, 2004, pg. 73.

${ }^{742}$ See WTO Agreement, Article VI (1) and (2).
} 
in "the discharge of their duties". ${ }^{743}$ The Secretariat must perform its duties in absolute neutrality and act as the "Guardian of the Treaties". ${ }^{744}$ This is, as mentioned in the previous Chapter, an organ which at least formally consists of individuals who do not represent the states whose nationals they are and are not bound by the will of any government. With regard to representation in the WTO Secretariat, it is important to discuss whether some WTO Members are significantly better represented in comparison to other WTO Members.

The appointment of the Director-General is for a four-year term with the possibility for a renewal of another four-year term. In chronological order, by nationality, the GATT/ WTO Director-Generals appointed so far were Sir Eric Wyndham-White from UK (1948-1968), Olivier Long from Switzerland (1968-1980), Arthur Dunkel from Switzerland (1980-1993), Peter Sutherland from Ireland (1993-1995), Renato Ruggiero from Italy (1995-1999), Mike Moore from New Zealand (1999-2002), Supachai Panitchpakdi from Thailand (2002-2005) and the current Director-General, Pascal Lamy from France (2005-2013). ${ }^{74}$ From these facts it is obvious that GATT had a Western European as the Director-General for almost 50 years of its existence, while the WTO so far besides two European Director-Generals has also had two Asian ones. Although there is much room for a better reflection of WTO membership in the position of the Director-General, the issue remains rather controversial and difficult to discuss from the perspective of the application of the principle of equality of states in these situations. As stated by the Sutherland Report, "regional sequencing is not a greater priority than equality". ${ }^{746}$

With regard to the Secretariat, from the 629 staff employed, an overview by nationality shows that from the existing 157 WTO Members by 2012, less than half, or 68 members, have one or more nationals employed in the Secretariat. ${ }^{747}$ It is interesting to see that the numbers range from 24 members having only one national employed, ${ }^{748}$ six members having two, ${ }^{749}$ four members having three, ${ }^{750}$ six members having four, ${ }^{751}$ nine members having five, ${ }^{752}$ fours members having six ${ }^{753}$ Colombia seven, three members having eight, ${ }^{754}$ and individual countries such as the Philippines with nine,

\footnotetext{
${ }^{743}$ See WTO Agreement, Article VI, (4).

${ }^{744}$ Peter Sutherland et al. The Future of the WTO: Addressing Institutional Challenges in the New Millennium (The Sutherland Report), Geneva: WTO, 2004, pg. 73.

${ }^{745}$ See WTO web site at: http://www.wto.org/english/thewto_e/dg_e/exdgs_e.htm, (visited March 2013).

${ }^{746}$ Peter Sutherland et al. The Future of the WTO: Addressing Institutional Challenges in the New Millennium (The Sutherland Report), Geneva: WTO, 2004, pg. 75.

747 See WTO web site at: http://www.wto.org/english/thewto_e/secre e/intro_e.htm, (visited March 2013).

${ }^{748}$ Benin, Bulgaria, Congo, Côte d'Ivoire, Cuba, Ecuador, Estonia, Ghana, Guatemala, Honduras, Hong KongChina, Hungary, Lesotho, Malawi, Nigeria, Pakistan, Saint Lucia, Senegal, South Africa, Tanzania, Thailand, Trinidad and Tobago, Uganda, Zimbabwe.

${ }^{749}$ Denmark, Mauritius, Morocco, Norway, Romania, Rwanda.

${ }^{750}$ Costa Rica, Japan, Malaysia, Turkey.

${ }^{751}$ Bolivia, Korea, New Zealand, Sri Lanka, Sweden, Venezuela.

${ }^{752}$ Austria, Belgium, Chile, China, Egypt, Finland, Greece, Peru, Poland.

${ }^{753}$ Mexico, Netherlands, Tunisia, Uruguay.

${ }^{754}$ Argentina, Australia, Brazil.
} 
Ireland eleven, India twelve, Italy thirteen, Germany sixteen, Canada twenty three, US thirty, Switzerland forty four, Spain forty six, UK seventy two and France with 181 nationals employed in the Secretariat. ${ }^{755}$

With regard to the staff of the Secretariat it is obvious that much is to be desired with regard to enhancing the representation of WTO Members in the composition of the Secretariat by nationality.

This division can be better illustrated in the following chart:

Chart 9: Overview of WTO Secretariat by nationality

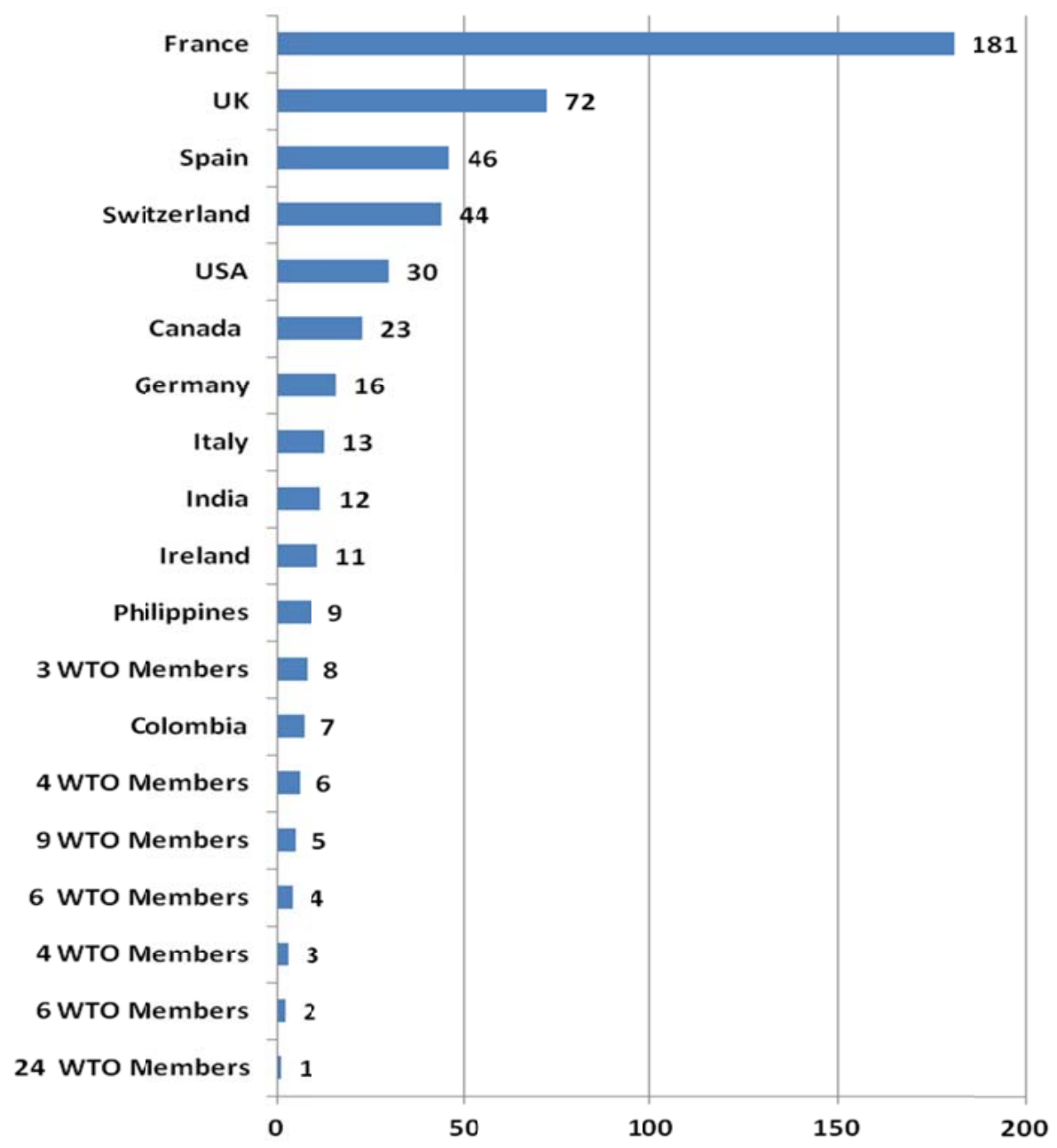

${ }^{755}$ Estimates based on the data provided on the WTO web page at: http://www.wto.org/english/thewto_e/secre_e/intro_e.htm, (visited March 2013). 
Similarly to the situation with the UN Secretariat, caution should be also exercised in stating whether in the WTO Secretariat there is (non) compliance with the principle of equality of states with regard to representation. The individuals that work in the Secretariat do not represent states. However, it can clearly be stated that the representation of WTO Members in the composition of the staff of the Secretariat can, and should be enhanced, in order to better represent the diversity of WTO Members. Needles to say, this goal should not be pursued in detriment to principles of quality, professionalism and meritocracy of the individuals that occupy these positions.

\section{THE WTO DISPUTE SETTLEMENT SYSTEM}

The WTO Dispute Settlement is administered by the Dispute Settlement Body (DSB) which represents a political institution, while the judicial-type institutions are represented by the dispute settlement panel and the Appellate Body. ${ }^{756}$ The WTO Dispute Settlement Body, the rulings of the Panels and especially the rulings of the Appellate Body also constitute a source of WTO law. The WTO administers the Understanding on Rules and Procedures Governing the Settlement of Disputes based on the provisions envisaged in Annex 2 of the WTO Agreement. ${ }^{757}$

The DSB is a political institution established by Annex 2 of the WTO Agreement. It is one of the emanations of the General Council and, as a result, is in line with the principle of equality of states as all WTO Members are represented in the DSB. It has the authority to "establish panels, adopt panel and Appellate Body reports, maintain surveillance of implementation of rulings and recommendations, and authorize suspension of concessions and other obligations under the covered agreements". ${ }^{758}$ The decision-making in the DSB is based on consensus or on reverse consensus. The novelty here, the so called "reverse consensus" in the WTO Dispute settlement system for adopting the panel reports or the final report of the Appellate Body by the Dispute Settlement Body (DSB), means that a decision is adopted automatically unless no consensus against it exists. ${ }^{759}$ Such a decision-making practice is also in line with the principle of equality of states as there is equal representation by all members in the DSB and all have equal voting powers, i.e. equal rights and obligations in the decisionmaking. No WTO Member can oppose the initiation of a dispute and the jurisdiction of the WTO Dispute Settlement Body, unlike the ICJ, is compulsory for Members. ${ }^{760}$

On the other hand, the dispute settlement panels are quasi-judicial and are established ad hoc to deal with a dispute. The panels are composed of three panelists (or at

\footnotetext{
${ }^{756}$ Peter Van den Bossche, The Law and Policy of the World Trade Organization: Text, Cases and Materials, Second Edition, Cambridge University Press, 2008, pg. 235.

${ }^{757}$ See WTO Agreement, Article III: 3.

${ }^{758}$ See DSU, Article 2.1

${ }^{759}$ Peter Sutherland et al. The Future of the WTO: Addressing Institutional Challenges in the New Millennium (The Sutherland Report), Geneva: WTO, 2004, pg. 49-50.

${ }^{760}$ Pascal Lamy, The Place of the WTO and its Law in the International Legal Order, 17 Eur. J. Int'l. L. 969 (2007), pg. 976 .
} 
times 5) if parties agree so. ${ }^{761}$ Importantly, with regard to the application of the principle of equality of states, when it comes to representation of WTO Members, is that neither the parties to the dispute nor other third parties can have a national serving as a panelist unless they agree otherwise. ${ }^{762}$ The exception to this rule is Article 8.10 of DSU stating that:

"when a dispute is between a developing country Member and a developed country Member the panel shall, if the developing country Member so requests, include at least one panelist from a developing country Member". ${ }^{763}$

Except for the panels, the WTO also has an Appellate Body which represents the most important judicial body of the WTO. Unlike the panels, it is a standing body composed of 7 Appellate Body Members. The current members of the WTO Appellate Body are: Singh Bhatia from India (2011-2015), Peter Van den Bossche from Belgium (20092013), Seung Wha Chang from Korea (2012-2016), Thomas R. Graham from United States (2011-2015), Ricardo Ramírez-Hernández from Mexico (2009-2013), David Unterhalter from South Africa (2006-2009; 2009-2013), and Yuejiao Zhang from China (2008-2012; 2012-2016). ${ }^{764}$

From the current and the previous WTO Appellate Body Members it is obvious that "only" 16 WTO members have been represented in the Appellate Body by having one or more of their nationals elected as Appellate Body Members. Furthermore, it is obvious that some major trading powers are at all times represented. This is the case with the United States having continuous representation at all times with four different Appellate Body Members elected. The EU also has continuous representation at all times by a national of an EU Member State. Japan is the third member by representation having three Appellate Body Members and being represented almost at all times, though unlike the EU and the US, Japan is not represented in the current composition of the Appellate Body Members. Next, there are the WTO Members having two of their nationals elected as Appellate Body Members, such as in the case of India (around 12 years), Egypt (around 14 years), and Philippines (around 10 years). Furthermore, South

\footnotetext{
${ }^{761}$ See DSU, Article 8.5 stating that "panels shall be composed of three panelists unless the parties to the dispute agree, within 10 days from the establishment of the panel, to a panel composed of five panelists. Members shall be informed promptly of the composition of the panel”.

${ }^{762}$ See DSU, Article 8.3.

${ }^{763}$ See DSU, Article 8.10.

764 The former WTO Appellate Body Members were: Georges Michel Abi-Saab from Egypt (20002004;2004-2008), James Bacchus from United States (1995-1999;1999-2003), Luiz Olavo Baptista from Brazil (2001-2005;2005-2009), Lilia R Bautista from the Philippines (2007-2011), Chrisopher Beeby from New Zealand (1995-1999;1999-2000), Claus-Dieter Ehlermann from Germany (1995-1997;1997-2001), Said El-Naggar from Egypt (1995-1999;1999-2000), Florentino Feliciano from the Philippines (1995-1997;19972001), Arumugamangalam Venkatachalam Ganesan from India (2000-2004;2004-2008), Jennifer Hillman from United States (2007-2011), Merit E. Janow from United States (2003-2007), Julio Lacarte-Muró from Uruguay (1995-1997;1997-2001), John Lockhart from Australia (2001-2005;2005-2006), Mitsuo Matsushita from Japan (1995-1999;1999-2000), Shotaro Oshima from Japan (2008-2012), Giorgio Sacerdoti from Italy (2001-2005;2005-2009), Yasuhei Taniguchi from Japan (2000-2003;2003-2007)See the WTO web site at: http://www.wto.org/english/tratop_e/dispu_e/ab_members_descrp_e.htm, (visited March 2013).
} 
Africa, China, Brazil, New Zealand, Uruguay and Australia have had one Appellate Body Member serving more than one term, while Mexico and Korea have one of their nationals as Appellate Body Members serving one term.

From what is stated above, unlike the General Council or the Ministerial Council where all WTO Members can be equally represented, the Appellate Body is rather limited in representation of WTO members, and is more representative of the major trading powers. For example, to date, no nationals of any LDC's have been elected as Appellate Body Members, and only few developing country members have.

However, the WTO Dispute Settlement System does provide for a special and differential treatment of LDC's and developing countries. There are a number of relevant provisions relating to special and differential treatment. There are also special rules for developing countries in Article $3.12^{765}$, Article $4.10^{766}$, Article 8.10 $0^{767}$, Article $12.11^{768}$, Article $24^{769}$, Article $27^{770}$ as well as legal assistance for developing countries by the Advisory Centre on WTO Law-ACWL. ${ }^{771}$

According to one study, although developing countries are more active in the WTO dispute settlement compared to the GATT, their main problem is their inability (lack of legal capacity and not of market power) to achieve early settlement where they have best opportunities to gain from the system. ${ }^{772}$ In similar terms, it is stated that although it is important for the poorest countries to use the system, the problem of resource constraints impedes the participation of developing countries in the WTO dispute settlement on an ongoing basis. ${ }^{773}$

\footnotetext{
${ }^{765}$ With regard to the application of the 1966 Decision if a complaint is brought by a developing country against a developed country Member.

${ }^{766}$ Article 4.10 of DSU states: “during consultations Members should give special attention to the particular problems and interests of developing country Members".

${ }^{767}$ Article 4.10 of DSU states: "when a dispute is between developing country Member and a developed country Member the panel shall, if the developing country Member so requests, include at least one panelist from a developing country Member".

${ }^{768}$ Foreseeing that when a developing country is a party to a dispute, the panel report shall "explicitly indicate the form in which account has been taken of relevant provisions on differential and more-favourable treatment for developing country Members that form part of the covered agreements which have been raised by the developing country Member in the course of the dispute settlement procedures”.

${ }^{769}$ On special procedures for Least-Developed Country Members requiring special consideration for LDC's at all stages, requiring due restraint when matters involve LDC's, due restraint in seeking compensation or authorization to suspend the application of concessions or other obligations. In addition, good offices, conciliation and mediation should be provided by the Director-General or the DSB Chairman upon request by LDC's.

${ }^{770}$ Upon request the Secretariat shall provide legal advice for developing countries through the services of a legal expert. In addition the Secretariat provides special training courses for interested Members in this regard.

${ }^{771}$ See also Peter Van den Bossche, The Law and Policy of the World Trade Organization: Text, Cases and Materials, Second Edition, Cambridge University Press, 2008, pg. 233-235.

${ }^{772}$ Marc L. Busch, Eric Reinhardt, 'Developing Countries and GATT/WTO Dispute Settlement' in George A. Berman and Petros C. Mavroidis, Editors, WTO Law and Developing Countries, Cambridge University Press, 2007, pg. 195-197.

${ }^{773}$ Niall Meagher, 'Representing Developing Countries in WTO Dispute Settlement Proceedings' in George A. Berman and Petros C. Mavroidis, Editors, WTO Law and Developing Countries, Cambridge University Press, 2007, pg. 213-214.
} 
To sum up, as stated by the Sutherland Report "by most accounts, and most measures, the operation of the dispute settlement system in the WTO has been a remarkable success" ${ }^{774}$ The WTO is better known to a casual observer for its complaints procedure rather than as the key institution in trade ${ }^{775}$ A system that replaces the "role of 'power' in international trade relations with the rule of 'law' is invariably to the advantage to the smallest and weakest countries". ${ }^{776}$

Caution should be exercised in stating whether in the WTO dispute settlement there is (non) compliance with the principle of equality of states with regard to representation as the individuals occupying these positions do not represent states. However, it can clearly be stated that representation of WTO Members in the composition of the Appellate Body can, and should be enhanced in order to better represent the diversity of WTO Members. As was stated with regard to the ICJ, it is needless to say, this goal should not be pursued in detriment to principles of quality, professionalism and meritocracy of the individuals that occupy these positions.

\section{WTO REFORM AND THE PRINCIPLE OF EQUALITY OF STATES}

The relevant discussions with regard to the application of the principle of equality of states in the WTO primarily relate to criticism to the consensus decision-making and to the equality of voting power and representation. It should be noted that any reform that would result with a shift from consensus decision-making to any other decision-making (majority or unanimity for that matter) would not be in deviation from the principle of equality of states as long as there is equality of representation and voting power. However, if reforms would result in decision-making that would include any type of a weighted voting system and/or inequality in representation they would be clearly in deviation from the principle of equality of states.

With regard to consensus decision-making, it should be noted that due to the difficulties that consensus decision-making entails by requiring that none of the WTO members objects a certain decision there is at times frustration that decisions cannot be adopted. In these lines, at one time, Pascal Lamy called WTO decision-making "medieval" ${ }^{777}$ Consensus decision-making also presents a problem for members that cannot afford to be present at meetings, as absence from a meeting does not stop decisions from

\footnotetext{
${ }^{774}$ Peter Sutherland et al. The Future of the WTO: Addressing Institutional Challenges in the New Millennium (The Sutherland Report), Geneva: WTO, 2004, pg. 50.

775 Mary E. Footer, An Institutional and Normative Analysis of the World Trade Organization, Martinus Nijhoff Publishers, 2006, pg. 1.

${ }^{776}$ Mike Moore, 'The Democratic Roots of the World Trade Organization' in Patrick F. J. Macrory, Arthur E Appleton, Michael G. Plummer, Editors, The World Trade Organization: Legal, Economic and Political Analysis, Volume I, Springer 2005, pg. 43.

777 See Statement by Pascal Lamy, WTO General Council, 26 January 2005, the WTO website at: http://www.wto.org/english/thewto_e/dg_e/stat_lamy_e.htm, (visited March 2013). This has initiated discussion whether the WTO decision-making should be reformed. See Robert Wolfe, Decision-Making and Transparency in the "Medieval” WTO: Does the Sutherland Report Have the Right Prescription, 8 J. Int'l. Econ. L. 631 (2005), pg. 631-645.
} 
being adopted by consensus. ${ }^{778}$ The Sutherland Report criticism to consensus decisionmaking seems to be relatively limited as it does not propose a replacement with another form of decision-making, but the limitation of the same by making two recommendations. The first is that WTO members should make distinctions between decisions that should be passed with (out) consensus, such as procedural issues, and the second is that a member blocking a decision for which there is general support should do so only by declaring in writing that the reasons for doing so are of vital national interest. ${ }^{779}$ Even if these recommendations for WTO reform would take place, as such, they would still be in compliance with the principle of equality of states as they do not foresee any inequality in representation or voting powers between members.

With regard to criticism related to the existing equality of representation and voting power at the WTO, the reform discussions mainly focus at the idea of introducing a type of an 'executive organ' with limited representation or/and introducing a weighted voting system.

The fact that all WTO Members have equal voting and representation powers has been criticized for not representing the stake that the individual members have in the multilateral system ${ }^{780}$ One mode to solve the difficulties of equal representation where all members are represented would be to include a non plenary body in the form of an Executive Body, composed of permanent members and non permanent members which would be a possibility for all WTO members by rotation of seats. ${ }^{781}$ Another possible reform would include the introduction of a type of weighted voting according to shares of world trade would include as permanent members: Brazil, China, EU (former EC), India, Japan, Nigeria, South Africa, US. ${ }^{782}$ If the shares of contributions to the WTO budget, the GDP and the voting rates of member are analyzed they show a significant imbalance and material inequality. For example, 24 WTO members sharing $79 \%$ of the members' total GDP and $71 \%$ of the budget represent $17 \%$ of votes; on the other hand, the 119 WTO members, sharing for the $21 \%$ of the GDP, providing for $29 \%$ of the WTO budget, represent $83 \%$ of the total votes. ${ }^{783}$ Therefore, Cottier and Takenoshita propose a formula for a weighted voting system which would include four different variables: the share of trade in goods and services together with the contribution to the WTO budget, the gross domestic product, market openness (defined as the proportion of

\footnotetext{
${ }^{778}$ Peter Sutherland et al. The Future of the WTO: Addressing Institutional Challenges in the New Millennium (The Sutherland Report), Geneva: WTO, 2004, pg. 63.

779 Ibid., pg. 64.

${ }^{780}$ Thomas Cottier, Satoko Takenoshita, 'Decision-Making and the Balance of Powers in WTO Negotiations: Towards Supplementary Weighted Voting’, in Stefan Griller, Editor, At the Crossroads: The World Trading System and the Doha Round, Springer, 2008, pg. 188.

${ }^{781}$ Members of the Executive Body would be selected by objective criteria based on GDP, share of world trade and population. See Mitsuo Matsushita, Thomas J. Schoenbaum, Petros C. Mavroidis, The World Trade Organization: Law, Practice and Policy, Oxford University Press, 2006, pg. 15.

${ }^{782}$ Mitsuo Matsushita, Thomas J. Schoenbaum, Petros C. Mavroidis, The World Trade Organization: Law, Practice and Policy, Oxford University Press, 2006, pg. 910.

${ }^{783}$ See Thomas Cottier, Satoko Takenoshita, 'Decision-Making and the Balance of Powers in WTO Negotiations: Towards Supplementary Weighted Voting', in Stefan Griller, Editor, At the Crossroads: The World Trading System and the Doha Round, Springer, 2008, pg. 188-201.
} 
imports to GDP), size of populations, and possibly basic votes. Such variables can provide for balancing in representation because the variables of GDP and trade are dominated by the industrial countries, while the variables of openness and population are dominated by the developing countries. One of the variables to include when it comes to a possibility of weighted voting is also the size of trade in goods and services and the WTO budget allocation. Accordingly, having in mind that the contribution to the WTO budget by each member is based on a three-year average share of the member in international trade, the contribution to the WTO can be used as a variable (a member providing for $0.015 \%$ of the budget should also be treated as such in the evaluation of its voting power).

This model was analyzed based on different hypotheses including: a) treating EU Member States individually and not as an entity, b) treating the EU as one entity, with the alternative to exclude intra-EU trade in the first variable (i.e. size of trade), and contrary to the existing calculation where intra-EU trade is included in assessing contributions by the individual WTO Members in three different models: without basic votes, with basic votes and with basic votes but without population. Under hypothesis one the EU would have around $30 \%$ of the vote, under hypothesis two (excluding intra-EU trade) the EU has up to $20 \%$, almost the same \% as the US. In the population variable, Asian countries have around $60 \%$ of the total world population. In both hypotheses the five WTO Members with the greatest share of voting power include: the EU, the US, Japan, China (in the meantime probably China has taken over Japan's position) and either India or Canada in the fifth place. ${ }^{784}$ However, it should be noted that Cottier and Takenoshita propose that weighted voting may "serve as a subsidiary or supplemen$\operatorname{tary}^{785}$ option for WTO negotiations when consensus diplomacy fails. ${ }^{786}$

However, it should be noted that at the same time, attempts to move away from consensus decision-making and limited representation have also been criticized. According to Moore:

"the rationale for circumventing consensus-through executive powers, weighted voting, trade sanctions- is basically that objectives which cannot be reached through persuasion should be reached through coercion...coercion is the surest

\footnotetext{
${ }^{784}$ On the specific percentages and the ramification of the different models on the two hypothesis see Thomas Cottier, Satoko Takenoshita, 'Decision-Making and the Balance of Powers in WTO Negotiations: Towards Supplementary Weighted Voting', in Stefan Griller, Editor, At the Crossroads: The World Trading System and the Doha Round, Springer, 2008, pg. 204-218.

${ }_{785}$ According to the authors the suggestion is not to replace consensus, but to supplement it by a weighted voting system to be used in cases when consensus cannot be achieved, primarily between rounds and in rounds to overcome difficulties. Furthermore, such decisions adopted by weighted voting are subject of Article X:3 of the WTO agreement, thus, allowing for members to decide whether they would like to adhere to them. See Thomas Cottier, Satoko Takenoshita, 'Decision-Making and the Balance of Powers in WTO Negotiations: Towards Supplementary Weighted Voting', in Stefan Griller, Editor, At the Crossroads: The World Trading System and the Doha Round, Springer, 2008, pg. 192-193.

${ }^{786}$ Thomas Cottier, Satoko Takenoshita, 'Decision-Making and the Balance of Powers in WTO Negotiations: Towards Supplementary Weighted Voting’, in Stefan Griller, Editor, At the Crossroads: The World Trading System and the Doha Round, Springer, 2008, pg. 186.
} 
way of poisoning the spirit of international cooperation that is so desperately needed to begin building a consensus around broader global solutions. "787

If the reform discussions suggesting the limitation of representation of WTO Members in a non-plenary body or the introduction of a weighted voting system would take place, they would be in deviation from the principle of equality of states.

To sum up, the discussions for WTO reform promoting any type of a weighted voting system and/or a non plenary body would be in deviation from the principle of equality of states. From the discussions on the proposed reform above it would be rather unlikely to state that such reforms would take place in the immediate future as many of the proposals are given as (Cottier and Takenoshita suggest) subsidiary or supplementary options when consensus fails or (as the Sutherland Report suggests) not as an abolition of the consensus decision-making but its limitation in procedural matters as well as to cases where WTO members do not have any vital interest at the decision discussed.

In fact, any reform discussions in the WTO will most likely not be in favor of the principle of equality of states. Due to the formal observance of the principle any possible reforms would very likely be more inclined towards introducing changes that would be in deviation from the principle of equality of states.

\section{DECISION-MAKING AND THE PRINICPLE OF EQUALITY OF STATES IN THE WTO}

The WTO rules on decision-making are in full compliance with the principle of equality of states. They provide for equality of representation, voting power and as a result in equality of decision-making processes, regardless of whether majority or consensus decision-making is used.

The Director-General of the WTO in this regard states the following:

"while most international economic organizations have a restricted body alongside their plenary body, the WTO is unusual in that the totality of its Members participate, as a matter of law, in all of its bodies-from the Ministerial Conference, which meets at least once every two years, to the General Council, which functions during the interim period, not to mention each of the councils and committees. All of the decisions are taken according to the principle 'one government/one vote' and by consensus. While it is true that this rule of consensus is responsible for a certain sluggishness in the negotiations, it does enable all

\footnotetext{
${ }^{787}$ Mike Moore, 'The Democratic Roots of the World Trade Organization' in Patrick F. J. Macrory, Arthur E Appleton, Michael G. Plummer, Editors, The World Trade Organization: Legal, Economic and Political Analysis, Volume I, Springer, 2005, pg. 44. He further continues: "the WTO system is the result-not the cause-of a broadening consensus about the value of open trade, painstakingly built up over fifty years”, see pg. 45.
} 
states, whatever their share in international trade, to express their views and to participate on an equal footing". 788

The one aspect of decision-making which is not reflected in the previous quote relates to the issue of representation in the WTO Secretariat and the Appellate Body. It should be noted that not all WTO Members are represented at the WTO Secretariat or the Appellate Body. This situation can be compared to the UN Secretariat and the ICJ were there was also limited representation of UN Members. The same line of reasoning as in the UN Secretariat and ICJ applies to the WTO Secretariat and the Appellate Body. Namely, due to the fact that the individuals working in these bodies do not represent, nor are bound by states whose nationals they are it is difficult to states whether there is (non) compliance with the principle of equality of states. Therefore, as stated in the previous sections, caution should also be exercised in stating whether in the WTO Secretariat or the Appellate Body there is (non) compliance with the principle of equality of states with regard to representation. Clearly, the representation of WTO Member States in the composition of the WTO Secretariat and of the Appellate Body (as in the UN Secretariat and the ICJ), can and should be enhanced, however, this goal should not be achieved in detriment to principles of quality, professionalism and meritocracy.

\section{THE BUDGET}

As any other international organization, the WTO also has its own budget. However, unlike the other major international organizations, the WTO's budget is very modest. For example, the annual budget of the WTO for 2012 was around CHF 196 mil., an amount mostly deriving from the WTO members and to an extent from miscellaneous income (rental fees, sale of WTO publications). ${ }^{789}$

According to Article VII of the WTO Agreement, the Director-General presents the annual budget estimate to the Committee on Budget, Finance and Administration. This body then makes recommendations (including scales of contribution by WTO Members) to the General Council, which adopts the annual budget by a two-thirds majority and more than half of WTO Members. ${ }^{790}$ The share of individual WTO Members is an estimate based on their share in international trade. With regard to the principle of equality of states, it is important to see the differences in contributions between the various members of the WTO. ${ }^{791}$ According to the contributions to the regular budget for 2011, the financial share of WTO Members varies from the official $0.000 \%$

\footnotetext{
${ }^{788}$ Pascal Lamy, The Place of the WTO and its Law in the International Legal Order, 17 Eur. J. Int'l. L. 969 (2007), pg. 973.

${ }^{789}$ See WTO web, at http://www.wto.org/english/thewto_e/secre_e/budget_e.htm, (visited March 2013).

${ }^{790}$ WTO Agreement, Article VII:1.

${ }^{791}$ In similar terms, also the Havana Charter stated that "Each Member shall contribute promptly to the Organization its share of the expenditure of the Organization as apportioned by the Conference” see, Article 91, ITO Charter.
} 
of the European Union, the minimum of $0.015 \%$ provided by 39 members ${ }^{792}$ up to the 10 largest financial contributors-the United States with $12.42 \%$, followed by Germany with $8.85 \%$, China with $6.87 \%$, Japan with $4.96 \%$, UK with $4.84 \%$, France with 4.48\%, Italy with 3.74\%, Netherlands with 3.23\%, Canada with $3.021 \%$ and the Republic of Korea with $2.68 \%$. These 10 largest contributors of the WTO budget together participate with $55.12 \%$ of the total WTO budget, while the remaining members participate with $44.87 \%$ of the WTO annual budget. ${ }^{793}$

This division can be better illustrated in the following chart:

\footnotetext{
792 Such as the: Antigua and Barbuda, Armenia, Barbados, Belize, Benin,

Burkina Faso, Burundi, Cape Verde, Central African Republic, Djibouti, Dominica, Fiji, Gambia, Grenada, Guinea, Guinea-Bissau, Guyana, Haiti, Kyrgyz Republic, Lesotho, Madagascar, Malawi, Maldives, Mali, Mauritania, Mongolia, Nepal, Niger, Rwanda, Saint Kits and Nevis, Saint Lucia, Saint Vincent and the Grenadines, Sierra Leone, Solomon Islands, Suriname, Swaziland, Togo, Tonga, Zimbabwe.

793 Estimates based on the data provided by the WTO web page on members' contribution at http://www.wto.org/english/thewto_e/secre_e/contrib11_e.htm, (visited March 2013).
} 


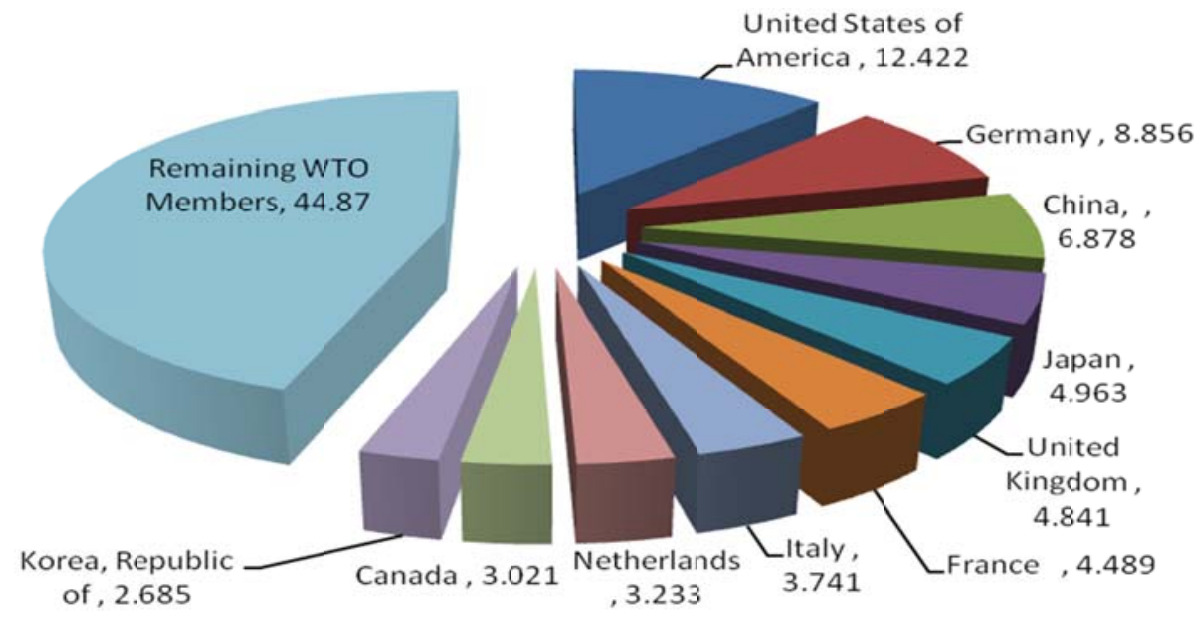

From the percentages presented above as well as from the previous years, it is obvious that there is a significant difference between WTO Members with regard to their financial contributions to the WTO budget. According to one earlier study reflecting contributions between 2001-2003, 24 WTO Members share a full 71\% of the budget, while 119 WTO Members share 29\% of the budget, thus in the ratio between vote representation and budget contribution ranges, the industrial members have 1:42 and the developing ones 1:037. ${ }^{794}$ In this regard, as in the UN, the WTO does not have a system of equal contribution by its members and with regard to equality of obligations there is a deviation from the principle of equality of states. Regarding the decision-making in adopting the budget, there is no difference in representation or voting powers between members. The majority required for adopting the budget, having in mind the equality of voting power between members is also in line with the principle of equality of states.

To sum up, while the decision-making with regard to the adoption of the WTO budget is in line with the principle of equality of states, the inequality in financing between members which results in inequality of obligations is in deviation from the principle of equality of states.

\section{SUSPENSION, EXPULSION, AND WITHDRAWAL OF MEMBERS IN THE WTO}

The WTO Agreement is silent in regard to suspension and expulsion. ${ }^{795}$

\footnotetext{
${ }^{794}$ See Thomas Cottier, Satoko Takenoshita, 'Decision-Making and the Balance of Powers in WTO Negotiations: Towards Supplementary Weighted Voting', in Stefan Griller, Editor, At the Crossroads: The World Trading System and the Doha Round, Springer, 2008, pg. 188-189.

${ }^{795}$ On the other hand, the ITO Charter had a provision on suspension of members. See ITO Charter, Article 91 which stated "A Member which is in arrears in the payment of its contributions shall have no vote in the organs of the Organization, if the amount of its arrears equals or exceeds the amount of the contributions due
} 
Therefore, as a general rule, the WTO does not foresee any possibility for a member of the WTO to be suspended or expelled. The only possible scenario for a member to be suspended or expelled is the remote possibility of WTO members outvoted by a majority concerning the amendments of the WTO Agreements, to be subjected to suspension or expulsion. ${ }^{796}$ This has never happened so far in the WTO but. And even if such a situation occurs, it would be difficult to find an argument that it is a deviation from the principle of equality of states as all members are equally represented and have equal voting powers in the relevant decision-making process.

On the other hand, with regard to withdrawal, unlike many other international organizations, the Agreement does contain a provision on withdrawal. Article XV states:

“1. Any Member may withdraw from this Agreement. Such withdrawal shall apply both to this Agreement and the Multilateral Trade Agreements and shall take effect upon the expiration of six months from the date on which written notice of withdrawal is received by the Director-General of the WTO.

2. Withdrawal from a Plurilateral Trade Agreement shall be governed by the provisions of that Agreement."797

Having in mind that it does not foresee any differences in rights and obligations of members with regard to withdrawal from the WTO, this provision is also in compliance with the principle of equality of states. Furthermore, for some authors, as discussed in Chapter III, the fact that there is a provision on withdrawal can also be interpreted as respect for the sovereign equality of states to join or to withdraw from international organizations. The fact remains that, though there is a provision on withdrawal, no WTO Member has ever withdrawn from the WTO.

\section{CONCLUSION}

From what is stated above, it is obvious that the WTO has established rules that are in compliance with the principle of equality of states, ranging from its main principle of non-discrimination, the special and preferential treatment and decision-making. The substantive law of the WTO (although beyond the scope of this book) seems to have much more far reaching implications to the application of the principle of equality of states than that of other international organizations. Moreover, having due regard for the level of economic development of its members, unlike no other international organiza-

from it in respect of the preceding two complete years. The Conference may, nevertheless, permit such a Member to vote, if it is satisfied that the failure to pay is due to circumstances beyond the control of the Member”.

${ }^{796}$ Peter Van den Bossche, The Law and Policy of the World Trade Organization: Text, Cases and Materials, Second Edition, Cambridge University Press, 2008, pg. 141-142.

${ }^{797}$ See WTO Agreement, Article XV. The wording is similar to the one of Article 102 of the ITO Charter which states that any member can withdraw from the organization upon the expiration of 6 months from the day that such notice is received by the Director General. 
tion, the WTO has a special and privileged position for the weakest of its members, the least developed countries. Although criticized as being insufficient to make a substantial change, the time and effort awarded by the WTO for the smallest and poorest countries in the trading system is remarkable by any standard. ${ }^{798}$ Whether or not the efforts by the WTO to address some of the substantive inequalities of its members are sufficient is beyond the scope of this research, and even if they were, the outcome would be very hard to predict. ${ }^{799}$ The fact that such efforts exist in that quantity, unlike in any other international organizations, should be appreciated from the perspective of the principle of equality of states. Having in mind that all these aspects are in line with the principle of equality, their strengthening and implementation should be a highly legitimate objective of the WTO.

Perhaps the greatest difficulty in the application of the principle of equality of states in the WTO can be observed in the WTO accession process. WTO accessions create inequality due to the fact that rights and obligations of WTO Members are dependent upon the terms agreed in the accession process where the position of the applicant is rather difficult due to the way that the accession process is set up. One way to address the WTO accession is to make it more of a rule-based system where a panel of experts would review the trade policies of the applicant, make recommendations on tariffs and on service sector commitments. ${ }^{800}$ This would narrow the opportunity by existing WTO Members to impose commitments above the ones they have undertaken when they joined. Although the effects of such reforms would be rather limited for future accessions, as the number of potential members is rather limited, however, it is an imperative of a rule of law and of the legitimacy of IGOs to address concerns related to the accession process.

With regard to any component of decision-making (representation, voting powers and majority or consensual decision-making), the WTO almost in absolute terms, at least formally is in line with the principle of equality of states. The fact that there is a possibility for equality in the all aspects of decision-making is also beyond what exist in other international organizations covered by this book to say the least (as seen in the UN and will be observed in the IMF). From a purely legalistic and formal perspective the principle of equality of states is applied in the WTO in decision-making. Moreover, it is not only applied in consensus based decision-making but also in majority decisionmaking. As each member has the same voting power as any other, and is subjected to the same rules when and if decisions are passed by majority, they are also in line with the principle of equality of states. The discussions on WTO reform that would introduc-

\footnotetext{
${ }^{798}$ Peter Sutherland et al. The Future of the WTO: Addressing Institutional Challenges in the New Millennium (The Sutherland Report), Geneva: WTO, 2004, pg. 17.

${ }^{799}$ For example, what would the notion "sufficient” incline?

${ }^{800}$ Roman Grynberg, Manleen Dugal and Mohammad A Razzaque, An Evaluation of the Terms of Accession to the World Trade Organization, A Comparative Assessment of Services and Goods Sector Commitments by WTO Members and Acceding Countries, Economic Paper 73, Commonwealth Secretariat, 2006, pg. 53.
} 
es any type of a weighted voting system and/or inequality in representation and voting power would be in deviation from the principle of equality of states.

To sum up, the WTO has achieved the highest standards required by the principle of equality of states. And even more, beyond the requirements of the existing international law, there are affirmative actions or positive discrimination measures to address the material inequality between members. In the current development of international law, where formal equality between states in IGOs is far from established, criticizing the one IGO that has formal equality and even moved beyond that point by addressing some aspects of material inequality is not founded. In fact, many of the criticisms of the WTO are unfounded as much is a wish list, as the expectations are neither realistic nor achievable by an international organization dealing with trade, such as the WTO. In these lines, Michael Moore, the Director-General of the WTO stated:

"they want the WTO to force open markets, preserve union jobs, strengthen labor standards, protect animal rights, preserve the environment, watch over indigenous people, save the developing world from capitalism, and a lengthening list of other goals-even when these goals are resisted by sovereign states". 801

He concludes,

"with all its imperfections, the world would be a more dangerous, less democratic place without the WTO. It is worth defending". ${ }^{802}$

The sovereign equality of states requires formal equality between states of different sizes and power, this principle is fully respected at the WTO. ${ }^{803}$

\footnotetext{
${ }^{801}$ Mike Moore, 'The Democratic Roots of the World Trade Organization' in Patrick F. J. Macrory, Arthur E Appleton, Michael G. Plummer, Editors, The World Trade Organization: Legal, Economic and Political Analysis, Volume I, Springer 2005, pg. 43-44.

${ }^{802}$ Ibid., pg. 48.

${ }^{803}$ Pascal Lamy, The Place of the WTO and its Law in the International Legal Order, 17 Eur. J. Int'l. L. 969 (2007), pg. 973.
} 


\section{CHAPTER VI \\ THE PRINCIPLE OF EQUALITY OF STATES IN THE INTERNATIONAL MONETARY FUND}

\section{INTRODUCTION}

The International Monetary Fund (the IMF/Fund) is "the world's central organization for international monetary cooperation." ${ }^{\text {"Th }}$ The IMF is working to foster economic stability and global growth by providing policy advice, financing as well as by helping developing countries to achieve macroeconomic stability and reduction of poverty. ${ }^{805}$ The Articles of Agreement define the purposes of the IMF as follows: to promote international monetary cooperation, facilitate international trade and employment, promote exchange stability, establish a multilateral system of payments, make resources of the Fund available to balance payments and tackle the degree of dequilibrium in international balances of payments. ${ }^{806}$

The IMF is considered "unique among intergovernmental organizations in its combination of regulatory, consultative, and financial functions, which derive from the

\footnotetext{
${ }^{804}$ What is the IMF? International Monetary Fund: Making the Global Economy Work for All, International Monetary Fund, 2006.

${ }^{805}$ About the IMF: Overview of the IMF, at http://www.imf.org/external/about/overview.htm, (visited March, 2013).

${ }^{806}$ Article 1 of the Articles of Agreement of the International Monetary Fund Determine the purposes of the IMF as follows:

“(i) To promote international monetary cooperation through a permanent institution which provides the machinery for consultation and collaboration on international monetary problems.

(ii) To facilitate the expansion and balanced growth of international trade, and to contribute thereby to the promotion and maintenance of high levels of employment and real income and to the development of the productive resources of all members as primary objectives of economic policy.

(iii) To promote exchange stability, to maintain orderly exchange arrangements among members, and to avoid competitive exchange depreciation.

(iv) To assist in the establishment of a multilateral system of payments in respect of current transactions between members and in the elimination of foreign exchange restrictions which hamper the growth of world trade.

(v) To give confidence to members by making the general resources of the Fund temporarily available to them under adequate safeguards, thus providing them with opportunity to correct maladjustments in their balance of payments without resorting to measures destructive of national or international prosperity.

(vi) In accordance with the above, to shorten the duration and lessen the degree of disequilibrium in the international balances of payments of members."
} 
purposes for which the institution was established”. ${ }^{807}$ It is neither a development nor a world central bank, but an international cooperation between members to maintain a stable system of currencies. ${ }^{808}$

The IMF is an independent international organization and at the same time, a Specialized Agency of the United Nations. ${ }^{809}$ Unlike the United Nations and the GATT providing for one vote for each member, the IMF has a weighted voting system based on the quota ${ }^{810}$ shares of the IMF members. ${ }^{811}$ On the other hand, similarly to the WTO and unlike the GATT, the IMF possesses juridical personality. It is vested to the Fund by Article IX:2 stating that the:

"Fund shall possess full juridical personality, and in particular the capacity: (i)

to contract; (ii) to acquire and dispose of immovable and movable property; and

(iii) to institute legal proceedings. ${ }^{, 812}$

As an International organization, the IMF strives for universality and therefore maintains an open door policy for membership. As of 2012 the IMF has reached almost full universality with 188 Members. Any country ${ }^{813}$ can become a member of the IMF upon fulfillment of certain conditions set in the Articles of Agreement of the Fund, and any member of the IMF may leave at any time. ${ }^{814}$

This chapter discusses the application of the principle of equality of states in the: (1) Articles of Agreement of the IMF; (2) acquisition of membership; (3) decisionmaking; (4) financing of the IMF; and (5) suspension, expulsion and withdrawal from membership of the IMF.

\footnotetext{
${ }^{807}$ See Financial Organization and Operations of the IMF, Treasurer's Department, International Monetary Fund 2001, IMF Pamphlet Series No. 45, Sixth Edition, Treasurer's Department, International Monetary Fund, 2001,pg. 2.

${ }^{808}$ David D. Driscoll, What is the International Monetary Fund?, International Monetary Fund, 1998, pg. 1.

${ }^{809}$ See the Agreement Between the United Nations and the International Monetary Fund, November 15, 1947, Article 1, (2). Also see Eva Riesenhuber, The International Monetary Fund Under Constraint: Legitimacy of its Crisis Management, Kluwer Law International, 2001, pg. 3.

${ }^{810}$ On quota shares and weighted voting see below, pg. 267-283.

${ }^{811}$ Andreas F. Lowenfeld, The International Monetary System: A Look Back Over Seven Decades, 13 J. Int'l. Econ. L. 575 (2010), pg. 577.

${ }^{812}$ Articles of Agreement of the International Monetary Fund, Article IX Sec. 2

${ }^{813}$ Note that the IMF refers to its members (and even non members) as "countries", see Articles II, IV, VIII, XI, XXXI of the Articles of Agreement; or as a "country" (see Article XXXI, Schedule M of the Articles of Agreement). There is no mention of the term "state” in the IMF Articles of Agreement. Therefore, this chapter will refer to IMF members as country/countries as specified by the Articles of Agreement.

${ }^{814}$ Eva Riesenhuber, The International Monetary Fund Under Constraint: Legitimacy of its Crisis Management, Kluwer Law International, 2001, pg. 3.
} 


\section{THE IMF ARTICLES OF AGREEMENT AND THE PRINCIPLE OF EQUALITY OF STATES}

The Articles of Agreement of the IMF (the Articles of Agreement) represent the founding treaty of the IMF. ${ }^{815}$ The Articles of Agreement were adopted at the Bretton Woods Conference in July of 1944 and entered into force upon the signature of 29 countries which at the time represented $80 \%$ of the original quotas. ${ }^{816}$ Unlike the UN Charter or the WTO Agreement, the IMF Articles of Agreement entered into force only when the number of signatories at the same time represented a percentage of the required quota. Such a requirement represents a deviation from the principle of equality of states as it weighs between the signatures of equal states. The quota necessary for the adoption of the Articles of Agreement was set out at \$ 6, 772.5 millions and was achieved by the signatures of Belgium, Bolivia, Canada, China, Colombia, Czechoslovakia, Egypt, Ethiopia, France, Greece, Honduras, Iceland, India, Iraq, Luxembourg, Netherlands, Norway, Philippines, South Africa, UK, US and Yugoslavia. ${ }^{817}$

The Articles of Agreement contain 31 Articles that regulate inter alia issues such as: purposes of the Fund, membership, subscriptions and quotas, obligations regarding exchange arrangements, status of the fund, relations with other institutions and other non member states, organization and management, termination of participation, withdrawal from membership. Thirteen Schedules (A,B,C,D,E,F,G,H,I,J,K,L,M) are also part of the Articles of Agreement and deal with issues such as: quotas, par values, election of the Executive Directors, termination of participation, suspension of voting rights. ${ }^{818}$ Like the WTO Agreement, and unlike the UN Charter, no provision of the Articles of Agreement (including the Schedules) has any direct references to the principle of equality of states. However, despite the fact that there are no direct references in the Articles of Agreement, the principle of equality of states is considered to be a part of the IMF. One argument in favor of this proposition is based on the fact that the IMF is a

\footnotetext{
${ }^{815}$ Adopted at the United Nations Monetary and Financial Conference, Bretton Woods, New Hampshire, July 22, 1944. Entered into force December 27, 1945. Amended effective July 28, 1969, by the modifications approved by the Board of Governors in Resolution No. 23-5, adopted May 31, 1968; amended effective April 1, 1978, by the modifications approved by the Board of Governors in Resolution No. 31-4, adopted April 30, 1976; amended effective November 11, 1992, by the modifications approved by the Board of Governors in Resolution No. 45-3, adopted June 28, 1990; amended effective August 10, 2009, by the modifications approved by the Board of Governors in Resolution No. 52-4, adopted September 23, 1997; amended effective February 18, 2011, by the modifications approved by the Board of Governors in Resolution No. 63-3, adopted May 5, 2008; and amended effective March 3, 2011, by the modifications approved by the Board of Governors in Resolution No. 63-2, adopted April 28, 2008. Available online on the IMF web site at: http://www.imf.org/external/pubs/ft/aa/index.htm, (visited March 2013).

${ }^{816}$ See IMF Chronology at, http://www.imf.org/external/np/exr/chron/chron.asp, (visited March 2013).

${ }^{817}$ Joseph Gold, Membership and Nonmembership in the International Monetary Fund: a study in international law and organization, International Monetary Fund, 1974, pg. 17.

${ }^{818}$ See Schedules of the Articles of Agreement of the International Monetary Fund.
} 
Specialized Agency of the United Nations. ${ }^{819}$ Therefore, according to Efraim, the principle of equality of states applies to the IMF. She states:

"in virtue of its status as a UN Specialized Agency, the IMF is subject to the terms of the UN Charter, including the ones related to the principle of Sovereign Equality". ${ }^{820}$

An international organization becomes a Specialized Agency upon reaching an agreement with the United Nations providing for such status. ${ }^{821}$ The United Nations signed an Agreement with the International Monetary Fund on November 15, 1947. ${ }^{82}$ This Agreement explicitly states that the Fund is a Specialized Agency. ${ }^{823}$ However, it is rather unclear how the principle of equality of states applies to the IMF specifically due to the fact that the Fund is a Specialized Agency. The Agreement between the UN and the IMF has no references to the principle of equality of states or to the principles of the Charter. It is clear that the IMF as a Specialized Agency is institutionally better linked to the UN in comparison to the IGOs that have not acquitted such status. For example, the Agreement grants the IMF the right to request advisory opinions of the International Court of Justice, share statistical data and have closer administrative relations. ${ }^{824}$ However, it would be an overstatement to say that the principle of equality of states applies to the IMF because it is a Specialized Agency. By analogy, the principle applies also to all other IGOs that have no references to the principle of equality of states and are UN Specialized Agencies, but not to the IGOs that are not Specialized Agencies of the UN and have no references to the principle of equality of states (such as the WTO). In fact the IMF and World Bank are the main international organizations that use weighted voting and at the same time are UN specialized agencies. ${ }^{825}$ The principle of equality of states applies to the IMF for a simple reason: the IMF is an international organization.

${ }^{819}$ See Athena Debbie Efraim, Sovereign (In)equality in International Organizations, Martinus Nijhoff, pg. 193-194.

${ }^{820}$ Ibid.

${ }^{821}$ According to Article 57 of the UN Charter, "the various specialized agencies, established by intergovernmental agreement and having wide international responsibilities, as defined in their basic instruments, in economic, social, cultural, educational, health, and related fields, shall be brought into relationship with the United Nations in accordance with the provisions of Article 63.2. Such agencies thus brought into relationship with the United Nations are hereinafter referred to as specialized agencies”. Further on, Article 63 of the Charter states that "1.The Economic and Social Council may enter into agreements with any of the agencies referred to in Article 57, defining the terms on which the agency concerned shall be brought into relationship with the United Nations. Such agreements shall be subject to approval by the General Assembly. 2. It may coordinate the activities of the specialized agencies through consultation with and recommendations to such agencies and through recommendations to the General Assembly and to the Members of the United Nations.”. On specialized and their relations to the United Nations see Philippe Sands and Pierre Klein, Bowett's Law of International Institutions, Sixth Edition, Sweet \& Maxwell, 2009, pg. 75-81.

${ }^{822}$ See the Agreement Between the United Nations and the International Monetary Fund, November 15, 1947.

${ }^{823}$ Article II, 1 of the Agreement Between the United Nations and the International Monetary Fund, November 15, 1947.

${ }^{824}$ See Article VIII, IX, X of the Agreement Between the United Nations and the International Monetary Fund, November 15, 1947

${ }^{825}$ Nigel D. White, 'Decision-making' in Jan Klabbers and Åsa Wallendahl, Editors, Research Handbook on the Law of International Organizations, Edward Elgar Publishing Limited, 2011, pg. 234. 
International organizations (including the IMF) are bound by international law and the law of international organizations including the principle of equality of states. The fact that the Articles of Agreement do not provide any direct reference to the principle of equality of states does not mean that they do not affect the application of the principle in the IMF. For example, there is no veto provision in the IMF. However, as it will be seen, the majorities required for major decisions provide de facto veto powers for the United States and the EU (if EU Members vote in a group). ${ }^{826}$

Another example is the fact that the International Monetary Fund is based in Washington D.C., United States of America. According to Article XIII of the Articles of Agreement "the principal office of the Fund shall be located in the territory of the member having the largest quota" ${ }^{827}$ Although it is obvious that the "member having the largest quota" are the United States, it is also obvious that Article XIII does not concretely specify the member with the largest share. This is done by the By-Laws ${ }^{828}$ of the IMF which clearly state that the "principal office of the Fund shall be located within the metropolitan area of Washington, D.C., United States of America”. ${ }^{829}$

The application of the principle of equality of states in the IMF is determined also by the provisions dealing with issues related to IMF membership such as: acquisition of membership, decision-making, financing, as well as withdrawal, suspension and expulsion (compulsory withdrawal). All these aspects of IMF membership and the application of the principle of equality of states will be reviewed in more detail in the sections to follow.

To sum up, contrary to the principle of equality of states, the IMF Articles of Agreement entered into force only when the number of signatories at the same time represented a percentage of the required quota. Such a requirement is a deviation from the principle of equality of states as it weighs between the signatures of equal states. The Articles of Agreement do not have any direct references to the principle of equality of states. However, the principle of equality of states applies in the IMF due to the fact that the Fund is an international organization and a Specialized Agency of the United Nations. Although, the Articles of Agreement do not have direct references to the principle of equality of states, they affect the application of the principle of equality of states throughout the provisions dealing with IMF membership.

\footnotetext{
${ }^{826}$ Andreas F. Lowenfeld, The International Monetary System: A Look Back Over Seven Decades, 13 J. Int'l. Econ. L. 575 (2010), pg. 577.

${ }^{827}$ Articles of Agreement of the IMF, Article XIII, Section 1.

${ }^{828}$ Except for the Articles of Agreement of the IMF as the primary source of the organization, there are also By-Laws of the International Monetary Fund and the Rules and Regulations of the Fund that deal with applications for membership. The By-Laws are adopted under the authority and are complementary to the Articles of Agreement. See the text of the By-Law at the IMF web page at: http://www.imf.org/external/pubs/$\mathrm{ft} / \mathrm{bl} / \mathrm{blcon} . \mathrm{htm}$, (visited March 2013).

${ }^{829}$ See IMF By-Laws, Section 1, adopted March 16, 1946, amended June 13, 1978. The decision to locate the offices in Washington D.C. was made at the inaugural meeting of the Board of Governors held in Savannah, Georgia from March 8-18, 1946, where the Board of Governors also adopted the By-Laws of the IMF; see UN Yearbook 1946/47, Part II, Chapter VI, The International Monetary Fund, pg. 768.
} 


\section{ACQUISITION OF MEMBERSHIP IN THE IMF}

From the original 35 members having signed the IMF Articles of Agreement by December 31, 1945, the number of members doubled to 70 by 1959, quadrupled to 140 by 1978 and reached 188 members by $2012 .{ }^{830}$ The following chart presents the increase of membership and the interest of almost the absolute majority of the states to be part of this important financial institution. According to this data, the IMF membership has increased by $500 \%$ in almost seven decades. This increase of IMF membership can be better illustrated in the following chart:

Chart 11: Increase of IMF membership through the years

\footnotetext{
${ }^{830}$ The 188 Members of the IMF are: Belgium, Bolivia, Canada, China, Colombia, Czechoslovakia, Egypt, Ethiopia, France, Greece, Honduras, Iceland, India, Iraq, Luxembourg, Netherlands, Norway, Philippines, South Africa, United Kingdom, United States, Yugoslavia , Dominican Republic, Ecuador, Guatemala, Paraguay, Iran Islamic Republic of (Iran), Chile, Mexico, Peru, Costa Rica, Poland, Brazil, Uruguay, Cuba, El Salvador, Nicaragua, Panama, Denmark, Venezuela, Bolivia, Turkey, Italy , Syria, Lebanon, Australia, Finland, Austria, Thailand (Siam), Pakistan , Sri Lanka (Ceylon), Sweden, Myanmar (Burma), Japan, Germany, Jordan, Haiti , Indonesia, Israel, Afghanistan, Islamic Rep. of (Afghanistan) ,Korea ,Argentina, Vietnam, Ireland, Saudi Arabia, Sudan, Ghana, Malaysia, Tunisia, Morocco, Spain, Libya, Portugal, Nigeria, Lao People's Democratic Republic (Laos), New Zealand, Nepal, Cyprus, Liberia, Togo, Senegal, Somalia, Sierra Leone, Tanzania, Kuwait, Jamaica, Côte d'Ivoire (Ivory Coast), Niger, Burkina Faso, Cameroon, Central African Republic, Chad, Congo, Benin, Gabon, Mauritania, Trinidad and Tobago, Madagascar, Algeria, Mali, Uganda, Burundi, Congo, Democratic Republic of the (Zaire), Guinea, Rwanda, Malawi, Zambia, Singapore, Guyana, Indonesia, Gambia, Botswana, Lesotho, Malta, Mauritius, Swaziland, Yemen, Equatorial Guinea, Cambodia, Barbados, Fiji, Oman, Samoa (Western Samoa),Bangladesh, Bahrain, Qatar, United Arab Emirates, Romania, Bahamas, Grenada, Papua New Guinea, Comoros, Guinea-Bissau, Seychelles, São Tomé and Príncipe, Maldives, Suriname, Solomon Islands, Cape Verde, Dominica, Djibouti, St. Lucia, St. Vincent and the Grenadines, Zimbabwe, Bhutan, Vanuatu, Antigua and Barbuda, Belize, Hungary, St. Kitts and Nevis, Mozambique, Tonga, Kiribati, Poland, Angola, Yemen, Czechoslovakia, Bulgaria, Namibia, Mongolia, Albania, Lithuania, Georgia, Kyrgyz Republic (Kyrgyzstan), Latvia, Marshall Islands, Estonia, Armenia, Switzerland, Russian Federation, Belarus, Kazakhstan, Moldova, Ukraine, Azerbaijan, Uzbekistan, Turkmenistan, San Marino, Bosnia and Herzegovina, Croatia, Macedonia- former Yugoslav Republic, Slovenia, Serbia, Czech Republic, Slovak Republic, Tajikistan, Micronesia, Eritrea, Brunei, Palau, Timor-Leste (East Timor), Montenegro, Kosovo, Tuvalu, and South Sudan. For specific dates when individual members joined the IMF see IMF web site at: http://www.imf.org/external/np/sec/memdir/memdate.htm, (visited March, 2013)
} 


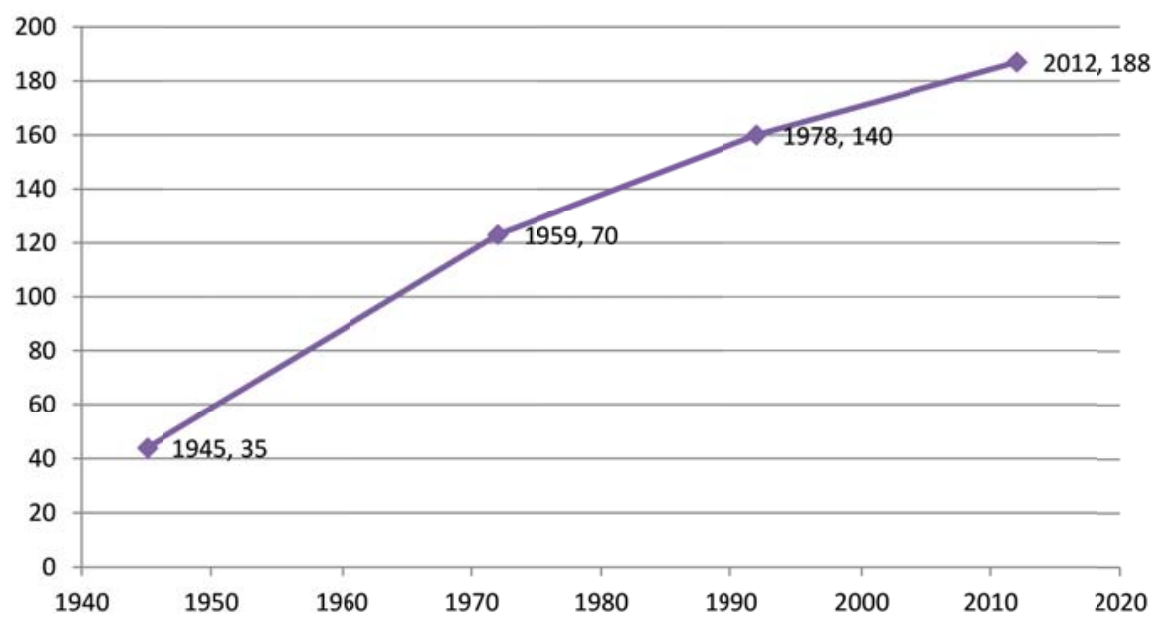

Article II of the Articles of Agreement titled “membership” provides for a distinction between "original members" and "other members" of the Fund. As a result, a country may acquire membership of the IMF either as an original member or through the admission process. Original membership was basically acquired by participating in the negotiations for the establishment of the IMF. After the establishment of the IMF, membership is only possible through admission to the IMF. Around 1/5 of current members of the IMF are original members, while around $4 / 5$ have joined as other members.

Unlike the acquisition of membership of the UN and of the WTO, the acquisition of membership of the IMF is a condition (not a right) to join the International Bank for Reconstruction and Development (IBRD), and membership in the IBRD is a condition to join the International Development Association (IDA) and the International Finance Corporation (IFC). ${ }^{831}$

This section discusses the application of the principle of equality of states: first, in the negotiations for the establishment of the IMF, second, in the acquisition of original membership of the Fund and third, in the acquisition of membership as "other members”.

\section{THE PRINCIPLE OF EQUALITY OF STATES IN THE NEGOTIATIONS FOR THE ESTABLISHMENT OF THE IMF}

The participation of states in the negotiations for the establishment of the IMF was important for at least two reasons. First, the countries participating in the negotiations had the opportunity to be part of the decision-making on the establishment of the IMF and influence the outcome. Second, the countries participating in the negotiations

${ }^{831}$ C. F. Amerasinghe, Principles of Institutional Law of International Organizations, Second Edition, Cambridge University Press, 2005, pg. 106. 
acquired the right to become original members of the IMF and no admission decision was required for acquiring membership.

The negotiations for the establishment of the International Monetary Fund in general terms can be divided in two parts: first, the pre-Bretton Woods negotiations covering the preparations for the Bretton Woods Conference and second, the Bretton Woods Conference. ${ }^{832}$

\section{A. PRE BRETTON WOODS NEGOTIATIONS}

The pre-Bretton Woods negotiations cover all the negotiations that started from the beginning of WW II up to beginning of the Bretton Woods Conference in June 1944. The initiative for the establishment of the IMF was largely undertaken by the leadership of the United States and the United Kingdom. The US positions were embodied in the "White Plan", developed by Harry Dexter White. The "White Plan" called for a "United Nations Stabilization Fund and a Bank for Reconstruction and Development of the United and Associated Nations". ${ }^{833}$ Britain's positions were embodied in the "Keynes Plan", developed by Maynard Keynes in the United Kingdom which called for an International Currency Union or a Clearing Union. ${ }^{834}$ While the Keynes Plan was dating back to 1941, the White Plan was being (re) drafted as of 1940 and they were both made public in $1942 .{ }^{835}$ In 1942 the two proposals were exchanged not only between the United States and the United Kingdom but also with other governments associated with them during the war. In order to resolve some of the more contentious issues, Keynes and White met nine times with their respective delegations in Washington during September and October of 1943, and produced the "Joint Statement by Experts on the Establishment of an International Monetary Fund" ${ }^{836}$ Besides the US and the UK, participation in the negotiations at this phase was rather limited. Only Canada and France ${ }^{837}$ sent their views to the proposed plan while other governments were even less present. ${ }^{838}$ Keynes was openly not in favor of having small and developing countries in the planning as he feared that the "delegates with little to contribute would get in the

\footnotetext{
${ }^{832}$ Note that only participation in the Bretton Woods Conference was relevant for acquisition of original membership.

${ }^{833}$ See the "Preliminary Draft Proposal for a United Nations Stabilization Fund and a Bank for Reconstruction and Development of the United and Associated Nations" of April, 1942; and the "Preliminary Draft Outline of a Proposal for an International Stabilization Fund of the United and Associated Nations”, Revised July 10, 1943.

${ }^{834}$ See the "Proposals for an International Currency (or Clearing) Union of February 11, 1942; and the "Proposals for an International Clearing Union" of April 1943. According to Keynes, the head office of the organization should be in London while the Board of Managers would meet alternatively in London and Washington, See Point 56 of the Fourth Draft of Lord Keynes’ plan for a Clearing Union of February 11, 1942 ,

${ }^{835}$ Margaret Garritsen de Vries, IMF in a Changing World: 1945-85, International Monetary Fund, 1986, pg. 7.

${ }^{836}$ Ibid., 7-8.

${ }^{837}$ The French Plan called for the organization to be named as the "International Clearing Office".

${ }^{838}$ See The International Monetary Fund 1945-1965: Twenty Years of International Monetary Cooperation, Volume III: Documents, International Monetary Fund, 1969, pg. 97.
} 
way of the leading men". ${ }^{839}$ Therefore, he argued that the United States and the United Kingdom should:

"settle the charter and the main details of the new body without being subjected to the delays and confused counsels of an international conference. It would also mean that considerable progress could be made irrespective of the nature of the European political settlement and before the conditions of adherence of the European members could be finally determined. Moreover, membership would be thus established as a privilege only open to those who conformed to certain general principles and standards of international economic conduct. The management and the effective voting power might inhere permanently in the founderStates. ${ }^{840}$

The proposed plan for a Currency Union by Keynes stated that the Union should be founded by the United States and the United Kingdom, and that they would be considered the "founder-States". ${ }^{841}$ Russia may become the third founder although a special consideration should be made if she can be a party to an institution so "capitalist looking” ${ }^{842}$ It was considered at the time that to exclude a country such as Russia would be an error because "to deny her the privileges of joining in the comparative effort to improve world economic relations would be to repeat the tragic errors of the last generations". ${ }^{843}$ Others would then be allowed to join. The French Plan also suggested that France should be one of "principal nations" and that the rest should join after. It stated: "the principal nations, as in the case of the tripartite agreement of 1936, might conclude a monetary accord among themselves, to which the other United Nations might be invited to adhere, under certain conditions. ${ }^{844}$

Eventually, other states were able to participate in a more limited capacity after much of the work was prepared by White and Keynes. A preliminary drafting conference to prepare for the Bretton Woods was held in Atlantic City with the participation of the following 17 countries: the United States, Australia, Belgium, Brazil, Canada, Chile, China, Cuba, Czechoslovakia, France, Greece, India, Mexico, the Netherlands, Norway, the Soviet Union and the UK. ${ }^{845}$ The Atlantic City conference was used to complete the preparations for the Bretton Woods Conference.

\footnotetext{
${ }^{839}$ James M. Boughton, Silent Revolution: The International Monetary Fund, 1979-1989, The International Monetary Fund, 2001, pg. 963.

${ }^{840}$ See Point 55 of the Fourth Draft of Lord Keynes’ plan for a Clearing Union of February 11, 1942.

${ }^{841}$ See Point 3 of the Fourth Draft of Lord Keynes' plan for a Clearing Union of February 11, 1942.

${ }^{842}$ Based on these thoughts it was foreseen that the founder states would permanently inhere the management and the effective voting power. See Joseph Gold, Membership and Nonmembership in the International Monetary Fund: a study in international law and organization, International Monetary Fund, 1974, pg. 7-8.

${ }^{843}$ Joseph Gold, Membership and Nonmembership in the International Monetary Fund: a study in international law and organization, International Monetary Fund, 1974, pg. 129.

${ }^{844}$ See Point 4 of the "French Plan” named "Suggestions Regarding International Monetary Relations of May, 1943.

${ }^{845}$ Margaret Garritsen de Vries, IMF in a Changing World: 1945-85, International Monetary Fund, 1986, pg. 9.
} 


\section{B. THE BRETTON WOODS CONFERENCE}

The Breton Woods Conference started in July 1944, chronologically, nine months before the UN Charter and ten months before the war ended in Europe. ${ }^{846}$ Unlike the rather limited participation of states in the preparatory work for the establishment of the IMF, representatives of 45 nations assembled at a grand hotel in Bretton Woods, New Hampshire, to create the organization and draft the rules for the post-war international financial system. ${ }^{847}$ Participation at the conference was possible only for the governments having received an invitation by the United States. The US Secretary of State sent an invitation to the representatives of the following countries: Australia, Belgium, Bolivia, Brazil, Canada, Chile, China, Colombia, Costa Rica, Cuba, Czechoslovakia, Dominican Republic, Ecuador, Egypt, El Salvador, Ethiopia, French Committee of National Liberation, Greece, Guatemala, Haiti, Honduras, Iceland, India, Iran, Iraq, Liberia, Luxembourg, Mexico, Netherlands, New Zealand, Nicaragua, Norway, Panama, Paraguay, Peru, Philippine, Commonwealth, Poland, Union of South Africa, Union of Soviet Socialist Republics, United Kingdom, Uruguay, Venezuela, and Yugoslavia. ${ }^{848}$ It is clear that not all of the participants at the Conference were states at the time. As mentioned in the previous sections this was not the case with India and the Philippines at that time. Regardless of this fact, the participants were granted full membership at the conference and in line with the principle of equality of states, equal voting powers as each delegation had one vote. ${ }^{849}$ Although all Conference participants were considered equal, the United States pretty much determined the structure as well as the location and the mandate of the IMF (and of the WB). ${ }^{850}$ The main Commission in charge of the establishment of the IMF, the Commission I, was headed by White, while Keynes headed Commission II on the World Bank. This was a logical result of the fact that it

\footnotetext{
${ }^{846}$ Andreas F. Lowenfeld, International Economic Law, Second Edition, Oxford University Press, 2008, pg. 600.

${ }^{847}$ See details about IMF History at: http://www.imf.org/external/about/histcoop.htm; also see Andreas F. Lowenfeld, The International Monetary System: A Look Back Over Seven Decades, 13 J. Int'l. Econ. L. 575 (2010), pg. 575-595.

${ }^{848}$ See Proceedings and Documents of the United Nations Monetary and Financial Conference, Bretton Woods, New Hampshire, July 1-22, 1944, Vol. I, Department of State, Publication 2866, International Organization and Conference Series I, 3, pg. 4.

${ }_{849}$ See Proceedings and Documents of the United Nations Monetary and Financial Conference, Bretton Woods, New Hampshire, July 1-22, 1944, Vol. II, Department of State, Publication 2866, International Organization and Conference Series I, 3, pg. 1134. According to the practice of international conferences, the host state designated the Temporary President of the conference (Secretary Morgenthau) and the Secretariat, see pg. 1135.

${ }^{850}$ Ngaire Woods, 'The United States and the International Financial Institutions: Power and Influence Within the World Bank and the IMF' in Rosemary Foot, S. Neil MacFarlane and Michael Mastanduno, Editors, US Hegemony and International Organizations: The United States and Multilateral Institutions, Oxford University Press, 2003, pg. 92. Also see John W. Pehle, The Bretton Woods Institutions, 55 Yale L. J. 1127 (1946), pg. 1128, attributing the merits of drafting the planning of the program for the development of Bretton Woods to the United States Treasury.
} 
was the White Plan the one that was used as the basis for the development of the Fund. ${ }^{851}$

The most important decisions on the application of the principle of equality of states were adopted up at the Bretton Woods Conference. These decisions include inter alia the adoption of a weighted voting system and management structures foreseeing limited representation of members. The decisions on assigning the quota for members, unequal voting powers, and limited representation were all reflected at the Articles of Agreement drafted at the Bretton Woods Conference. It was obvious that the drafters at the Bretton Woods Conference entertained only:

"few thoughts about abstract principles of sovereign equality; they were more concerned with creating institutions in which the Allied powers could serve as monitors of the international economy". 852

By the end of the Bretton Woods Conference, the Articles of Agreement were adopted on July 22, 1944 and entered into force December 27, 1945, the same days as the ones of the World Bank. As part of the adopted Articles of Agreement, Schedule A introduced a quota share for the participating countries confirming the weighted voting in the organization based on the assigned quotas for IMF Members. The original Bretton Woods formula used for the calculation of quotas of the following 45 countries at Bretton Woods included such economic variables as the national income, the reserves of the country, external trade, and export fluctuations. ${ }^{853}$ The British (Keynes) plan proposed the trade volume of the pre-war years as a basis hoping to establish a primacy in the voting power, however, the plan proposed by the US (White) having the largest subscriber as a basis was adopted. ${ }^{854}$ It is interesting that Raymond Mikesell, the author of the original formula at Bretton Woods was charged by White to devise a formula that:

"would yield a quota of approximately 3 billion dollars for the United States, provide half that amount for Great Britain, and grant third and fourth place to the Soviet Union and China, respectively-parameters that had been set by the president and the secretary of state." ${ }^{855}$

\footnotetext{
${ }^{851}$ See Margaret Garritsen de Vries, IMF in a Changing World: 1945-85, International Monetary Fund, 1986, pg. 10.

${ }^{852}$ Stephen Zamora, Voting in International Economic Organizations, 74 Am. J. Int'l. L. 566 (1980), pg. 576.

${ }^{853}$ Leo Van Houtven, Governance of the IMF: Decision-making, Institutional Oversight, Transparency, and Accountability, Pamphlet Series No. 53, International Monetary Fund, 2002, pg. 5.

${ }^{854}$ Elizabeth McIntyre, Weighted Voting in International Organizations, 8 Int'l. Org. L. Rev. 484 (1954), pg. 487-488.

${ }^{855}$ Randall W. Stone, Controlling Institutions: International Organizations and the Global Economy, Cambridge University Press, 2011, pg. 53.
} 
The following table provides specific information on the quota shares based on Schedule A of the Articles of Agreement adopted at the Bretton Woods conference reflecting the formula devised by Mikesell:

Table 5: Share of quota according to the Schedule A of the Articles of Agreement

\begin{tabular}{|c|c|c|c|}
\hline \multicolumn{4}{|c|}{$\begin{array}{c}\text { ARTICLE OF AGREEMENT OF THE IMF } \\
\text { Schedule } \mathrm{A}^{856}\end{array}$} \\
\hline IMF MEMBER & QUOTA & IMF MEMBER & QUOTA \\
\hline Australia & 200 & India & 400 \\
\hline Belgium & 225 & Iran & 25 \\
\hline Bolivia & 10 & Iraq & 8 \\
\hline Brazil & 150 & Liberia & 5 \\
\hline Canada & 300 & Luxembourg & 10 \\
\hline Chile & 50 & Mexico & 90 \\
\hline China & 550 & Netherlands & 275 \\
\hline Colombia & 50 & New Zealand & 50 \\
\hline Costa Rica & 5 & Nicaragua & 2 \\
\hline Cuba & 50 & Norway & 50 \\
\hline Czechoslovakia & 125 & Panama & 5 \\
\hline Denmark. & $*$ & Paraguay & 2 \\
\hline Dominican Rep. & 5 & Peru & 25 \\
\hline Ecuador & 5 & Philippines & 15 \\
\hline Egypt & 45 & Poland & 125 \\
\hline El Salvador & 2.5 & South Africa & 100 \\
\hline Ethiopia & 6 & USSR & 1200 \\
\hline France. & 450 & UK & 1300 \\
\hline Greece & 40 & United States & 2750 \\
\hline Guatemala & 5 & Uruguay & 15 \\
\hline Haiti & 5 & Venezuela & 15 \\
\hline Honduras. & 2.5 & Yugoslavia & 60 \\
\hline Iceland. & 1 & & \\
\hline
\end{tabular}

The Bretton Woods Conference is considered to represent a landmark in the history of world economy that can only be explained as "coincidence of the hour and the men". ${ }^{857}$ While this may be the case for the world economy, it is certainly not the case for the principle of equality of states. For the principle of equality of states in international

${ }^{856}$ See Schedule A, Articles of Agreement of the International Monetary Fund. Schedule A in the footnote also states that "the quota of Denmark shall be determined by the Fund after the Danish Government has declared its readiness to sign this Agreement but before signature takes place”. All the countries of the Schedule A except for the USSR became members of the IMF.

${ }^{857}$ Margaret Garritsen de Vries, IMF in a Changing World: 1945-85, International Monetary Fund, 1986, pg. 5. 
organizations the Bretton Woods conference may be considered as the landmark conference that introduced a system of weighted voting on a major scale which clearly represents a deviation from the principle of equality of states.

\section{ORIGINAL MEMBERS OF THE IMF AND THE PRINCIPLE OF EQUALITY OF STATES}

Original members are the countries of the IMF that were represented at the United Nations Monetary and Financial Conference which accepted membership before December 31, 1945. ${ }^{858}$ Article II, Section 1 of the Articles of Agreement, states that the original members of the Fund shall be the "countries represented at the United Nations Monetary and Financial Conference whose governments accept membership before December 31, 1945". ${ }^{859}$ Note that the "United Nations Monetary and Financial Conference" was the formal name of the Bretton Woods Conference.

If conditions for original membership are analyzed, it is obvious that there are three basic conditions to be met in order for a country to become an original member of the IMF. First, is that the member is a country, second, that the country has participated at the UN Monetary and Financial Conference and third, that it accepts membership before December 31, 1945.

With regard to the first condition, that the original member is a country, no clear criteria existed. It is interesting that the word used is not a "state" but the "country". According to Gold, perhaps the reason that the drafters decided to use the word "country" instead of "state" had to do with the inability to agree on the definition of the "state" as well as and due to the characteristics of some of the participants in the Bretton Woods conference such as the British Dominions (Australia, Canada, New Zealand, South Africa), India and the Philippines. ${ }^{860}$ As stated, although India and the Philippines were not states at the time, they had the right to participate in the Conference. Furthermore, they were given the opportunity to become original members of the IMF. This clearly represented a deviation from the principle of equality of states, as there were existing states that due to the historical circumstances were not invited to participate at the Bretton Woods Conference and as a result acquire original membership.

The second condition requires participation at the Bretton Woods Conference. Participation in the Bretton Woods Conference was a possibility only for the countries fighting the Axis powers during World War II that received an invitation by the host state, the United States. In fact, all the countries invited to participate had either signed the Declaration of the United Nations of January 1, 1942 (Australia, Belgium, Canada, China, Costa Rica, Cuba, Czechoslovakia, Dominican Republic, El Salvador, Greece, Guatemala, Haiti, Honduras, India, Luxembourg, Netherlands, New Zealand, Nicara-

\footnotetext{
${ }^{858}$ Articles of Agreement of the International Monetary Fund, Article II, Section 1.

${ }^{859}$ Articles of Agreement of the International Monetary Fund, Article II, Section 1.

${ }^{860}$ See Joseph Gold, Membership and Nonmembership in the International Monetary Fund: a study in international law and organization, International Monetary Fund, 1974, pg. 44-45.
} 
gua, Norway, Panama, Poland, South Africa, U.S.S.R, UK, US and Yugoslavia) or that had not signed the Declaration on January 1, 1942 but that had adhered to the UN Declaration until July 1, 1944 (Bolivia, Brazil, Colombia, Ethiopia, Iran, Iraq, Liberia, Mexico, Philippines) or belong to the groups of countries that had broken their relations with the Axis powers and were helping the United Nations (Chile, Ecuador, Egypt, France, Iceland, Paraguay, Peru, Uruguay, Venezuela). ${ }^{861}$ This situation is very similar to the participation of states in the establishment of the UN. The division of states invited to participate at the San Francisco Conference was the same, as also the states establishing the United Nations belonged to the Allies of WWII. The Axis Powers such as Germany, Italy and Japan were not invited, nor was the majority of Africa (being colonized) eligible for membership. ${ }^{862}$

The third condition was to have signed the Articles of Agreement by December 31, 1945. This condition was met by the following 35 countries acquiring original member status: Belgium, Bolivia, Canada, China, Colombia, Czechoslovakia, Egypt, Ethiopia, France, Greece, Honduras, Iceland, India, Iraq, Luxembourg, Netherlands, Norway, Philippines, South Africa, United Kingdom, United States, Yugoslavia ${ }^{863}$, Dominican Republic, Ecuador, Guatemala, Paraguay, Iran Islamic Republic of (Iran), Chile, Mexico, Peru, Costa Rica, Poland, Brazil, Uruguay, and Cuba. ${ }^{864}$

With regard to the application of the principle of equality of states in the acquisition of original membership of the IMF, it is clear that the original countries had the opportunity to acquire membership only by participating in the negotiations. Participation in the negotiations was only available to countries that received invitations to participate at the Bretton Woods Conference. Due to a divided world at the time of the negotiations for the establishment of the IMF, some of the main contributors of the Fund are not original members (Germany, Japan, Russia, and Saudi Arabia). On the other hand, India and the Philippines although at the time were not independent states; acquired original membership of the IMF. No decision for admission was needed and no such decision was taken by any of the IMF organs as they were not yet established.

\footnotetext{
${ }^{861}$ Ibid., pg. 13.

${ }^{862}$ James M. Boughton, Silent Revolution: The International Monetary Fund, 1979-1989, The International Monetary Fund, 2001, pg. 964.

863 Note that Yugoslavia is not a member of the IMF as of December 14, 1992. It was succeeded by Croatia and Slovenia on January 15, 1993, Macedonia on April 21, 1993, Bosnia and Herzegovina on December 20, 1995 and the FR of Yugoslavia on December 20, 2000. The FR of Yugoslavia was renamed Serbia and Montenegro which eventually in 2006 separated to Serbia and Montenegro. Serbia succeeded the membership of Serbia and Montenegro. See IMF web site at: http://www.imf.org/external/np/sec/memdir/memdate.htm, (visited March, 2013).

${ }^{864}$ Note that original members are the countries that have signed the Articles of Agreement by December 31, 1945. The following countries signed the Article of Agreement by December 31, 1945, however their membership became effective upon the deposit of instruments of acceptance as follows: Costa Rica (January 8, 1946), Poland (January 10, 1946), Brazil (January 14, 1946), Uruguay (March 11, 1946), and Cuba (March 1946). The IMF website lists all these members as original member of the IMF; see the IMF web page at: http://www.imf.org/external/np/sec/memdir/memdate.htm, (visited March, 2013). Note that Gold does not state the above mentioned members as original members as their membership became effective after December 31, 1945, see Joseph Gold, Membership and Nonmembership in the International Monetary Fund: a study in international law and organization, International Monetary Fund, 1974.
} 
Except for the possibility to acquire original membership of the IMF, the countries that participated in the negotiations also had the opportunity to participate in the decisionmaking for the establishment of the Fund and influence the outcome. As will be seen in the following section, the "other members" were not in the same position to acquire membership of the IMF or to influence the establishment of the IMF as the main legal and institutional framework of the Fund was already established by the original members.

\section{ADMISSION OF NEW MEMBERS TO THE IMF}

Countries that had not joined the IMF as original countries can do so as "other members". This possibility so far has been used by even 153 countries (out of the existing 188) ${ }^{865}$ The last three to join were Kosovo and Tuvalu in 2009, and South Sudan in April 2012.

The admission of new members is based on Article II, section 2 which foresees admission of "other members". It states that:

"membership shall be open to other countries at such times and in accordance with such terms as may be prescribed by the Board of Governors. These terms, including the terms for subscriptions, shall be based on principles consistent with those applied to other countries that are already members. "\$66

\subsection{SUBSTANTIVE LAW ON ADMISSION}

Similar to Article XII of the WTO Agreement, Article II of the IMF Articles of Agreement does not provide detailed information for admission of new countries. It is obvious

\footnotetext{
${ }^{865}$ Other members (besides the 35 original members) of IMF as to March, 2013: El Salvador, Nicaragua, Panama, Denmark, Venezuela, Bolivia, Turkey, Italy , Syria, Lebanon, Australia, Finland, Austria, Thailand (Siam), Pakistan, Sri Lanka (Ceylon), Sweden, Myanmar (Burma), Japan, Germany, Jordan, Haiti , Indonesia, Israel, Afghanistan, Islamic Rep. of (Afghanistan) ,Korea ,Argentina, Vietnam, Ireland, Saudi Arabia, Sudan, Ghana, Malaysia, Tunisia, Morocco, Spain, Libya, Portugal, Nigeria, Lao People's Democratic Republic (Laos), New Zealand, Nepal, Cyprus, Liberia, Togo, Senegal, Somalia, Sierra Leone, Tanzania, Kuwait, Jamaica, Côte d'Ivoire (Ivory Coast), Niger, Burkina Faso, Cameroon, Central African Republic, Chad, Congo, Benin, Gabon, Mauritania, Trinidad and Tobago, Madagascar, Algeria, Mali, Uganda, Burundi, Congo, Democratic Republic of the (Zaire), Guinea, Rwanda, Malawi, Zambia, Singapore, Guyana, Indonesia, Gambia, Botswana, Lesotho, Malta, Mauritius, Swaziland, Yemen, Equatorial Guinea, Cambodia, Barbados, Fiji, Oman, Samoa (Western Samoa),Bangladesh, Bahrain, Qatar, United Arab Emirates, Romania, Bahamas, Grenada, Papua New Guinea, Comoros, Guinea-Bissau, Seychelles, São Tomé and Príncipe, Maldives, Suriname, Solomon Islands, Cape Verde, Dominica, Djibouti, St. Lucia, St. Vincent and the Grenadines, Zimbabwe, Bhutan, Vanuatu, Antigua and Barbuda, Belize, Hungary, St. Kitts and Nevis, Mozambique, Tonga, Kiribati, Poland, Angola, Yemen, Czechoslovakia, Bulgaria, Namibia, Mongolia, Albania, Lithuania, Georgia, Kyrgyz Republic (Kyrgyzstan), Latvia, Marshall Islands, Estonia, Armenia, Switzerland, Russian Federation, Belarus, Kazakhstan, Moldova, Ukraine, Azerbaijan, Uzbekistan, Turkmenistan, San Marino, Bosnia and Herzegovina, Croatia, Macedonia- former Yugoslav Republic, Slovenia, Serbia, Czech Republic, Slovak Republic, Tajikistan, Micronesia, Eritrea, Brunei, Palau, Timor-Leste (East Timor), Montenegro, Kosovo, Tuvalu, and South Sudan.

${ }^{866}$ See Articles of Agreement of the International Monetary Fund, Article II, Section 2.
} 
from its wording that membership is an opportunity for countries based on terms subscribed by the plenary organ of the IMF, the Board of Governors. ${ }^{867}$

Therefore, there are primarily two main conditions for joining the IMF: first, that the applicant should be a country and second, that it joins the organization based on the terms prescribed.

With regard to the first condition, that the applicant is a country, the provision does not provide much detail. As mentioned in the previous section on original members, there were specific reasons why the term "countries" instead of the term "states" was used in the IMF. Moreover, unlike the United Nations requirement for the applicant state to be "peace loving", the IMF does not have such a condition. This did not mean that there were no sentiments among countries that the IMF should keep its door closed for the former enemy states. For example, in one of the drafts of the "White Plan" regarding the purposes of the Stabilization Fund, it was stated that the organization will only apply to the countries being part of the United Nations, or, the allies fighting the Axis powers. In these lines, in determining the purposes of the Stabilization Fund, White noted that they aim to stabilize exchange rates of the "United Nations", encourage flow of capital among the "United Nations", correct "maldistribution of gold among the United Nations" ${ }^{868}$ This clearly meant that non United Nations countries were not foreseen in the organization. This position however, was changed in the subsequent draft where the words "United Nations" were deleted. Similar sentiments existed among other states as well. Norway for example unsuccessfully proposed that Germany and Japan should not be admitted to the IMF nor the IBRD until admitted to the "political world organization" to be established (the United Nations). ${ }^{869}$

Eventually, having in mind the universal character of the Fund, with some delay, the former Axis powers were allowed to join the IMF. Italy joined in 1947 and Germany with Japan in $1952 .{ }^{870}$

In addition to the former enemy states of the Axis powers, the IMF was also facing another difficulty in the admission of new countries. Namely, although the USSR participated in the Bretton Woods Conference and was listed in Schedule A, it did not become an original member nor applied for admission. Neither did the majority of states that were part of the socialist block. ${ }^{871}$ China although a member of the Fund, was

${ }^{867}$ Fearing political considerations, the drafters of the Articles of Agreement entitled the Board of Governors to decide whether to admit or not new members in the IMF. See Joseph Gold, Membership and Nonmembership in the International Monetary Fund: a study in international law and organization, International Monetary Fund, 1974.

${ }^{868}$ See Part I, A, I, Points 1, 2, 4 of the "Preliminary Draft Proposal for a United Nations Stabilization Fund and a Bank for Reconstruction and Development of the United and Associated Nations” of April 1942.

${ }^{869}$ In similar terms, Yugoslavia questioned the application of Italy to join the Fund due to the fact that Italy as a former enemy country had not yet signed a peace treaty. See Joseph Gold, Membership and Nonmembership in the International Monetary Fund: a study in international law and organization, International Monetary Fund, 1974, pg. 17, 71-76.

${ }^{870}$ IMF web page at http://www.imf.org/external/np/exr/chron/chron.asp, (visited March 2013).

${ }^{871}$ See A. Schüller and H. Hamel, Of the Membership of Socialist Countries in the International Monetary Fund, 34 Acta Oeconomica 113 (1985). From the existing socialist countries, until 1985 only Hungary, Romania, Vietnam, Afghanistan, Cambodia, China, Korea, Laos, Yemen and Yugoslavia had joined the IMF. 
represented by the Nationalist government based in Taiwan (with no control over the mainland); Poland was forced to withdraw under Soviet pressure in 1950 and Czechoslovakia was forced to withdraw leaving Yugoslavia as the only IMF member belonging to the socialist block. ${ }^{872}$ This division of countries also prevented universality of membership for a long time and ended after the fall of the Berlin Wall in 1989. Finally Russia joined the IMF in 1992 together with 13 (out of 14) former Socialist states. It was obvious that due to the historical context of World War II and of the Cold War, universality was not possible to achieve.

The second condition with regard to the terms prescribed by the Board of Governors (including subscription terms) there are two aspects to consider. First, similar to the WTO, it is the IMF that prescribes the conditions for admission, including the quota and voting rights and not much room is available for negotiating. Second, the provision states that they should be consistent with the ones applied to existing members. Such a provision determining the terms of subscription based on the existing members is in line with the principle of equality of states. The WTO does not have such a provision (except on LDC's).

Although the terms envisaged should be consistent with the ones applied to existing members, the difficulty with the application of the principle of equality of states rests in the established system of the IMF based on weighted voting. Namely, upon joining the IMF, each new member is assigned a quota which determines the position of the member in the IMF financial and organizational issues such as subscriptions (finances obligated to provide to the IMF), voting power (primarily based on the quota), access to financing (financing it can obtain from IMF) and SDR allocations (reserve assets). ${ }^{873}$ The quota assigned to the new member determines also the position and the power of the member in relation to other members of the IMF and its position to influence IMF policies. The greater the economic power of the member, the greater the quota and the voting power is. Such a situation creates inequality between members as some members are not only de facto but also de jure in a better position in the IMF governance structure.

\subsection{PROCEDURAL LAW ON ADMISSION}

IMF Bylaws stipulate that any country may apply for membership in the Fund by sending an application that contains all the relevant facts. ${ }^{874}$ The responsible body to facilitate the membership application is the Executive Board which is obliged to report on all application to the Board of Governors. According to the Rules and Regulations of the IMF, the application for membership is promptly placed before the Executive Board.

\footnotetext{
${ }^{872}$ James M. Boughton, Silent Revolution: The International Monetary Fund, 1979-1989, The International Monetary Fund, 2001, pg. 963-964.

${ }^{873}$ See IMF web page at: http://www.imf.org/external/about/members.htm, (visited march 2013).

${ }^{874}$ Section 21, (a) of the By-Laws of the International Monetary Fund, Adopted March 16, 1946, amended June 13, 1978.
} 
The Executive Board having had reasonable time for discussions and investigation; decides whether to submit the application to the Board of Governors. ${ }^{875}$ In these lines, Section 21 (b) of the By-Laws, states that the:

"Executive Board shall report on all applications to the Board of Governors. When an application is submitted to the Board of Governors with a recommendation that the applicant country be admitted to membership, the Executive Board after consultation with the applicant country shall recommend to the Board of Governors the amount of the quota, the form of payment of the subscription, and such other conditions as, in the opinion of the Executive Board, the Board of Governors may wish to prescribe. "876

The decision for admission is adopted by a majority of the votes cast and there is no difference between the original and the admitted members in the decision whether or not to admit a new member. ${ }^{877}$ From what it is stated above, it is the Board of Governors that decides on admission, although the Executive Board is in charge for the day to day implementation of the process and has some important authority, such as to recommend the amount of quota, subscription payment and other conditions it considers fit for the Board of Governors to prescribe.

With regard to the principle of equality of states, the fact that it is the plenary body of the IMF (Board of Governors) that decides on the admission of new countries at first sight may seem to be in compliance with the principle of equality of states. However, as it will be seen, the Board of Governors has a weighted voting system which results in unequal voting power of its members and a deviation from the principle of equality of states. IMF members do not have equal say in the admission decision-making process, are not equally represented and have different voting powers. Moreover, the fact that the Executive Board, the non plenary body, has the authority to recommend the amount of quota, subscription payment and other conditions it considers fit for the Board of Governors to prescribe, also represents a deviation from the principle of equality of states.

\section{ACQUISITION OF MEMBERSHIP IN THE IMF AND THE PRINCIPLE OF EQUALITY OF STATES}

With regard to the application of the principle of equality of states in acquisition of membership in the IMF, it is obvious that a number of issues are of importance.

\footnotetext{
${ }^{875}$ Rules and Regulations of the International Monetary Fund, section D.

${ }^{876}$ Section 21, (b) of the By-Laws of the International Monetary Fund, Adopted March 16, 1946, amended June 13, 1978.

${ }^{877}$ Not requiring special types of majority votes in admission shows the position of the drafters in favour of enlarged membership; see Joseph Gold, Membership and Nonmembership in the International Monetary Fund: a study in international law and organization, International Monetary Fund, 1974, pg. 30-31. Note that there are IGOs (as mentioned in Chapter II, above, pg. 87-90) like OPEC that require for the concurrent votes of the founders of the organization for any admissions to take place.
} 
First, in the pre Bretton Woods phase, it was obvious that the main negotiations were conducted between the United States and the United Kingdom. The role and the position of the United States was central, and therefore greater focus was given to the "White Plan" in comparison to the "Keynes Plan". An opportunity for consultations was provided to France and Canada in particular, and to a limited number of states in the Atlantic City Conference to influence the preparations for the Bretton Woods Conference.

Second, at the Bretton Woods Conference participation was an opportunity only to the countries invited by the United States. Such an opportunity was provided only for the United Nations, the Associated Powers and the countries in close relations to them. No invitations were extended to the Axis powers. The countries participating in the Bretton Woods conference had an opportunity to be part of the decision-making for the establishment of the IMF and to acquire original membership. They were entitled to original membership and the IMF could not reject their membership based on grounds that they do not fulfil membership criteria, something that the Fund can do when it comes to the "other members". ${ }^{878}$ Such an option was not possible for any other country not being invited to the Bretton Woods Conference. This was not in coherence with the principle of equality of states. The establishment of a universal international organization should be an opportunity for all interested states to participate equally in the negotiations and the decision-making process. The fact that this was done during World War II was very unfortunate and did not make it plausible for all states to participate.

Third, the Bretton Woods Conference was central to the adoption of a weighted model of decision-making and a management structure of limited representation of membership. These decisions were reflected in the Articles of Agreement of the Fund and as such represent a deviation from the principle of equality of states.

Fourth, all the "other members" were able to apply for membership in the IMF, including the former enemy states, Russia and other former socialist states. Eventually, they all became IMF members. Keeping an open door policy for new members in an organization of a universal character is in line with the principle of equality of states.

Fifth, the weighed system used to assign quota shares for new members, represents an underlying deviation from the principle of equality of states.

Sixth, the fact that the plenary body of the IMF, the Board of Governors decides on admissions of new members is in line with the principle of equality of states when it comes to representation of members. However, the decision for admission of new members adopted by a majority of votes in the Board of Governors is a deviation from the principle of equality of states due to the weighed voting system.

\footnotetext{
${ }^{878}$ See Joseph Gold, Membership and Nonmembership in the International Monetary Fund: a study in international law and organization, International Monetary Fund, 1974, pg. 41.
} 


\section{DECISION-MAKING IN THE IMF}

Article XII of the Articles of the Agreement sets the basic structure of governance of the IMF ${ }^{879}$ The governing bodies of the IMF are: the Board of Governors, the Executive Board and the Managing Director and a staff. It is considered that:

"the manner in which member countries interact with the IMF, and in which the Executive Board, the Managing Director, and the staff work together in conducting the IMF's business are key elements in its governance". 880

The principal powers of the IMF are vested in the Board of Governors, the plenary body of the IMF; although de facto the Executive Board is the most important body due to the fact that the Board of Governors delegates most of its decision powers to the Executive Board. The Managing Director is the Chairman of the Executive Board and oversees the International Monetary Fund ordinary business. ${ }^{881}$ The IMF's governance structure is considered to be an attempt to achieve a balance between the operational needs to effectively manage a financial institution and universal representation. ${ }^{882}$

This section discusses the application of the principle of equality of states with regard to the: (1) weighted voting system; (2) majority or consensus decision-making; (3) Board of Governors; (4) Executive Board; Managing Director and Staff; (5) reform of the IMF.

\section{WHEIGHTED VOTING IN THE IMF}

With regard to the weighted voting system, the Articles of Agreement provide for a decision-making which is essentially based on a model of weighted power. All IMF members have a weighted voting power which is calculated based on the: 1) quota share; 2) basic votes; and the 3) voting power (which equals the total of the quota and the basic votes). These elements of the weighted voting system in the IMF will be discussed in more detail in this section.

\footnotetext{
${ }^{879}$ See Articles of Agreement of the International Monetary Fund, Article XII. This provision is divided into 8 Sections out of which the most relevant for the governance of the IMF are Sections 1-5 dealing with the Structure of the Fund, the Board of Governors, the Executive Board, the Managing Director and staff and Voting.

${ }^{880}$ Leo Van Houtven, Governance of the IMF: Decision-making, Institutional Oversight, Transparency, and Accountability, Pamphlet Series No. 53, International Monetary Fund, 2002, pg. 11.

${ }^{881}$ Articles of Agreement of the International Monetary Fund, Article XII, Section 3, (b).

${ }^{882}$ Financial Organization and Operations of the IMF, Treasurer's Department, International Monetary Fund 2001, IMF Pamphlet Series No. 45, Sixth Edition, Treasurer's Department, International Monetary Fund, 2001, pg. 3.
} 


\subsection{THE QUOTA}

The quota ${ }^{883}$ is assigned on the basis of predetermined criteria. Members are allocated quotas (expressed in millions of SDRs), based upon the size of the particular economy, participation in world trade and various other factors, such as political influence, which may have a bearing. The original Bretton Woods formula included components of national incomes, external trade, reserves and export fluctuations; in the 1960s the formula took into consideration different weights for national income and current external payments and variability of current receipts and since the 1980s the formula included GNP, official reserves, external payments and receipts, variability of current receipts and their ratio to GNP. ${ }^{884}$ The formulas for the calculation of quotas are considered to be essentially arbitrary and over the years have been adjusted. ${ }^{885}$

The difference with regard to the quota share and the voting power of IMF members at the initial stages of IMF's development was its highest peak. In 1947 the IMF had 44 members which included a totality of quota shares amounting to 7.721 .5 (in millions of US \$) and 88.215 of votes. The United States had around 1/3 of the total votes (equal in proportion to around 15 members) out of the existing 44 if equal voting powers would have applied at the time. Moreover, the 10 most powerful members together controlled around $78.27 \%$ of the votes while the remaining 34 members together controlled around $21.73 \%$ of the total votes. ${ }^{886}$

The following table provides specific data on the quota and votes of 10 largest shareholders in 1947.

Table 6: Quota share and voting power of the 10 largest and the remaining 34 IMF members in 1947

\begin{tabular}{|c|c|c|}
\hline Country & Quota & Votes \\
\hline United States & 2,750 or $35.61 \%$ & 27,750 or $31.45 \%$ \\
\hline United Kingdom & 1,300 or $16.83 \%$ & 13,250 or $15.02 \%$ \\
\hline China & 550 or $7.12 \%$ & 5,750 or $\quad 6.51 \%$ \\
\hline France & 525 or $6.79 \%$ & 5,500 or $6.23 \%$ \\
\hline India & 400 or $5.18 \%$ & 4,250 or $4.82 \%$ \\
\hline Canada & 300 or $3.88 \%$ & 3,250 or $3.68 \%$ \\
\hline Netherlands & 275 or $3.56 \%$ & 3,000 or $3.4 \%$ \\
\hline Belgium & 225 or $2.91 \%$ & 2,500 or $2.83 \%$ \\
\hline Italy & 180 or $2.33 \%$ & 2,050 or $2.32 \%$ \\
\hline
\end{tabular}

${ }^{883}$ Articles of Agreement of the IMF, Article III, Section 1 states "Each member shall be assigned a quota expressed in special drawing rights."

${ }^{884}$ Leo Van Houtven, Governance of the IMF: Decision-making, Institutional Oversight, Transparency, and Accountability, Pamphlet Series No. 53, International Monetary Fund, 2002, pg. 5.

${ }^{885}$ Randall W. Stone, Controlling Institutions: International Organizations and the Global Economy, Cambridge University Press, 2011, pg. 53.

${ }^{886}$ Estimates based from the data provided by the UN Yearbook 1946/47, Part II, Chapter VI, The International Monetary Fund, pg. 769-770. available at: http://unyearbook.un.org/unyearbook.html?name=194647index.html, (visited March, 2013). 


\begin{tabular}{llr} 
Brazil & 150 or $1.94 \%$ & 1,750 or $1.98 \%$ \\
Total & 6,655 or $86.18 \%$ & 69,050 or $78.27 \%$ \\
Remaining 34 IMF Members & 1066,5 or $13.82 \%$ & 19165 or $21.73 \%$ \\
\hline
\end{tabular}

This division can be better illustrated in the following chart:

Chart 12: A comparison in quota shares and voting power between the 10 largest members and the remaining 34 in \%



The chart shows a very significant difference and also no mathematical equality between the quota provided by the members and their voting rights as the former is higher than the latter. This is the result of the fact that the quota share of the individual members, although a central indicator for the determination of the voting power of individual IMF members, is not the only indicator determining the voting powers of IMF members. Furthermore, it should be noted that the quota shares of the IMF members are dynamic and tend to change over time. Usually every five years, the Board of Governors conducts a review of the quotas. If there is majority of $85 \%$ of the total votes, then decisions on quota changes are adopted. From the establishment of the IMF, there have been fourteen reviews of quota shares, out of which many resulted in their amendment. The following table presents for information on changes of quotas in the IMF. ${ }^{887}$

\footnotetext{
${ }^{887}$ See IMF Web site at: http://www.imf.org/external/np/exr/facts/quotas.htm, (visited March, 2013)
} 
Table 7: The changes of the total quota shares in the IMF

\begin{tabular}{lll}
\hline Quota Review & Resolution Adopted & Overall Quota Increase in \% \\
\hline First Quinquennial & No increase proposed & --- \\
Second Quinquennial & No increase proposed & --- \\
1958/59 & February and April 1959 & 60.7 \\
Third Quinquennial & No increase proposed & --- \\
Fourth Quinquennial & March 1965 & 30.7 \\
Fifth General & February 1970 & 35.4 \\
Sixth General & March 1976 & 33.6 \\
Seventh General & December 1978 & 50.9 \\
Eighth General & March 1983 & 47.5 \\
Ninth General & June 1990 & 50.0 \\
Tenth General & No increase proposed & --- \\
Eleventh General & January 1998 & 45.0 \\
Twelfth General & No increase proposed & --- \\
Thirteenth General & No increase proposed & --- \\
Fourteenth General & December 2010 & 100.0 \\
\hline
\end{tabular}

The scope of quota changes is relatively limited as the increase of the quota shares and the votes of one member, automatically reduces the voting power of the rest of the members. ${ }^{888}$

The existing formula for the determination of quota shares of individual IMF members represents: a weighted average of GDP (weight of $50 \%$ ), openness (30\%), economic variability (15\%, and international reserves $(5 \%){ }^{889}$ As a result, all IMF members have their allocation of quota shares. The current 188 members of the IMF in March 2013 amounted to around SDR 238.4 billion in total. The following table presents the current individual share of quotas of IMF members.

\footnotetext{
${ }^{888}$ Leo Van Houtven, Governance of the IMF: Decision-making, Institutional Oversight, Transparency, and Accountability, Pamphlet Series No. 53, International Monetary Fund, 2002, pg. 6.

${ }^{889}$ See for details IMF web site at: http://www.imf.org/external/np/exr/facts/quotas.htm, (visited March 2013).
} 
Table 8: Quota share of IMF members in \%

\begin{tabular}{|c|c|c|}
\hline 1 & United States & 17.69 \\
\hline 2 & Japan & 6.56 \\
\hline 3 & Germany & 6.12 \\
\hline 4 & France & 4.51 \\
\hline 5 & United Kingdom & 4.51 \\
\hline 6 & China & 4 \\
\hline 7 & Italy & 3.31 \\
\hline 8 & Saudi Arabia & 2.93 \\
\hline 9 & Canada & 2.67 \\
\hline 10 & Russia & 2.5 \\
\hline 11 & India & 2.44 \\
\hline 12 & Netherlands & 2.17 \\
\hline 13 & Belgium & 1.93 \\
\hline 14 & Brazil & 1.79 \\
\hline 15 & Spain & 1.69 \\
\hline 16 & Mexico & 1.52 \\
\hline 17 & Switzerland & 1.45 \\
\hline 18 & Korea & 1.41 \\
\hline 19 & Australia & 1.36 \\
\hline 20 & Venezuela & 1.12 \\
\hline 21 & Sweden & 1.01 \\
\hline 22 & Argentina & 0.89 \\
\hline 23 & Austria & 0.89 \\
\hline 24 & Indonesia & 0.87 \\
\hline 25 & Denmark & 0.79 \\
\hline 26 & Norway & 0.79 \\
\hline 27 & South Africa & 0.78 \\
\hline 28 & Malaysia & 0.74 \\
\hline 29 & Nigeria & 0.74 \\
\hline 30 & Poland & 0.71 \\
\hline 31 & Iran, Islamic Republic of & 0.63 \\
\hline 32 & Turkey & 0.61 \\
\hline 33 & Thailand & 0.6 \\
\hline 34 & Singapore & 0.59 \\
\hline 35 & Kuwait & 0.58 \\
\hline 36 & Ukraine & 0.58 \\
\hline 37 & Algeria & 0.53 \\
\hline 38 & Finland & 0.53 \\
\hline
\end{tabular}

\begin{tabular}{|c|c|c|}
\hline 39 & Ireland & 0.53 \\
\hline 40 & Iraq & 0.5 \\
\hline 41 & Libya & 0.47 \\
\hline 42 & Greece & 0.46 \\
\hline 43 & Israel & 0.45 \\
\hline 44 & Hungary & 0.44 \\
\hline 45 & Pakistan & 0.43 \\
\hline 46 & Philippines & 0.43 \\
\hline 47 & Portugal & 0.43 \\
\hline 48 & Romania & 0.43 \\
\hline 48 & Czech Republic & 0.42 \\
\hline 50 & Egypt & 0.4 \\
\hline 51 & New Zealand & 0.38 \\
\hline 52 & Chile & 0.36 \\
\hline 53 & Colombia & 0.33 \\
\hline 54 & United Arab Emirates & 0.32 \\
\hline 55 & Bulgaria & 0.27 \\
\hline 56 & Peru & 0.27 \\
\hline 57 & Morocco & 0.25 \\
\hline 58 & Bangladesh & 0.22 \\
\hline 59 & Congo & 0.22 \\
\hline 60 & Zambia & 0.21 \\
\hline 61 & Serbia & 0.2 \\
\hline 62 & Vietnam & 0.19 \\
\hline 63 & Luxembourg & 0.18 \\
\hline 64 & Slovak Republic & 0.18 \\
\hline 65 & Sri Lanka & 0.17 \\
\hline 66 & Belarus & 0.16 \\
\hline 67 & Croatia & 0.15 \\
\hline 68 & Ecuador & 0.15 \\
\hline 69 & Ghana & 0.15 \\
\hline 70 & Kazakhstan & 0.15 \\
\hline 71 & Zimbabwe & 0.15 \\
\hline 72 & Côte d'Ivoire & 0.14 \\
\hline 73 & Trinidad and Tobago & 0.14 \\
\hline 74 & Qatar & 0.13 \\
\hline 75 & Uruguay & 0.13 \\
\hline 76 & Angola & 0.12 \\
\hline
\end{tabular}




\begin{tabular}{|c|c|c|}
\hline 77 & Slovenia & 0.12 \\
\hline 78 & Syria & 0.12 \\
\hline 79 & Tunisia & 0.12 \\
\hline 80 & Uzbekistan & 0.12 \\
\hline 8 & Jamaica & 0.11 \\
\hline 82 & Kenya & 0.11 \\
\hline 83 & Lebanon & 0.11 \\
\hline 84 & Myanmar & 0.11 \\
\hline 85 & Oman & 0.1 \\
\hline 86 & Yemen & 0.1 \\
\hline 87 & Brunei Darussalam & 0.09 \\
\hline 88 & Dominican Republic & 0.09 \\
\hline 89 & Guatemala & 0.09 \\
\hline 90 & Panama & 0.09 \\
\hline 91 & Cameroon & 0.08 \\
\hline 92 & Lithuania & 0.08 \\
\hline 93 & Tanzania & 0.08 \\
\hline 94 & Uganda & 0.08 \\
\hline 95 & Afghanistan & 0.07 \\
\hline$\overline{96}$ & Azerbaijan & 0.07 \\
\hline 97 & Bolivia & 0.07 \\
\hline 98 & Bosnia & 0.07 \\
\hline 99 & Costa Rica & 0.07 \\
\hline$\overline{100}$ & Cyprus & 0.07 \\
\hline 101 & El Salvador & 0.07 \\
\hline 102 & Jordan & 0.07 \\
\hline 103 & Senegal & 0.07 \\
\hline 104 & Sudan & 0.07 \\
\hline 105 & Bahrain & 0.06 \\
\hline 106 & Gabon & 0.06 \\
\hline 107 & Georgia & 0.06 \\
\hline 108 & Latvia & 0.06 \\
\hline 109 & Namibia & 0.06 \\
\hline 110 & Papua New Guinea & 0.06 \\
\hline 111 & Bahamas, & 0.05 \\
\hline 112 & Honduras & 0.05 \\
\hline 113 & Iceland & 0.05 \\
\hline 114 & Liberia & 0.05 \\
\hline 115 & Madagascar & 0.05 \\
\hline
\end{tabular}

\begin{tabular}{|c|c|c|}
\hline 116 & Moldova & 0.05 \\
\hline 117 & Mozambique & 0.05 \\
\hline 118 & Nicaragua & 0.05 \\
\hline 119 & South Sudan & 0.05 \\
\hline 120 & Armenia & 0.04 \\
\hline 121 & Botswana & 0.04 \\
\hline 122 & Cambodia & 0.04 \\
\hline 123 & Congo & 0.04 \\
\hline 124 & Estonia & 0.04 \\
\hline 125 & Guinea & 0.04 \\
\hline 126 & Guyana & 0.04 \\
\hline 127 & Kyrgyz Republic & 0.04 \\
\hline 128 & Mali & 0.04 \\
\hline 129 & Malta & 0.04 \\
\hline 130 & Mauritius & 0.04 \\
\hline 131 & Paraguay & 0.04 \\
\hline 132 & Sierra Leone & 0.04 \\
\hline 133 & Suriname & 0.04 \\
\hline 134 & Tajikistan & 0.04 \\
\hline 135 & Albania & 0.03 \\
\hline 136 & Barbados & 0.03 \\
\hline 137 & Benin & 0.03 \\
\hline 138 & Burkina Faso & 0.03 \\
\hline 139 & Burundi & 0.03 \\
\hline 140 & Chad & 0.03 \\
\hline 141 & Fiji, Republic of & 0.03 \\
\hline 142 & Haiti & 0.03 \\
\hline 143 & Macedonia & 0.03 \\
\hline 144 & Malawi & 0.03 \\
\hline 145 & Mauritania & 0.03 \\
\hline 146 & Nepal & 0.03 \\
\hline 147 & Niger & 0.03 \\
\hline 148 & Rwanda & 0.03 \\
\hline 149 & Togo & 0.03 \\
\hline 150 & Turkmenistan & 0.03 \\
\hline$\overline{151}$ & Central African Republic & 0.02 \\
\hline 152 & Equatorial Guinea & 0.02 \\
\hline 153 & Kosovo & 0.02 \\
\hline 154 & Lao & 0.02 \\
\hline
\end{tabular}




\begin{tabular}{|c|c|c|}
\hline 155 & Mongolia & 0.02 \\
\hline 156 & Somalia & 0.02 \\
\hline 157 & Swaziland & 0.02 \\
\hline 158 & Antigua and Barbuda & 0.01 \\
\hline 159 & Belize & 0.01 \\
\hline 160 & Djibouti & 0.01 \\
\hline 161 & Eritrea & 0.01 \\
\hline 162 & Gambia, The & 0.01 \\
\hline 163 & Guinea-Bissau & 0.01 \\
\hline 164 & Lesotho & 0.01 \\
\hline 165 & Montenegro & 0.01 \\
\hline 166 & San Marino & 0.01 \\
\hline 167 & St. Lucia & 0.01 \\
\hline$\overline{168}$ & Vanuatu & 0.01 \\
\hline 169 & Ethiopia & 0.006 \\
\hline 170 & Cape Verde & 0.005 \\
\hline 171 & Grenada & 0.005 \\
\hline
\end{tabular}

\begin{tabular}{|c|c|c|}
\hline 172 & Samoa & 0.005 \\
\hline 173 & Seychelles & 0.005 \\
\hline 174 & Comoros & 0.004 \\
\hline 175 & Maldives & 0.004 \\
\hline 176 & Solomon Isl. & 0.004 \\
\hline 177 & St.Kitts \& Nevis & 0.004 \\
\hline 178 & Bhutan & 0.003 \\
\hline 179 & Dominica & 0.003 \\
\hline 180 & São Tomé and Prí. & 0.003 \\
\hline 181 & St. Vinc. \& Gren. & 0.003 \\
\hline 182 & Timor-Leste & 0.003 \\
\hline 183 & Tonga & 0.003 \\
\hline 184 & Kiribati & 0.002 \\
\hline 185 & Micronesia & 0.002 \\
\hline 186 & Marshall Islands & 0.001 \\
\hline 187 & Palau & 0.001 \\
\hline 188 & Tuvalu & 0.001 \\
\hline
\end{tabular}

This data ${ }^{890}$ shows very sharp differences between members in their quota allocation. For example, the 100 IMF members having the smallest shares of quota together have around $3.407 \%$ of the quota share while the remaining 88 IMF members around 96.693 $\%$ of the quota share. If these 100 smallest quota share holders are compared to the greatest shareholder, the United States with $17.69 \%$ of the quota, it is obvious that the US alone has a quota representation which equals around 5 times the existing 100 smallest shareholder. The ratio is 1:500. Another difference is that the 10 greatest shareholders have $54.8 \%$ of the quota, while the remaining 178 IMF members have $55.2 \%$.

If the quota share of the $27 \mathrm{EU}$ Members States is compared to the remaining 161 IMF members, the difference is also very significant. ${ }^{891}$

Table 9: Quota shares of EU member states in the IMF

\begin{tabular}{lll}
\hline IMF MEMBER & MILLIONS OF SDR'S & \% OF TOTAL \\
\hline Austria & $2,113.90$ & 0.89 \\
Belgium & $4,605.20$ & 1.93 \\
Bulgaria & 640.2 & 0.27 \\
Cyprus & 158.2 & 0.07 \\
Czech Republic & $1,002.20$ & 0.42 \\
Denmark & $1,891.40$ & 0.79 \\
Estonia & 93.9 & 0.04
\end{tabular}

${ }^{890}$ Based on estimates provided on the IMF web site at: http://www.imf.org/external/np/sec/memdir/members.aspx, (visited March 2013).

${ }^{891}$ Ibid. 


\begin{tabular}{lll} 
Finland & $1,263.80$ & 0.53 \\
France & $10,738.50$ & 4.51 \\
Germany & $14,565.50$ & 6.12 \\
Greece & $1,101.80$ & 0.46 \\
Hungary & $1,038.40$ & 0.44 \\
Ireland & $1,257.60$ & 0.53 \\
Italy & $7,882.30$ & 3.31 \\
Latvia & 142.1 & 0.06 \\
Lithuania & 183.9 & 0.08 \\
Luxembourg & 418.7 & 0.18 \\
Malta & 102 & 0.04 \\
Netherlands & $5,162.40$ & 2.17 \\
Poland & $1,688.40$ & 0.71 \\
Portugal & $1,029.70$ & 0.43 \\
Romania & $1,030.20$ & 0.43 \\
Slovak Republic & 427.5 & 0.18 \\
Slovenia & 275 & 0.12 \\
Spain & $4,023.40$ & 1.69 \\
Sweden & $2,395.50$ & 1.01 \\
United Kingdom & $10,738.50$ & 4.51 \\
Total EU Members & 75970.2 & $31.92 \%$ \\
\hline
\end{tabular}

The 27 EU Members States have $31.92 \%$ of the quota share compared to the remaining 161 IMF members having $69.8 \%$ of the total quota share. As a result of these sharp differences, the developing country members of the IMF have urged for a quota formula that would include elements such as population and poverty index in order to enhance their voice in the IMF. ${ }^{892}$

\subsection{THE BASIC VOTES}

The quota is the most important, although not the only component determining the voting power of IMF Members. The second component are the so called basic votes. The basic votes are the votes that each member is entitled to by acquiring membership in the IMF. ${ }^{893}$ In line with the principle of equality of states, each member receives 250 basic votes. Basic votes are based on the idea of the principle of equality of states and resemble the United Nations system of one country one vote. The difficulty with the application of the principle of equality of states here is that the basic votes represent just a small portion of the total votes. In fact, although the percentage of basic votes varied in time, the general trend (except with the latest IMF reforms) overall has been in favor of sharp decline of the percentage of basic votes. As the percentage of quotas grew, the

${ }^{892}$ Leo Van Houtven, Governance of the IMF: Decision-making, Institutional Oversight, Transparency, and Accountability, Pamphlet Series No. 53, International Monetary Fund, 2002, pg. 7.

${ }^{893}$ Articles of Agreement of the IMF, Article XII, Section 5 (i). 
percentage of basic votes melted. With it also the "percentage" of application of the principle of equality of states in the voting power of individual members. For example, basic votes accounted for $11.3 \%$ of total votes in 1945, they reached their peak in 1958 with $15.6 \%$, after that period there was a decrease although until the 1970's remained above $10 \%$, to fluctuate to barely $2 \%$ in 2002 , or $2.1 \%$ in $2007 .{ }^{894}$

The latest effective reform of 2008 in the IMF almost tripled the share of basic votes to $5.502 \%$ which of course, represents an important (although not sufficient) support to enhance the equality of IMF members. This difference can be better illustrated in the following chart:

${ }^{894}$ See Andreas F. Lowenfeld, International Economic Law, Second Edition, Oxford University Press, 2008 , pg. 603 and Leo Van Houtven, Governance of the IMF: Decision-making, Institutional Oversight, Transparency, and Accountability, Pamphlet Series No. 53, International Monetary Fund, 2002, pg. 6. 




As stated, the decline in the importance of basic votes was a result of the repeated increases of the Fund's quotas, which had a much larger effect on the voting structure than the increases in the number of members. This decline exemplifies the lack of meaningful participation of the weaker economies. The erosion of this minimum safe guard over the years exemplifies the lack of the respect for the equality of states.

\subsection{THE VOTING POWER}

Based on the quota share and the initial 250 basic votes, the voting power of every member is determined. Every member receives additional vote per 100000 SDR of its quota. ${ }^{895}$ Therefore, the greater the quota, the greater the financial responsibility of the members but most importantly, the greater the voting power.

The unequal voting power varies over time as member states quota subscriptions are periodically adjusted to reflect changing economic realities.

In other words, the distribution of the quotas is intended to reflect the relative economic importance of member countries, and their capacity to contribute financial resources required by the Fund. ${ }^{896}$

\footnotetext{
${ }^{895}$ Articles of Agreement of the IMF, Article II, Section 5(a).

${ }^{896}$ Such a system of weighted voting except in the IMF and the World Bank can also be seen in regional development banks such as the: African Development Bank, Asian Development Bank, Caribbean Development Bank. However, in these banks the weighted voting seem to be more in line with the principle of
} 
After having established the quota \% and the basic votes of individual IMF members it is important to see how this is reflected in the voting power. ${ }^{897}$

equality of states as the difference in votes is not that significant as in the IMF and the WB. See Henry G. Schermers \& Niels M. Blokker, International Institutional Law, Fifth Revised Edition, Martinus Nijhoff Publishers, 2011, pg. 554.

${ }^{897}$ Based on estimates provided on the IMF web site at: http://www.imf.org/external/np/sec/memdir/members.aspx, (visited March 2013). 
Table 10: The \% of votes of individual IMF members

\begin{tabular}{|c|c|c|}
\hline 1 & United States & 16.75 \\
\hline 2 & Japan & 6.23 \\
\hline 3 & Germany & 5.81 \\
\hline 4 & France & 4.29 \\
\hline 5 & UK & 4.29 \\
\hline 6 & China & 3.81 \\
\hline 7 & Italy & 3.16 \\
\hline 8 & Saudi Arabia & 2.8 \\
\hline 9 & Canada & 2.56 \\
\hline 10 & Russia & 2.39 \\
\hline 11 & India & 2.34 \\
\hline 12 & Netherlands & 2.08 \\
\hline 13 & Belgium & 1.86 \\
\hline 14 & Brazil & 1.72 \\
\hline 15 & Spain & 1.63 \\
\hline 16 & Mexico & 1.47 \\
\hline 17 & Switzerland & 1.4 \\
\hline 18 & Korea & 1.37 \\
\hline 19 & Australia & 1.31 \\
\hline 20 & Venezuela & 1.08 \\
\hline 21 & Sweden & 0.98 \\
\hline 22 & Argentina & 0.87 \\
\hline 23 & Austria & 0.87 \\
\hline 24 & Indonesia & 0.85 \\
\hline 25 & Denmark & 0.78 \\
\hline 26 & Norway & 0.78 \\
\hline 27 & South Africa & 0.77 \\
\hline 28 & Malaysia & 0.73 \\
\hline 29 & Nigeria & 0.73 \\
\hline 30 & Poland & 0.7 \\
\hline 31 & Iran & 0.62 \\
\hline 32 & Turkey & 0.61 \\
\hline 33 & Thailand & 0.6 \\
\hline 34 & Singapore & 0.59 \\
\hline 35 & Kuwait & 0.58 \\
\hline 36 & Ukraine & 0.57 \\
\hline 37 & Algeria & 0.53 \\
\hline 38 & Finland & 0.53 \\
\hline
\end{tabular}

\begin{tabular}{|c|c|c|}
\hline 39 & Ireland & 0.53 \\
\hline 40 & Iraq & 0.5 \\
\hline 41 & Libya & 0.48 \\
\hline 42 & Greece & 0.47 \\
\hline 43 & Israel & 0.45 \\
\hline 44 & Hungary & 0.44 \\
\hline 45 & Pakistan & 0.44 \\
\hline 46 & Portugal & 0.44 \\
\hline 47 & Romania & 0.44 \\
\hline 48 & Czech R. & 0.43 \\
\hline 48 & Philippines & 0.43 \\
\hline 50 & Egypt & 0.4 \\
\hline 51 & New Zealand & 0.38 \\
\hline 52 & Chile & 0.37 \\
\hline 53 & Colombia & 0.34 \\
\hline 54 & U.A.E. & 0.33 \\
\hline 55 & Bulgaria & 0.28 \\
\hline 56 & Peru & 0.28 \\
\hline 57 & Morocco & 0.26 \\
\hline 58 & Bangladesh & 0.24 \\
\hline 59 & Congo & 0.24 \\
\hline 60 & Zambia & 0.22 \\
\hline 61 & Serbia & 0.21 \\
\hline 62 & Vietnam & 0.21 \\
\hline 63 & Luxembourg & 0.2 \\
\hline 64 & Slovak Republic & 0.2 \\
\hline 65 & Sri Lanka & 0.19 \\
\hline 66 & Belarus & 0.18 \\
\hline 67 & Ghana & 0.18 \\
\hline 68 & Croatia & 0.17 \\
\hline 69 & Ecuador & 0.17 \\
\hline 70 & Kazakhstan & 0.17 \\
\hline 71 & Zimbabwe & 0.17 \\
\hline 72 & Côte d'Ivoire & 0.16 \\
\hline 73 & Trinidad \& Tob. & 0.16 \\
\hline 74 & Qatar & 0.15 \\
\hline 75 & Syria & 0.15 \\
\hline 76 & Uruguay & 0.15 \\
\hline
\end{tabular}




\begin{tabular}{|c|c|c|}
\hline 77 & Angola & 0.14 \\
\hline 78 & Jamaica & 0.14 \\
\hline 79 & Kenya & 0.14 \\
\hline 80 & Slovenia & 0.14 \\
\hline 8 & Tunisia & 0.14 \\
\hline 82 & Uzbekistan & 0.14 \\
\hline 83 & Lebanon & 0.13 \\
\hline 84 & Myanmar & 0.13 \\
\hline 85 & Yemen & 0.13 \\
\hline 86 & Dominican Rep. & 0.12 \\
\hline 87 & Oman & 0.12 \\
\hline 88 & Brunei & 0.11 \\
\hline 89 & Guatemala & 0.11 \\
\hline 90 & Panama & 0.11 \\
\hline 91 & Tanzania & 0.11 \\
\hline 92 & Bolivia & 0.1 \\
\hline 93 & Bosnia & 0.1 \\
\hline$\overline{94}$ & Cameroon & 0.1 \\
\hline$\overline{95}$ & El Salvador & 0.1 \\
\hline$\overline{96}$ & Jordan & 0.1 \\
\hline 97 & Lithuania & 0.1 \\
\hline 98 & Sudan & 0.1 \\
\hline 99 & Uganda & 0.1 \\
\hline 100 & Afghanistan & 0.09 \\
\hline 101 & Azerbaijan & 0.09 \\
\hline 102 & Costa Rica & 0.09 \\
\hline 103 & Cyprus & 0.09 \\
\hline 104 & Gabon & 0.09 \\
\hline 105 & Georgia & 0.09 \\
\hline 106 & Latvia & 0.09 \\
\hline 107 & Senegal & 0.09 \\
\hline 108 & Bahamas, & 0.08 \\
\hline 109 & Bahrain & 0.08 \\
\hline 110 & Ethiopia & 0.08 \\
\hline 111 & Honduras & 0.08 \\
\hline 112 & Iceland & 0.08 \\
\hline 113 & Liberia & 0.08 \\
\hline 114 & Madagascar & 0.08 \\
\hline 115 & Moldova & 0.08 \\
\hline
\end{tabular}

\begin{tabular}{|c|c|c|}
\hline 116 & Namibia & 0.08 \\
\hline 117 & Nicaragua & 0.08 \\
\hline 118 & Papua New Gui. & 0.08 \\
\hline 119 & South Sudan & 0.08 \\
\hline 120 & Armenia & 0.07 \\
\hline 121 & Estonia & 0.07 \\
\hline 122 & Guinea & 0.07 \\
\hline 123 & Guyana & 0.07 \\
\hline 124 & Mali & 0.07 \\
\hline 125 & Malta & 0.07 \\
\hline 126 & Mauritius & 0.07 \\
\hline 127 & Mozambique & 0.07 \\
\hline 128 & Paraguay & 0.07 \\
\hline 129 & Sierra Leone & 0.07 \\
\hline 130 & Suriname & 0.07 \\
\hline 131 & Barbados & 0.06 \\
\hline 132 & Botswana & 0.06 \\
\hline 133 & Burundi & 0.06 \\
\hline 134 & Cambodia & 0.06 \\
\hline 135 & Chad & 0.06 \\
\hline 136 & Congo & 0.06 \\
\hline 137 & Fiji & 0.06 \\
\hline 138 & Haiti & 0.06 \\
\hline 139 & Kyrgyz Republic & 0.06 \\
\hline 140 & Macedonia & 0.06 \\
\hline 141 & Malawi & 0.06 \\
\hline 142 & Nepal & 0.06 \\
\hline 143 & Niger & 0.06 \\
\hline 144 & Rwanda & 0.06 \\
\hline 145 & Tajikistan & 0.06 \\
\hline 146 & Togo & 0.06 \\
\hline 147 & Turkmenistan & 0.06 \\
\hline 148 & Albania & 0.05 \\
\hline 149 & Benin & 0.05 \\
\hline 150 & Burkina Faso & 0.05 \\
\hline 151 & Central African R. & 0.05 \\
\hline 152 & Equatorial Guinea & 0.05 \\
\hline 153 & Kosovo & 0.05 \\
\hline 154 & Lao & 0.05 \\
\hline
\end{tabular}




\begin{tabular}{|c|c|c|}
\hline 155 & Mauritania & 0.05 \\
\hline 156 & Mongolia & 0.05 \\
\hline 157 & Somalia & 0.05 \\
\hline 158 & Swaziland & 0.05 \\
\hline 159 & Belize & 0.04 \\
\hline 160 & Djibouti & 0.04 \\
\hline 161 & Eritrea & 0.04 \\
\hline 162 & Gambia, The & 0.04 \\
\hline 163 & Lesotho & 0.04 \\
\hline 164 & Montenegro & 0.04 \\
\hline 165 & San Marino & 0.04 \\
\hline 166 & St. Lucia & 0.04 \\
\hline 167 & Vanuatu & 0.04 \\
\hline 168 & Antigua and Bar. & 0.03 \\
\hline 169 & Bhutan & 0.03 \\
\hline 170 & Cape Verde & 0.03 \\
\hline 171 & Comoros & 0.03 \\
\hline
\end{tabular}

\begin{tabular}{|c|c|c|}
\hline 172 & Dominica & 0.03 \\
\hline 173 & Grenada & 0.03 \\
\hline 174 & Guinea-Bissau & 0.03 \\
\hline 175 & Kiribati & 0.03 \\
\hline 176 & Maldives & 0.03 \\
\hline 177 & Marshall Islands & 0.03 \\
\hline 178 & Micronesia & 0.03 \\
\hline 179 & Palau & 0.03 \\
\hline 180 & Samoa & 0.03 \\
\hline 181 & São Tomé and Príncipe & 0.03 \\
\hline 182 & Seychelles & 0.03 \\
\hline 183 & Solomon Islands & 0.03 \\
\hline 184 & St. Kitts \& N. & 0.03 \\
\hline 185 & St. Vincent \& G. & 0.03 \\
\hline 186 & Timor-Leste & 0.03 \\
\hline 187 & Tonga & 0.03 \\
\hline 188 & Tuvalu & 0.03 \\
\hline
\end{tabular}

This data shows a very sharp difference between members in their voting power as well. For example, the 100 IMF members having the smallest percentage of votes together have 155,645 votes or around $6.1 \%$ of the total votes (compared to $3.407 \%$ of the quotas) while the remaining 88 IMF members have 2,364,102 votes or around $93.9 \%$ of the total votes (compared to around $96.693 \%$ of the quota share). It is obvious that there is a difference between quota and votes $\%$ and that there is no exact proportion between the two. In the majority of cases, the quota share is slightly higher than the voting power of IMF members. This, although not too significant, is a positive discrimination in order to allow an increase of voting power for members with lower quotas and the decrease of voting powers for members with higher quota shares.

The country with the single largest quota and vote share, the United States, has 421,961 votes or $16.75 \%$ of the total votes (compared to the $17.69 \%$ of the quota). The US alone has votes in \% which equals almost 2.71 times the existing 100 smallest IMF voting power combined (compared to 5 times in the quota). The ratio is 1:271. Compared to the country with the smallest number of votes Tuvalu (755 votes) the ratio between the US and Tuvalu is 558:1. The 10 greatest voting powers have around 52.09 $\%$ of the total votes (compared to $54.8 \%$ of the quota) while remaining 178 IMF members have $47.91 \%$ of the total votes (compared to $55.2 \%$ of the share).

Moreover, if one reviews the voting power of the $27 \mathrm{EU}$ Members States compared to the remaining 161 IMF members, the difference is also very significant. The follow- 
ing table provides specific information on the number of votes of EU Member States in the IMF: ${ }^{898}$

${ }^{898}$ Based on estimates provided on the IMF web site at: http://www.imf.org/external/np/sec/memdir/members.aspx, (visited March 2013). 
Table 11: The number and \% of votes of EU member states in the IMF

\begin{tabular}{|c|c|c|}
\hline IMF MEMBER & NR.OF VOTES & $\%$ OF TOTAL \\
\hline Austria & 21,876 & 0.87 \\
\hline Belgium & 46,789 & 1.86 \\
\hline Bulgaria & 7,139 & 0.28 \\
\hline Cyprus & 2,319 & 0.09 \\
\hline Czech Republic & 10,759 & 0.43 \\
\hline Denmark & 19,651 & 0.78 \\
\hline Estonia & 1,676 & 0.07 \\
\hline Finland & 13,375 & 0.53 \\
\hline France & 108,122 & 4.29 \\
\hline Germany & 146,392 & 5.81 \\
\hline Greece & 11,755 & 0.47 \\
\hline Hungary & 11,121 & 0.44 \\
\hline Ireland & 13,313 & 0.53 \\
\hline Italy & 79,560 & 3.16 \\
\hline Latvia & 2,158 & 0.09 \\
\hline Lithuania & 2,576 & 0.1 \\
\hline Luxembourg & 4,924 & 0.2 \\
\hline Malta & 1,757 & 0.07 \\
\hline Netherlands & 52,361 & 2.08 \\
\hline Poland & 17,621 & 0.7 \\
\hline Portugal & 11,034 & 0.44 \\
\hline Romania & 11,039 & 0.44 \\
\hline Slovak Republic & 5,012 & 0.2 \\
\hline Slovenia & 3,487 & 0.14 \\
\hline Spain & 40,971 & 1.63 \\
\hline Sweden & 24,692 & 0.98 \\
\hline United Kingdom & 108,122 & 4.29 \\
\hline Total EU Members & 779,601 & $30.97 \%$ \\
\hline
\end{tabular}

The 27 EU Members States have 30.97\% of the total voting power compared to the 161 IMF members having around $69.03 \%$ of the total voting power.

In a stark difference to Europe, Africa is significantly under-represented. As stated by Watkins and Woods:

"Africa accounts for a quarter of the membership and just over 4 percent of the vote. Belgium (population 10 million) has more votes than Nigeria, Ethiopia, 
Zambia, Tanzania, Mozambique and South Africa combined (total population around 300 million). If it came to a vote, Africa might as well stay at home." ${ }^{899}$

To sum up, it is important to emphasize that the IMF does not grant equal voting power to its members in its decision-making. This institution uses a model of weighted voting, which implies inequality of the members in the decision-making process. Such a position influences all decision-making aspects including representation, voting power and the decision-making process used.

\section{MAJORITY AND CONSENSUS DECISION-MAKING IN THE IMF}

The second underlying principle relates to the majority and consensus decision-making processes in the IMF. Having introduced a system of weighted voting, the IMF is in deviation from the principle of equality of states in each of the decision-making process used. However, the deviation from the principle of equality of states is greater in majority decision-making due to the fact that the IMF members cast votes that are unequal and weighted. In the practice of using consensus decision-making (although the law of the IMF foresees majority decision-making) there is compliance and at the same time no compliance with the principle of equality of states. There is compliance due to the fact that no IMF member opposes a decision adopted by consensus and non compliance due to the fact that if no agreement is reached, the IMF members can always resort to majority decision-making which places members on unequal footing in the decisionmaking process.

\subsection{MAJORITY DECISION-MAKING IN THE IMF}

With regard to majority decision-making, in line with the other IGOs of the time, the IMF moved away from unanimity and introduced different types of majority decisionmaking as its main voting mechanism: simple majority, qualified majority, high majority and double majority. ${ }^{900}$ The majority of the decisions in the IMF are taken by simple majority of the votes cast. ${ }^{901}$ Certain issues related to the so called "important decisions" are adopted by a qualified majority (70\% majority) ${ }^{902}$ High majority (85\%) is required for decisions related to the structural issues. The structural issues are related to changes in quota subscription, adjustment of the SDRs allocations, the disposition of Gold

\footnotetext{
${ }^{899}$ Kevin Watkins and Ngaire Woods, “Africa must be heard in the councils of the rich”, International Herald Tribune, October 1, 2004, available at: http://www.iht.com/bin/print.php?file=541501.html, (visited May 2013).

${ }^{900}$ See Athena Debbie Efraim, Sovereign (In)equality in International Organizations, Martinus Nijhoff, 2000, pg. 204.

${ }_{901}$ Articles of Agreement of the IMF, Article XII Section 5 (c) states: "Except as otherwise specifically provided, all decisions of the Fund shall be made by a majority of the votes cast".

${ }_{902}$ See Articles of Agreement of the IMF, Article III, Section 3, (d); Article V, Section 7, (e), (g), Section 8 (d), Section 9 (a), (c); Article V, Section 12 (f), (h), (j); Article XII, Section 6, (d), (f); Article XII, Section 8; Article XV, Section 2 .
} 
supplies and the exceptional power to suspend provisions of the IMF Article of Agreement. ${ }^{903}$ A double majority is required for example for constitutional amendments: 3/5 of the member states and $85 \%$ of the total voting power. ${ }^{904}$ Naturally, the higher the majority required, the greater is also the legitimacy of the decision adopted.

Regardless of the type of majority decision-making used, they represent a deviation from the principle of equality of states. Although, at times there may be arguments to the contrary, and consider equality to be the reason for using weighted voting. This is based on the proposition that it would be unfair not to use weighted voting when members differ so much in the interests they represent. ${ }^{905}$

The deviation from the principle of equality of states is not due to the fact that the IMF uses majority decision-making; it is due to the fact that the IMF uses a weighted voting system resulting in inequality of voting powers between IMF Members. It has to be stated that although the Articles of Agreement do not foresee a formal veto power in the voting procedures, the high majority (85\%) provides a de facto veto power. ${ }^{906}$ This implies that USA in the IMF has de facto right to veto (USA has $16.75 \%$ of the votes or 421,961 votes ${ }^{907}$ of the IMF). Having in mind that the other member and group of members have less percentage of votes, it would require coalition of members or group of members to veto the decision that requires high majority. The United States, due to its voting power has de facto veto power in some key management decisions, admission of members, increase of quotas, allocations of Special Drawing Rights (SDRs), as well as amendments of the Articles of Agreement. ${ }^{908}$ Thus, the $85 \%$ majority that is required for an amendment of the Articles is both a safe guard of the status quo and a hindrance to any change for reform which would not be in line with the national interests of the USA. Except for the United States, also the EU Member States can block a great number of decisions if they vote as a group (in $70 \%$ majority decisions).

\footnotetext{
${ }^{903}$ See Articles of Agreement of the IMF, Article III, Section 2(c), Article IV, Section 2 (c), Section 4, ,Article V, Section 7 (c), (d), Section 12(b), Article V, Section 12 (f),(g), Article XII, Section 1, Section 3, (b), Article XXIX.

${ }^{904}$ Articles of Agreement of the IMF, Article XXVIII states: "when three-fifths of the members, having eighty-five percent of the total voting power, have accepted the proposed amendment, the Fund shall certify the fact by a formal communication addressed to all members."

${ }^{905}$ See Henry G. Schermers \& Niels M. Blokker, International Institutional Law, Fifth Revised Edition, Martinus Nijhoff Publishers, 2011, pg. 551.

${ }^{906}$ Athena Debbie Efraim, Sovereign (In)equality in International Organizations, Martinus Nijhoff, 2000, pg. 205; see also Andreas F. Lowenfeld, The International Monetary System: A Look Back Over Seven Decades, 13 J. Int'l. Econ. L. 575 (2010), pg. 577.

${ }^{907}$ IMF Executive Directors and Voting Power http://www.imf.org/external/np/sec/memdir/eds.aspx, (visited March, 2013).

${ }^{908}$ Leo Van Houtven, Governance of the IMF: Decision-making, Institutional Oversight, Transparency, and Accountability, Pamphlet Series No. 53, International Monetary Fund, 2002, pg. 11-12.
} 


\subsection{CONSENSUS DECISION-MAKING IN THE IMF}

If majority decision-making is the primary de jure decision-making mode in the IMF, consensus is the primary de facto mode of decision-making of the IMF. ${ }^{909}$ The legal provision that foresees consensus decision-making in the IMF is the rule C-10. The rule C-10 states that "the Chairman shall ordinarily ascertain the sense of the meeting in lieu of a formal vote" ${ }^{910}$ Consensus decision-making places considerable power in the hands of the Chairman which in the IMF has always been a European. ${ }^{911}$ This provision was adopted in 1946, during the initial stages of IMF development, at times when the US and the UK had more than a comfortable majority to decide by majority voting. ${ }^{912}$ As a result, in practice, the actual voting is very rare at the IMF and decisions are reached by consensus. ${ }^{913}$ The practice of consensus decision-making in the IMF is the result of the heterogeneous membership and of the variety of interests represented by such membership.

Consensus decision-making seems to provide advantages for both the industrial and the developing countries as well. In this manner, for the developing countries, which have a minority voting position, the consensus decision-making approach may yield a voice that is larger than their share of votes and a possibility of having greater influence in policy decisions. In the other hand, for the industrial countries, consensus decision-making helps to preserve the system of weighted voting that distinguishes the IMF from other international organizations, by making such system more acceptable to debtor countries. As stated by Murilo Portugal, a former Executive Director of the IMF:

"weighted voting based on relative economic strength gives confidence to creditor countries to commit financial resources to the IMF, while consensus decision-making confers some protection to the interests of minority groups, making weighted voting acceptable to debtor countries, and may lead to better decisions that are easier to implement. Special voting majorities of 70 per cent for certain key decisions also help to protect sizeable minorities". 914

This approach prevents the voting problems and ensures IMF efficiency.

\footnotetext{
${ }^{909}$ It is interesting that except for the IMF, also the World Bank and the WTO use consensus decision-making. See Nigel D. White, 'Decision-making' in Jan Klabbers and Åsa Wallendahl, Editors, Research Handbook on the Law of International Organizations, Edward Elgar Publishing Limited, 2011, pg. 229.

${ }^{910}$ Rules and Regulations of the International Monetary Fund, Rule C, 10.

${ }^{911}$ Nigel D. White, 'Decision-making' in Jan Klabbers and Åsa Wallendahl, Editors, Research Handbook on the Law of International Organizations, Edward Elgar Publishing Limited, 2011, pg. 229.

${ }^{912}$ Leo Van Houtven, Governance of the IMF: Decision-making, Institutional Oversight, Transparency, and Accountability, Pamphlet Series No. 53, International Monetary Fund, pg. 23.

${ }^{913}$ Andreas F. Lowenfeld, International Economic Law, Second Edition, Oxford University Press, 2008, pg. 604.

${ }^{914}$ Murilo Portugal, 'Improving IMF Governance and Increasing the Influence of Developing Countries in IMF Decision-Making', in Ariel Buria, Editor., Reforming the Governance of the IMF and the World Bank, Anthem Press, 2005, pg. 75.
} 
The practice of consensus decision-making in the IMF is in line with the application of the principle of equality of states. Osieke notes that consensus decision-making in the IMF is without a doubt a response to the criticism to the weighted voting system which is "contrary to the generally accepted principle of sovereign equality of states". 915 However, it has to be noted that the principle of equality of states and consensus decision-making in the IMF are not fully applied due to the fact that the underlying decision-making process is the majority and not consensus decision-making. The IMF members that have more votes can insert more pressure to adopt a certain decision due to the fact that if no agreement is reached, the decision can be adopted by a majority vote without the approval of all members. This creates a situation of unequal formal voting powers between IMF members although the decision may be adopted by consensus. Regardless of the fact that in both majority and consensus decision-making of the IMF there is a deviation from the principle of equality of states, it has to be noted that the deviation is greater in majority decision-making compared to consensus decisionmaking. The practice of consensus decision-making in the IMF except that is more in line with the principle of equality of states, it also provides for more legitimacy of the decisions adopted as no member opposed the decision adopted.

\section{THE BOARD OF GOVERNORS}

The Board of Governors is the highest decision-making body of the International Monetary Fund. It resumes all the powers conferred form the Articles of Agreement except for the ones directly conferred to the Executive Board and the Managing Director. ${ }^{916}$ It is a plenary body composed of one Governor and one Alternate appointed from each member. At the moment the Board of Governors is composed of 188 Governors and 188 Alternates. It is custom that most of the Governors are Ministers of Finance or Head of the Central Bank of the member states and meet only annually to discuss important matters of the International Monetary Fund. While the Board of Governors has delegated most of its powers to the IMF's Executive Board, it retains the right to approve quota increases, special drawing right (SDR) allocations, the admittance of new members, compulsory withdrawal of members, and amendments to the Articles of Agreement and By-Laws. The Board of Governors also elects or appoints executive directors and is the ultimate arbiter on issues related to the interpretation of the IMF's Articles of Agreement. ${ }^{917}$

The decision-making process in the Board of Governors is based on the voting powers of individual members represented by the Governor or the Alternate. This

\footnotetext{
${ }^{915}$ Ebere Osieke, Majority Voting Systems in the International Labour Organisation and the International Monetary Fund, 33 Int'l. Comp. L. Quart. 381 (1984), pg. 403.

${ }^{916}$ Articles of Agreement of the International Monetary Fund, Article XII, Section 2.

917 See Articles of Agreement of the IMF, Article XII, Section 2, Section 3 (c), Article XIX, Article XXI (a), Article XXV, Article XXVI Section 2.(c), Article XXVII Section 1(b), Section 2, Article XVIII (a), Schedule D 1(a) 3(a), Schedule E 1,2,3,4,5,7.
} 
implies that member of the IMF cast their votes according to their voting powers, from the US, as the owner of the largest number of votes, to Tuvalu as the smallest.

Meetings of the Board of Governors are convened when are requested by fifteen members or by members that have $25 \%$ of the total vote. ${ }^{918}$ This implies that the USA together with Japan and Germany has enough voting power to call a meeting of the Board of Governors. Nevertheless, the Boards of Governors of the IMF and the World Bank Group normally meet once a year, during the IMF-World Bank Spring and Annual Meetings, to discuss the work of their respective institutions.

The Article of the Agreement of the IMF stipulates that the quorum is reached when the members of Board of Governors present at the meeting have 2/3 of the voting power. ${ }^{919}$ This would imply that from the total of 2,515,719 votes, a group of IMF Members having 1677146 votes can acquire a quorum and they do not necessarily have to be a 2/3 majority of members but a minority of the largest percentage of votes. Voting in the Board of Governors usually takes place by mail-in ballot. The Board of Governors is functioning on the basis of weighted voting which implies asymmetry of power of the members of the Board of Governors. Even though each member state is represented in the annual meeting of the IMF, principle of weighted voting creates avenues for deviation from the principle of equality of states. Moreover, having in mind that the Board of Governors discusses the policy proposals from the Executive Board and that there is a practice that proposals from the Executive Board are accepted, it seems that the deviation from the principle of equality which is more vivid in the Executive Board is also present in the Board of Governors. As a plenary body, the Board of Governors confirms the agenda set by the Executive Board.

With regard to the application of the principle of the equality of states, it is evident that the Board of Governors in comparison with the Executive Board does not deviate from the principle of equality of states when it comes to representation only. In this aspect, all members are equally entitled to one Governor and one Alternate as all 188 members are represented in the Board of Governors. However, having non equal voting power makes equal representation less significant. As stated above, all IMF members have different voting powers which results in inequality between members in the decision-making process. Further on, for a number of issues such as determination of quorum, initiating a meeting and adopting decision, some members have a better decision-making position. As stated above, the smallest 100 IMF members have less than $10 \%$ of the total votes and they cannot bloc any decision regardless of the majority required except the one requiring a double majority ( $2 / 3$ of members).

${ }^{918}$ Articles of Agreement of the IMF, Article XII Section 2(c).

${ }^{919}$ Articles of Agreement of the IMF, Article XII Section 2(d). 


\section{THE EXECUTIVE BOARD}

The Executive Board is the non plenary body of the IMF and in practice the most important body. In practice, the Board of Governors delegates to the Executive Board all powers that are not expressly made non-delegable. ${ }^{920}$ It is a non plenary organ as not all members are equally represented. Moreover, the Executive Board applies a weighted voting system. In these two fundamental principles the Executive Board is in deviation from the principle of equality of states.

The Executive Board's limited membership has always represented a contentious issue. This has been the case from the establishment of the IMF. At its first inaugural meeting in 1946 the Executive Board was composed of twelve members, out of which, five represented the IMF members having the largest quotas (United States, UK, China, France and India) while the remaining seven were elected by the respective constituencies. ${ }^{921}$ The number of the Executive Directors has increased with the increase of the member countries in the International Monetary Fund. This is quite natural, as the IMF's Executive Board of 1947 with 44 IMF members cannot remain the same as the IMF's Executive Board of 2013 with 188 IMF Members. As a result, the Executive Board has doubled in size since the creation of the IMF. From 12 Executive Directors, the number increased to 20 by 1964 and 21 by 1978. Until 1978, according to the original Article of Agreements, two places in the Executive Board were reserved for Latin American states. ${ }^{922}$ In 1981, another increase to 22 Directors was done to allow the People's Republic of China to elect an Executive Director. Currently, the Executive Board is consisted of 24 Executive Directors with the Managing Director as chairman. ${ }^{923}$ The Executive Directors of the Executive Board are either appointed or elected by IMF members. ${ }^{924}$ Out of the existing Executive Directors, 5 are appointed by the: United States, Japan, Germany, France, and the United Kingdom; and the remaining 19 Directors are elected. There is a difference also within the 19 elected Executive Directors as 3 of them represent single countries as is the case with China, Saudi Arabia and the Russian Federation, while the remaining 16 Executive Directors represent groups of IMF countries. As a result of this division, 8 Executive Directors represent single countries, while 16 Directors represent not a country but a group of countries, members of the IMF. Such unequal representation between countries is not in compliance with the principle of equality of states. Another difference is that the appointed Executive Directors can at all times be replaced by another member while the elected Executive Directors cannot be replaced by their electoral constituency before the end of their

\footnotetext{
${ }^{920}$ Andreas F. Lowenfeld, International Economic Law, Second Edition, Oxford University Press, 2008, pg. 602.

${ }^{921}$ Leo Van Houtven, Governance of the IMF: Decision-making, Institutional Oversight, Transparency, and Accountability, Pamphlet Series No. 53, International Monetary Fund, 2002, pg. 20.

${ }_{922}$ Andreas F. Lowenfeld, International Economic Law, Second Edition, Oxford University Press, 2008, pg. 600.

${ }_{923} \mathrm{IMF}$ official web portal http://www.imf.org/external/np/sec/memdir/eds.aspx, (visited March, 2013).

${ }^{924}$ Joseph Gold, Interpretation: The IMF and International Law, Kluwer Law International, 1996, pg. xxvi.
} 
term. $^{925}$ These circumstances also create inequality between members as the appointing members have a direct influence in the appointed Executive Director and can replace him/her at anytime, while the members that are part of electoral constituencies potentially have significantly less influence in the elected Executive Directors as they cannot replace them at anytime.

The following table presents the existing 24 Directors of the IMF. ${ }^{926}$

Table 12: The 24 executive directors of the executive board and their voting powers

\begin{tabular}{|c|c|c|}
\hline & Executive Directors & Quota power \\
\hline 1 & $\begin{array}{l}\text { United States } \\
\text { (Appointed) }\end{array}$ & $16.75 \%$ \\
\hline 2 & $\begin{array}{l}\text { Japan } \\
\text { (Appointed) }\end{array}$ & $6.23 \%$ \\
\hline 3 & $\begin{array}{l}\text { Germany } \\
\text { (Appointed) }\end{array}$ & $5.81 \%$ \\
\hline 4 & $\begin{array}{l}\text { France } \\
\text { (Appointed) }\end{array}$ & $4.29 \%$ \\
\hline 5 & $\begin{array}{l}\text { United Kingdom } \\
\text { (Appointed) }\end{array}$ & $4.29 \%$ \\
\hline 6 & $\begin{array}{l}\text { Elected Director } \\
\text { Casting votes of: Armenia, Belgium, BiH, Bulgaria, Croatia, Cyprus, Georgia, Israel, } \\
\text { Luxembourg, Macedonia, Moldova, Montenegro, Netherlands, Romania, Ukraine. }\end{array}$ & $6.57 \%$ \\
\hline 7 & $\begin{array}{l}\text { Elected Director } \\
\text { Casting votes of: Columbia, Costa Rica, El Salvador, Guatemala, Honduras, Mexico, } \\
\text { Spain, Venezuela }\end{array}$ & $4.90 \%$ \\
\hline 8 & $\begin{array}{l}\text { Elected Director } \\
\text { Casting votes of: Albania, Greece, Italy, Malta, Portugal, San Marino }\end{array}$ & $4.22 \%$ \\
\hline 9 & $\begin{array}{l}\text { Elected Director } \\
\text { Casting votes of: Brunei, Cambodia, Fiji, Indonesia, Lao, Malaysia, Myanmar, Nepal, } \\
\text { Philippines, Singapore, Thailand, Tonga, Vietnam. }\end{array}$ & $3.93 \%$ \\
\hline 10 & Single cons. Elected- China & $3.81 \%$ \\
\hline 11 & $\begin{array}{l}\text { Elected Director } \\
\text { Casting votes of: Australia, Kiribati, Marshall Islands, Micronesia, Mongolia, New } \\
\text { Zealand, Palau, Papua New Guinea, Samoa, Seychelles, Solomon Islands, Tuvalu, } \\
\text { Uzbekistan, Vanuatu }\end{array}$ & $3.62 \%$ \\
\hline 12 & $\begin{array}{l}\text { Elected Director } \\
\text { Casting votes of: Antigua, Bahamas, Barbados, Belize, Canada, Dominica, Grenada, } \\
\text { Ireland, Jamaica, St. Kitts and Nevis, St. Lucia, St. Vincent and the Grenadines }\end{array}$ & $3.60 \%$ \\
\hline 13 & $\begin{array}{l}\text { Elected Director } \\
\text { Casting votes of: Denmark, Estonia, Finland, Iceland, Latvia, Lithuania, Norway, } \\
\text { Sweden }\end{array}$ & $3.40 \%$ \\
\hline
\end{tabular}

${ }^{925}$ Ibid., pg. xxviii.

${ }^{926}$ Note that the data provided will change as members pay their quota increases as a result of entry into effect of the 2008 Amendment on March 3, 2011. The data provided is last updated March 2013, See IMF web site at: http://www.imf.org/external/np/sec/memdir/eds.aspx, (visited March 2013). 


\begin{tabular}{|c|c|c|}
\hline & Executive Directors & Quota power \\
\hline 14 & $\begin{array}{l}\text { Elected Director } \\
\text { Casting votes of: Angola, Botswana, Burundi, Eritrea, Ethiopia, Gambia, Kenya, } \\
\text { Lesotho, Liberia, Malawi, Mozambique, Namibia, Nigeria, Sierra Leone, South Africa, } \\
\text { South Sudan, Sudan, Swaziland, Tanzania, Uganda, Zambia, Zimbabwe }\end{array}$ & $3.29 \%$ \\
\hline 15 & $\begin{array}{l}\text { Elected Director } \\
\text { Casting votes of: Bahrain, Egypt, Iraq, Jordan, Kuwait, Lebanon, Libya, Maldives, } \\
\text { Oman, Qatar, Syria, UAE, Yemen }\end{array}$ & $3.18 \%$ \\
\hline 16 & $\begin{array}{l}\text { Elected Director } \\
\text { Casting votes of: Austria, Belarus, Czech Republic, Hungary, Kosovo, Slovak Republic, } \\
\text { Slovenia, Turkey }\end{array}$ & $2.92 \%$ \\
\hline 17 & $\begin{array}{l}\text { Elected Director } \\
\text { Casting votes of: Bangladesh, Bhutan, India, Sri Lanka }\end{array}$ & $2.81 \%$ \\
\hline 18 & Saudi Arabia & $2.80 \%$ \\
\hline 19 & $\begin{array}{l}\text { Elected Director } \\
\text { Casting votes of: Azerbaijan, Kazakhstan, Kyrgyz Republic, Poland, Serbia, Switzer- } \\
\text { land, Tajikistan, Turkmenistan }\end{array}$ & $2.77 \%$ \\
\hline 20 & $\begin{array}{l}\text { Elected Director } \\
\text { Casting votes of: Brazil, Cape Verde, Dominican Republic, Ecuador, Guyana, Haiti, } \\
\text { Nicaragua, Panama, Suriname, Timor-Leste, Trinidad and Tobago }\end{array}$ & $2.61 \%$ \\
\hline 21 & Russian Federation & $2.39 \%$ \\
\hline 22 & $\begin{array}{l}\text { Elected Director } \\
\text { Casting votes of: Afghanistan, Algeria, Ghana, Iran, Morocco, Pakistan, Tunisia }\end{array}$ & $2.26 \%$ \\
\hline 23 & $\begin{array}{l}\text { Elected Director } \\
\text { Casting votes of: Argentina, Bolivia, Chile, Paraguay, Peru, Uruguay, }\end{array}$ & $1.84 \%$ \\
\hline 24 & $\begin{array}{l}\text { Elected Director } \\
\text { Casting votes of: Benin, Burkina Faso, Cameroon, Central African Republic, Chad, } \\
\text { Comoros, Congo Democratic Republic, Congo Republic of, Cote d'Ivoire, Djibouti, } \\
\text { Equatorial Guinea, Gabon, Guinea, Mali, Mauritania, Mauritius, Niger, Rwanda, Sao } \\
\text { Tome and Principe, Senegal, Togo }\end{array}$ & $1.55 \%$ \\
\hline
\end{tabular}

The table illustrates the inequality in voting powers between members of the Executive Board. This inequality is reflected between all Executive Directors. Neither of the appointed Executive Directors have the same voting powers among themselves, or the elected ones regardless if they represent a single member or a group of members. It is interesting that the Board of Governors adopts a regulation for each biennial election which includes a regulation on the proportion of votes needed for the election of the Executive Directors with the goal to approximate the equality of voting powers between the elected Directors. ${ }^{927}$ However, the result does not seem to best comply with the foreseen goal for approximate equality between the votes of the elected Directors as they range from $1.55 \%$ of votes to $6.57 \%$ of votes per elected Executive Director.

Moreover, the situation with the voting power of the appointed Executive Directors brings into the light the fact that five countries (USA, Japan, Germany, France and

${ }^{927}$ Joseph Gold, Interpretation: The IMF and International Law, Kluwer Law International, 1996, pg. xxvi. 
United Kingdom) have around 37.37\% of the voting power of the Executive Board and thus consequently the prime powers in the affairs of International Monetary Fund. The remaining 183 members have around $62.63 \%$ of the voting power.

It is evident that there is a deviation from the principle of equality of states in the most important operational body of the IMF, the Executive Board. Even though there are 188 members of the IMF there are only 24 Executive Directors. This model of the weighted power discriminates smaller countries that have to be part of multiconstituency in order to protect their interest. In addition, there is evident distinction in the powers between the Executive Directors. The appointed Directors of the Executive Board act and vote on behalf of the appointed IMF members.

The numerical advantage of the industrialized countries representation on the Executive Board is significant even though the Board tends to operate by consensus. The reason is that these countries, because of their permanent presence on the Board, are able to develop institutional memories and expertise in how to function in the IMF. As a conclusion, the asymmetry of power in the Executive Board is in collision with the principle of equality of states. Directors may require formal voting but in practice the procedure is flexible and formal voting is extremely rare. This is the case due to the fact that power relations (deliberation of the executive directors of certain states) provide clear picture about an issue which averts directors to insist on formal record voting. ${ }^{928}$

To sum up, there is a deviation from the principle of equality of states in the Executive Board with regard to representation and voting powers. A number of Executive Directors are appointed while others are elected. A number of Executive Directors represent single constituencies while others represent multiple constituencies. In such a situation there is obvious inequality between members and as a result there is a deviation of the principle of equality of states. Moreover, the decision-making process which relies on a combination of majority decision-making based on a weighted voting power of members represents a clear deviation from the principle of equality of states.

\section{THE MANAGING DIRECTOR AND THE STAFF}

While the UN has a Secretary General and a Secretariat, the WTO its Director General and a Secretariat, the IMF has a Managing Director and a staff. In the discharge of their functions, the Managing Director and the staff should respect the international character of the duty and refrain from any attempts to influence any of the staff..$^{929}$ Overall it is considered that this mandate has been fulfilled, as in many instances the non political nature of the IMF has stood its ground even by making unpopular recommendations to member countries. ${ }^{930}$

${ }^{928}$ Ervin P. Hexner, The Executive Board of the International Monetary Fund: A Decision-Making Instrument, 18 Int'l. Org. 74 (1964), pg. 91.

${ }_{929}$ Articles of Agreement of the IMF, Article XII, Section 5, (c).

${ }^{930}$ Andreas F. Lowenfeld, International Economic Law, Second Edition, Oxford University Press, 2008, pg. 601. 


\subsection{THE MANAGING DIRECTOR}

There's been a gentleman's agreement between the United States and the European countries that the IMF Managing Director will be European and that the President of the World Bank will be a US national. ${ }^{931}$ As a return, the US has practical veto power to block a number of decisions in the IMF. ${ }^{932}$

The Managing Director is the Chairman of the Executive Board and the chief operating officer of the Fund, conducting the ordinary business of the Fund under the direction of the Executive Board. Although the Managing Director does not have the right to vote in the Executive Board, (except in the event of tie), the 70 year practice shows that the Managing Director has sufficient influence in the decision-making process of the IMF. ${ }^{933}$

The Managing Director and the staff exercise their functions under the effective direction of the Executive Board. Under the organizational hierarchy Executive Board appoints and relieves from his/her functions the Managing Director at any time. The most contentious issues in the application of the principle of equality of states with regard to representation of IMF Managing Directors is their nationality. Chronologically, the following IMF Managing Directors have been elected since 1946: Camille Gutt (Belgium, 1946-1951) Ivar Rooth, (Sweden 1951-1956), Per Jacobsson (Sweden, 19561963), Pierre-Paul Schweitzer (France, 1963-1973), Johannes Witteveen (Netherlands, 1973-1978), Jacques de Larosière (France, 1978-1987), Michel Camdessus (France, 1987-2000), Mr. Horst Köhler (Germany, 2000-2004), Rodrigo de Rato (Spain, 2004 2007), Mr. Dominique Strauss-Kahn (France, 2007-2011), Christine Lagarde (France, 2011-present). ${ }^{934}$

Representation by nationality of Managing Directors is better illustrated in the following chart: ${ }^{935}$

Chart 14: IMF Managing Directors by nationality

\footnotetext{
${ }^{931}$ Jacob Katz Cogan, Representation and Power in International Organization: The Operational Constitution and its Critics, 103 Am. J. Int'l. L. 209 (2009), pg. 209-210.

${ }_{932}$ Ronald A. Reis, The World Trade Organization (Global Organizations), Chelsea House Publishers, 2009, pg. 42.

${ }_{933}$ See for example the influences of Managing Directors such as Pierre-Paul Schweitzer (1963-73), the Managing Director Jacques de Larosière (1978-86), Michel Camdessus (1987-2000), at Leo Van Houtven, Governance of the IMF: Decision-making, Institutional Oversight, Transparency, and Accountability, Pamphlet Series No. 53, International Monetary Fund, 2002, pg. 13.

${ }_{934}$ See the List of IMF Managing Directors at the IMF web site at: http://www.imf.org/external/np/exr/chron/mds.asp, (visited March, 2013).

${ }_{935}$ Estimated based on data provided by MF web page at: http://www.imf.org/external/np/exr/chron/mds.asp, (visited March 2013).
} 


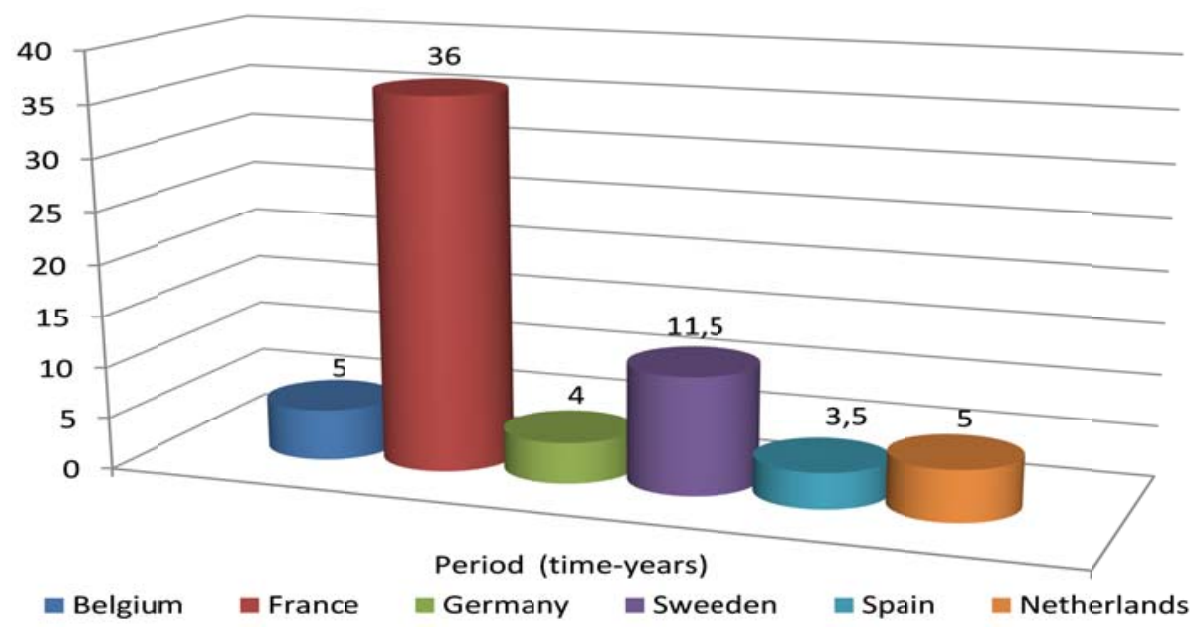

Around 65 year of experience confirms the existence of the unwritten agreement that the IMF Managing Director will always be a Western European. France is the country with the greatest representation (five IMF Managing Directors) having a French national serving for more than 36 years out of the total 65 years of existence of the IMF. The practice that implies informal methods for selecting a Western European as the head of the IMF has been criticized by academics, governments and non-governmental organizations who rightly argue that this approach is not in compliance with the principles of transparency, legitimacy and meritocracy as underlying principles of global governance. In these lines, the Ministers of Finance of Australia, Brazil and South Africa declared that the president of the World Bank "should be appointed using an open, transparent selection process with candidates not restricted by nationality". ${ }^{936}$

\subsection{THE STAFF}

There are around 2,400 people employed as IMF staff. ${ }^{937}$ As the membership of the IMF increased over time, also it has become important for the IMF that "all members can be at the table" and that this goal can be enhanced by having a staff that reflects broadly the membership. ${ }^{938}$ According to the official statistical data, the quota asymmetry is reflected in the staff of the IMF as well. The underrepresentation of developing members is visible in the staff structure as industrialized countries have better representation in the staff of the IMF. The IMF governance structures being aware of this fact issued a "statement on diversity". It states that an:

${ }^{936}$ See Peter S. Goodman, “Bush to Pick Zoellik for World Bank”, The Washington Post, May, 30, 2007, available at http://www.washingtonpost.com/wp-dyn/content/article/2007/05/29/AR2007052900760.html? hpid=topnews, (visited May 2013).

${ }_{937}$ See IMF web page at: http://www.imf.org/external/about/staff.htmInternational Monetary Fund, (visited March, 2013).

${ }^{938}$ See Diversity Annual Report, International Monetary Fund, 2011, pg. 4-5. 
"IMF staff that reflects the diversity of its membership will enhance legitimacy and understanding of the Fund's role, and strengthen the Fund's ability to serve its member countries... As an international organization, our work requires a staff that is diverse in nationality, academic, cultural, and professional background, and gender. Drawing effectively on diverse perspectives will add value to our decision-making, enrich the quality of our policy advice, and enhance our efficiency and effectiveness."

Moreover, the IMF has been building institutional capacity to improve the situation through diversification of the staff through policies and special institutional arrangements (Diversity Council, Diversity Office and Diversity Advisor) that would implement and monitor the diversification (region, origin and gender) process of the staff in every level of the hierarchical structure of the IMF. One of the outputs of these institutions is the annual diversity report. The Annual Diversity Report for 2011 provides detailed data of the staff working for the IMF based on various parameters, including inter alia nationality as well as belonging to industrialized or developing IMF members.

The most relevant parameters when it comes to the application of the principle of equality of states is the one of nationality of staff and the proportion between industrialized and developing members. ${ }^{940}$

Table 13: IMF staff nationality by region, country and total staff (excluding the office of executive directors) as of April 30, 2012.

\begin{tabular}{lll}
\hline Region & $\begin{array}{l}\text { Country } \\
\text { Quota \% }\end{array}$ & $\begin{array}{l}\text { Total Staff \% } \\
\text { (Economists \& Special Career Streams) }\end{array}$ \\
\hline Africa & 4.2 & 7.7 \\
Asia & 19.1 & 19.1 \\
Australia \& New Zealand & 1.9 & 1.8 \\
India & 1.9 & 4.6 \\
East Asia & 14.6 & 11.5 \\
Japan & 6.1 & 2.2 \\
Other Asia & 0.6 & 1.2 \\
Europe & 40.6 & 33.3 \\
U.K. & 5 & 5 \\
European Transition Countries & 7.4 & 7.3 \\
Other Europe & 28.9 & 21
\end{tabular}

\footnotetext{
${ }^{939}$ IMF Statement on Diversity, January 4, 2008. See IMF website at: http://www.imf.org/external/hrd/diversity.htm, (visited March 2013). Note however that efforts on diversity can at times also create resistance among staff being concerned that attention to diversity may lessen opportunities for advancement of staff and on the other hand it can also 'backlash' with underrepresented groups who may feel uncomfortable with the assumption that their progress has not to do with competence and professionalism but belonging to a certain group, see Diversity Annual Report, International Monetary Fund, 2011, pg. 3.

${ }_{940}$ Data based on estimates provided by the Diversity Annual Report, International Monetary Fund, 2011, pg. 34.
} 


$\begin{array}{lll}\text { Middle East } & 8.7 & 4.1 \\ \text { Saudi Arabia } & 3.2 & 0.1 \\ \text { Other Arab Countries } & 3.7 & 2.9 \\ \text { Other Middle East } & 1.8 & 1.1 \\ \text { U.S. \& Canada } & 20.1 & 22.9 \\ \text { U.S. } & 17.1 & 20.1 \\ \text { Canada } & 2.9 & 2.8 \\ \text { Western Hemisphere } & 7.3 & 12.9\end{array}$

If analyzed, the data also provides for the percentages of quota contribution and the total staff of developing and industrial countries which are presented in the following chart. Namely, the industrial countries provide for $60.2 \%$ of the quota and 51.4 of the total staff, while the developing countries provide for $39.8 \%$ of the quota share and $48.6 \%$ of the total staff. ${ }^{941}$

This division can be better illustrated in the following chart:

Chart 15: Staff representation and quota share difference between developing and industrial countries

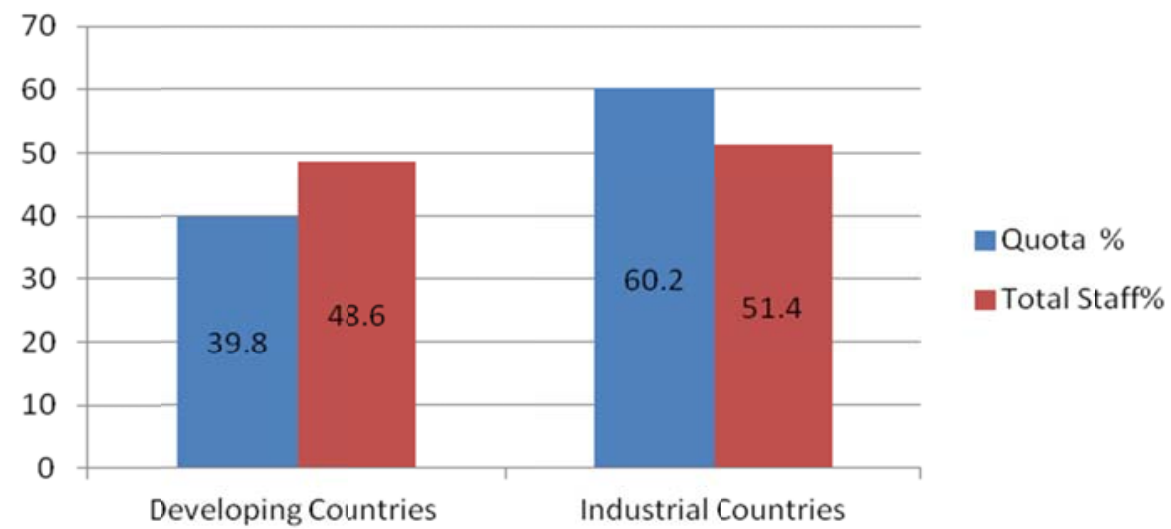

According to this report the representation by nationality of staff varies from one member to the other. At times there are alignments between the percentage of quotas by members and their representation of staff and at times there is over-representation or under-representation. However, to base the comparison of staff representation on the particular quotas of individual members entails the use of weighted voting in evaluating representation of staff and this in itself is a parameter not in compliance with the principle of equality of states. The positive aspect for the application of the principle of equality of states with regard to representation are the efforts undertaken by the IMF to have a more diverse staff representing a broad range of members.

${ }^{941}$ Ibid. 


\section{IMF REFORM AND THE PRINCIPLE OF EQUALITY OF STATES}

In the last years there have been strong voices for reforms that would enhance voice and representation and provide for a stronger influence in the decision-making processes for the emerging economies. For example during the 2006 Singapore Annual Meeting of the Fund, the Board of Governors adopted the Resolution on Quota and Voice Reform also called as the "Singapore Resolution". This resolution requested a reform program of the IMF in order to make a significant realigning of quota shares and enhance participation and voice of low income countries. ${ }^{942}$

These calls opened the way for the reforms in 2008 with an aim to adjust the quota from advanced to emerging and developing economies. The 2008 reforms were adopted on April 28 by an overwhelming majority of 180 out of 185 governors representing $92.93 \%$ of the total voting power of the Fund. ${ }^{943}$ The reforms of 2008 became effective by March 2011 with the ratification of the reforms by 117 Members representing $85 \%$ of the total voting power of the IMF. ${ }^{944}$ As a result, a major important shift was made by the increase of quotas for China, Korea, Mexico and Turkey and second, by tripling the basic votes of all IMF Members and thus enhance the voice and representation of Members. ${ }^{945}$

Chart 16: Changes in the quota shares

\footnotetext{
${ }^{942}$ See Reform of Quota and Voice in the International Monetary Fund- Report of the Executive Board to the Board of Governors, International Monetary Fund, March 28, 2008.

${ }^{943}$ See Press Release No. 08/93, April 29, 2008, IMF Board of Governors Adopts Quota and Voice Reforms by Large Margin. The large margin shows the overwhelming support for reforming the IMF in light of the new economic developments in the world.

${ }_{944}$ See Press Release No. 11/64, March 3, 2011, The IMF’s 2008 Quota and Voice Reforms Take Effect.

${ }_{945}$ IMF Quota and Governance Reform-Elements of an Agreement -IMF Finance Legal, Strategy, Policy and Review Departments, October 2010; See Press Release No. 08/64, March 28, 2008, IMF Executive Board Recommends Reforms to Overhaul Quota and Voice.
} 


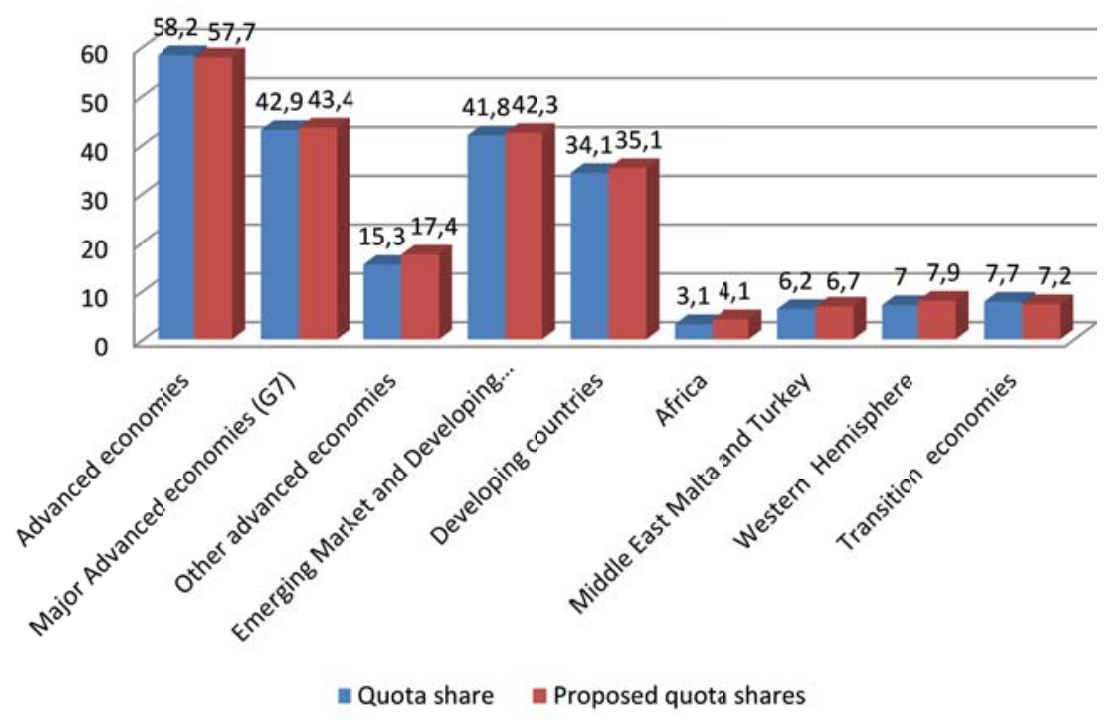

The graph illustrates increases of shares in the developing economies, Africa, Middle East Malta and Turkey, Western Hemisphere and decrease in the advanced economies and transition countries. After the 2008 Reforms, the approval of the last reforms in the IMF was made by the decision of the Executive Board to changes in the quota and governance of the IMF in 2010. According to the Managing Director at the time, the historic agreement represents the "most fundamental governance overhaul in the Fund's 65-year history and the biggest ever shift of influence in favor of emerging market and developing countries to recognize their growing role in the global economy”. ${ }^{946}$ The reforms of 2010 when entering into force (as of March 2013) will provide changes for the quota and voting shares as well as of the governance of IMF. With regard to the quotas and voting shares, the idea is that the overall quotas will double from SDR 238.4 billion to SDR 476.8 billion; there will be a quota shift of $6 \%$ from over-represented to under-represented members and more than $6 \%$ shift to developing countries and dynamic markets resulting with an increase of the total voting share of $5.3 \%$ together with the 2008 reform. ${ }^{947}$

This will result with 110 IMF Members having their quotas maintained or increased out of which 102 are emerging or developing countries and the 10 largest members or the IMF will reflect the largest economies of the world: United States, Japan, France Germany, Italy, UK, Brazil, China, India and Russia.

With regard to IMF Governance, the 2010 reform foresees that the number of 24 Executive Directors will be maintained in the Executive Board, although the European

\footnotetext{
${ }_{946}$ See Press Release No. 10/418, November 5, 2010, IMF Executive Board Approves Major Overhaul of Quotas and Governance.

${ }^{947}$ See IMF web site on Reforming of the IMF at: http://www.imf.org/external/np/sec/pr/2010/pr10418.htm, (visited March 2013).
} 
Countries will reduce their representation by two chairs, and that all Executive Director will be elected. ${ }^{948}$

These reforms are welcomed in the light of the application of the principle of equality of states as they aim more equal representation of IMF Members. They represent a step forward to decrease inequality by the increase of the basic votes, enhance of quota shares (which results in more enhanced representation of voting powers) as well as an all-elected Executive Board. However, these reforms are not and cannot address fully the inequality in representation and voting powers of members in the governing structures, especially in the Executive Board of the IMF as prima source of power in this institution. Therefore, it can also be argued that they are not in line with the principle of equality of states having in mind that no discussions of IMF reforms are conducted with the goal to ensure full equality of representation and voting power of all members. As a result even a reformed IMF will continue to be in deviation from the principle of equality of states. From this perspective, in fact, the IMF reform may continue to be in line with the existing weighted voting system and inequality of representation as they only reflect some of the economic (and power) changes that have occurred in the meantime. In these lines, Dunoff notes that:

"Significantly, at both the IMF and the Bank, the impetus for reform was not a sense that weighted voting was inconsistent with the legal equality of states. Rather, the debates centered around the need to reflect dramatic changes in the composition of the global economy, and to enhance the voice and participation of developing and transition countries in the IFIs to strengthen their long-term effectiveness and financial capacity. "949

\section{DECISION-MAKING AND THE PRINCIPLE OF EQUALITY OF STATES IN THE IMF}

The IMF decision-making has a number of ramifications to the (non) application of the principle of equality of states with regard to representation, the decision-making processes as well as the voting power of members.

With regard to representation, it should be noted that the principal powers of the IMF are vested in the Board of Governors, the plenary body of the IMF; although de facto the Executive Board is the most important body due to the fact that the Board of Governors delegates most of its decision powers to the Executive Board. The Board of Governors is the IMF plenary body composed of one Governor and one Alternate appointed from each member. With regard to representation, the Board of Governors is

\footnotetext{
${ }^{948}$ Also see IMF Quota and Governance Reform-Elements of an Agreement, Prepared by the Finance, Legal, and Strategy, Policy, and Review Departments, Approved by Andrew Tweedie, Sean Hagan, and Reza Moghadam, October 31, 2010. The Reform albeit foresees a major realignment of the quota shares and subsequently the voting share of member, it protects the share of 49 of the IMF's poorest members, see pg. 4.

949 Jeffrey L. Dunoff, Is Sovereign Equality Obsolete? Understanding Twenty-First Century International Organizations, 43 Neth. YBIL 99 (2013), pg. 120.
} 
in compliance with the principle of equality of states. However, with regard to voting power, the Board of Governors is in deviation from the principle of equality of states. On the other hand, the Executive Board with its limited membership and the inequality of voting powers between IMF members, represent a deviation from the principle of equality of states with regard to both representation and voting power. Even within the Executive Directors of the Executive Board there is no equality in terms of voting power and in most cases with regard to representation. A number of Executive Directors are appointed while others are elected. A number of Executive Directors represent single constituencies while others represent multiple constituencies. In such a situation there is inequality between members which results in a clear deviation from the principle of equality of states.

The fact that the IMF Managing Director is always a Western European obviously results in a deviation from the principle of equality of states due to the fact that the majority of IMF members have never had one of their nationals appointed as a Managing Director. With regard to the IMF staff, the underrepresentation of developing members is visible in the staff structure as industrialized countries have better representation in the staff of the IMF. With regard to voting power of IMF members, its weighted voting system represents a clear deviation from the principle of equality of states. All IMF members have a weighted voting power which is calculated based on the: 1) quota share; 2) basic votes; and the 3) voting power (which equals the total of the quota and the basic votes). Based on the quota share and the initial 250 basic votes, the voting power of every member is determined. Every member receives additional vote per 100000 SDR of its quota. Therefore, the greater the quota, the greater the financial responsibility of the members but most importantly, the greater the voting power. Such a weighted voting system results in inequality between members and a deviation from the principle of equality of states with regard to representation and the decision-making processes used.

Having introduced a system of weighted voting, the IMF is in deviation from the principle of equality of states in any of the decision-making processes used, consensus and/or majority decision-making. However, the deviation is greater in majority decision-making due to the fact that the IMF members cast votes that are unequal and weighted. In the practice of using consensus decision-making (although the law of the IMF foresees majority decision-making) there is compliance and at the same time no compliance with the principle of equality of states. There is compliance due to the fact that no IMF member opposes a decision adopted by consensus and non compliance due to the fact that if no agreement is reached, the IMF members can always resort to majority decision-making which places members on unequal footing in the decisionmaking process.

The IMF reforms have increased representation of members and as such can be observed to be in line with the principle of equality of states. However, at the same time they can also be observed to be in deviation from the principle of equality of states as 
they do not introduce equality of representation and voting power. As such, the IMF reforms only reflect the changes in the economies of a number of states within the existing weighted voting system of the organization.

\section{THE BUDGET}

The IMF (as is the case with the IBRD and IFC) does not receive contributions from its members for the IMF budget as it derives income from other sources (various charges on transactions and short-term investments). ${ }^{950}$ Contributions by members through quotas or shares are different as they are not used for the operation of the organization itself. $^{951}$

Having in mind that there are no contributions by individual members for the IMF's budget, a review of this section in light of the principle of equality of states is pointless. Note that the share of individual members in the form of quotas has been reviewed in the previous sections.

\section{SUSPENSION, EXPULSION AND WITHDRAWAL OF MEMBERS IN THE IMF}

The IMF Articles of Agreement foresee the possibility for suspension, expulsion and withdrawal from the IMF. It must be stated here that the Articles of Agreement of the IMF instead of a provision using the notion "expulsion" have opted for the use of a nice euphemism by referring to compulsory withdrawal (expulsion) from the IMF. ${ }^{952}$

With regard to suspension, if a member fails to fulfill any of its obligations foreseen by the Articles of Agreement, including the use of the Fund's general resources in a manner deemed contrary to the purposes of the organization, then, the IMF may limit the use of these resources or declare the member ineligible to use the general resources. ${ }^{953}$ If after the declaration of ineligibility the member persists in the failure to fulfil any of its obligations, the IMF may suspend the members voting rights by a majority of seventy percent of the voting power. ${ }^{954}$ By the same majority (seventy percent) the suspension may be terminated. There is a deviation from the principle of equality of states as the provisions may not apply equally to all IMF members due to the weighted majority required to decide on cases of suspension or termination of IMF members. For example, members that have greater voting powers are less likely to be

950 Philippe Sands and Pierre Klein, Bowett's Law of International Institutions, Sixth Edition, Sweet \& Maxwell, 2009, pg. 572.

${ }^{951}$ Ibid., pg. 573.

${ }^{952}$ Jan Klabbers, An Introduction to International Institutional Law, Second Edition, Cambridge University Press, 2009, pg. 109.

${ }^{953}$ See Articles of Agreement of the IMF, Article XXVI, Section 2, (a) and Article V, Section 5. Also see C. F. Amerasinghe, Principles of the Institutional Law of International Organizations, Second Edition, Cambridge University Press, 2005 Amerashinghe, pg. 116.

${ }^{954}$ See Articles of Agreement of the IMF, Article XXVI, Section 2, (b). During the period of the suspension, the provisions of Schedule L shall apply. 
suspended in proportion to the ones with smaller voting powers. Moreover, groups of members such as the five appointed members in the Executive Board having more than $30 \%$ of the vote or the EU as a group can actually block any decisions.

Further on, if suspension of a member does not result in compliance, and the member continues not to fulfill its obligations under the Articles of Agreement, then that member may be forced to withdraw, which in practical terms means that the member is expelled. Such a decision is made by the Board of Governors if a majority of eighty-five percent of the total voting power is in favor of such a decision. ${ }^{955}$ In this case there is also a deviation from the principle of equality of states due to the weighted voting decision-making which requires an eighty-five percent majority. The chances for being forced to withdraw obviously are proportionality aligned to the voting power of IMF members. The greater the voting power, the smaller the chances for forced expulsion. Moreover, one IMF member (the US having more than $15 \%$ of votes) can never be forced to withdraw. The IMF rules on forced withdrawal are a clear deviation from the principle of equality of states due to the decision-making process which is based on a weighted voting system where IMF members have different voting powers.

With regard to withdrawal, it should be noted that the IMF Articles of Agreement do contain a withdrawal clause in Article XXVI which foresees that any member, at any time, may withdraw from the IMF by sending a notice to the principle office of the Fund. ${ }^{956}$ The withdrawal takes effect on the date the notice is received. Such a provision as stated in the previous sections is in full compliance with the principle of equality of states.

\section{CONCLUSION}

The main feature of the IMF is the system of weighted voting which represents a deviation from the principle of equality of states. The establishment of the IMF and the entry into force of its founding treaty was based on unequal treatment of states due to the weighted system required. Namely, the IMF Articles of Agreement entered into force only when the number of signatories at the same time represented a percentage of the required quota. Such a requirement is a deviation from the principle of equality of states as it weighs between the signatures of equal states. In similar lines, also for the amendment of the IMF Articles of Agreement, a weighted voting system is established. In this manner, the high majority (85 percent of votes) required for the amendment of the IMF Articles of Agreement represents a formal protection of the existing status quo as the major shareholder of the IMF, having $16,76 \%$ of votes, can block any such decisions. This may also be the case if a number of members (such as EU Members in the IMF) vote as a group.

${ }^{955}$ See Articles of Agreement of the IMF, Article XXVI, Section 2, (c).

${ }^{956}$ Articles of Agreement of the IMF, Article XXVI, Section 1. 
The IMF Articles of Agreement do not have any direct references to the principle of equality of states. However, this does not mean that the principle of equality of states does not apply to the IMF. With the fact that the IMF is an international organization, as such, it is bound by international law and the principle of equality of states. Moreover, there authors (such as Efraim) that argue that the IMF is obligated to respect the principle of equality of states due to the fact that it is a Specialized Agency of the UN and as such it should respect all the principles (including the principle of equality of states) of the UN.

With regard to the application of the principle of equality of states in acquisition of membership, a number of issues are of importance. First, participation in the negotiations for the establishment of the IMF was rather limited. Before the Bretton Woods Conference, opportunity for consultations was provided to France and Canada in particular, and to a limited number of states in the Atlantic City Conference. Participation at the Bretton Woods Conference was limited only to the states receiving invitation from the US. All the participating states were either part of the United Nations, the Associated Powers or the countries in close relations to them. No invitations were extended to the Axis powers. The countries participating in the Bretton Woods conference had an opportunity to be part of the decision-making for the establishment of the IMF and to acquire original membership. Such an option was not possible for any other country not being invited to the Bretton Woods Conference. This was not in coherence with the principle of equality of states. The establishment of a universal international organization should be an opportunity for all interested states to participate equally in the negotiations and the decision-making process. The fact that this was done during World War II was very unfortunate and did not make it plausible for all states to participate.

Second, with regard to admission, it is important to state that the weighed voting system used as a basis to assign quota shares for the new members, represents an underlying deviation from the principle of equality of states. Decisions on admission are adopted by the plenary body of the IMF, or the Board of Governors. However, the majority decision-making process required in the Board of Governors concerning the admission of new members is a deviation from the principle of equality of states due to the weighed voting system.

With regard to decision-making, it is important to emphasize that the IMF does not grant equal voting power to its members in its decision-making. This institution uses a model of weighted voting, which implies inequality of the members in the decisionmaking process. Such a position influences all decision-making aspects including representation, voting power and the decision-making process used. The practice of consensus decision-making in the IMF is in line with the application of the principle of equality of states. However, it has to be noted that the principle of equality of states in consensus decision-making in the IMF are not fully applied due to the fact that the underlying decision-making process is the majority and not consensus decision-making. The IMF members that have more votes can insert more pressure to adopt a certain 
decision due to the fact that if no agreement is reached, the decision can be adopted by a majority vote without the approval of all members.

With regard to representation of members in the IMF, it is evident that the Board of Governors in comparison to the Executive Board does not deviate from the principle of equality of states when it comes to representation. In this aspect, all members are equally entitled to one Governor and one Alternate as all 188 members are represented in the Board of Governors. However, having non equal voting power makes equal representation less significant. The Executive Board's limited membership has always represented a contentious issue. The Executive Directors are either appointed or elected by IMF members. Out of the existing Executive Directors, 5 are appointed by the: United States, Japan, Germany, France, and the United Kingdom; and the remaining 19 Directors are elected. There is a difference also within the 19 elected Executive Directors as 3 of them represent single countries as is the case with China, Saudi Arabia and the Russian Federation, while the remaining 16 Executive Directors represent groups of IMF countries. As a result of this division, 8 Executive Directors represent single countries, while 16 Directors represent not a country but a group of countries, members of the IMF. Such unequal representation between countries is not in compliance with the principle of equality of states. The existing IMF reforms can be observed as amelioration of some of the inequalities in representation and voting power between IMF members and as such they are in line with the principle of equality of states. However, at the same time due to the fact that they do not introduce equality in representation and voting power they can also be seen as reforms that only update the existing weighted voting system according to the changes in the economies of certain countries.

With regard to suspension and forced withdrawal (expulsion), the majority decision-making processes requiring a majority of seventy percent to suspend an IMF member, or eighty five percent majority to force a member to withdraw, represent a deviation from the principle of equality of states. In these cases not all IMF members are in the same position to be suspended or forced to withdraw. The chances for being suspended or forced to withdraw are proportionality aligned to the voting power of IMF members. The greater the voting power, the smaller the chances for forced expulsion.

Withdrawal from the IMF is in line with the principle of equality of states as all IMF members can equally do so.

To sum up, economic IGOs such as the IMF present the most serious test of world government as they adopt decisions that have direct and immediate effect on world economy, which may affect national policies, therefore "enlightened approaches to decisionmaking in these organizations, including safeguards for weaker states, will ensure the ultimate success of this experiment". ${ }^{957}$

${ }^{957}$ Stephen Zamora, Voting in International Economic Organizations, 74 Am. J. Int’l. L. 566 (1980), pg. 608. 


\section{CHAPTER VII CONCLUSION}

\section{GENERAL OBSERVATIONS}

The principle of equality of states in international law originated from the municipal law ideal and legal principle of equality of men which, by analogy, transformed into the legal principle of equality of states. In legal doctrine authors such as Oppenheim, Brownlie, Cassese, and Shaw consider the principle of equality of states as one of the most important principles of international law. For Oppenheim the principle of equality of states represents the "indispensable foundation of international society" ${ }^{258}$, to Brownlie this principle represents the "basic constitutional doctrine of the law of nations" Cassese considers it "the linchpin of the whole body of international legal standards, the fundamental premise on which all international relations rest" ${ }^{\prime 960}$, and Shaw considers it to be a "crucial principle" ${ }^{\text {"61 }}$ of international law. A number of international law instruments also have direct references to the principle of equality of states including: the Montevideo Convention on Rights and Duties of States, the Declaration on Principles of International Law concerning Friendly Relations and Co-operation among States, the Charter of Economic Rights and Duties of States, and the Final Helsinki Act. Moreover, the Vienna Convention on the Representation of States in their Relations with International Organizations of a Universal Character refers to the principle of sovereign equality of states as a basic principle on which the Convention was drafted.

The principle of equality of states is an "umbrella" type of principle, in that it covers a wide range of matters. The debate between scholars on the meaning of the principle of equality of states in international law is usually focused on the discussion whether the principle of equality of states means either equality before the law or equal capacity for rights and obligations which may also mean equality of rights and obligations. In international law, the principle of equality of states means that every state is equal in its relations to other states. It does not mean that states are equal in any power determining parameters; it is not a principle of equally powerful states, but a principle of equality in relations between states, in their rights and obligations. As a principle of international

\footnotetext{
${ }^{958}$ L. Oppenheim, The Future of International Law, Carnegie Endowment for International Peace, Pamphlet No. 39, 1921, pg. 20.

${ }^{959}$ Ian Brownlie, Principles of International Law, Fourth Edition, Oxford University Press, 1990, pg. 287.

${ }^{960}$ Antonio Cassese, International Law, Second Edition, Oxford University Press, 2005, pg. 46.

${ }^{961}$ Malcolm N. Shaw, International Law, Sixth Edition, Cambridge University Press, 2008, pg. 214.
} 
law the principle of equality of states applies to the law of international organizations, as the latter is a branch of international law.

In international organizations the principle of equality of states originated from international conferences which adopted unanimity decision-making and the principle of one-state one-vote. Over time, the principle became part of constitutions of international organizations. Before World War II, the principle of equality of states was present through the unanimity rule in the Covenant of the League of Nations and the equality of voting powers and representation in the Assembly. After World War II the principle of equality of states was established as the first principle of the UN Charter by stating that "the organization is based on the principle of sovereign equality of all its members." Regionally, there are direct references to the principle of equality of states among others in the Charter of the Organization of American States, the OPEC Statute, and the ASEAN Charter. In municipal law, in states such as Italy and Greece, the application of the principle of equality of states in international organizations represents a constitutional obligation.

Unlike the debate on the meaning of the principle of equality of states in international law, the debate on the meaning of the principle of equality of states in international organizations is rather simple. The principle of equality of states in international organizations means equality of rights and duties of member states of international organizations. The principle of equality dictates same rights and duties without discrimination for all members. ${ }^{963}$ In discussing the meaning of the concept of 'sovereign equality' as one of the emanations of the principle of equality of states, a distinction should be made whether the focus of the discussion is sovereignty or equality of states. Having in mind that it is not always easy to make the distinction whether the discussion is about 'sovereignty' or 'equality' caution should be exercised in the review of the principle of equality of states in IGOs. The review of the principle of equality of states should focus on the concept of equality of states and not sovereignty. Sovereignty has always been a dynamic concept whose meaning has been constantly changing. From the perspective of the principle of equality of states, erosion of sovereignty does not necessarily result in erosion of equality of states if such erosion of sovereignty is equally applicable to all states. This is not so obvious at all times.

A significant difficulty to the application of the principle of equality of states in IGO is to find out how much are states equal in their rights and duties in international organizations. Or, how much equality of states there is between states as a result of their equal capacity for rights. ${ }^{964}$ Therefore, in order to discuss how much equality of states there is between states as a result of their equal capacity for rights, it is important to

\footnotetext{
${ }^{962}$ UN Charter, Article 2, para. 1.

963 Konstantinos D. Magliveras, 'Membership in international organizations' in Jan Klabbers and Åsa Wallendahl, Editors, Research Handbook on the Law of International Organizations, Edward Elgar Publishing Limited, 2011, pg. 91.

${ }^{964}$ Bengt Broms, The Doctrine of Equality of States as Applied in International Organizations, Vammala Kirjapaino, 1959, pg. 18.
} 
determine the scope of review of the principle of equality of states in international organizations.

\section{THE REVIEW OF THE PRINCIPLE OF EQUALITY OF STATES IN INTERNATIONAL ORGANIZATIONS}

The most relevant question to this inquiry encompasses the following: what does a review of the principle of equality of states in international organizations entail, what should be under review in international organizations in order to address this question?

After discussing the references to the principle of equality of states in the founding treaties of international organisations, in order to review the principle of equality of states in international organizations, this book takes a comprehensive and innovative approach to the discussion of the principle of equality of states in international organizations by addressing three sets of questions. These three sets of questions discuss: acquisition of membership (entering the IGO either as an original member through the negotiations process or through the admission/accession process); rights and obligations while being a member of an international organization (reflected in the representation of states, decision-making processes, equality of votes and financing); and suspension or termination of membership (being in the exit hallway with frozen membership through suspension, or exiting the international organization by expulsion or withdrawal).

When it comes to the process of acquisition of membership, the discussion on the principle of equality of states in international organizations should include the process of becoming a member through participating in the negotiations on the establishment of the IGO and potentially acquiring original membership, as well as through accession or admission. The coherence of the criteria for membership with the principle of equality of states, or the lack of it, can be best observed by reviewing whether the law of the IGO and its application in practice with regard to acquisition of membership results in equality or inequality between member states, i.e. the difference in their rights and duties. In this regard, it is important to review the negotiations for the establishment of the IGO and the possibility of acquiring original membership in the organization. Participation in the preparatory work, even if it does not grant original membership rights, provides for a valuable opportunity to influence decisions and offers psychological advantages in comparison with the members that join the organization after it is established. Moreover, a discussion on the principle of equality of states in the negotiations for the establishment of IGOs are also important due to the fact that they provide information on the role and the position of the principle of equality of states in the IGO to be established, as well as the position of states toward the principle in the process.

After the organization is established, with regard to the rights and duties of members, i.e. the existing members, it is important to review whether there is equality between members in four distinct, yet related categories: representation, decisionmaking processes, voting power and financing. 
With regard to the rights and obligations of states, of paramount importance to the application of the principle of equality of states is the right to representation. Without representation, no state can neither vote in a majority vote, nor block a decision in unanimity or consensus decision-making. In the application of the principle of equality of states with regard to representation, it is important to review whether all members are, or have the potential equally to be, represented in all organs. In compliance with the principle of equality of states, all states should have equal representation or a potential for equal representation.

Although the decision-making processes of IGOs are central to many discussions on the principle of equality of states, in fact, they are irrelevant for the application of the principle of equality of states as long as there is equality in representation and voting power. International organizations resort either to unanimity, majority, consensus, or a combination of these decision-making processes. There are authors that consider only unanimity and consensus decision-making to be in compliance with the principle of equality of states and wrongly exclude majority decision-making as a process in deviation from the principle of equality of states. Majority decision-making, when based on "equal representation and voting power" of all members is also in compliance with the principle of equality of states. When states consented to majority decision-making they also consented to accept decisions that they did not approve. Bearing in mind that all states have equal say in the decision-making process, and that they can equally be part of the "majority" or of the "minority" in the decision adopted, there is no deviation from the principle of equality of states. As a result, all decision-making processes, whether unanimity, consensus or majority decision-making are in line with the principle of equality of states if there is equal representation and voting powers of member states. Therefore, the decision-making process in fact is eventually irrelevant for the application of the principle of equality of states. It is not the decision-making process itself that determines (non)compliance with the principle of equality of states, it is in fact the (in)equality of representation and voting power which determines whether the decisionmaking process used in an IGO is in (non) compliance with the principle of equality of states.

With regard to voting power, there is compliance with the principle of equality of states as long as there is equal voting power between all states. This proposition is often formulated as the "one state, one vote" principle. The alternative to the one state one vote principle is the weighted voting and is not in compliance with the principle of equality of states as any inequality in voting power represents a clear deviation from the principle of equality of states. However, at times there may be strong incentives to introduce some type of a weighted voting system based on a number of parameters (whether separate or combined) to reflect differences between states and their voting powers in IGOs.

While the main focus on the principle of equality of states is on the equality of rights, there is a significant lack of attention to the principle of equality of states in 
international organizations when it comes to the equality of duties of states. An obvious reality is that when it comes to financing, economically more advanced states carry a greater financial responsibility. This has been the case from the time of the League of Nations requiring for the expenses needed for its functioning to be borne by the members “in the proportion decided by the Assembly". For example, the 10 largest contributors of the UN budget provide for $71.286 \%$, while the remaining 183 members provide for $28.714 \%$ of the UN budget. In similar terms, the 10 largest contributors of the WTO budget together participate with $55.12 \%$ of the total WTO budget, while the remaining members participate with $44.87 \%$ of the WTO annual budget.

The principle of equality of states also applies in situations when membership is either limited (as in cases of suspension) or when it comes to an end (as in cases of termination of membership either by expulsion or withdrawal). With regard to suspension, expulsion or withdrawal it is important to review whether all member states are equal in the decision-making (representation, equality of voting powers) process both when the related rules are applied to them, or, if they apply the rules to other members of the IGO.

\section{CONCLUSION}

The principle of equality of states is one of the cornerstones of international law and of the law of international organizations. Contrary to the inequality of members in IGOs, equality derives from the law. And not from any kind of law, but from natural law which is inherent to human beings by reason and nature. Hugo Grotius once stated: "all things are uncertain the moment men depart from law" and that "if no association of men can be maintained without law...surely that association which binds together the human race, or binds many nations together, has need of law". 965 The law can address a great deal of inequalities through establishing an international institutional system based on the rule of law and respect for the basic tenets of international law such as the one of the equality of states.

However, this is easier said than done. The principle of equality of states is an ideal; it is not absolute and cannot be established fully and immediately. As Kooijmans noted, equality is a mathematical notion which when drawn into the legal sphere results in a "doctrine completely at odds with reality, which, of necessity, will involve opposition since reality cannot be forced into a certain conception”. ${ }^{966}$ However, he continues, "it is entirely wrong to pass by and reject a principle so strongly related to legal conviction as is equality because it is said not to conform to reality". ${ }^{967}$

965 Hidemi Suganami, 'Grotius and International Equality’ in Hedley Bull, Benedict Kingsbury, Adam Roberts, Editors, Hugo Grotius and International Relations, Oxford University Press, 1990, pg, 224.

${ }^{966}$ Peter H. Kooijmans, The Doctrine of Legal Equality of States: An Inquiry Into the Foundations of International Law, A. W. Sythoff, 1964, pg. 2.

${ }^{967}$ Ibid., pg. 3. 
The fact that there are such overwhelming differences between states among others in the size of their territory, economic and military development, education and technology, population or almost any other parameter, does not make the application of the principle of equality of states in international organizations easy, or at times, viable and realistic. The significant disparities between states with regard to population size, GPD and territory show that a majority of 173 UN Members having 173 votes or $89.63 \%$ of the total votes (out of the 193 in total), represent "only" $29 \%$ of the world population, $19.1 \%$ of world GDP and $32.71 \%$ of the territory of states per sq. $\mathrm{km}$. The remaining 20 UN Members having 20 votes or $10.36 \%$ of the total votes represent: $71 \%$ of the world population, $80.9 \%$ of world GDP and $67.29 \%$ of the territory of states per sq. km. Out of these parameters, the exclusion of the population size as a criterion for a weighted voting system in IGOs creates an intriguing paradox. Namely, the application of the principle of equality of states (developed through the analogy of equality of men) requiring equality of voting power and representation results in significant inequality between men. According to the principle of equality of states in IGOs, the most populous states of the world such as China and India which combined have a population of around 2.5 billion people are entitled to equal representation and voting power as the least populous states such as Tuvalu and Nauru which combined have a population of around twenty thousand people. To illustrate, the 1.35 billion Chinese, or the 310 million Americans under the principle of equality of states are entitled to equal representation and voting power as are the 20.000 inhabitants of Palau or the 10.000 inhabitants of Nauru.

As a result, the greater the size of the population of a state, the greater is the inequality of representation and voting power compared to states that have smaller population size. This is a paradoxical result as obviously men are considered equal under municipal law and international law alike but are not equal in representation and voting power in IGOs. Perhaps there is some justification that in this case we are not addressing the rights of men as individuals but their collective rights as nations represented by states. Another justification would also be that it would not be an easy task for states to agree for a weighted voting system based on the size of their population. One aspect to consider here is the fact that around $60 \%$ of the world population lives in Asia and it would be difficult to convince the remaining states outside of Asia that they would be entitled to 'only' around $40 \%$ of representation and voting power if a universal IGO would consider population size as its main criteria for introducing a weighted voting system. Be it as it may, the discrepancy in the population size between states is so significant that it represents a considerable difficulty in the application of the principle of equality of states. Moreover, the result is also paradoxical as it creates inequality between men as individuals on the world scale. In a world community of men which may probably take place if and when states would seize to exist, "equality of men" and not the "equality of states" would be the principle to enforce (in a dimension beyond the scope of this book). 
Having in mind such realities, at times there may be strong incentives to introduce some type of a weighted voting system and/or limited representation based on a number of parameters (whether separate or combined) to reflect differences between states and their voting powers in IGOs. For example, at the current stages of development of the international community, the Security Council will obviously continue to be in deviation from the principle of equality of states due to the limited representation of UN Members and the veto powers of the permanent five. Even a reformed Security Council will most likely (not to say certainly) continue to be in deviation from the principle of equality of states as there is no discussion or a possibility for the Security Council to provide for equality of representation and voting powers for all UN members. Another example of an existing deviation from the principle of equality of states which will unlikely be eradicated in foreseeable future is the inequality of financing of IGOs. What is intriguing is that even supporters of the principle of equality of states in international organizations do not address in great detail the inequality of financing of international organizations. If any weighted voting system is in deviation from the principle of equality of states in IGOs, a weighted financing system of IGOs is also in deviation from the principle of equality of states. None of the IGOs discussed in this book have introduced equality of financial obligations for their members and are in deviation from the principle of equality of states.

On the other hand, in international organizations such as the IMF, there is room for further amelioration of the existing inequalities between states. While it is not the objective of this book to come up with specific models that are more in compliance with the principle of equality of states for specific IGOs, as discussed, the weighted voting that existed in the International Institute of Agriculture (IIA) or the International Bureau of Industrial Property (IBIP) seem to offer some comparative advantage in the application of the principle of equality of states. Their weighted voting system of the IIA and IBIP provided equal opportunity for all members to choose by their own desire the membership category to be assigned to them knowing beforehand the specific rights and obligations each category entails. Such an equal opportunity for all states to choose beforehand the specific rights and obligations each category entails, has also implications for the principle of equality of states. From a formal legal perspective, all states have equal opportunity to choose any category of membership and therefore this particular model of weighted voting is in compliance with the principle of equality of states. In addition, such a system of weighted voting may also have an additional comparative advantage if it would introduce a dynamic (not static) model by allowing states to shift from one category of membership into another depending on their development (economic, military or other). This is hardly possible in many IGOs that take a more static approach and require difficult amendments of their founding treaties in order for such membership shifts to occur. However, the difficulty here is that states that have more resources have a better chance to choose categories that provide them with more rights and obligations in comparison to states that have more limited resources. As a result, the 
weighted voting system provided, results in inequality of states in these international organizations with regard to equality of votes. However, such a model may prove very useful to ameliorate some of the inequalities in IGOs where the use of the weighted voting system does not even provide for an opportunity for states to choose by their own desire the category entailing specific rights and obligations in an IGO.

Finally, quite different from the examples of deviation from the principle of equality of states, the case of the WTO proves that there may be a successful universal IGO which is formally is in line with the principle of equality of states. As discussed, the WTO provides equality in representation and voting power for all its members. The fact that the WTO was established at a time of relative world peace (unlike the UN and the IMF established during and in the aftermath of WWII) seems to have played an important role for such an outcome. This can be clearly seen from the fact that the Havana Charter of the International Trade Organization in 1948 did provide for a non-plenary organ (the Executive Board), and this is clearly not the case in the Marrakesh Agreement establishing the WTO in 1995. From this perspective, it can also be argued that the deviation from the principle of equality of states in IGOs may more likely occur in times of crisis of the international community in comparison to circumstances of relative world peace. 


\section{BIBLIOGRAPHY}

\section{BOOKS, BOOK CHAPTERS, MONOGRAPHS}

Amerasinghe, C. F., Principles of the Institutional Law of International Organizations, Second Edition, Cambridge University Press, 2005.

Anand, R. P., Sovereign Equality of States and International Law, Hope India Publications, 2008.

Baehr, Peter R. and Gordenker, Leon, The United Nations: Reality and Ideal, Fourth Edition, Palgrave Macmillan, 2005.

Basic Facts about the United Nations, United Nations Department of Public Information, New York, 2011.

Bookmiller, Kirsten Nakjavani, The United Nations (Global Organizations), Chelsea House Publishers, New York, 2008.

Boughton, James M., Silent Revolution: The International Monetary Fund, 1979-1989, The International Monetary Fund, 2001.

Broms, Bengt, The Doctrine of Equality of States as Applied in International Organizations, Vammala Kirjapaino, 1959.

Brownlie, Ian, Principles of International Law, Fourth Edition, Oxford University Press, 1990.

Brownlie, Ian, Principles of Public International Law, Sixth Edition, Oxford University Press, 2003.

Busch, Marc L., and Reinhardt, Eric, 'Developing Countries and GATT/WTO Dispute Settlement' in George A. Berman and Petros C. Mavroidis, Editors, WTO Law and Developing Countries, Cambridge University Press, 2007.

Cassese, Antonio, International Law, Second Edition, Oxford University Press, 2005.

Cede, Franz, 'Historical and Legal Framework for Activities of the United Nations' in Franz Cede and Lilly Sucharipa-Behrmann, Editors, The United Nations Law and Practice, Kluwer Law International, 2001.

Claude, Inis L., Swords into Plowshares: The Problems and Progress of International Organizations, Fourth Edition, Random House, 1971.

Conforti, Benedetto and Focarelli, Carlo, The Law and Practice of the United Nations, Fourth Revised Edition, Martinus Nijhoff Publishers, 2010.

Cottier, Thomas, and Takenoshita, Satoko, 'Decision-Making and the Balance of Powers in WTO Negotiations: Towards Supplementary Weighted Voting’, in Stef- 
an Griller, Editor, At the Crossroads: The World Trading System and the Doha Round, Springer, 2008.

Crawford, James R., The Creation of States in International law, Second Edition, Oxford University Press, 2007.

Davey, William J., 'Institutional Framework' in Patrick F. J. Macrory, Arthur E Appleton, Michael G. Plummer, Editors, The World Trade Organization: Legal, Economic and Political Analysis, Volume I, Springer 2005.

de Vries, Margaret Garritsen, IMF in a Changing World: 1945-85, International Monetary Fund, 1986.

Dickinson, Edwin DeWitt, The Equality of States in International Law, Harvard University Press, 1920.

Driscoll, David D., What is the International Monetary Fund?, International Monetary Fund, 1998.

Duxbury, Alison, The Participation of States in International Organizations, the Role of Human Rights and Democracy, Cambridge University Press, 2011.

Efraim, Athena Debbie, Sovereign (In)equality in International Organizations, Martinus Nijhoff, 2000.

Financial Organization and Operations of the IMF, Treasurer's Department, International Monetary Fund 2001, IMF Pamphlet Series No. 45, Sixth Edition, Treasurer's Department, International Monetary Fund, 2001.

Footer, Mary E., An Institutional and Normative Analysis of the World Trade Organization, Martinus Nijhoff Publishers, 2006.

Gazzini, Tarcisio, 'Personality of International Organizations’ in Jan Klabbers and Åsa Wallendahl, Editors, Research Handbook on the Law of International Organizations, Edward Elgar Publishing Limited, 2011.

Goebel, Julius Jr., The Equality of States: A Study in the History of Law. Columbia University Press, New York, 1923.

Gold, Joseph, Interpretation: The IMF and International Law, Kluwer Law International, 1996.

Gold, Joseph, Membership and Nonmembership in the International Monetary Fund: a study in international law and organization, International Monetary Fund, 1974.

Grant, Thomas D., Admission to the United Nations: Charter Article 4 and the Rise of Universal Organization, Martinus Nijhoff Publishers, 2009.

Groom, A. J. R., 'Getting to 'Go': The Birth of the United Nations System', in Paul Taylor and A. J. R. Groom, Editors, The United Nations at the Millennium: The Principal Organs, Continuum International Publishing Group, 2000.

Grynberg, Roman, Dugal, Manleen, and Razzaque, Mohammad A, An Evaluation of the Terms of Accession to the World Trade Organization, A Comparative Assessment of Services and Goods Sector Commitments by WTO Members and Acceding Countries, Economic Paper 73, Commonwealth Secretariat, 2006.

Hart, H. L. A., The Concept of Law, Oxford University Press, Second Edition, 1994. 
Hilderbrand, Robert C., Dumbarton Oaks: The Origins of the United Nations and the Search for Postwar Security, The University of North Carolina Press, 1990.

Houtven, Leo Van, Governance of the IMF: Decision-making, Institutional Oversight, Transparency, and Accountability, Pamphlet Series No. 53, International Monetary Fund, 2002.

IMF Quota and Governance Reform-Elements of an Agreement -IMF Finance Legal, Strategy, Policy and Review Departments, October 2010.

Irwin, Douglas A., Mavroidis, Petros C., and Sykes, Alan O. The Genesis of the GATT, Cambridge University Press, 2008.

Jackson, John H., Sovereignty, the WTO and Changing Fundamentals of International Law, Cambridge University Press, 2006.

Jackson, John H., The World Trading System: Law and Policy of International Economic Relations, Second Edition, MIT 1997.

Jennings and Watts, Oppenheim's International Law, Ninth Edition, Volume I, Peace: Introduction and Part I, Published by Addison Wesley Longman, 1997.

Kelsen, Hans, The Law of the United Nations: A Critical Analysis of its Fundamental Problems, With Supplement, Stevens \& Sons Limited, 1951.

Kingsbury, Benedict, 'Sovereignty and Inequality' in Andrew Hurrell and Ngaire Woods, Editors, Inequality, Globalization, and World Politics, Oxford University Press, 1999.

Klabbers, Jan, 'Contending approaches to International Organizations: Between functionalism and constitutionalism' in Jan Klabbers and Åsa Wallendahl, Editors, Research Handbook on the Law of International Organizations, Edward Elgar Publishing Limited, 2011.

Klabbers, Jan, An Introduction to International Institutional Law, Second Edition, Cambridge University Press, 2009.

Klein, Robert A., Sovereign Equality Among States: The History of an Idea, University of Toronto Press, 1974.

Kooijmans, Peter H., The Doctrine of Legal Equality of States: An Inquiry Into the Foundations of International Law, A. W. Sythoff, 1964.

Lowenfeld, Andreas F., International Economic Law, Second Edition, Oxford University Press, 2008.

Magliveras, Konstantinos D., 'Membership in international organizations' in Jan Klabbers and Åsa Wallendahl Editors, Research Handbook on the Law of International Organizations, Edward Elgar Publishing Limited, 2011.

Magliveras, Konstantinos D., Expulsion from Participation in International Organizations: The Law and Practice Behind Member States’ Expulsion and Suspension of Membership, Kluwer Law International, 1999.

Martinez, Magdalena M. Martin, National Sovereignty and International Organizations, Kluwer Law International, 1996. 
Matsushita, Mitsuo, Schoenbaum, Thomas J., and Mavroidis, Petros C., The World Trade Organization: Law, Practice and Policy, Oxford University Press, 2006.

Meagher, Niall, 'Representing Developing Countries in WTO Dispute Settlement Proceedings' in George A. Berman and Petros C. Mavroidis, Editors, WTO Law and Developing Countries, Cambridge University Press, 2007.

Moore, Mike, 'The Democratic Roots of the World Trade Organization' in Patrick F. J. Macrory, Arthur E Appleton, Michael G. Plummer, Editors, The World Trade Organization: Legal, Economic and Political Analysis, Volume I, Springer 2005.

Oppenheim, L., The Future of International Law, Carnegie Endowment for International Peace, Pamphlet No. 39, 1921.

Portugal, Murilo, 'Improving IMF Governance and Increasing the Influence of Developing Countries in IMF Decision-Making', in Ariel Buria, Editor. Reforming the Governance of the IMF and the World Bank, Anthem Press, 2005.

Ragazzi, Maurizio, The Concept of International Obligations Erga Omnes, Oxford University Press, 2002.

Reis, Ronald A., The World Trade Organization (Global Organizations), Chelsea House Publishers, 2009.

Riesenhuber, Eva, The International Monetary Fund Under Constraint: Legitimacy of its Crisis Management, Kluwer Law International, 2001.

Roth, Brad R. Sovereign Equality and Moral Disagreement: Premises of a Pluralist International Legal Order, Oxford University Press, 2011.

Rousseau, Jean-Jacques, A Discourse Upon the Origin and the Foundation of the Inequality Among Mankind, 1755, published by Echo Library, 2007.

Sands, Philippe, and Klein, Pierre, Bowett's Law of International Institutions, Sixth Edition, Sweet \& Maxwell, 2009.

Schemeil, Yves, 'Consensus making within the World Trade Organization and the World Meteorological Organization' in Bob Reinalda and Bertjan Verbeek, Editors, Decision-making within International Organizations, Edward Elgar Publishing Limited, 2004.

Schermers, Henry G., \& Blokker, Niels M., International Institutional Law, Fifth Revised Edition, Martinus Nijhoff Publishers, 2011.

Schermers, Henry G., \& Blokker, Niels M., International Institutional Law: Unity Within Diversity, Fourth Revised Edition, Martinus Nijhoff Publishers, 2003.

Schlesinger, Stephen, Act of Creation: The Founding of the United Nations: A Story of Superpowers, Secret Agents, Wartime Allies and Enemies, and Their Quest for a Peaceful World, Westview Press, 2003.

Schwebel, Stephen M., Justice in International Law: Selected Writings, Cambridge University Press, 1994.

Seidl-Hohenveldern, Ignaz, International Economic Law, Third Edition, Kluwer Law International, 1999.

Shaw, Malcolm N. International Law, Sixth Edition, Cambridge University Press, 2008. 
Simma, Bruno, and Mosler, Hermann et al, Editors, The Charter of the United Nations:

A Commentary, Second Edition, Volume I, Oxford University Press, 2002.

Simpson, Gerry, Great Powers and Outlaw States: Unequal Sovereigns in the International Legal Order, Cambridge University Press, 2004.

Smouts, Marie-Claude, 'The General Assembly: Grandeur and Decadence' in Paul Taylor and A. J. R. Groom, Editors, The United Nations at the Millennium: The Principal Organs, Continuum International Publishing Group, 2003.

Stone, Randall W., Controlling Institutions: International Organizations and the Global Economy, Cambridge University Press, 2011.

Suganami, Hidemi, 'Grotius and International Equality' in Hedley Bull, Benedict Kingsbury, Adam Roberts, Editors, Hugo Grotius and International Relations, Oxford University Press, 1990.

Sutherland, Peter, et al. The Future of the WTO: Addressing Institutional Challenges in the New Millennium (The Sutherland Report), Geneva: WTO, 2004.

Van den Bossche, Peter, and Zdouc, Werner The Law and Policy of the World Trade Organization: Text, Cases and Materials, Third Edition, Cambridge University Press, 2013.

Van den Bossche, Peter, The Law and Policy of the World Trade Organization: Text, Cases and Materials, Second Edition, Cambridge University Press, 2008.

Volger, Helmut, 'History of the Foundations of the UN' in Helmut Volger, Editor, A Concise Encyclopedia of the United Nations, Second Revised Edition, Martinus Nijhoff Publishers, 2010.

Volger, Helmut, 'Secretariat' in Helmut Volger, Editor, A Concise Encyclopedia of the United Nations, Second Revised Edition, Martinus Nijhoff Publishers, 2010.

Warbrick, Colin, 'The principle of sovereign equality' in Colin Warbrick and Vaughan Lowe, Editors, The United Nations and the Principles of International Law, Essays in Memory of Michael Akehurst, Routledge, 1994.

Westlake, John, Chapters on the Principles of International Law, Cambridge University Press, 1894.

What is the IMF? International Monetary Fund: Making the Global Economy Work for All, International Monetary Fund, 2006.

White, Nigel D., 'Decision-making' in Jan Klabbers and Åsa Wallendahl, Editors, Research Handbook on the Law of International Organizations, Edward Elgar Publishing Limited, 2011.

Williams, Peter John, A Handbook on Accession to the WTO, A WTO Secretariat Publication, Cambridge University Press, 2008.

Winham, Gilbert R., 'An Interpretative History of the Uruguay Round Negotiations' in Patrick F. J. Macrory, Arthur E Appleton, Michael G. Plummer, Editors, The World Trade Organization: Legal, Economic and Political Analysis, Volume I, Springer 2005. 
Woods, Ngaire, 'The United States and the International Financial Institutions: Power and Influence Within the World Bank and the IMF' in Rosemary Foot, S. Neil MacFarlane and Michael Mastanduno, Editors, US Hegemony and International Organizations: The United States and Multilateral Institutions, Oxford University Press, 2003.

World Trade Organization, Understanding the WTO, Fifth edition, published by the WTO, 2011.

Wouters, Jan, and Mann, De Philip, 'International organizations as law-makers' in Jan Klabbers and Åsa Wallendahl, Editors, Research Handbook on the Law of International Organizations, Edward Elgar Publishing Limited, 2011.

WTO Analytical Index - Guide to WTO Law and Practice, Sixth Edition, WTO Secretariat, 2012. 


\section{ARTICLES}

Amerashinghe, C. F., International Institutional Law - A Point of View, 5 Int'll. Org. L. Rev. 143 (2008).

Armstrong, S. W., The Doctrine of the Equality of Nations in International Law and the Relation of the Doctrine to the Treaty of Versailles, 14 Am. J. Int'l. L. 540 (1920).

Baker, P. J., The Doctrine of Legal Equality of States, 4 Brit. Y. B. Int'l. L. 1 (19231924).

Blokker, Niels, Comparing Apples and Oranges? Reinventing the Wheel? Schermers' Book and Challenges for the Future of International Institutional Law, 5 Int'l. Org. L. Rev. 197 (2008).

Blokker, Niels, International Organizations and Their Members, 1 Int'l. Org. L. Rev. 139 (2004).

Blokker, Niels, International Organizations and Their Members, 1 Int'l. Org. L. Rev. 139 (2004).

Borchard, Edwin, The Dumbarton Oaks Conference, 39 Am. J. Int'l. L. 97 (1945).

Briggs, Herbert W., Membership in the Proposed General International Organization, 39 Am. J. Int’l. L. 101 (1945).

Briggs, Herbert W., Power Politics and International Organization, 39 Am. J. Int'l. L. 664 (1945).

Brölmann, Catherine, A Flat Earth? International Organizations in the System of International Law, 70 Nordic J. Int'l. L. 319 (2001).

Bronz, George, The International Trade Organization Charter, 62 Harv. L. Rev. 1089 (1949).

Brown, Philip Marshall, The Theory of the Independence and Equality of States, 9 Amer. J. Int’l. L. 305 (1915).

Burns, Josephine Joan, Conditions of Withdrawal from the League of Nations, 29 Am. J. Int'l. L. 40 (1935).

Byers, Michael, Raghavan, Vikram, and Becerra-Ramirez, Manuel, Voices from the Outside: Sovereign Equality, International Law and the Balance of Power, ASIL Proceedings, 2005.

Claude, Inis L. Jr., A Scholar's Beginnings: A Study of the San Francisco Charter, 40 Va. J. Int'l. L. 311 (1999-2000).

Claude, Inis L. Jr., Introduction: The Central Challenge to the United Nations: Weakening the Strong or Strengthening the Weak? 14 Harv. Int'l. L. J. 516 (1973).

Claude, Inis L. Jr., The Management of Power in the Changing United Nations, 15 Int'l. Org. 219 (1961).

Cogan, Jacob Katz, Representation and Power in International Organization: The Operational Constitution and its Critics, 103 Am. J. Int'l. L. 209 (2009).

Cullet, Philippe, Differential Treatment in International Law: Towards a New Paradigm of Inter-state Relations, 10 Eur. J. Int'l. L. 549 (1999). 
Dunoff, Jeffrey L., Is Sovereign Equality Obsolete? Understanding Twenty-First Century International Organizations, 43 Neth. YBIL 99 (2013).

Fineman, Martha Albertson Equality Across Legal Cultures: The Role for International Human Rights, 27 T. Jefferson L. Rev. 1 (2004-2005).

Fletcher, George P., In God's Image: The Religious Imperative of Equality under Law, 99 Colum. L. Rev. 1608 (1999).

Franck, Thomas M., Legitimacy in the International System, 82 Am. J. Int'l. L. 705 (1988).

Gardner, Richard N., United Nations Procedures and Power Realities: The International Apportionment Problem, 59 Proc. Am. Soc. Int'l. L. 232 (1965)

Goebel, Julius Jr., The Equality of States II, 23 Colum. L. Rev. 113 (1923).

Goebel, Julius Jr., The Equality of States, 23 Colum. L. Rev. 1 (1923).

Goebel, Julius Jr., The Equality of States, 23 Colum. L. Rev. 247 (1923).

Gunter, Michael M., What Happened to the United Nations Ministate Problem, 71 Am. J. Int'l. L. 110 (1977).

Herrera, Roberto, Evolution of Equality of States in the Inter-American System, 61 Polit. Sci. Quart. 90 (1946).

Hexner, Ervin P., The Executive Board of the International Monetary Fund: A Decision-Making Instrument, 18 Int'l. Org. 74 (1964).

Hillgruber, Christian, The Admission of New States to the International Community, 9 Eur. J. Int. L. 491 (1998).

James, Alan, The Equality of States: Contemporary Manifestations of an Ancient Doctrine, 18 Rev. Int'l. Stud. 377 (1992).

Jenks, C. Wilfred, The Equality of Man in International Law, 13 Howard L. J. 321 (1967).

Kao, William Timothy, The Equality of States, 3 China L. Rev. 112 (1926-1929).

Kelsen, Hans, Membership in the United Nations, 46 Colum. L. Rev. 391 (1946).

Kelsen, Hans, The Principle of Sovereign Equality of States as a Basis for International Organization, 53 Yale L. J. 207 (1943-1944).

Kirgis, Frederic L. Jr., The Security Council’s First Fifty Years, 89 Am. J. Int'l. L. 506 (1995).

Klabbers, Jan, Constitutionalism Lite, 1 Int'l. Org. L. Rev. R. 31 (2004).

Klabbers, Jan, Life and Times of the Law of International Organizations, 70 Nordic J. Int'l. L. 287 (2001).

Kokott, Juliane, States, Sovereign Equality, Max Planck Encyclopedia of Public International Law.

Krisch, Nico, International Law in Times of Hegemony: Unequal Powers and the Shaping of the International Legal Order, 16 Eur. J. Int'l. L. 369 (2005).

Lamy, Pascal, The Place of the WTO and its Law in the International Legal Order, 17 Eur. J. Int'l. L. 969 (2007). 
Langhammer Rolf J., and Lücke, Matthias, WTO Accession Issues, Kiel Institute of World Economics, Working Paper No. 95, February 1999.

Lowenfeld, Andreas F., The International Monetary System: A Look Back Over Seven Decades, 13 J. Int'l. Econ. L. 575 (2010),

McIntyre, Elizabeth, Weighted Voting in International Organizations, 8 Int'l. Org. L. Rev. 484 (1954).

McNair, Arnold D., Equality in International Law, 26 Mich. L. Rev. 131 (1927-1928).

McNicoll, Geoffrey, Population Weights in the International Order, 25 Popul. Dev. Rev. 411 (1999).

Meier, Gerald M., The Bretton Woods Agreement-Twenty Five Years After, 23 Stan. L. Rev. 235 (1971).

Nijman, Janne E. and Werner, Wouter G., Legal Equality and the International Rule of Law, 43 Neth. YBIL 3 (2013).

Osieke, Ebere, Admission to Membership in International Organizations: The Case of Namibia, 51 Brit. Y. B. Int’l. L. 189 (1980).

Osieke, Ebere, Majority Voting Systems in the International Labour Organisation and the International Monetary Fund, 33 Int'l. Comp. L. Quart. 381 (1984).

Pehle, John W., The Bretton Woods Institutions, 55 Yale L. J. 1127 (1946).

Posner, Eric A., and de Figueiredo, Miguel F. P., Is the International Court of Justice Biased?, 34 J. Legal Stud. 599 (2005).

Preuß, Ulrich K., Equality of States-Its Meaning in a Constitutionalized Global Order, 9 Chi. J. Int'l. L. 17 (2008-2009).

Roth, Brad R., Sovereign Equality and Non-Liberal Regimes, 43 Neth. YBIL 25 (2013).

Rudzinski, Aleksandar W., The So-Called Double Veto, 45 Am. J. Int’l. L. 443 (1951).

Schüller, A. and Hamel, H., Of the Membership of Socialist Countries in the International Monetary Fund, 34 Acta Oeconomica 113 (1985).

Schwelb, Egon, Withdrawal from the United Nations: The Indonesian Intermezzo, 61 Am. J. Int’l. L. 661 (1967).

Seibert-Fohr, Anja, The Rise of Equality in International Law and its Pitfalls: Learning from Comparative Constitutional Law, 35 Brook. J. Int'l. L. 1 (2010).

Simpson, Gerry, Great Powers and Outlaw States Redux, 43 Neth. YBIL 83 (2013)

Simpson, Gerry, The Great Powers, Sovereign Equality and the Making of the United Nations Charter, 21 Aust. YBIL 133 (2000).

Sohn, Louis B., Weighting of Votes in an International Assembly, 38 Am. Pol. Sci. Rev. 1192 (1944).

Steinberg, Richard H., In the Shadow of Law or Power? Consensus-Based Bargaining and Outcomes in the GATT/WTO, 56 Intl. Org. 339 (2002).

The Proposed International Trade Organization. Havana Conference on Trade and Employment, 1 Int'l. L. Quart. 541 (1947).

Thomas, Ann Van Wynen, and Thomas, A. J. Jr., Equality of States in International Law, Fact or Fiction, 37 Va. L. Rev. 791 (1951). 
Tijmes-LHL, Jaime, Consensus and majority voting in the WTO, 8:3 World Trade Review 417 (2009).

Weinsohel, Herbert, The Doctrine of the Equality of States and its Recent Modifications, 45 Am. J. Int'l. L. 417 (1951).

Wilcox, Clair, The London Draft of a Charter for an International Trade Organization, 37 Am. Econ. Rev. 529 (1947).

Williams, Talcott, The Misleading Myth of the Equality of Nations, 96 Annals of the American Academy of Political and Social Science, The Place of the United States in a World Organization for Maintenance of Peace, 124 (1921).

Wilson, Robert R., Proposed ITO Charter, 41 Am. J. Int’l. L. 879 (1947).

Wolfe, Robert, Decision-Making and Transparency in the "Medieval” WTO: Does the Sutherland Report Have the Right Prescription, 8 J. Int’l. Econ. L. 631 (2005).

Wright, Quincy, Equality of States, 3 Cornell Int'l. L. J. 1 (1970).

Zamora, Stephen, Voting in International Economic Organizations, 74 Am. J. Int’l. L. 566 (1980).

Zoller, Elisabeth, The "Corporate Will” of the United Nations and the Rights of the Minority, 81 Am. J. Int’l L. 610 (1987).

\section{INTERNATIONAL AND MUNICIPAL LEGAL INSTRUMENTS, REPORTS, AND OTHER DOCUMENTS}

Accession of Least-Developed Countries, WTO document WT/L/508, 20 January 2003.

Addendum to the 2002 LDC Accession Guidelines, WT/COMTD/LDC/21, July 2012.

Agreement Between the United Nations and the International Monetary Fund, November 15, 1947.

Arbitration Commission of the Conference on Yugoslavia, Opinion No. 1, 1991.

Articles of Agreement of the International Bank for Reconstruction and Development, 22 July, 1944.

Articles of Agreement of the International Monetary Fund, 22 July, 1944.

Assessment of Member State's contributions to the United Nations regular budget for the year 2011, United Nations Secretariat Document, ST/ADM/SER.B/824, 28 December 2010.

Atlantic Charter, August 14, 1941.

By-Laws of the International Monetary Fund, March 1946.

Charter of Paris for a New Europe, 1990.

Charter of the Organization of the American States, 1948.

Constitution of France.

Constitution of Greece.

Constitution of the FAO, 1945.

Constitution of the International Labour Organization, 01 April, 1919. 
Constitution of the Italian Republic.

Constitution of the World Health Organization, 1946.

Convention of the International Institute of Agriculture, 1905.

Covenant of the League of Nations, 1919.

Declaration by the United Nations, January 1, 1942.

Declaration of Independence, by Thomas Jefferson, US Congress, July 4, 1776.

Declaration of the Rights of Man and of the Citizen, Approved by the National Assembly of France, August 26, 1789.

Declaration of the Three Powers, the Tehran Conference, December 1, 1943.

Diversity Annual Report, International Monetary Fund, 2011.

Final Act of the United Nations Conference on Trade and Employment, Havana, Cuba, 1948.

GA Res 2625 (XXV) (1970). Declaration on Principles of International Law concerning Friendly Relations and Co-operation among States in accordance with the Charter of the United Nations.

GA Res 3281 (XXIX), (1974) Charter of Economic Rights and Duties of States.

GA Resolution, 47/1, 19 September 1992.

GA Resolution, 48 /26, 3 December 1993.

GA Resolution, 60/286, 8 September 2006.

GA Resolution, 66/14, 11 October 2011.

GA Resolutions on Admission of New Members, A/RES/296 B (IV) of 1949, A/RES/296 K (IV) of 1949.

General Agreement on Tariffs and Trade (GATT 1947).

General Agreement on Tariffs and Trade 1994.

General Agreement on Trade in Services.

German Hopes for UN Security Council Seat Dampened, Deutsche Welle, 20 August, 2004, at: http://www.dw-world.de/dw/article/0,,1302199,00.html, (visited March 2013).

Helsinki Final Act, 1975.

Inter-Allied Council Statement on the Principles of the Atlantic Charter, September 24, 1941.

International Trade Organization Charter, 1948.

Joint Four-Nation Declaration of the Moscow Conference, October 1943.

Kevin Watkins and Ngaire Woods, “Africa must be heard in the councils of the rich”, International Herald Tribune, October 1, 2004, available at: http://www.iht.com/bin/print.php?file=541501.html, (visited May 2013).

Montevideo Convention on the Rights and Duties of States 1933.

OPEC Statute, 1961.

Peter S. Goodman, "Bush to Pick Zoellik for World Bank”, The Washington Post, May, 30, 2007, available at http:/www.washingtonpost.com/wp-dyn/content/article/2007/05/29/AR2007052900760.html?hpid=topnews, (visited March 2013). 
Preliminary Draft Outline of a Proposal for an International Stabilization Fund of the United and Associated Nations, (White Plan) Revised July 10, 1943.

Preliminary Draft Proposal for a United Nations Stabilization Fund and a Bank for Reconstruction and Development of the United and Associated Nations (the White Plan), April, 1942.

Press Release No. 08/64, March 28, 2008, IMF Executive Board Recommends Reforms to Overhaul Quota and Voice.

Press Release No. 08/93, April 29, 2008, IMF Board of Governors Adopts Quota and Voice Reforms by Large Margin.

Press Release No. 10/418, November 5, 2010, IMF Executive Board Approves Major Overhaul of Quotas and Governance.

Press Release No. 11/64, March 3, 2011, The IMF’s 2008 Quota and Voice Reforms Take Effect.

Proceedings and Documents of the United Nations Monetary and Financial Conference, Bretton Woods, New Hampshire, July 1-22, 1944.

Proposals for an International Clearing Union (the Keynes Plan), April 1943.

Proposals for an International Currency (or Clearing) Union (the Keynes Plan), February $11,1942$.

Protocol of proceedings of Crimea Conference, February 1945.

Reform of Quota and Voice in the International Monetary Fund- Report of the Executive Board to the Board of Governors, International Monetary Fund, March 28, 2008.

Repertory of Practice of UN Organs, Extracts relating to Article 3 of the Charter of the United Nations, (1945-1954), volume 1, available at: http://untreaty.un.org/cod/repertory/art3.html (visited May 2013).

Repertory of Practice of United Nations Organs, Extracts relating to Article 5 of the Charter of the United nations, Supplement No 5 (1970-1978), Supplement No 6 (1979-1984), Supplement No 8 (1989-1994) volume 1, available at: http://www.un.org/law/repertory/, (visited May 2013).

Report of the Secretary-General, Composition of the Secretariat: staff demographics, A/66/347, 8 September 2011.

Report of the Special Committee on Principles of International Law Concerning Friendly Relations and Co-operation among States, United Nations Document A/5746 (November 16, 1964).

Report of the Working Party on the Accession of the Kyrgyz Republic, WT/ACC/KGZ/26, 31 July 1998.

Rules and Regulations of the International Monetary Fund.

Rules of Procedure of the General Assembly.

Rules of Procedure of the Security Council.

Special and Differential Treatment for Least-Developed Countries, Note by the WTO Secretariat, WT/COMTD/W/135 of 5 October 2004. 
Speech of Sir Winston Churchill, Zurich, 19th September 1946.

St. James Agreement of June 12, 1941

Statute of the International Court of Justice, 1945.

Technical note on the accession process, note by the Secretariat: State of Play and Information on Current Accessions, WT/ACC/11/Rev.10, 28 February 2012.

The "Iron Curtain Speech" by Winston Churchill at Westminster College, Fulton, Missouri, USA, March 5, 1946.

The ASEAN Charter, 2007.

UN Charter, 26 June 1945.

UN ECOSOC Res. 13. UN Doc E22 (1946).

United Nations Conference on the Law of Treaties, First session, Vienna, 26 March-24 May 1968, Official Records, Summary records of the plenary meetings and of the meetings of the Committee of the Whole, A/CONF.39/11.

United Nations Conference on the Law of Treaties, Second session, Vienna, 9 April-22 May 1969, Official Records, Summary records of the plenary meetings and of the meetings of the Committee of the Whole, A/CONF.39/ll/Add.l.

United Nations Population Division, Department of Economic and Social Affairs, World Population Prospects: The 2010 Revision, POP/DB/WPP/Rev.2010/02/F01, New York, 2011.

United Nations regular budget for 2012, United Nations Secretariat Document, ST/ADM/SER.B/853, 27 December 2011.

United Nations Security Council Resolution, S/RES/817 (1993).

Vienna Convention on the Law of Treaties, 1969.

Vienna Convention on the Representation of States in their Relations with International Organization of a Universal Character, 1975.

Woodrow Wilson’s “Fourteen Points” Speech, January 8, 1918.

Yearbook of International Law Commission 1966, Draft Articles on the Law of Treaties with commentaries.

Yearbook of International Law Commission 2001, Draft articles on Responsibility of States for Internationally Wrongful Acts.

Yearbook of International Law Commission 2011, Draft articles on the Responsibility of International Organizations. 


\section{TABLE OF CASES- INTERNATIONAL AND NATION-}

AL

Admission of a State to the United Nations (Charter, Art. 4), Advisory Opinion: I.C.J. Reports 1948.

Application of the Interim Accord of 13 September 1995 (the former Yugoslav Republic of Macedonia v. Greece)- Judgment of 5 December 2011

Certain expenses of the United Nations (Article 17, para. 2 of the Charter), Advisory Opinion, I.C.J. Reports 1962.

Competence of Assembly regarding admission to the United Nations, Advisory Opinion, I.C.J. Reports 1950.

Interpretation of the Agreement of 25 March 1951 between the WHO and Egypt, Advisory Opinion, I.C.J Report 1980.

The Antelope, 23 U.S. 66 (1825). 


\section{CURRICULUM VITAE}

Ardit Memeti was born on 25 March 1979. In 2003 he obtained a degree in Law from the University of St. Cyril \& Methodius, Skopje, Macedonia and in 2005 an LLM in International and Comparative Law from the University of Pittsburgh, Pennsylvania which he pursued as a Ron Brown Fellow of the US State Department. During 2006 and 2007 he was awarded the Open Society Institute Fellowship for Returning Scholars. In 2007 he was admitted to the BAR of the R. Macedonia. During the period 2008-2013 he was awarded a NUFFIC scholarship through the Netherlands Fellowship Programme of the Ministry of Foreign Affairs to pursue his PhD studies at the Faculty of Law of Maastricht University in the Netherlands.

Since 2006 he has worked as Assistant Professor at the Faculty of Law of South East European University in Tetovo, R. Macedonia, teaching courses in the field of international and comparative law. During the time period 2002-2004, Ardit Memeti worked as the Parliamentary Program Coordinator for the NDI-National Democratic Institute for International Affairs and as a Rule of Law Officer for the OSCE- Organization for Security and Cooperation in Europe.

Ardit Memeti has also worked as a legal consultant in the area of rule of law for the European Agency for Reconstruction, UNHCR, OSCE, UNDP, UNICEF, European Commission and USAID. 